Nádia Nelziza Lovera de Florentino

Patrícia Helena dos Santos Carneiro

Reny Gomes Maldonado

Rosinete Vasconcelos Costa

(Organizadoras)

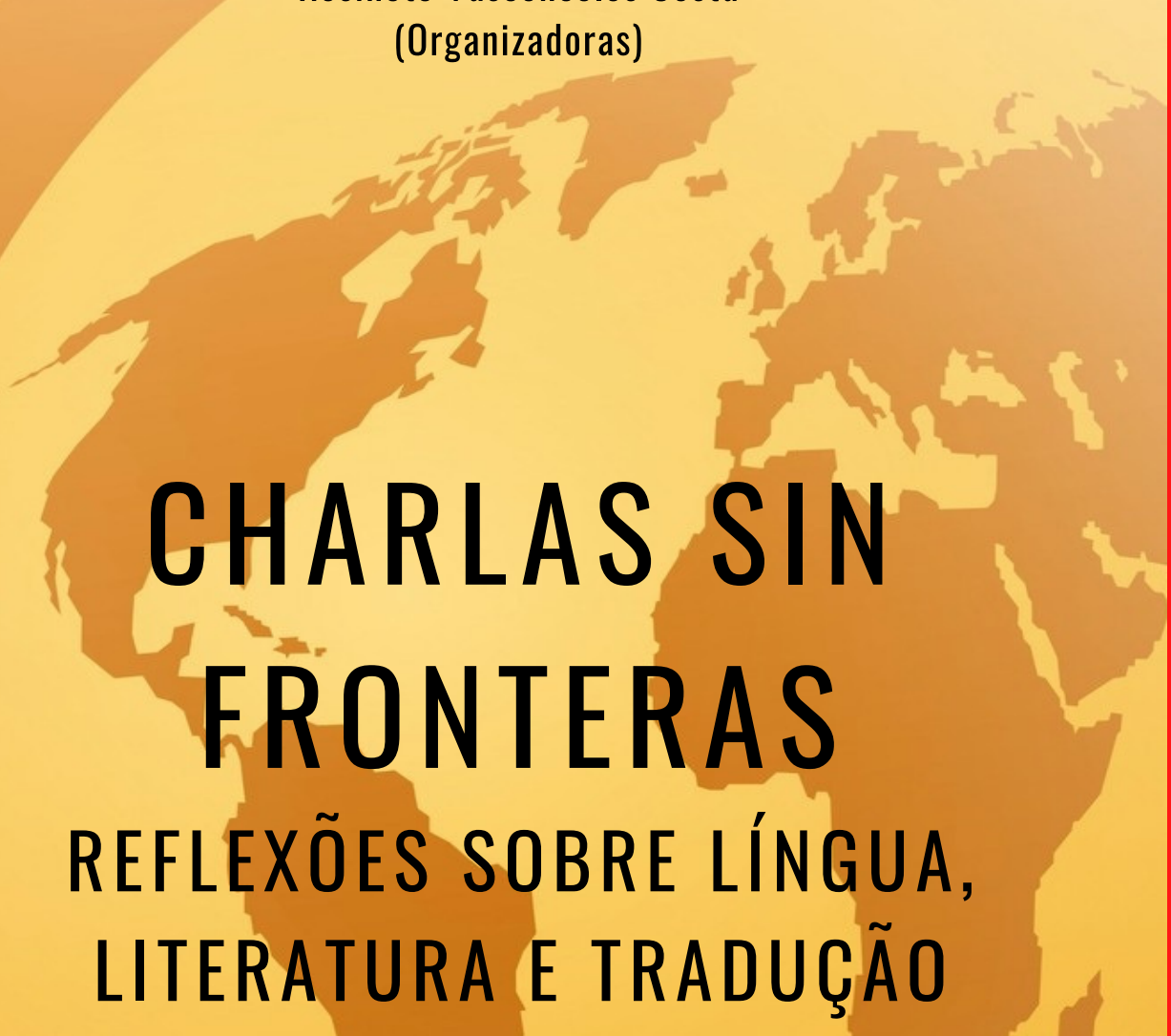

Coleção Pós-Graduação da UNIR

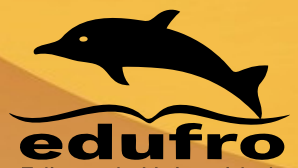

Editora da Universidade

Federal de Rondônia 


\section{CHARLAS SIN FRONTERAS Reflexões Sobre Língua, Literatura e Tradução}

Nádia Nelziza Lovera de Florentino

Patrícia Helena dos Santos Carneiro

Reny Gomes Maldonado

Rosinete Vasconcelos Costa

(Organizadoras) 
FUNDAÇÃO UNIVERSIDADE FEDERAL DE RONDÔNIA

Reitora Marcele Regina Nogueira Pereira

Vice-Reitor José Juliano Cedaro

EDITORA DA UNIVERSIDADE FEDERAL DE RONDÔNIA

\section{CONSELHO EDITORIAL}

Presidente Lou-Ann Kleppa

Ariana Boaventura Pereira

Carlos Alexandre Trubiliano

Eliane Gemaque Gomes Barros

Gean Carla Silva Sganderla

Leandro Soares Moreira Dill

Márcio Secco

Marli Lúcia Tonatto Zibetti

Pedro Ivo Silveira Andretta

Ricardo Gilson da Costa Silva

Xênia de Castro Barbosa

\author{
COMISSÃO CIENTÍFICA \\ Marília Lima Pimentel Cotinguiba \\ Carlos André da Silva Müller \\ Gabriel Eduardo Melim Ferreira \\ Wanderley Rodrigues Bastos \\ João Paulo Assis Gobo \\ Patrícia Goulart Tondineli \\ Lucas Martins Gama Khalil \\ Quesler Fagundes Camargo \\ Estevão Rafael Fernandes \\ Élcio Aloísio Fragoso
}

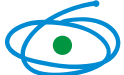

CAPES

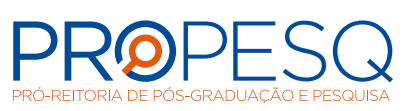

Editora Filiada

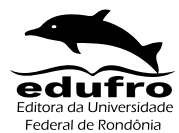

Federal de Rondônia

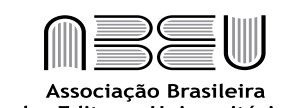

das Editoras Universitárias

Edufro - Editora da Universidade Federal de Rondônia

BR 364, Km 9,5

Campus Unir

76801-059 - Porto Velho - RO

Tel.: (69) 2182-2175

www.edufro.unir.br

edufro@unir.br 


\section{CHARLAS SIN FRONTERAS Reflexões Sobre Língua, Literatura e Tradução}

Nádia Nelziza Lovera de Florentino

Patrícia Helena dos Santos Carneiro

Reny Gomes Maldonado

Rosinete Vasconcelos Costa

(Organizadoras)

Coleção Pós-Graduação da UNIR

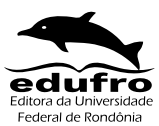

Porto Velho - RO 
(C) 2021 by Nádia Nelziza Lovera de Florentino, Patrícia Helena dos Santos Carneiro,

Reny Gomes Maldonado, Rosinete Vasconcelos Costa (Organizadoras)

Esta obra é publicada sob a Licença Creative Commons Atribuição-Não

Comercial 4.0 Internacional.

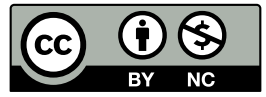

Capa:

Rosivan Diagramação \& Artes Gráficas

\author{
Revisão: \\ Marília Lima Pimentel Cotinguiba
}

Projeto gráfico:

Edufro - Editora da Universidade Federal de Rondônia

Diagramação:

Rosivan Diagramação \& Artes Gráficas

Dados Internacionais de Catalogação na Publicação

Fundação Universidade Federal de Rondônia (UNIR)

Ficha Catalográfica elaborada pela Biblioteca Central da UNIR

F981 Fundação Universidade Federal de Rondônia.

Charlas sin fronteras: reflexões sobre língua, literatura e tradução / organização Nádia Nelziza Lovera de Florentino, Patrícia Helena dos Santos Carneiro, Reny Gomes Maldonado e Rosinete Vasconcelos Costa. - Porto Velho, RO: Coleção Pós-Graduação da UNIR- EDUFRO, 2021.

262 p.; il.

ISBN: 978-65-87539-50-8 (digital)

1. Literatura. 2. Linguística. 3. Português - Imigrantes. 4. Linguagem - Ensino. 5. Covid. I. Florentino, Nádia Nelziza Lovera de. II. Carneiro, Patrícia Helena dos Santos. III. Maldonado, Reny Gomes. IV. Costa, Rosinete Vasconcelos. V. Fundação Universidade Federal de Rondônia.

CDU 811.134 


\section{Sumário}

8 CONSTRUINDO DIÁLOGOS PARA ROMPER AS FRONTEIRAS: UM OLHAR SOBRE OS TEMAS DE LÍNGUA, LITERATURA E TRADUÇÃO

13 CAPÍTULO 1. GUARANI E ESPANHOL: REFLEXÕES HISTÓRICAS, SOCIAIS E CULTURAIS NO CONTEXTO LINGUÍSTICO PARAGUAIO Nádia Nelziza Lovera de Florentino

30 CAPÍTULO 2. UM RETORNO ÀS HUMANIDADES PELA LITERATURA: O DIÁLOGO SEM FRONTEIRAS ENTRE A AMÉRICA LATINAE OBRASIL

Patrícia Helena dos Santos Carneiro Júlio César Barreto Rocha

49 CAPÍTULO 3. CONTEXTO DA LIVE DIFICULTADES Y PROPUESTAS METODOLÓGICAS: REFLEXIONES ACERCA DE LA ENSEÑANZA DE ELE PARA BRASILEÑOS

Elton Emanuel Brito Cavalcante

67 CAPÍTULO 4. A IMPORTÂNCIA DA LITERATURA NAS AULAS DE E/LE

Samuel Anderson de Oliveira Lima

84 CAPÍTULO 5. REFLEXÕES ACERCA DAS LIVES OFERTADAS SOBRE TRADUÇÃO NO CHARLAS SIN FRONTERAS: NECESSIDADE, PERSPECTIVAS E/OU EXPECTATIVAS

Mirella Nunes Giracca

103 CAPÍTULO 6. TODOS CONTRA D@NTE, DE LUÍS DILL: LITERATURA INFANTIL NO CONTEXTO DAS NOVAS TECNOLOGIAS

Liliane Lenz dos Santos

Aroldo José Abreu Pinto 
119 CAPÍTULO 7. A OFERTA DA LÍNGUA ESPANHOLA EM ESCOLAS DA REDE PÚBLICA ESTADUAL DE ENSINO DA CIDADE DE PORTO VELHO-RO

Tiago Carvalho Da Silva

Luciana Pitwak Machado Silva Prates

137 CAPÍTULO 8. REESCRITAS DO EU MÚLTIPLO NOS DIÁRIOS DE ALEJANDRA PIZARNIK

Gracielle Marques

Erlândia Ribeiro da Silva

157 CAPÍTULO 9. ANALISIS Y CONSIDERACIONES DE UNA DE LAS PONENCIAS DEL EVENTO CHARLAS SIN FRONTERAS - LIVE 2: "DIFICULTADES Y PROPUESTAS METODOLOGICAS: REFLEXIONES ACERCA DE LA ENSEÑANZA DEL ESPAÑOL COMO LENGUA EXTRANJERA PARA BRASILEÑOS"

Mariela Magali Román Gutiérrez

178 CAPÍTULO 10. SOB O CRITÉRIO DA FALTA

Ademir Junior de Souza Pires

João Carlos Pereira Coqueiro

Helio Rodrigues da Rocha

195 CAPÍTULO 11. PORTUGUÊS PARA IMIGRANTES: REFLEXÕES NO CONTEXTO DA COVID-19

Odete Burgeile

Djenane Alves dos Santos

Renata Aparecida lanesko

215 CAPÍTULO 12. LA ENSEÑANZA DE ESPAÑOL CON FINES ESPECÍFICOS PARA LUSOHABLANTES: DESAFÍOS DOCENTES $Y$ NUEVAS PERSPECTIVAS

Juan Hernández-Ortega

Reny Gomes Maldonado 
231 CAPÍTULO 13. OLHAR FONÉTICO-FONOLÓGICO NO DIALETO CAMBA E COLLA NA FRONTEIRA BOLIVIA-RONDÔNIA Rosinete Vasconcelos Costa

257 SOBRE OS AUTORES (AS) 


\section{CONSTRUINDO DIÁLOGOS PARA ROMPER AS FRON- TEIRAS: UM OLHAR SOBRE OS TEMAS DE LÍNGUA, LITERATURA E TRADUÇÃO}

No ano de 2020, a pandemia nos silenciou algumas certezas e nos empurrou a uma realidade de distanciamento social e o contato com o mundo passou a ser mais virtualizado. Neste contexto, muitas universidades se reinventaram para manter o diálogo com os seus alunos e com a sociedade rompendo a ausência da presencialidade nas salas de aulas. O desafio era abertura de espaço de conhecimento diversificado ao alunado e ao mesmo tempo nutrir com o apoio emocional discentes e docentes.

Diz o ditado: "dá-me limões e farei uma limonada". Foi essa a ideia de construção de espaço de conhecimento dialogado que ocorreu no seio do Núcleo Docente Estruturante do Curso de Letras-Espanhol avançando a proposta do Projeto de Extensão Charlas sin Fronteras, conduzido depois pelas Professoras Mirela Nunes Giracca, Juliana Bevilacqua Maioli e Reny Gomes Maldonado.

Assim, o curso de Letras Espanhol da Universidade Federal de Rondônia, por meio do Programa de Extensão "Trânsitos, Fronteiras, Migração e Línguas Adicionais na Amazônia”, ofereceu entre os meses de junho a dezembro aos discentes, docentes e comunidade em geral o projeto CHARLAS SIN FRONTERAS na modalidade online, gratuita e com emissão de certificados via Pró-Reitoria.

A proposta inicial do projeto foram lives realizadas via plataforma GoogleMeet, com o objetivo de promover conversas sobre diferentes temas relativos à Língua Espanhola e às culturas dos países hispanofalantes, com vistas a geração de conteúdos que contribuam tanto para a difusão da importância desse idioma no mundo contemporâneo, quanto para o processo de formação de professores de E/LE.

O objetivo era a criação de um canal de diálogo entre a comunidade acadêmica da UNIR - professores, alunos e técnicos - e outros convidados externos, brasileiros e estrangeiros. Este objetivo permanece no nosso horizon- 
te. Em consonância com o movimento de internacionalização da UNIR, essa ação, dada a sua natureza online, buscou alcançar a um amplo público-alvo, sendo destinada a todos que tenham interesse pela Língua Espanhola, em especial, os estudantes dos cursos de Letras, docentes, pesquisadores e outros profissionais que tenham esse idioma como objeto de trabalho, de qualquer parte do Brasil e/ou do mundo.

Nesse sentido, é com satisfação que apresentamos o livro Charlas sin Fronteras: reflexôes sobre lingua, literatura e tradução, que abriga trabalhos oriundos tanto das diferentes lives realizadas durante os meses de junho a dezembro de 2020, como também recebeu trabalhos que dialoguem com os sistemas de língua, literatura e tradução colaborando para ampliação de questões expostas no referido evento.

Este livro é uma publicação fruto de uma parceria entre o Departamento de Línguas Estrangeiras (DALE) e o Mestrado em Letras, da Universidade Federal de Rondônia, tendo este último financiado esta coletânea que vem à luz reunindo produção significativa e de caráter interdisciplinar.

No primeiro capítulo "Guarani e Espanhol: contatos, convivências e confluências no contexto linguístico paraguaio”, a Professora Nádia Nelziza de Florentino analisa a situação linguística do Paraguai. Inicialmente a autora apresenta um panorama da história do Paraguai dando ênfase à questão linguística para em seguida refletir sobre a utilização do guarani, espanhol e do jopará no país.

O segundo capítulo tem como título "Um retorno às humanidades pela literatura: o diálogo sem fronteiras entre a América Latina e o Brasil” e foi escrito pelos professores Patrícia Helena dos Santos Carneiro e Júlio César Barreto Rocha. O texto parte da perspectiva da Cultura, do Direito e da Política Linguística, estatuindo um verdadeiro diálogo sem fronteiras linguísticas. Assim, traça uma aproximação aos estudos das relações entre o Direito e a Literatura como norte, possibilitando compreender a realidade social e jurídica, num diálogo interdisciplinar.

Com o capítulo "Contexto da live dificultades y propuestas metodológicas: reflexiones acerca de la enseñanza de ele para brasileños”, o Professor Elton Emanuel Brito Cavalcante propõe uma análise da live "Dificultades y propuestas metodológicas: reflexiones acerca de la enseñanza de ELE para 
brasileños", cujo objetivo foi refletir acerca das principais dificuldades enfrentadas pelos brasileiros durante o aprendizado da língua espanhola.

Tendo em vista que o ensino de literatura nas aulas de espanhol como língua estrangeira tem sido negligenciado, muitas vezes, ocasionado pela forma como se estruturam as normativas em cada Estado, no capítulo quatro, "A importância da literatura nas aulas de ELE”, o professor Samuel Anderson de Oliveira Lima reflete sobre o papel importante que a literatura tem para a educação e formação do estudante da educação básica, em especial nas aulas de espanhol como língua estrangeira.

No quinto capítulo, "Reflexões acerca das lives ofertadas sobre tradução no Charlas sin Fronteras: necessidade, perspectivas e/ou expectativas”, a professora Mirella Nunes Giracca apresenta uma análise sobre a importância de eventos que ofereçam temas direcionados aos Estudos da Tradução em suas mais diversas essências. Primeiramente foram apresentadas as lives que trataram sobre tradução para, em seguida, serem apresentados os conteúdos explanados pelos palestrantes responsáveis, refletindo sobre como os Estudos da Tradução podem ser direcionados a partir de diferentes olhares e perspectivas segundo as teorias, os propósitos e as abordagens.

Escrito por Liliane Lenz dos Santos e Aroldo José Abreu Pinto, o sexto capítulo é intitulado “Todos contra D@nte, de Luís Dill: literatura infantil no contexto das novas tecnologias". Os autores apresentam uma leitura da obra Todos contraD@nte, de Luís Dill, a partir de reflexões a respeito do leitor e a literatura infantil e da trajetória da literatura infantil no Brasil.

O sétimo capítulo, intitulado como "A oferta da língua espanhola em escolas da rede pública estadual de ensino da cidade de Porto Velho-RO”, é a contribuição de Tiago Carvalho da Silva e Luciana Pitwak Machado Silva Prates. Este texto tem como objetivo verificar a forma de oferta da língua espanhola nas escolas públicas da rede estadual de ensino da cidade de Porto Velho, no Estado de Rondônia, após a aprovação da Medida Provisória nº 746 (mais tarde convertida na Lei no. 13.415, de16 de fevereiro de 2017), que revogou a Lei Federal nº. 11.161/2005 (Lei do Ensino do Espanhol) e alterou também partes da Lei de Diretrizes e Bases da Educação Nacional (Lei n. 9394/96). Os efeitos da Medida Provisória nº 746 foram sentidos na Resolução 132/06-CEE/RO e Portaria 130/10-GAB/SEDUC, ambas normas do Estado de Rondônia. 
No oitavo capítulo, intitulado "Reescritas do eu múltiplo nos diários de Alejandra Pizarnik”, Gracielle Marques e Erlândia Ribeiro da Silva investigam, a princípio, os protocolos da escrita diarística, pertencente aos gêneros confessionais, que acolhe a inscrição da singularidade do seu autor e suas extravagâncias textuais. São analisados no texto os mecanismos da reescrita do "eu" nos quais se inscreve o jogo das máscaras da personalidade pizarnikiana como uma estratégia que confirma sua consciência de criar um diário de escritora, nos quais os dilemas existenciais se fundem com os estéticos.

A Professora Mariela Magali Roman Gutierrez foi a responsável pelo nono capítulo, intitulado "Analisis y consideraciones de una de las ponencias del evento charlas sin fronteras - live 2: "Dificultades y propuestas metodologicas: reflexiones acerca de la enseñanza del español como lengua extranjera para brasileños". O objetivo do texto é uma exposição de conhecimentos e experiências sobre o ensino de língua espanhola para estrangeiros especialmente no que se refere às dificuldades encontradas pelos brasileiros na aprendizagem do idioma.

Os pesquisadores Ademir Junior de Souza Pires, João Carlos Pereira Coqueiro e Hélio Rodrigues da Rocha escreveram o texto "Sob o critério da falta”, que se constitui como o décimo capítulo desta coletânea. O objetivo dos autores é apresentar o capítulo XIX do relato de Grubb, que foi publicado em Londres pela Editora Seely, Service \& Co. Limited em 1911, examinando o discurso grubbiano sobre o sistema econômico dos lengua-maskóy.

No décimo primeiro capítulo, intitulado "Português para imigrantes: reflexões no contexto da COVID 19", Odete Burgeile, Djenane Alves dos Santos e Renata Aparecida Ianesko descrevem as atividades realizadas no curso de Português como Língua Adicional, que faz parte do programa de extensão denominado Trânsitos, fronteiras, migração e línguas adicionais na Amazônia. O objetivo foi promover ações realizadas no curso sobre as fake news (notícias falsas), que fazem parte dos temas transversais como saúde, ética e cidadania, visando conscientizar os alunos e, assim, minimizar a propagação do coronavírus por meio da identificação de informações falsas e reflexão de suas consequências.

O artigo "La enseñanza del español con fines específicos para lusohablantes: desafíos docentes y nuevas perspectivas", que constitui o décimo segundo capítulo, oferece um panorama sobre o papel do ensino do espanhol com fins específicos sob a perspectiva contrastiva do espanhol/português. 
Também apresenta um esboço teórico, revisando a terminologia de ELE e EFE na linguística aplicada, oferecendo indicações para planejamento de cursos de EFE para lusofalante e orientação bibliográfica de principais manuais publicados para futuras pesquisas na área de Letras.

No último capítulo, "Olhar fonético-fonológico no dialeto camba e colla na fronteira Bolivia-Rondônia”, Rosinete Vasconcelos Costa mostra o modo peculiar do espanhol falado em Guayaramerín, levando em conta tanto os fatores linguísticos quanto extralinguísticos responsáveis pela variação na fala, ou seja, um quadro que represente linguisticamente essa comunidade de fala por meio dos processos fonético-fonológicos.

Contemporâneas, mesmo que ditas na década de 1980, são as palavras de Darcy Ribeiro, em Universidade Para quê? (1986), quando do debate sobre Educação Superior: "A universidade de que precisamos antes de existir como um fato no mundo das coisas, deve existir como um projeto, uma utopia no mundo das ideias”. Ademais disto, pregava Darcy Ribeiro que a Universidade deveria ter "a objetividade necessária para ser um plano orientador dos passos concretos pelos quais passaremos da Universidade atual para a Universidade Necessária”.

É neste espírito da Universidade como centro de debate de ideias e de alargamento de horizontes acadêmicos, humanos e científicos, que esta obra coletiva reúne pesquisadores para pensar Língua, Literatura e Tradução, permitindo quebrantar barreiras ao estabelecer um diálogo fundamentado na $\mathrm{Ci}^{-}$ ência, no Estudo entre pesquisadores brasileiros e estrangeiros.

Por fim, esperamos que a leitura destas contribuições seja proveitosa e agregadora para toda pessoa que queira conhecer um pouco mais dos temas que nos congregam nas Letras e nas Humanidades.

Nádia Nelziza Lovera de Florentino Patrícia Helena dos Santos Carneiro Reny Gomes Maldonado Rosinete Vasconcelos Costa 


\section{CAPÍTULO 1. GUARANI E ESPANHOL: REFLEXÕES HIS- TÓRICAS, SOCIAIS E CULTURAIS NO CONTEXTO LIN- GUÍSTICO PARAGUAIO}

Nádia Nelziza Lovera de Florentino

\section{Introdução}

Este artigo surge a partir das reflexões propostas na live "Las variedades del español en Latinoamérica: Paraguay y Venezuela”, em que foram apresentadas as diferenças culturais, linguísticas e sócio-históricas entre Paraguai e Venezuela. A principal motivação surgiu da constatação de que, apesar de possuir uma extensa região de fronteira e proximidade históricas e culturais com o Brasil, o Paraguai ainda permanece praticamente desconhecido para uma boa parcela dos brasileiros, especialmente na região Norte, em que a proximidade maior é com a Bolívia.

O objetivo deste trabalho é, portanto, apresentar algumas considerações a respeito da situação linguística do Paraguai, especialmente no que se refere à convivência entre espanhol e guarani no país. Para tanto, é apresentado primeiramente um breve panorama da história linguística do Paraguai para posteriormente refletir-se sobre a situação atual das línguas faladas no país.

Como procedimento metodológico foi utilizada a pesquisa bibliográfica, amparada em autores como Meliá (1997; 2011), Lustig (1996), Plá (1970), dentre outros.

Por fim, espera-se que as reflexões aqui propostas permitam uma aproximação ao universo linguístico paraguaio e se constituam como ponto de partida para futuros trabalhos sobre o tema.

\section{Breve panorama da história linguística do Paraguai.}

Ao iniciar seu estudo a respeito da história do Paraguai, Efraim Cardozo (2009) descreve o que ele denomina de "culturas primitivas" e afirma 
que a região que hoje pertence ao Paraguai era habitada pelos guaranis, o que marcou profundamente a formação da nacionalidade paraguaia:

La región oriental estaba principalmente habitada por guaraníes, que desempeñaron un papel fundamental en la formación de la nacionalidad paraguaya, por su estrecha alianza con los españoles. Agricultores, sedentarios, no estaban organizados en un solo cuerpo político, pero integraron una vasta comunidad cultural que se extendía discontinuamente por casi todo el territorio sudamericano, desde las Antillas hasta el Río de la Plata, entre los primeros contrafuertes andinos y las costas del Atlántico, y en el interior a lo largo de los grandes ríos y de las vías terrestres de comunicación. (Cardozo, 2009, p. 8-9)

Como podemos observar na citação de Cardozo, a falta de organização política e sua natureza voltada à agricultura fizeram com que os guaranis estabelecessem uma vida em comunidade e se aliassem aos espanhóis que chegavam à região. Certamente isso fez com que a questão linguística no Paraguai fosse marcada pelo convívio marcante entre o guarani, língua que já era falada pelos habitantes originais e o espanhol, trazido pelos europeus.

A respeito do sistema linguístico utilizado nos primórdios da conquista espanhola, Cardozo (2009) prossegue apontando para a importância da língua guarani não apenas para os habitantes da região em que se estabeleceu o Paraguai, mas também para todo o conjunto de povos originários que habitavam a região sul do continente americano:

Su gran patrimonio cultural era la lengua, de la que estaban orgullosos [...]. Fue el francés de la antiguedad americana, la "lengua general", mediante la cual se entendian todas las tribus cuyos dialectos eran intraducibles entre sí,y el principal instrumento de penetración de conquistadores y misioneros en el heterogéneo y complicado mundo étnico americano (Cardozo, 2009).

Nessa perspectiva, o guarani era motivo de orgulho para os seus falantes nativos e também se constituiu como base para uma espécie de pidgin ou língua geral através do qual diversos povos se comunicavam entre si e tam- 
bém como instrumentos para que conquistadores e missionários conseguissem adentrar aos territórios dominados por diversos povos e estabelecerem-se neles. Assim, por ter tamanha importância tanto para seus falantes quanto para os conquistadores, o guarani se manteve no universo cultural paraguaio, influenciando e sendo influenciado pelo espanhol trazido da Europa.

Maria de los Angeles Mateo del Pino (1993) no texto La creación del lenguaje em la mitología guarani, também corrobora com a importância do guarani para o povo que habitava a região paraguaia antes da conquista. O guarani é apontado pela autora como uma herança dos povos autóctones, um patrimônio cultural: "La cultura primitiva que habitaba la región Oriental del Paraguay era la lengua guaraní. El legado más vivo de los antepasados autóctonos es, sin duda, el idioma. Su gran patrimonio cultural era la lengua” (Mateo Del Pino, 1993, p. 45)

Ao continuar seu texto sobre os guaranis, Mateo del Pino (1993) destaca a importância da tradição oral para a propagação da memória e da cultura desse povo, que possuía um rico legado literário ainda que não tivessem conhecimento da escrita. Nas palavras da autora, "a pesar de que esta comunidad desconocía la escritura, esto no supone carencia de literatura, puesto que la tradición oral era suficiente para transmitir la memoria colectiva del pueblo, alimentando la índole poética de los guaraníes”. (Mateo Del Pino, 1993, p. 45).

Meliá (1997, p. 18) aponta que existia uma unidade linguística antes da chegada dos espanhóis, uma vez que, salvo algumas pequenas diferenças, todos falavam a mesma língua. Além disso, entre os viajantes europeus havia muitos que conheciam o Guarani por já terem convivido nas aldeias em situações adversas como naufrágios. Esse conhecimento da língua facilitava os primeiros contatos, o que poderia ser mais difícil com outras línguas.

A língua guarani permaneceu como patrimônio cultural do povo guarani durante séculos. $\mathrm{O}$ fato de ser utilizado como base para uma língua geral certamente proporcionou inúmeros contatos linguísticos e mudanças advindas desse contato. Porém, uma grande transformação social, econômica e cultural ainda estava por vir, acompanhada dos europeus que chegavam cada vez em maior número à América. 
Em linhas gerais, a entrada de europeus no território paraguaio se deu primeiramente com o explorador Alejo García, em 1525. Alguns anos depois, Sebastian Gaboto também chegou à região, partindo em pouco tempo, após entrar em confronto com os habitantes originários da região. A expedição que realmente teve sucesso na entrada a esse território foi a de Pedro de Mendoza. De acordo com Mérida (1973)

La primera expedición que penetró con relativo éxito en territorio de la cuenca del Plata fue la del adelantado don Pedro de Mendoza, en la que se perseguía, además de establecer en aquella región una cabeza de puente con el Alto Perú, ganarle la mano a los portugueses em la conquista de aquellas tierras y procurar que el Tratado de Tordesillas fuese respetado. (Merida, 1973, p.4).

Meliá (1997) caracteriza o encontro entre espanhóis e guaranis como um "Campo de tradução":

La entrada de esos nuevos karaí y la aventura semántica de esta denominación muestra hasta qué punto dos sociedades en contato llegan a encontrarse en un campo de traducción posible en el que cada uno se dice a su modo, ideologiza lo que entiende o piensa entender del outro y eventualmente procura sacar provecho de essa traducción. Que la traducción se vuelva traición es también una posibilidad de donde derivan tantas ambigüedades, malentendidos y hasta agresiones (Meliá, 1997, p. 7)

A partir dessa citação, pode-se entender que nesse ambiente de colonização, tanto os conquistadores quanto os povos que já habitavam a região paraguaia estabeleceram trocas e diálogos entrecortados pelas ideologias. Isso proporcionou transformações econômicas sociais e culturais dos dois lados e claramente inúmeros mal entendidos e agressões, sem mencionar as inúmeras vezes em que essas traduções serviram como ponto de partida para que um povo tirasse proveito do outro nas mais variadas situações.

Neste ponto, há que se considerar que em terras paraguaias a exploração espanhola não foi tão intensa como a que ocorreu, por exemplo, no Brasil. Isso 
porque os espanhóis não encontraram abundância de metais preciosos como em outras regiões, o que tornou a região menos interessante para exploração. A respeito disso, Báez e O’leary explicam:

No existiendo minas de metales preciosos en el Paraguay, muy pocos españoles se establecieron en él. En su mayoría eran tenderos o pulperos, los que habitaban la Asunción. Otros se hacían conceder tierras según el sistema de la encomienda; outros se hacían otorgar - con el nombre de merced real - extensas dehesas de labor y pasto para dedicarse a la ganadería. (Báez; O’leary, 2008, p. 141)

Assim, não sendo interessante a exploração de metais preciosos, a região passou a se constituir como ponto de passagem e os que se estabeleciam por ali se dedicavam ao comércio de produtos comestíveis e suprimentos e posteriormente à criação do gado. Tal fato certamente contribuiu para que espanhol e guarani convivessem de forma tranquila, uma vez que proliferavam os mestiços, que dominavam a língua do pai espanhol e da mãe guarani. Estima-se que em 1788 o Paraguai contava com uma população de aproximadamente noventa e seis mil crioulos e apenas duzentos e cinquenta espanhóis (Báez; O’leary, 2008).

Para Mérida (1973) o convívio pacífico e a miscigenação propiciaram transformações sociais, culturais e econômicas tanto na vida dos europeus quanto dos habitantes originais e especialmente naqueles nascidos entre as duas culturas. Para o estudioso, até mesmo o conceito de família ganhou novos significados e atribuições:

La família, por ejemplo, tanto la indígena como la española, adquirió un significado muy diferente al que tenía en ambos grupos solamente unos años antes. Para los españoles ya no incluiría el concepto de família únicamente a aquellos que viven en un hogar comum bajo ciertos lazos de consanguinidad, matrimonio o servicio, pues el diverso comportamiento sexual e incluso religioso, al intercambiarse, traería nuevos módulos em las sociedad hispano-indígena paraguaya tanto en la ideología como en la conducta (Merida, 1973, p. 5-6). 
Nesse sentido, se pensarmos nos contatos linguísticos presentes na região, podemos estender essas transformações sociais e culturais às línguas faladas, que também sofreram transformações não apenas advindas de questões temporais e locais.

Mateo del Pino caracteriza as transformações ocorridas nesse período da seguinte forma:

Con la implantación del poder español, y la difusión de las prácticas de vida y de los conocimientos europeos, se produce una honda transformación en las costumbres y en la situación de los aborígenes. Una estructura social, política, económica y cultural se quiebra, para dar lugar a outra, importada por los conquistadores (Mateo Del Pino, 1993, p. 46).

A nova estrutura nos costumes e na cultura aborígene tanto na implantação do poder espanhol quanto à sua maneira de viver, propagadas na colônia, deram origem a um novo modelo social, cultural, político e econômico. Conforme já anunciado, tais transformações também impactaram as línguas utilizadas tanto pelos conquistadores quanto pelos guaranis.

Outro ponto importante a se considerar a respeito dessa nova estrutura social e cultural paraguaia é presença da mulher no período colonial. Para Meliá (1997), a união dos "cristãos" com as mulheres guaranis foi um elemento característico do processo de colonização do Paraguai. Nas palavras do teórico,

Fue también característico del proceso colonial paraguayo el modo de unión de los "cristianos" con las mujeres de los Guaraní, lo que muy pronto, ya en el mismo siglo XVI, daba lugar a justificaciones ideológicas contrapuestas; se hablaba de "cuñadazgo", como si entre "cristianos" e indios se hubiera sistematizado una relación de verdadero parentesco pero también se denunciaba la "saca de mujeres" [...] "trueque de mujeres", como si la mujer guaraní fuera tratada solamente como "pieza” esclava. Más aun, se puede preguntar si el tan comentado "paraíso de Mahoma" no era en realidad una sutil práctica de genocidio, destinada a acabar con los indios, como de hecho sucedió (Meliá, 1997, p. 20-21) 
Assim como em outras regiões americanas, a mulher guarani foi tida como objeto de satisfação sexual e como instrumento de dominação, a fim de forjar uma ideia de parentesco. Através do estupro, a escravidão e o genocídio indígena foram levados a cabo pelos europeus. A mestiçagem também era um instrumento de dominação. Para Mateo del Pino (1993), a união do homem espanhol e da mulher indígena se tornou um verdadeiro "amálgama" da cultura paraguaia:

La amalgama de la cultura guaraní y la hispana se debió a la fusión del hombre español y la mujer indígena, generalmente, guaraní. Los indígenas aportaron la tierra y sus imensos recursos, algunos valores de su agricultura, sus conocimientos botánicos y, muy especialmente, su idioma. El legado más vivo y característico de los antepasados autóctonos es, sin duda, el idioma; nada tan identificado con la idiosincrasia, con la autenticidad nacional, con la peculiaridad del ser paraguayo (Mateo del Pino, 1993, p. 46)

De acordo com a autora, com a fusão de culturas, através da união entre homem espanhol e mulher guarani, os conhecimentos guaranis foram transmitidos às gerações seguintes e, principalmente, fizeram com que o idioma guarani fosse perpetuado como legado e marcasse a identidade paraguaia.

Para Josefina Pla (1970), a escassez de metais preciosos, que fez com que a base da economia fosse essencialmente a agropecuária, e a ausência da mulher branca na sociedade colonial paraguaia foram fatores determinante para a mestiçagem. Além disso a falta de contato com o exterior e a necessidade de sobrevivência fizeram com que a união com as mulheres indígenas fosse um fator decisivo. Imperava, então, a poligamia:

Esto dio como resultado que no sólo durante el período más acusado de ausencia de mujer blanca (1537-1555) sino también después, durante mucho tiempo, imperase como institución generalizada una poligamia sui generis, de la cual el primero en dejar constancia documentada fue el Gobernador Domingo Martínez de Irala y acerca de cuyas proyecciones sociales es más que elocuente su testamento. Cada alianza con el aborigen se traducía en el ingreso de nuevas mujeres en la casa del colono. Bajo el techo de éste, esas mujeres se cristianizaban, y a la vez que recibían del jefe del hogar protec- 
ción y blando trato, trabajaban para él en la casa y en su huerta o chacra. Esto último no debe extrañar, ya que entre los indígenas era la mujer la encargada de cultivar la tierra, tejer lienzos y esteras, fabricar la cerámica de uso cotidiano. Esas mujeres constituyeron el a todas luces peculiar harén del colono, fuertemente coloreado, como se ve, por los conceptos locales en cuanto a la división del trabajo, que por cierto perduran en parte hasta hoy. En 1545 había ya 600 mestizos; en 1570 la población española ascendía a 300 vecinos, y se contaban 2.900 criollos o hijos de español y española; la cifra disminuyó enormemente luego de dar Asunción nacimiento a ocho ciudades. A fines de siglo, desangrada Asunción en fundaciones, sólo se contaban 200 hombres y más de dos mil mujeres; fue cuando Barco de Centenera llamó a Asunción « paraíso de Mahoma ». Los hijos habidos por el conquistador en estas mujeres guaraníes, fueron los llamados « mancebos de la tierra », cuyo número en 1570 había duplicado ya el de españoles criollos. Una disposición real, mirando por la estabilidad de la colonia, dio a estos mancebos status idéntico al del español; eran demasiado pocos éstos en aquella tierra olvidada de Dios y también de la Corona, que sin embargo necesitaba de ellos para que la defendiesen. (Pla, 1970, p. 8).

Como pode ser vislumbrado na citação, as mulheres guaranis constituíam a maior parte da população e foram aos poucos se convertendo ao cristianismo. Delas foram nascendo os mestiços, denominados de "mancebos da terra" e que receberam da coroa espanhola reconhecimento, na medida em que eram importantes para a dominação espanhola e para a proteção da terra.

No que se refere às raízes culturais dos mancebos da terra, pode-se afirmar que o elemento ancestral indígena esteve fortemente presente, na medida em que era a mãe guarani a responsável direta pela criação dos filhos:

El español, eje humano de esta situación un tanto musulmana, no presta atención al hijo varón así habido sino al llegar éste a la edad en que se manifiestan las cualidades que lo pueden erigir en continuador del apellido. En los primeros años, los decisivos, el retoño está enteramente a cargo de la madre india, que por su parte no ha ascendido a un nivel notoriamente diferenciado en lo que a cultura respecta. Aunque catequizada, la mujer indígena permanece anclada en una etapa en que la semántica aborigen do- 
mina las formas mentales y colorea toda noción adquirida. Para el mestizo, pues, el padre se proyecta a distancia, temido más que amado, emulado en su poder, resistido íntimamente en su disciplina; secretamente despreciado, sobre todo, por su ignorancia de las claves terrales. Aunque el español domine con su técnica este ámbito, nunca cesará de ser en él un postulante en el umbral irrebasado de los misterios naturales, que constituyen el mundo peculiar del mestizo y su ascendencia materna. El mancebo sabe que ante la ley es el igual del padre español; pero esta igualdad ante la ley no compensa el desnivel de cosmovision que los separa. Los años de infancia nutridos plurilateralmente de experiencia materna, corroborada por el trato expansivo con la parentela indígena, así lo determinan. A través no sólo del idioma, sino también de las miradas, de los silencios, las actitudes de sus ascendientes netamente indios, el mancebo crece raigalmente unido a la raza y a la tierra. El asombro cósmico del europeo enfrentado a un mundo nuevo se extingue en la primera generación local.(Pla, 1970, p. 8-9).

Essa proximidade dos mestiços com a terra e com a ancestralidade indígena fez com que as raízes europeias ficassem cada vez mais distantes. Por outro lado, a utilização do guarani nas conversas com a mãe e os irmãos, nas atividades do dia-a-dia e também nas crenças e tradições, foi decisivo para a permanência e subsistência do idioma.

Com a chegada dos jesuítas ao Paraguai e a fundação dos reductos, o guarani ganha uma nova condição, uma vez que os padres da Companhia de Jesus faziam questão de que se falasse apenas a língua indígena e também foram responsáveis por descrever a língua. Os jesuítas se dirigiam aos índios apenas em guarani e fizeram com que a língua permanecesse isolada das demais nos locais em que viviam (PLA, 1970). É dessa época a primeira gramática da língua guarani denominada Arte, vocabulario, tesoro y catecismo de la lengua guarani, publicada em 1640 pelo padre Antonio Ruiz de Montoya.

1 Nos anos 1993 e 2002 os livros foram preparados e reeditados. Bartomeu Meliá foi o responsável pela edição de 2020. As partes Arte de la lengua guarani e Catecismo de la lengua guarani podem ser encontrados no acervo da Biblioteca Brasiliana Guita e José Mindlin, nos links https://digital.bbm.usp.br/handle/bbm/4901 e https://digital.bbm.usp.br/handle/bbm/4392. 
No século XVIII, os jesuítas são expulsos e os reductos por eles criados são dispersos. Ocorre um rompante econômico e cultural que culminaria na geração responsável pela independência do país, em 1811. De acordo com Josefina Pla (1970):

La desaparición de la competencia jesuítica aparejó un repunte económico que tuvo su paralelo en las comunicaciones culturales; apareció entonces la primera élite de contornos intelectuales definidos. La generación que promovió y llevó a cabo la independencia - en su mayoría una generación pos jesuítica - fue un grupo básicamente compuesto de españoles y criollos de impregnación enciclopedista imbricada en la tradición comunera; su actuación prometía una intensificación del ritmo españolizante, y sus primeras medidas de gobierno son significativas al respecto. (Plá, 1970, p. 16)

Essa nova estrutura social, política e econômica criada pela declaração de independência também impactou nas questões linguísticas e culturais do país. Como pode ser visto na citação de Plá (1970), o grupo que levou a cabo a independência era composto de espanhóis e mestiços, e tinha como frente uma tentativa de modernizar o país e isso incluía manter o espanhol como língua oficial. Para Meliá (2011), apesar de ter sido um evento importante para o país, a independência por si só não alterou as línguas faladas no Paraguai:

Ni las revoluciones más radicales ni los cambios políticos más acentuados logran cambiar automática o repentinamente la lengua de la sociedad donde esos fenómenos históricos se dan. Para el cuadro linguístico del Paraguay, la fecha concreta - digamos el 14 de mayo de 1811 - es irrelevante. Por supuesto, la lengua - las lenguas - que hablaba el día antes de la Independencia la siguiera hablando el día después. La lengua como fenómeno social sólo manifestará sus cambios a largo plazo, si bien es cierto que puede transformarse con mayor rapidez en determinadas circunstancias y con la aplicación de políticas linguísticas definidas (Meliá, 2011, p. 154).

Assim como ocorreu em outros países americanos, a língua europeia foi mantida enquanto as línguas ameríndias, ainda que continuassem a ser faladas pela maioria dos habitantes, passou a ser vista como língua inferior, subjugada. 
Apesar de o guarani continuar sendo a língua falada por todo o povo paraguaio após a independência, segundo Meliá (2011), os escritos nessa língua passaram a ser escassos após a saída dos jesuítas:

Desde el siglo XVII, pero sobre todo em el siglo XVIII, la lengua guaraní desarrolló una abundante literatura dentro de los pueblos o reducciones guaraní-jesuíticas del Paraguay [...] Por extraña paradoja la documentación em guaraní se interrumpe despúes de proclamarse la independencia del Paraguay em 1811, a pesar de que el uso del guaraní siguió siendo del medio de expresión de todo el pueblo paraguayo [...] (Meliá, 2011, p. 153)

Em 1842, o ditador Don Carlos Antonio López iniciou um processo que culminou na expansão da língua espanhola no Paraguai. Ele foi responsável por abolir os regimes indígenas que ainda existiam no país e ordenou a tradução de todos os sobrenomes indígenas ao espanhol. Além disso, Carlos Antonio forneceu amparo para que professores, arquitetos, técnicos imigrassem para o Paraguai e também executou um plano de alfabetização em massa. Com Francisco Solano López e sua esposa Madame Lynch, o progresso político, intelectual e econômico paraguaio assumiu o ápice e a elite paraguaia passou a viver de acordo com um estilo cada vez mais europeizante (Plá, 1970).

Com a Guerra da Tríplice Aliança, parte da população paraguaia foi dizimada, restando, em sua maioria, mulheres e crianças. Após a guerra, o processo de expansão da língua espanhola fica para trás e de certa forma o Paraguai passa a vivenciar o que ocorria nos primórdios da colonização: a educação das crianças passa a ser papel da mulher:

El renovado predominio femenino de la población tuvo sin duda su reflejo en la cultura que surgió de esas ruinas. Por mucho tiempo las nuevas generaciones rurales estuvieron entregadas a la casi total tutela y guía maternas, reproduciendo en cierta medida las ya olvidadas circunstancias de los primeros tiempos coloniales. El idioma guaraní apoyó sin duda en ello una de sus etapas de predominio aunque naturalmente también empobrecido por su desvinculación creciente con las formas más primitivas de la existencia tribal [...] (Plá, 1970, p. 18) 
Essa predominância feminina na população paraguaia e a predominância rural do estilo de vida que se estabeleceu desde então foi decisiva para que o guarani ganhasse força como língua nacional, apesar do espanhol, que ainda mantinha o status de língua oficial (PLÁ, 1970). No período que se segue à Guerra da Tríplice Aliança, o Paraguai enfrenta um período de instabilidade política e econômica, com esforços para retomar a posição anterior à Guerra. $\mathrm{O}$ país enfrenta uma guerra civil e, quase na sequência, Guerra del Chaco contra a Bolívia entre 1932 a 1935. Após a Guerra del Chaco segue-se um período de relativa estabilidade econômica e avanços culturais. Em 1954 Alfredo Stroessner assume o poder, governando o país em regime ditatorial por mais de três décadas (Cardozo, 2009).

Durante o período da ditadura Stroessner, a língua guarani e todos os elementos da cultura indígena passam a ser perseguidos pelas instituições nacionais, sendo proibidos nas escolas e espaços públicos ${ }^{2}$. A língua indígena é vista, então, como algo inferior, que necessita ser combatida para que o cidadão pudesse obter um prestígio social. Essa situação passaria a mudar apenas com a promulgação da Constituição paraguaia de 1992 que em seu artigo 147 caracteriza o Paraguai como um país pluricultural e bilíngue. No referido artigo consta a seguinte redação: “[...] Son idiomas oficiales el castellano y el guaraní. La ley establecerá las modalidades de utilización de uno y otro. Las lenguas indígenas, así como las de otras minorías, forman parte del patrimonio cultural de la Nación" (Paraguay, 1992). Outro ponto importante da constituição encontra-se no artigo 77 , em que preconiza a educação escolar inicial na língua materna do educando, além da obrigatoriedade do ensino da língua guarani, ao lado do espanhol, nas escolas.

O fato de ser elevado a língua oficial certamente foi um fator importante para o reconhecimento do guarani como elemento fundamental para a identidade nacional paraguaia. Porém, quase trinta anos após a promulgação da Constituição, os desafios para se compreender a pluralidade cultural e o bilinguismo paraguaio ainda persistem.

2 Ver, por exemplo, a reportagem Myles McCormick publicada em 2018 no The New York Times. Disponível em https://www.nytimes.com/es/2018/01/08/espanol/america-latina/paraguay-guarani-espanol-lengua-indigena.html 


\section{Considerações sobre a atual situação linguística do Paraguai}

O Paraguai é um dos poucos países da América Latina a ter uma língua indígena como língua oficial. Para Josefina Plá (1970, p. 21), a dualidade cultural e espiritual paraguaia se manifesta pela via do que ela denomina de bilinguismo, duas línguas convivendo: o guarani predominante na zona rural e o espanhol nas cidades:

Por la vía gemela del bilingüismo seguirá sin embargo transitando aún por mucho tiempo la dualidad cultural y espiritual del pueblo paraguayo. El guaraní amparado en la mayoría conservadora, apoyado en la lenta transformación de los estratos culturales inferiores y el predominio de la vida rural; el español, cimentado en esa misma transformación, y en la medida en que es vehículo de una cultura universal en inevitable penetración creciente. La transmutación de la mentalidad regionalista hacia una contemporaneidad de cuño latinoamericano más comunicativo se refleja en la frecuencia y amplitud crecientes de la onda idiomática.

A escritora faz essa descrição em plena década de 1970, realidade anterior à redemocratização. De lá para cá pode-se afirmar que o guarani tem se mantido como língua predominante, em alguns casos como única língua. De acordo com os resultados da pesquisa permanente nos lares paraguaios realizada pelo governo paraguaio ${ }^{3}$, em $2019,38,5 \%$ da população tinha o guarani como única língua, 30,6\% declararam utilizar tanto o espanhol quanto o guarani, 28,5\% declararam utilizar apenas o espanhol e 2,1\% afirmaram utilizar outros idiomas - português, alemão, japonês, inglês, coreano.

Através do resultado desse censo, pode-se constatar que mais da metade da população paraguaia domina o guarani como primeira ou segunda língua. No entanto há que se destacar que a questão geográfica é relevante nessa escolha linguística, uma vez que quanto mais distante o habitante estiver dos grandes centros, mais predominante será o guarani (Lee, 2018, p. 111).

Por outro lado, é preciso esclarecer alguns aspectos a respeito do guarani falado pelos paraguaios, que se modificou graças aos fatores históricos, sociais

3 Dados obtidos na página eletrônica da Dirección General de Estadística, Encuestas y Censos do Paraguay. Disponível em https://www.ine.gov.py/news/news-contenido.php?cod-news=507 
e culturais enfrentados pelo país. Segundo Lee (2018) no texto Paraguay y las complejidades de una nación bilingüe: la contradicción del idioma guarani como simbolo nacional y su condición de diglosia, não há como pensar em um guarani puro, intocado pelo espanhol. Nas palavras do autor “[...] el guaraní puro está presente predominantemente diccionarios y textos académicos- específicamente, la clase de guaraní utilizados en colegios y universidades” (Lee, 2018, p. 112).

Para Lustig (1996) no artigo Mba'eichapa oiko la guarani? Guarani y Jopara em el Paraguay, é necessário sempre questionar a visão do guarani puro, tal qual apresentado nos manuais, gramáticas e dicionários. Segundo o autor, a noção de pureza linguística do guarani serve apenas para normatizar e apoiar a língua: “[...] cuestionar la imagen de un hipotético guarani puro - que es la forma en la cual la lengua se presenta habitualmente en los manuales de enseñanza, en gramáticas y diccionarios y cuya engañosa visión parece orientar los intentos de normalización y el apoyo oficial a la lengua" (Lustig, 1996, p. 19-20)

Além de se deixar de lado uma visão do guarani como uma língua pura, é preciso desassociar essa língua de seu caráter indígena. Isso porque segundo Lustig (1996, p. 21), mesmo os falantes nativos do guarani já não se identificam com a cultura autóctone, inclusive, um falante do guarani paraguaio pode não entender, por exemplo, quase nenhuma palavra do guarani Mbya e vice-versa. Portanto, para o autor, “[...] cuando utilizamos el término guarani paraguayo, nos referimos a una lengua historicamente derivada del guarani autoctono, sometido a una continua y creciente penetración por el español que sin embargo no ha llegado a destruir su estructura”. (Lustig, 1996, p. 21).

O espanhol não ficou imune nos mais de cinco séculos de colonização e também sofreu inúmeras transformações. Além das transformações sofridas pelo guarani e pelo espanhol, surgiu no Paraguai uma terceira língua, constituída na mescla entre essas duas línguas: o jopará. Na língua guarani jopará significa mistura (Guash, 1996), termo adequado para expressar essa forma de comunicação, que deve ser descrito mais como uma mistura de línguas do que como uma língua misturada (Lustig, 1996, p. 19). 
O jopará pode ser considerado o símbolo da diglossia paraguaia, uma forma de linguagem considerada inferior, mas que ao mesmo tempo representa a maneira como o paraguaio se comunica. O jornal Diário Popular, por exemplo, se caracteriza como um meio de expressão em jopará, como pode ser observado no trecho: "El Ministerio de Salud informó que más de 2.500 personas se contagiaron ra’e. Avei que otras 34 fallecieron por complicaciones con el vairo virus. Hendy la sitú del país en esta pandemia y aún no sabemos cuando tendremos las ansiadas vacunas" . Nesse exemplo, vemos como as palavras em espanhol convivem com o guarani. $\mathrm{Na}$ mesma frase temos as palavras "contagiaron" y "ra'e”, sendo que esta última um sufixo para expressar o passado em guarani, desnecessário no espanhol, mas que marca a utilização do jopará na oração. Nas frases seguintes temos "avei”, significando também; "vairo", uma variante jopará para a palavra guarani vai, feio; "hendy", acender; e "situ", uma abreviação para situación, no espanhol.

No pequeno trecho apresentado, pode-se visualizar palavras em espanhol, guarani e palavras dos dois idiomas que acabaram sendo modificadas no processo de mescla das duas línguas. Base para uma análise que não caberia nos limites deste trabalho, como marco da situação linguística paraguaia atual “[...] El jopara se nos presenta como una zona de interferencia de borrosos límites, difícil de captar y de describir, entre el guarani paraguayo [...] y el español paraguayo, que también ha integrado muchos rasgos - incluso estructurales - del guarani” (Lustig, 1996, p. 19).

\section{Considerações finais}

O fato de o Paraguai ser um dos poucos países da América a ter a língua indígena como língua oficial diz muito sobre a importância do guarani para a realidade linguística do país, mas não diz tudo. É necessário levar em conta os mais de cinco séculos de colonização para iniciar qualquer reflexão sobre a língua - ou as línguas - faladas no país.

Sabe-se que existem muitos estudos a respeito de bilinguismo, diglossia e contatos linguísticos que tem como ponto de partida essa condição ímpar

4 Disponível em https://www.popular.com.py/2021/03/17/covid-19-deja-este-miercoles-un-nuevo-record-de-contagiados-y-una-treintena-de-muertos/. 
do Paraguai. Além disso, existem aqueles apresentam o bilinguismo paraguaio como mito, como estratégia de subalternização da língua indígena.

Diante de toda a complexidade do tema, o objetivo deste trabalho foi apresentar algumas considerações a respeito da situação linguística do Paraguai a fim de que o país vizinho se torne mais próximo e menos desconhecido. Foi apresentado um panorama da história do Paraguai tendo como base a questão linguística, demonstrando-se como a convivência entre o guarani e o espanhol foi marcada por inúmeros fatores sociais, históricos, econômicos e, sobretudo, políticos. Interessante notar que, apesar dos esforços em dirimir a língua guarani, ela se manteve viva e falada como língua dominante de uma parcela considerável da população paraguaia.

Outrossim, foram apresentadas algumas reflexões sobre a situação linguística atual do país, dando breve ênfase ao jopara, manifestação linguística que se constitui na mescla de guarani e espanhol. Tal forma de linguagem certamente renderia uma análise que extrapolaria os limites deste trabalho.

Por fim, espera-se que as reflexões aqui propostas permitam uma aproximação ao universo linguístico paraguaio e se constituam como ponto de partida para futuros trabalhos sobre o tema.

\section{Referências}

CARDOZO, Efraim. Breve Historia del Paraguay. Asunción: ServiLibro, 2009.

GUASH, Antonio \& ORTIZ, Diego. Diccionaraio castellano - Guarani/ Guarani-Castellano. Asunción: CEPAG, 1996.

LEE, Gulherme Von Streber. Paraguay y las complejidades de una nación bilingüe: la contradicción del idioma guaraní como símbolo nacional y su condición de diglosia. Revista Encuentros, Vol.16 No. 01 • Enero - Junio de 2018 • P. 107 - 119.

LUSTIG, Wolf. Mba'eichapa oiko la guarani? Guarani y Jopara em el Paraguay. Revista Papi 4 (2). 19-43(1996) 
MATEO DEL PINO, Maria de los Ángeles. La creación del lenguaje en la mitología guarani. Boletin Millares Carlo, número 12. Artículos de temática filológico-literaria. Las Palmas de la Gran Canaria, 1993 p. 45-51

MELIÁ, Bartomeu. El guaraní conquistado y reducido. Asunción: Biblioteca paraguaya de antropología, 1997.

. El guarani dependiente en tiempos de independencia en Paraguay. Disponível em https://journals.openedition.org/jsa/11904?lang=en Acesso em 18 mar. 2021

MERIDA, José Luis Mora. Historia social del Paraguay, - 1600-1650. Sevilla: Escuela de estudios hispano americanos, 1973.

PARAGUAY. Constitución Nacional. Disponível em https://www.oas.org/juridico/spanish/par_res3.htm. Acesso em 18 mar. 2021

PLÁ, Josefina. Español y Guaraní en la intimidad de la cultura paraguaya. In: Cabiers du monde bispanique et luso-brésilien, n¹4, 1970. pp. 7-21. Disponível em http://www.persee.fr/doc/carav_0008-0152_1970_num_14_1_1750. Acesso em 18 mar. 2021 


\section{CAPÍTULO 2. UM RETORNO ÀS HUMANIDADES PELA LITERATURA: O DIÁLOGO SEM FRONTEIRAS ENTRE A AMÉRICA LATINA E O BRASIL}

Patrícia Helena dos Santos Carneiro

Júlio César Barreto Rocha

\section{Introdução}

Embora trabalhado a quatro mãos, o presente texto brotou originalmente de uma proposta gerada pela primeira autora, que, no interior do evento Charlas Sin Fronteras, imaginou coletivamente, com seus colegas, atividades de mesas redondas com convidados nacionais e forâneos, em uma reunião do Núcleo Docente Estruturante do Curso de Letras-Espanhol, que presidia. Claro que a preocupação central de cada Profissional da docência, em plena pandemia do novo Coronavírus, trazia como um dos objetivos principais impulsionar maior visibilidade para um Curso (dentre tantos) que se tornou secundarizado nos últimos meses, perante a ameaça da morte, que paralisou escolas e universidades no mundo inteiro, deixando a própria ideia do empenho social do Professorado, protagonista do ensino-aprendizagem entusiasmado por desenvolver a Cultura do Povo (e também a empregabilidade), sumida em névoas da incerteza, seja ante o desaparecimento dos contatos pessoais, seja ante um público que se tornava hostil às suas negativas de se atirar à ameaça de morte numa aglomeração de sala de aula ou nos corredores de escolas.

O corpo docente, técnico e discente do Curso de Letras-Espanhol da Universidade Federal de Rondônia possui, dentre os propósitos das suas atividades, a dedicação à finalidade última de uma graduação em licenciatura estrangeira, que é o fornecimento de pessoal para o exercício do magistério na sociedade rondoniense. Nessa condição, essa comunidade profissional sempre vivenciou com bastante sensibilidade o relacionamento do seu aguerrido alunado com frações da sociedade, bem como aliando-se a todos os segmentos acadêmi- 
cos, quando, nos recentes anos, tiveram todos grande destaque nas lutas políticas e sociais, porque buscava-se normativizar, na Assembleia Legislativa do Estado, a obrigatoriedade da oferta de língua espanhola nas escolas públicas ou privadas, uma proposta antiga de décadas, porém nunca implementada de todo, meio que perdida nos últimos anos, recuperada, e depois novamente perdida...

Naquele momento pandêmico, no qual se desenvolve a ideia de replicar em vários momentos de lives públicas o evento Charlas Sin Fronteras, as professoras Mirella Nunes Giracca, Juliana Maioli e Reny Gomes Maldonado se dispuseram a congraçar esforços em favor da construção deste evento como um ponto fulcral de apoio a nos motivar a todos e a todas a somar e a proporcionar ao nosso alunado - mas também à sociedade do nosso Estado- a possibilidade de ampliar a sua formação plural, em um momento da crise da Covid-19, que dificultava a compreensão de qualquer horizonte que salvasse o interesse em temas de formação de professorado que se tornou muito pouco defensável, ante o bloqueio de viagens de estudos, suspensão de contratação de docentes, estancamento de simples lecionamento virtual, ficando cada pessoa sem interesse na erudição, sem sonhos, sem futuro, sem sorrisos, sem cafezinho na lanchonete, sem nada.

Certamente cada docente e cada discente e cada técnico terá um olhar diferenciado para a proposta do evento Charlas Sin Fronteras. Podemos dizer que ele nos terá permitido, através da Universidade, o cumprimento do nosso papel de divulgação da pluralidade de ideias, com a presença virtual, em cada semana, de convidados de luxo, que, de bom grado e sem ônus dinheirário, se desdobravam por resolver-se com o tema que lhes caía a partir da organização do Departamento. Tornou-se a nossa subunidade, também devido a outros eventos, um centro gerador de felicidade, de recuperação dos relacionamentos, um ponto de encontro saneador das almas e também um centro instigador do pensamento científico, a gerar um movimento de crítica cultural, necessária para avançar o desenvolvimento da Sociedade em momento tão difícil, uma tarefa muito bem cumprida pelas Ciências Humanas, colocadas em círculos expandidos e em diálogo interdisciplinar com áreas conexas, como a Filologia, as Humanidades e o Direito Internacional Público, que se tornou capaz de ser, não poucas vezes, o motor da nossa leitura de mundo. 
A partir das nossas próprias inquietações intelectuais, reerguidas no contexto do evento, vividas as suas fases durante o combate ao Covid-19, nessa longa noite de pedra (como diria o poeta galego Celso Emílio Ferreiro) que atingiu a Humanidade, essa sombra que assolou o Brasil e o Mundo, vimos o Charlas Sin Fronteras como uma proposta que pudesse proporcionar ao Alunado do Curso de Letras-Espanhol em particular, e a quem se achegasse (até o máximo que comportasse a nossa sala de aula virtual), uma perspectiva mais pluralizada e mais interdisciplinar, no contexto da Cidadania Globalizada, que com isso nos permitiu fugir dos estereótipos que nublavam as perspectivas de futuro da formação docente, estancada de pronto.

Estas contextualizações se tornam aqui necessárias para que possamos apresentar a nossa Proposta de uma formação possível com eixos humanistas plurais para o Curso de Letras (Espanhol, Português, Inglês, Libras), que bem pode servir de orientação para os cursos da nossa Universidade, tomadas as disciplinas a partir da perspectiva da Cultura, do Direito e da Política Linguística, estatuindo um verdadeiro o diálogo sem fronteiras linguísticas. Este é o nosso propósito textual: agregar mais um tema às maravilhosas Charlas Sin Fronteras, que terá no debate de alguns pontos de Direito, aqui trazidos, a certeza de ter havido uma recuperação das nossas almas, vicejando com mais força o desejo, frente a corpos abatidos por uma enfermidade que um dia minou as nossas esperanças, mas hoje será uma vivência da qual sairemos melhores e mais fortes, reconfigurado-nos para o bom combate que virá.

\section{Um outro olhar sobre as instituições jurídicas e sociais}

A aproximação aos estudos das relações entre o Direito e a Literatura como possibilidade de compreensão da realidade social e jurídica é um diálogo interdisciplinar norteado pelo império da palavra entre esses campos de saberes da realidade ficcional e é marcado pela realidade da normatividade do Direito Positivo.

Nesta relação, talvez desigual, na qual o Direito, refém da sua prisão normativa, mantém como válidas as questões valorativas sobre aquilo que seja 
norma justa ou norma injusta, questões deontológicas conduzem-nos ao centro da questão, do modo como assinala a lição de Bobbio (2008, p. 26):

O problema de saber se uma norma é ou não é justa é um aspecto do contraste entre mundo ideal e mundo real, entre o que deve ser e o que é: norma justa é aquilo que deve ser; norma injusta é aquilo que não deveria ser. Colocar-se o problema da justiça ou não de uma norma equivale a se colocar problema da correspondência entre o que é real e o que é ideal. Por isso costuma-se chamar o problema da justiça de problema deontológico do Direito.

Toda obra literária tem as suas tensões (e distensões) que se podem resolver em termos de normas positivadas. O campo valorativo do Direito sobre o que é a Justiça ou de como alcançar a justiça no âmbito da ficção, constitui um dos grandes temas do Direito. Se colocada a questão em termos mais concretos, uma mesma norma pode ser avaliada de diferente maneira, a depender da causa, do intérprete da lei, do momento político, das circunstâncias regionais ou históricas, dando lugar, por exemplo, a que questões levantadas em outros casos similares tenham distinta resolução quando dispostos na balança os valores de cada componente, em função do renovado contraponto dos fatos com as leis.

A naturalização dos quadros de desigualdades sociais ou dos quadros que ensejam o sentimento de injustiça por boa parte da sociedade tem as suas consequências também na formação dos juristas, vinculados ao estudo de um Direito Positivo distante da possibilidade de uma análise zetética que possa agregar mais humanidade ao texto legal vertido em cada pesado vade mecum ou na descrição da norma jurídica. É preciso relembrar que cada intérprete da norma, por exemplo, das normas de Legislação Educacional, se manifestará pela palavra que deve consubstanciar tanto o Direito positivo como também o aspecto cultural, bem como o consuetudinário, a tradição, a usança. E aí entra o peso da formação filológica, o aprendizado da leitura lenta, tratada alhures por Friedrich Nietzsche, que permitirá enxergar para além do positivismo alcançando possivelmente maior justiça no seu ato interpretativo.

Completamos o nosso pensamento com a contribuição de Lênio Streck (2013, p. 181), ao explicar o chamado giro linguístico, mesclando-o ao campo da interpretação: 
Numa palavra: a viragem ontológico-linguística é o raiar da nova possibilidade de constituição de sentido. Trata-se da superação do elemento apofântico, com a introdução desse elemento prático que são as estruturas prévias que condicionam e precedem o conhecimento. Assim, a novidade é que o sentido não estará mais na consciência (de si do pensamento pensante), mas, sim, na linguagem, como algo que produzimos e que é condição de nossa possibilidade de estarmos no mundo. Não nos relacionamos diretamente com os objetos, mas com a linguagem, que é a condição de possibilidade desse relacionamento; é pela linguagem que os objetos vêm a mão.

Neste contexto debulhado por Streck, a Literatura, pelo seu universo ficcional, verte luz sobre as realidades sociais das quais fala, cada um objeto do Direito, com as suas marcas derivadas de outras áreas de conhecimento, e assim permite-se haver uma análise para além do simples olhar positivista da norma.

O uso da palavra é o ponto de união entre o Direito e a Literatura, como ferramenta, sendo o Direito o portador do rigor e da rigidez, a evoluir em cada época, e a Literatura catalisadora da sugestão e da abertura da obra, a fixar-se a sua interpretação através do tempo, não raro desviando-se muito daquilo que era a proposta de insinuação e de variação hermenêutica. Aqui os espaços à Filosofia trazem propostas amplas e variadíssimas e muita tinta já se imprimiu sobre áreas que vão da Estética à Lógica formal.

A discussão neste campo é claro que ultrapassa questão puramente estética ou artística, porque o nosso interesse percebe a importância de resgatar os contextos da presença do Direito de pessoas ou da ausência do Direito de coletividades em obras de ficção que abrem janela para o debate sobre a Cidadania, dentro de salas de aula de escolas, de universidades e de lares educadores.

A consciência de cidadania, assegurada no Direito a ter direitos (Arendt), só nasce mediante o conhecimento da existência de um plano normativo de direitos e de garantias como as previstas na Constituição Federal, muitas vezes atropelada sumariamente nos interiores deste Brasil varonil, menos por maldade do que por ignorância. O melhor lugar para abrir as janelas da mente é aquele destinado à formação de docentes e, por essa categoria, dedicado à formação das pessoas em idade escolar. 
Pode-se desenvolver o senso estético com a alusão a leituras que reflitam a condição social sem a preocupação com uma concretização direcionada à tomada de conhecimento para a ação transformadora do social e da própria existência vital da pessoa em formação.

Assim, a leitura aplicada em sede de Direito e Literatura, ao contrário, aprecia também ao senso estético, mas dirige o seu olhar para as possibilidades transformadoras que a Literatura pode impulsionar em crítica ao que não funciona na realidade fáctica, surpreendida a mesma através dos anos ou mesmo dos séculos.

Para Arnaldo Godoy, em termos teóricos, há sete ramos de estudos abarcados pelo Direito e Literatura: 1) o Direito na Literatura; 2) o Direito como Literatura; 3) Literatura como proposta de instrumento de mudança do Direito; 4) Direito e Ficção; 5) Hermenêutica; 6) Direito da Literatura; e, finalmente, 7) Direito e Narrativa (Godoy, 2008, p. 17). O nosso interesse é justamente o Direito na Literatura porque é o Método dobrando-se sobre o seu Objeto assim como o telescópio observa o movimento dos astros cósmicos.

O imenso rol de assuntos que podem estudados a partir da aplicação desta possibilidade de estudo do Direito na Literatura engloba temas como o direito à educação, os direitos linguísticos, o direito à cultura, o direito das minorias, o direito das mulheres, o direito dos refugiados, o direito dos povos indígenas, o direito ao meio ambiente, dentre muitíssimos outros direitos.

Esse formato de orientação humanística em obras que possam conscientizar o professorado na Educação brasileira encontra amparo no artigo de abertura da Constituição Federal de 1988, quando elegeu a Dignidade da Pessoa Humana como princípio-fundamento da República Federativa do Brasil. Emitindo os seus efeitos à parte, chamaremos de Constituição Educacional o recorte da Carta Magna formado pelos artigos 205 ao 214, que enlaça toda a Educação Brasileira, seja pública ou privada, como direito pleno, não como simples expectativa de direito. Neste mesmo sentido, a Lei no 9.394, de 20 de dezembro de 1996, que estabelece as diretrizes e bases da educação nacional, segue nos seus artigos $2^{\circ}$ e $3^{\circ}$ os mesmos parâmetros humanistas da Constituição Federal, devendo ser levadas às últimas consequências as atribuições 
forçosas ao ente público ou privado, sob pena de persecutio judicial, seguindo denúncia do Ministério Público.

Relembramos aqui o Plano Nacional de Educação, a Lei no 13.005, de 25 de junho de 2014, com vigência (a cada vez) por dez anos, o qual estabeleceu no seu artigo $2 .^{\circ}$, dentre outras diretrizes, o imperativo da superação das desigualdades educacionais, com ênfase na promoção da Cidadania e na erradicação de todas as formas de discriminação (III); bem como a promoção humanística, científica, cultural e tecnológica do País (VII), com a promoção ainda dos princípios do respeito aos Direitos Humanos, à diversidade e à sustentabilidade socioambiental $(\mathrm{X})$.

Devemos destacar ainda a Lei de Diretrizes e Bases da Educação Nacional, a qual, nos seus artigos 61 a 67, articula os aspectos direcionados aos profissionais da educação e à formação docente, tendo passado por alterações recentes, como normas da Lei no 13.415 , de 16 de fevereiro de 2017, assim como a Lei no 13.478 , de 30 de agosto de 2017. Neste contexto, a Resolução $\mathrm{CNE} / \mathrm{CP}$ n$^{\circ}$ 2, de 20 de dezembro de 2019, "define as Diretrizes Curriculares Nacionais para a Formação Inicial de Professores para a Educação Básica e institui a Base Nacional Comum para a Formação Inicial de Professores da Educação Básica (BNC-Formação)", e com isso determina uma formação docente composta por uma perspectiva intercultural, em termos principiológicos, tal como se comprova, verbis:

Art. 70- A organização curricular dos cursos destinados à Formação Inicial de Professores para a Educação Básica, em consonância com as aprendizagens prescritas na BNCC da Educação Básica, tem como princípios norteadores:

$[\ldots]$

XIV- adoção de uma perspectiva intercultural de valorização da história, da cultura e das artes nacionais, bem como das contribuições das etnias que constituem a nacionalidade brasileira.

Neste contexto, a formação docente nas Licenciaturas pelas Universidades deve atender às exigências constitucionais de uma educação mais plural 
e humanista. Neste diapasão, a Literatura em diálogo com o Direito, objeto exibindo-se ao seu método, propicia espaço para a construção crítica do pensamento educacional vinculando a ficção ao mundo dos direitos em perfeito formato de complementaridade.

Há inúmeras obras da Literatura que podem ser lidas sob o prisma do Direito. Quase todas, na verdade, embora algumas sejam preferenciais, pela tradição, como ocorre com Antígona, personagem-título que colide frontalmente com Creonte, símbolo hoje do Estado-nação moderno que não pode vacilar ante a circunstância da repressão ao descumprimento de normas. Alguns textos, porém, mais do que pela tradição, na contemporaneidade, nascem como que literários, emanando ideais de Ética, a permitirem-se dialogar melhor com o Direito ou com outras áreas para formatar consciências, como defende Eagleton (2006, p. 10):

Aqueles que proclamam a necessidade de um período de incubação ética para preparar homens e mulheres para a cidadania política incluem os que negam aos povos coloniais o direito à autodeterminação até serem suficientemente «civilizados» para o exercício das suas responsabilidades.

Nem tanto esperar período ou fase de preparação para o exercício da consciência da Cidadania política, no ambiente escolar ou no direito das gentes, nem tanto correr com estudos de Direito que possam permitir uma axiologia frouxa, diante de muita construção retrógrada e mesmo ditatorial que tantas obras apresentam, negando-se a saber que a fila anda, e que novos direitos serão sempre mais demandados, ainda que algum regime de força queira se impor de modo renegado, frente ao Planeta que envelheceu, mas não ficou caduco ou com vontade de ser ultrapassado pela Civilização que avança.

\section{A Literatura como campo de Resistência na América Latina}

De todos os autores com que trabalhamos, Milton Hatoum e Márcio Souza são exemplos de criação de Literatura maiúscula que, do nosso lado amazônico, podem ser recolhidos para estudos com formato da resenha típico de arte engajada, 
sempre em mãos um referencial grande aos direitos humanos, entendidos aqui também os Direitos Indígenas, como entidade sempiterna e onipresente.

Observamos em algumas obras suas, por exemplo, o permanente estado de resistência de personagens indígenas, que aparecem subalternizados, silenciados pela hierarquização social, presente nas relações tidas numa Amazônia Indígena, mas comandadas pelos interesses do poder político de cada momento histórico.

A presença da América Latina, da democracia golpeada e dos direitos indígenas tripudiados são algumas trilhas da memória na obra recente de Milton Hatoum, Pontos de Fuga, o segundo livro da trilogia O lugar mais sombrio, resgatando algo da História de rupturas políticas e sociais que já se fizera presente nas suas Cinzas do Norte.

No mosaico latino-americano da diversidade cultural, típico na obra, é possível refletir sobre a questão linguística ou sobre o Direito Linguístico dos Povos Indígenas, em uma América Latina marcada pela dominação linguística ou da Língua Portuguesa ou da Língua Castelhana, a enxovalhar os idiomas autóctones como se fosse melhor para os seus utentes. Já se sabe que a reivindicação identitária vem atrelada ao direito a falar a sua própria língua, já recolhido na Constituição Cidadã de 1988.

Os protagonistas de Hatoum mostram existir descompasso internos, na mesma (gigantesca) região, com o desconhecimento dos brasileiros sobre si mesmos, sobre as suas origens indígenas, ao mesmo tempo em que revela a consideração que se atribui ao indígena, seja no Brasil ou no Chile:

Antes desse sonho, o caminhão parou num lugar sinistro: duas lâmpadas acesas de uma gasolinera, uma casinha sem cor e um frentista que dava passos de sonâmbulo; uma sombra surgiu na estrada, acenou pro motorista e subiu na carroceria. Era um poeta peruano. Acendeu uma lanterna, olhou para nossos rostos e nos ofereceu um folheto com poemas quéchuas que traduzira pro espanhol. Disse que eu era indígena. Falei que a maioria dos brasileiros tem sangue indígena, muitos nem sabem disso. 'Mas tu sabes', afirmou o peruano. 'Teu rosto, tua alma, teus antepassados.' Então começou a falar das civilizações pré-colombianas enterradas no Atacama, das crianças incas sacrificadas e enterradas no topo das montanhas. Quando 
recitou poemas no fim da noite, olhando as cores fortes no céu, me lembrei das vozes da infância, elas atravessavam o tempo e as cordilheiras e ressurgiam no deserto do Chile, misturadas com a voz de um peruano bilíngue. Esse nômade no Atacama dorme em galpões abandonados, ou na terra do deserto, de cara para a lua; lê poemas e canta para os mochileiros que vêm de Santiago ou Lima. O folheto era gratuito, mas ele aceitava uma propina. Celeste deu um dólar pro poeta, eu e ela dormimos um pouco, acordei com frio e com as imagens do sonho. Na parada obrigatória em Arica (Regimento Rancagua, Quinta Companhia), o motorista saiu da cabine e eu perguntei pelo peruano. 'Já se foi', respondeu. 'Esses índios nem agradecem a carona. Querem a desgraça do Chile, querem reconquistar o Norte.' (Hatoum, 2019, p. 120.)

A memória das vozes da infância denota a força de uma resistência que, também por ser, então, iletrada (ou simplesmente analfabeta), também aparece firme quando um dos seus personagens relembra a herança comum dos países latino-americanos, cujos golpes militares, vez ou outra, apoiados pela ação imperialista norte-americana, mesclados à imagem artística ou musical, vem à tona na constatação de debate sobre o uso das línguas e das suas circunstâncias:

As aulas de canto em Berkeley afinaram minha voz. Cantei num recital de poesia em San Francisco para uma plateia com muitos exilados latino-americanos, africanos, asiáticos e expatriados mexicanos. Ken, um poeta norte-americano, leu em inglês e espanhol um poema à memória de Victor Jara. O poeta estava em Santiago durante o golpe de 73, foi preso pela polícia chilena e interrogado por um compatriota, agente da CIA. Ken falou do terror de Pinochet e das atividades sinistras da CIA no Chile e em países da A. do Sul e Central. Não quis ouvir tudo, a violência me faz mal, Martim. Depois assisti a uma peça ao ar livre e me lembrei de uma noite num teatro do Bexiga, tu e outro ator no palco dividido por uma tela de tecido transparente, os dois fazendo perguntas sobre a relação com os pais, indagações para si mesmos, sem respostas. Eu estava lá com dois amigos músicos, a Eliete e o Arrigo. Você escapuliu depois da encenação, conversei com os meus amigos sobre a peça, dormi pensando nas palavras, na impossibilidade de ser compreendido, na perda de humanidade. $\mathrm{O}$ outro ator falou dessa 
perda, um trauma sem fim, até recordei uma frase de um artigo sobre uma peça que vi quando era muito jovem: 'Seria desumano humanizar o desumano'. (Hatoum, 2019, p. 168-169.)

Outro "Ponto de Fuga", nessa mirada conjunta da América Latina, coloca a personagem Laísa, amiga do mesmo Martim de Cinzas do Norte, em Vilhena, Rondônia, na Aldeia Alantesu, território indígena nambiquara, com data certa: em 9 de novembro de 1979 (Hatoum, 2018, p. 217). Em uma quase apresentação antropológica deste Brasil plural e autodestrutivo, Laísa conta em carta ao amigo Martim o cotidiano daquela comunidade indígena:

Saio pouco daqui, Martim. De vez em quando vou a outra aldeia nambiquara, raramente dou um pulo até Vilhena e Porto Velho. Eu e Marcela dormimos numa das sete casas pequenas e redondas. Uma cabana sem porta, com um jirau onde a gente deixa nossas coisas. A primeira atividade do dia é buscar água fresca no igarapé, nessas manhãs com neblina vejo alguns indígenas deitados no chão, eles conversam até tarde e dormem perto da fogueira, o corpo coberto por uma fina camada de cinzas; depois vão com suas famílias até o igarapé, tomam vários banhos por dia, todos brincam e mergulham. (Hatoum, 2018, p. 218.)

Essa diversidade cultural com um embate normativo pela invasão sempiterna é apresentada de forma naturalizada, demonstrando-se outras possibilidades a formatos familiares, sem que escasseie a possibilidade de interpretação jurídico-cultural:

De tarde as mulheres brincam com as crianças, trançam cestos, ralam milho pra fazer chicha, enterram mandioca na beira do igarapé e depois preparam puba; os homens consertam instrumentos de caça e pesca, descansam, visitam os vizinhos. Os poucos objetos (cestos de vários tamanhos, arcos e flechas, brincos e colares) são trocados por panelas e roupa. É comum dois homens viverem com uma mulher, e duas mulheres com um homem, relações ligadas à sobrevivência. Quando um indígena diz: 'Aquele fulano está muito sozinho e eu estou muito cansado', eles passam a morar com a mesma mulher e dividem as atividades cotidianas. (Hatoum, 2018, p. 218.) 
Mais comum do que possa parecer a olhos forasteiros na região, não é difícil percebermos presenças de casais diferenciados, verdadeiras "constelações familiares" à nossa volta, cada qual com a sua sensibilidade distinta daquele formato que nos parece querer impor a regularização do Estado-nação moderno, que dificilmente conseguirá digerir as suas singularidades com simples persecucionismo do tipo satanização ideológica. Ao seu lado, volta e meia ressurge a língua como elemento agregador do autóctone e ao mesmo tempo de exclusão do outro, tudo num cadinho bem homogêneo quanto ao distanciamento da regularidade exótica, como se observa fácil em muitos trechos, dos quais destacamos estes:

No fim do inverno passado, o chefe da aldeia disse que um jovem, o Ôyo, queria casar comigo, ele ia fazer muito xixiri na nossa rede. Falou em nambiquara, Marcela boiou, uma língua desconhecida deixa a pessoa ausente, com ar indagador. A enfermeira do posto me tirou da enrascada e nos mandou pra uma aldeia wasusu, onde havia uma epidemia de malária. (Hatoum, 2018, pp. 218-219.)

Meu convívio com os indígenas faz mais sentido se eu falar a língua deles, com a ajuda da enfermeira meu dicionário nambiquara-português cresce dia a dia. $\mathrm{O}$ estranhamento nos convida à compreensão, tentei afastar o medo ao que é diferente, o medo e a rejeição surgem quando a gente menos espera. (Hatoum, 2018, p. 219.)

A malária, o sarampo e a gripe ameaçam e matam os nambiquaras. Fazendeiros e madeireiros cercam e invadem terras indígenas, eles jogam desfolhante químico na floresta, várias crianças de uma aldeia do Sararé nasceram com lábio leporino, há casos de cegueira e distúrbios neurológicos, a enfermeira do posto foi para lá, ela trabalha há sete anos nas aldeias da mata e do cerrado. (Hatoum, 2018, p. 221.)

Claro que é o diferencial da sensibilidade, do convívio, sob as enfermidades, empioradas pelos desfolhantes, que se apresenta como complicador-destruidor, sem que reste muito espaço para dizer da falta que faz um órgão setorial de controle, nas proximidades das regiões de vivências indígenas, em 
que a Lei obriga a proteção estatal. Cuide-se aqui de destacar o imperativo de situar estes acontecimentos no ano de 1979.

Também é claro que a compreensão do outro sobre ao palco, quando a personagem é especialista na área: facilita o trabalho do romancista que precisa de olhar da pessoa que compreenda a situação de diferenciação e tenha o condão de estabelecer a diferença facilitadora desse entendimento de outrem:

No meu diário de etnóloga e auxiliar de enfermagem anoto a situação dos doentes e a dosagem dos medicamentos; observo o dia a dia na aldeia: quem casa com quem (é comum um homem casar com sua enteada), como os índios se relacionam entre si e com os visitantes. De noite, no pátio de terra, ouço o mais velho da aldeia falar sobre as cavernas sagradas, um dos lugares da cosmologia dos povos indígenas do Guaporé. Um deus está presente em tudo; outro deus, espírito sábio e poderoso, diz o que é certo e errado, as regras que devem ser respeitadas para dar harmonia ao grupo. (Hatoum, 2018, p. 222-223).

Ouço a voz do ancião e tento traduzir mitos, histórias de deuses e espíritos, nomes de aves mágicas que trazem o bem e o mal, versões sobre o mundo natural e o sobrenatural. Mundos inseparáveis: a Natureza, as pessoas, os espíritos. As histórias dos alantesus, wasusus e outros nambiquaras diferem umas das outras, dependem da voz, da memória e da imaginação de cada um. Dependem também da minha tradução. Meu diário é apenas uma aprendizagem, Martim. E apesar dos meus erros e vícios, é uma tentativa de traduzir uma cultura, outra forma de existência. Escrevo para aprender o que sou, diante dos outros e na visão deles. E se aprendi alguma coisa, é que esses outros, com suas visões, podem fazer parte de mim e enriquecer minha vida. Ox me viu numa foto recente com os nambiquaras e disse que "a filha do padeiro luso-brasileiro agora é indígena e branca, mestiça de muitos olhos". (Hatoum, 2018, p. 223.)

Não obstante essas críticas agudas, em que a norma se esfacela diante do entrechoque das culturas distantes dos grandes centros, o romancista parece se deixar seduzir pela utopia Mariosvaldiana de Andrade, querendo nos fazer crer que o Brasil pode se reconhecer como indígena: "Ox me viu numa foto recente 
com os nambiquaras e disse que 'a filha do padeiro luso-brasileiro agora é indígena e branca, mestiça de muitos olhos"'. (Hatoum, 2018, p. 223)

Não é desconhecida de ninguém a impossibilidade de a pessoa, na sua usança de autóctone, jamais lograr abandonar a sua casca de indígena (ainda que muitos tentem, por gerações), bem como se sabe que o mais comum é o inverso: a coletividade indígena pode adotar e reconhecer o não-indígena, como, por exemplo, pela adoção consentida e desabrida em idade varonil, seduzido pelos belos olhos de aldeias inteiras a refletir a sua vontade de retornar às origens. E essa inversão não estará somente em Rousseau, mas provavelmente se encontra nos próprios genes, indóceis ao Direito positivo.

E com isso cada passo de uma grande obra literária amazônica, e de Hatoum todas vêm sendo magistrais, haverá uma noção jurídica ou mais, uma definição normativa, um pé de briga para a conceituação de uma descrição no bom Direito Consuetudinário, um entrechoque valorativo com leis da Capital que ainda não desistiram de domesticar os sertões e de agrilhoar, com o nó da Cidadania Constitucional, aquilo que jamais deixará de ser hinterland e de ser distante, cuja reação virá nos doar materiais novos de referenciação cultural concreta, reservas de recursos para a comparação, fatos sociais ficcionados que farão saltar chispas de olhos informados pela nossa teoria de Direito na Literatura, como privilegiado campo de Resistência na América Latina.

\section{Um Retorno às Humanidades}

A primeira pergunta que se pode fazer, nas circunstâncias até aqui descritas, cuida de saber qual seria, afinal, a finalidade da formação docente nas licenciaturas. Para atentar às possibilidades de resposta, trazemos à baila Walter Benjamin, para quem, em seu conhecido texto "A Obra de Arte na Era da sua Reprodutibilidade Técnica". Aqui, ele discute a possibilidade da utilização da arte mais vinculada ao que conhecemos como arte engajada, sem descuidar aquele autor, da possibilidade de utilização da arte também para a deseducação das massas quando mobilizadas para a destruição do Outro. Neste contexto, parece-nos atual a reflexão deste Benjamin quando escreve: 
A crescente proletarização do homem contemporâneo e a crescente formação de massas são duas faces da mesma medalha. $\mathrm{O}$ fascismo tenta organizar as massas recentemente proletarizadas, sem tocar nas relações de propriedade que estas pretendem eliminar. $O$ fascismo vê a sua salvação no facto de permitir às massas que se exprimam, mas, de modo nenhum, que exerçam os seus direitos. (Benjamin, 2018, p. 70.)

A política de propaganda do multiculturalismo desenvolvido na América Latina é apresentada como uma proposta culturalista para os povos indígenas e na verdade esta proposta não estaria verdadeiramente para contribuir um espaço de conquista de direitos para os povos indígenas ou grupos diferenciados dentro dos Estados nacionais. Há uma pluralidade discursiva que tenta associar a interculturalidade ao multiculturalismo (Zapata Silva, 2017, p. 3772). Ao proceder assim, não obstante exalte a cultura dos povos indígenas, deixa-se de enfatizar a construção do Sujeito de Direito que se realiza através do processo histórico travado nas dinâmicas tensionadas no contexto dos Estados. Procurando entender esse passo, seguimos apoiados em Díaz-Polanco, de quem buscamos a síntese do que verdadeiramente proporia o Multiculturalismo:

El multiculturalismo se ocupa de la diversidad en tanto diferencia 'cultural', mientras repudia o deja de lado las diferencias económicas y sociopolíticas que, de aparecer, tendrían como efecto marcar la disparidad respecto al liberalismo que está en su base. Pues el multiculturalismo querría ser una propuesta de validez universal, le espanta que su sentido liberal se ponga de manifiesto como una solución particular. Lo que quiere evitar no es tanto que se revele su contenido 'eurocéntrico' o de alguna otra matriz cultural, sino que quede al descubierto que la decisiva particularidad de su 'universalidad' es la globalización del capital. (Díaz-Polanco. 2015, p. 43.)

Zapata Silva, na obra Intelectuales indigenas en Ecuador, Bolivia y Chile: Diferencia, colonialismo y anticolonialismo, apresenta análise sobre a relação entre a educação de corte assimilacionista ofertada pelos ditos estados nacionais aos indígenas e a tentativa de não reconhecer o indígena enquanto sujeito com uma cultura diferenciada: 
El predominio de estas reflexiones implicó que el indio fuera incorporado al discurso moderno, teniendo la posibilidad concreta de ser ciudadano, pero en la medida que abandonara su condición de indio, un tránsito que debía estar mediado por el sujeto nacional que era el mestizo. Esto explica la centralidad que adquiere la pedagogía, tema recurrente en todo el continente y por cierto en los países que aquí nos ocupan, pues se entendió que la educación era el mecanismo privilegiado de integración y redención de los indígenas. Por lo tanto, se trató de una integración condicionada, en favor de comunidades nacionales homogéneas donde los indígenas no tenían cabida como sujetos culturalmente diferenciados. De ahí la clave del mestizaje como metáfora del orden, la armonía y la confluencia. (Zapata Silva, 2017.)

Pela nossa perspectiva, a Literatura de Resistência de Milton Hatoum, em análise neste Capítulo, apresenta outra possibilidade de mirar a questão da diversidade cultural no Brasil, colocando o sujeito indígena não mais como objeto, mas como sujeitos de direito sem deixar de lado a sua tradição, cultura e língua, tal como se verifica na obra Pontos de Fugas, de Hatoum. No Brasil, temos já uma produção literária de Resistência indígena construída por nomes como Daniel Munduruku, Aílton Krenak, Márcia Cambeba, Eliane Potiguara, dentre outros nomes que assumem a transformação do real pela palavra. Neste sentido, a partir da Literatura como campo de Resistência, no Chile, os escritores, poetas, indígenas mapuches apresentam a categoria de champurria, palavra da língua mapuche que significa mescla (linguística, cultural), e se trabalha com ela como categoria política, tal como informou Zapata Silva em sua conferência de 18 de agosto de 2020, no evento Charlas sin Fronteras, na Universidade Federal de Rondônia. Distingue-se da mescla ou mestiçagem defendida pelos governos para castrar o Retorno às Humanidades que a sociedade precisa admitir, facultando o seu reconhecimento pelas escolas, pelos bancos das universidades; admitir que somos muito mais plurais do que ousaria discutir a nossa vã filosofia se estiver despida de estudos do Direito na Literatura.

Os cursos de Licenciatura, em particular os cursos de Letras, de Filosofia, de Pedagogia e de História, podem contribuir a esse Retorno às Humanidades aplicando aos currículos formativos um maior destaque à presença de tópicos 
voltados ao estudo das Literaturas de Resistência, com isso dando maior consistência intelectual ao conjunto disciplinar, capaz então de agregar o domínio dos enredos literários, mas também favorecendo a criticidade necessária para o desempenho do professorado, como seres políticos e formadores de consciências.

\section{Considerações Finais}

O Brasil precisa se reencontrar a si mesmo, ente perdido no caminho da autoafirmação, assim como a América Latina também precisa olhar mais para si mesma e especialmente sobre as suas relações da sociedade envolvente com os povos indígenas. É preciso reencontrar o caminho da Humanidade da América Latina e do Brasil e esse caminho cremos que passa necessariamente pelo processo de educação na formação docente: é preciso formar o docente para a convivência intercultural e no conhecimento da diversidade linguística e cultural, seja dos povos indígenas, seja de comunidades transplantadas que preservam o seu instrumento idiomático e a sua convivência culturalizada. Tal formação docente deve inevitavelmente incidir na compreensão do Princípio da Dignidade da Pessoa Humana como elemento orientador para a sua prática

educadora. É preciso formar o docente para a compreensão da cultura do $\mathrm{Ou}$ tro, ou seja, para a compreensão do Direito à Diferença.

A Literatura de Resistência de Milton Hatoum é possibilidade de leitura para a retomada dos valores positivos para o retorno a uma sociedade mais humanizadora que respeite a diversidade cultural.

Neste processo de retomada aos valores supremos do direito à vida, do direito à diferença, a formação docente passa a ser tarefa crucial, que exigirá maior compromisso das universidades e, principalmente, das licenciaturas.

A Literatura de Resistência pode contribuir com os cimentos humanistas na formação docente para construir armadura crítica suficiente para enxergar além da base teórica e conteudista e somar no processo de reconstrução de um país que, como diria Chico Buarque, perdeu o equilíbrio de si, isto é, no nosso caso brasílico e latinoamericano, teria perdido a sua delicadeza ancestral $^{1}$. Conduzida uma formação docente nestas bases libertadoras dos preconceitos, mais próximo estará o Brasil para ser um país livre, justo e solidário.

1 Ver Chico Ou O País Da Delicadeza Perdida. Show musical. Sony Bmg Europe, 1989. 
Com isso, essa educação transformadora dependerá também do compromisso político do Estado brasileiro, seja no cumprimento de normas internacionais internalizadas (Convenção n. 169, da Organização Internacional do Trabalho) seja da própria Constituição Federal, normas destinadas a garantir direitos aos Povos Indígenas. As universidades decerto participam deste compromisso, como disseminadoras de informações em favor de Direitos Humanos, ofertando uma formação docente interdisciplinar e humanizadora que possibilite ao licenciando alcançar criticidade suficiente ademais do aspecto de formação no núcleo duro da sua graduação específica.

A retomada do sonho de composição da comunidade latino-americana exige essa prática educadora, fundada em valores fraternos e solidários, e amparada constantemente pela Ciência e Estudos desenvolvidos pelos pesquisadores, sem perder de vista a necessidade de repisar sempre os caminhos da História comum de lutas dos povos latino-americanos. É preciso destituir o multiculturalismo que subalterniza os povos indígenas e priorizar a interculturalidade como prática política que respeita o Outro e admite a pluralidade cultural e linguística. Este é o caminho de retomada da Humanidade para a América Latina bem como para o Brasil.

\section{Referências}

BENJAMIN, Walter. A obra de arte na era de sua reprodutibilidade técnica. L\&PM Editores. 2013. Edição do Kindle.

BOCCARA, Guillaume. Poder colonial e etnicidade no Chile: territorialização e reestruturação entre os Mapuche da época colonial. Revista Tempo, Niterói, v. 12, n. 23, p. 56-72, 2007. Disponível em: <http://www.scielo.br/scielo.php?scrip$\mathrm{t}=$ sci_arttext\&pid=S141377042007000200005\&lng=en\&nrm=iso >. Acesso em: 01/12/2020. https://doi.org/10.1590/S1413-77042007000200005.

BONNICI, T. O pós-colonialismo e a literatura: estratégias de leitura (1990-2001). 2nd ed. Maringá: Eduem, 2012. Edição do Kindle.

DÍAZ-POLANCO, Héctor. El jardín de las identidades: la comunidad y el poder (Antropología y etnología) (Spanish Edition) ORFILA. Edição do Kindle. 
EAGLETON, Terry. A Ideia de Cultura. São Paulo: UNESP, 2011.

GODOY, Arnaldo Sampaio de Moraes. Direito e Literatura. Ensaio de Síntese Teórica. Porto Alegre,Livraria do Advogado, 2008.

HATOUM, Milton. Pontos de Fuga. O Lugar Mais Sombrio 2. Edição do Kindle. São Paulo: Companhia das Letras.

STOCCO, Melisa. El concepto de taypi ch'ixi como aporte al estudio de la poesía mapuche bilingüe. Mundo Amazónico, Vol. 9, n. 1, 2018, p. 87-103. http://dx.doi.org/10.15446/ma.v9n1.64628

\section{STRECK, LENIO LUIZ. O Que é Isto Decido Conforme Minha} Consciência? Livraria do Advogado Editora. Edição do Kindle.

ZAPATA SILVA, Claudia. "Origen y función de los intelectuales indígenas". In: Cuadernos Interculturales, Año 3, no 4 . Centro de Estudios Interculturales y del Patrimonio. Valparaíso: Universidad de Valparaíso, 2005, p. 65-87.

. Intelectuales indígenas en Ecuador, Bolivia y Chi-

le: Diferencia, colonialismo y anticolonialismo (Spanish Edition). Santiago de Chile, LOM ediciones. 2017. Edição do Kindle. 


\section{CAPÍTULO 3. CONTEXTO DA LIVE DIFICULTADES YPRO- PUESTAS METODOLÓGICAS: REFLEXIONES ACERCA DE LA ENSEÑANZA DE ELE PARA BRASILEÑOS}

Elton Emanuel Brito Cavalcante

\section{INTRODUÇÃO: O PORQUÊ DA LIVE}

A charla que servirá de mote para este artigo titulou-se Dificultades y propuestas metodológicas: reflexiones acerca de la ensenanza de ELE para brasilenos ${ }^{1}$, tendo como convidadas as professoras Silvina Morales² y Mariela Gutiérrez ${ }^{3}$. Como o próprio título o indica, a temática discorreria sobre as dificuldades dos brasileiros que, ao estudar espanhol com afinco, percebem o quão complexa é tal língua. Por serem o espanhol e o português dois idiomas mui similares no léxico e nas estruturas sintáticas, causa isso a falsa percepção de que a língua de Cervantes é fácil para um luso-falante. Seria ingênuo, todavia, afirmar que para um brasileiro, por exemplo, aprender espanhol é mais difícil do que aprender inglês ou alemão. Sem embargo, o grau de distanciamento, em termos fonológicos, é alto entre ambas línguas romances. O portunhol serve como forma de comunicação eficiente até um certo ponto, ou seja, é útil em situações que não exigem de ambos falantes estruturas linguísticas mais complexas. Quando um luso-falante viaja a um país hispano e insere-se na cultura e costumes locais, quando tem quefazeres rotineiros, tais como resolver pendências burocráticas, consultar-se com um médico, buscar emprego etc., ou seja, situações em que as pessoas não têm o tempo ou a paciência para falar lento, pronunciando todas as sílabas, evitando contrações, inversões sintáticas, modismos, gírias, então, tal luso-falante notará o quanto o espanhol é, de verdade, bem diferente do por-

1 Tal live ocorreu no dia 16.06.2021, e está disponível em https://www.youtube.com/channel/ UC4xnnJUdzbwzZNCX3S1VXhA

2 Professora especializada nos estudos da variabilidade pragmática entre espanhol e português. É diretora de SET Idiomas Centro Acreditado Instituto Cervantes - Córdoba -Argentina.

3 Mariela Magali Román Gutiérrez é professora de espanhol, inglês e francês em Cusco, Peru. Ademais, é bióloga, com especialidade em botânica e ecologia. 
tuguês. Afirmar que é "fácil" é não reconhecer, nem de longe, as idiossincrasias do espanhol, suas variedades e nuances.

Pelo supradito, o autor deste texto não se contentava apenas em compreender o espanhol falado por pessoas cultas ou em filmes e documentários, necessitava ingressar no "espanhol profundo", isto é, aquele falado por lavradores, peões, campesinos, mendigos etc.; desejava dominar todas as variações do espanhol "callejero". Para tanto, predispôs-se a viajar a muitos países hispano-falantes, não visitando, porém, apenas as cidades turísticas, mais bem adentrando em regiões onde a língua espanhola se mescla com outros idiomas, é pronunciada de distintas formas, e aí buscou o autor adaptar o máximo possível sua audição a tais variações. Ele, aficionado que é pela gramática normativa espanhola, advoga pela importância desta, mas, desde sempre, soube das limitações dos estudos gramaticais para o domínio competente de um idioma. Para atingir domínio pleno nas quatro competências linguísticas ${ }^{4}$, necessário se faz mergulhar tanto culturalmente quanto linguisticamente no idioma-alvo. E foi isso o que o autor tentou. Entretanto jamais deixou de fazer em suas andanças cursos de capacitação em instituições credenciadas. Nestas, deparava-se com uma realidade insólita: professores tendo em suas salas alunos de diversas nacionalidades, idades e interesses. Em Córdoba, Argentina, presenciou, em certo instituto, algo distinto: dezenas de alunos brasileiros, em sua maioria adolescentes, alguns acompanhados pelos pais, indo fazer intercâmbio linguístico. Por suas idades, o que mais queriam era conhecer os pontos turísticos e ter um pouco de aventura: tudo para eles era festa e barulho. A pergunta que o autor se fazia era: estão de fato aprendendo espanhol ou apenas "curtindo" algumas semanas em um lugar bonito? Sim, estavam aprendendo, pois, como diz a professora Mariela ${ }^{5}$ Gutiérrez, os brasileiros aprendem espanhol como se este fosse sua língua nativa.

De fato, tais jovens não buscavam a pronúncia perfeita ou um acento igual ao de um argentino. É dizer, simplesmente falavam e iam aprendendo naturalmente com os seus erros e as orientações dos seus professores,

4 Escutar, falar, ler e escrever são quatro habilidades linguísticas básicas.

5 Essa fala da dita professora será melhor comentada em um capítulo deste artigo. 
possuíam uma desenvoltura que os ingleses e alemães, também estudantes, não possuíam, e isso pelo fato da proximidade morfossintática entre o português e o espanhol. Mesmo assim, quando falavam espanhol, ademais dos erros gramaticais, possuíam um forte acento brasileiro. Eles não se importavam com isso, pois os próprios professores lhes diziam que isso não era, ao menos naquele momento, o fundamental.

Ocorre que o ensino do espanhol não se limita a tais grupos, pois há estudantes de nível elevado que buscam reduzir seu acento, contratando fonoaudiólogos ou fazendo cursos intensivos em instituições de nível avançado, como é o caso do Instituto Cervantes na Espanha. Por isso, o autor conversava com suas professoras sobre tal situação: como lidar com alunos de espanhol que têm distintos objetivos, níveis e disciplinas de estudos? Essas indagações marcaram o interesse do autor em convidar suas ex-professoras, Silvina Morales e Mariela Gutiérrez, para dialogar um pouco sobre isso.

\section{PRONUNCIAÇÃO, FLUIDEZ, SOTAQUE E MELODIA INTER- NA DE UMA LÍNGUA}

Há muitos brasileiros que buscam diminuir o forte acento português, aproximando-o, no mínimo, ao do espanhol neutro ou standard ${ }^{6}$.

Existem aqueles que logram uma pronúncia e acento idênticos aos dos hispanos. Esse fenômeno não é tão raro como se pensa. Apesar disso, alguns eruditos dizem categoricamente ser improvável chegar-se à perfeição linguística na língua-alvo. Na verdade, basta uma pesquisa rápida no Youtube para atestar que, sim, é possível. Talvez um dos casos mais emblemáticos seja o do norte-americano Dustin Luke, quem não possui raízes hispânicas, nem viveu

6 O espanhol neutro (também conhecido como castelhano neutro, espanhol global e espanhol internacional) é praticamente uma língua criada, ou melhor, recriada a partir do espanhol padrão que encontramos em gramáticas, dicionários e livros didáticos. Isso significa que funciona como uma nova forma estandardizada da língua, e exclui características linguísticas que são identificadas em variantes específicas a nível macro (mexicana, colombiana, etc.). O objetivo de tal configuração linguística salta aos olhos: fazer com que os meios de comunicação e entretenimento possam chegar (e vender) seus produtos ao máximo número possível de hispano-falantes. Pode ser definido como uma modalidade que nasce do castelhano e que tem fins comerciais em uma ampla área territorial. (disponível em: https://bujestraducoes.com. br/o-que-o-espanhol-neutro/) Acesso em 06.03.2021. 
por décadas em regiões de fala espanhola, mesmo assim fala absolutamente igual a um argentino ${ }^{7}$. Note-se que o que se discute aqui não é apenas o grau de fluidez, mas sim o chegar-se a um nível em que os próprios falantes nativos do idioma, em todas as situações, não descubram que tal pessoa é estrangeira.

Sobre o tema, pode-se indagar o seguinte: $\mathrm{O}$ que leva uma pessoa a ter mais facilidade no aprendizado de línguas do que outras? Ora, a mesma pergunta poderia ser levada aos que aprendem a tocar perfeitamente instrumentos musicais de "ouvido", isto é, sem nunca ter passado por escolas de músicas. Parece haver um dom inato em tais indivíduos, pois conseguem, sem aparentes dificuldades, chegar a utilizar um ou vários idiomas com pronunciação, fluidez, sotaque e melodia interna de uma lingua de maneira magistral.

Aqui, ver-se-á brevemente o que se entende por cada um de tais temas, começando-se por pronunciação, a qual pode ser definida como a forma, entonação, ritmo e intensidade acústica que uma palavra é realizada.

Neste sentido, está no campo das palavras tomadas em suas individualidades, buscando saber qual a intensidade das sílabas e onde a acento tónico recai. A palavra portuguesa anemia, por exemplo, possui quatro sílabas (a.ne. mi.a), e a ênfase recai na penúltima mi, embora esta não possua acento gráfico. A grafia em espanhol é a mesma, possuindo apenas três sílabas (a.ne.mia), sendo a sílaba tónica ne, embora também não haja sinal gráfico sobre ela.

Por seu turno, sotaque (ou tonada) pode ser compreendido como a forma "de pronunciar determinados fonemas em um idioma ou grupo de palavras. É a variante própria de uma região, classe ou grupo social, etnia, sexo, idade ou indivíduo, em qualquer grupo linguístico, e pode-se caracterizar por alterações de ritmo, entoação, ênfase ou distinção fonética” (Vortexmag, 2019, p. 01).

Assim, o sotaque diz respeito às variações internas de uma língua, inclusive aos seus dialetos, mas "é também o nome usado para a pronúncia imperfeita de um idioma falado por um estrangeiro. A variação do sotaque não depende apenas da região mas também da forma e condição social em que a pessoa vive" (Vortexmag, 2019, p. 02).

7 Isso pode ser comprado através do seguinte link: https://www.youtube.com/watch?v=_VdOp5q4gyo ou pelo livro:https://static0planetadelibroscom.cdnstatics.com/libros_contenido_ extra/34/33522_BienArgento_PrimerCap.pdf. Acesso em: 07.03.2021. 
No tocante ao que aqui se chama de melodia interna de um idioma, talvez um exemplo seja mais aclarador: um cidadão do Sul do país possui um sotaque diferente de um do Nordeste; no entanto no falar de ambos há um ritmo característico à língua portuguesa que é comum a qualquer região luso-falante. Um estrangeiro que ouça a ambos falando perceberá claramente que há uma mesma melodia, embora não consiga distinguir os sotaques. Toda língua possui essa melodia ou ritmo interno, entendido este como:

By rhythm in the psychological sense, is meant the perception of a series of stimuli as a series of groups. The successive groups are ordinarily of similar pattern and experienced as repetitive. Each group is perceived as a whole and therefore has a length lying within the psychological present (Woodrow apud Barbosa, 1994, p. 02).

Para outros, porém, o ritmo está ligado com a repetição e tem forte conotação psicológica:

Do ponto de vista da linguística cognitiva, podemos dizer que o ritmo é um modelo cognitivo idealizado (FERRARI, 2011, p. 50) controlado pelo frame espaço-tempo, por meio de um esquema imagético da repetição. Portanto, uma boa definição de ritmo, do ponto de vista cognitivo, é a expectativa da repetição. Todo objeto que ocorre seguindo um padrão repetitivo aciona a categoria ritmo na mente do indivíduo (Cagliari, 2012, p.05).

E é justamente este ritmo ou melodia interna que é uma das últimas coisas a se aprender no idioma-alvo. Não se deve confundi-lo com a fluidez, sobre a qual se dirão algumas palavras. O que é ser fluente em termos linguísticos? $\mathrm{O}$ conceito de fluidez pode ser bem representado pelo fluxo de um rio. As águas deste, antes de chegarem ao mar, devem superar uma série de obstáculos, como evitar montanhas, cruzar florestas, zonas áridas etc., porém o percurso é feito, e quanto mais o tempo passa mais as águas fluirão melhor, pois sua força e constância literalmente arrastaram tais obstáculos consigo. Ou seja, quanto mais pedras, obstáculos, no caminho, menor o grau de fluidez. Em termos linguísticos, assim se lhe define: "La fluidez, por su parte, puede definirse como la ha- 
bilidad de procesar (tanto en su recepción como en su producción) la lengua aspectos semánticos, morfosintácticos, socioculturales, etc. - con soltura y coherencia, sin excesivas pausas o titubeos y a una velocidad equiparable o próxima a la de los hablantes nativos”. (Instituto Cervantes, 2013, p. 280).

Por conseguinte, uma pessoa pode ter boa pronúncia na língua-alvo, ser fluído, ser compreendido por todos, mas ao falar deixar notar de imediato que não é nativo de tal língua. Por outro lado, um inglês pode ter uma pronúncia correta das palavras portuguesas, ser compreendido, mas ter um vocabulário pequeno, não ter nem fluidez, nem o ritmo melódico do português.

\section{AS FALAS DAS PALESTRANTES}

\subsection{Professora Silvina Morales: "Fluidez deve ser acompanhada de correção vocabular e semântica"}

Para muitos, fuência não é necessariamente sinônimo de correção linguística ou perfeição fonética. Uma pessoa que consiga pensar utilizando as estruturas sintáticas da língua, que possua determinados entraves, porém que estes não impeçam o fluir da mensagem, poderá ser considerada fluente. Assim, um brasileiro que já esteja falando inglês, mas que cometa erros, inclusive erros graves de sintaxe, concordância, mas consiga expressar-se será "fluído". Esse conceito é um pouco caótico, pois se um brasileiro que nunca houvesse estudado espanhol, poderia, desde o primeiro dia de aula, já ser considerado fluente na língua alvo. Isso porque um brasileiro falando possui uma estrutura sintática, lexical, semântica similar à do espanhol, e, embora com muitos entraves, lograria em alguns casos uma comunicação oral com determinados nativos. O grau de inteligibilidade entre essas duas línguas é alto, as estruturas sintáticas são semelhantes, o léxico é quase idêntico, a grande diferença é a fonética. Porém, se o brasileiro preferisse morar em um país espanhol, passaria por grandes dificuldades, já que sua "fluência" não o ajudaria nas atividades diárias, ele veria que nem todos teriam a predisposição para conversar pausadamente, lentamente com ele, ou seja, teria que aprender a entender o novo idioma. Do exposto, segue-se que o fato de haver inteligibilidade mútua não implica necessariamente fluência. 
Para a professora Silvina, pode-se considerar que uma pessoa fala fluentemente quando não tem erros consideráveis de pronúncia, fonética, estrutura sintática e lexical. Ou seja, ele tem erros ocasionais, não porque não os conhece, mas, por causa de situações pontuais, às vezes a pessoa fica nervosa, ansiosa ou apreensiva, o que pode confundi-la. Portanto, o grau de fluidez estaria irremediavelmente atrelado ao de correção vocabular, semântica e sintática. Durante a charla, a professora conceituou correção com base no Diccionario Cervantes de Términos Claves:

Por corrección se entiende la ausencia de errores en el uso de cualquiera de las destrezas lingüísticas - comprensión auditiva, expresión escrita, interacción oral, mediación, etc. [...] El concepto de corrección, ligado esencialmente a la gramática preceptiva, está profundamente arraigado en la lingüística, tanto la lingüística teórica como la aplicada a la didáctica de las lenguas. De hecho, la primera acepción que de gramática nos ofrece el DRAE es, precisamente: «Arte de hablar y escribir correctamente una lengua, y libro en que se enseña» (Instituto Cervantes, 2013, p. 280).

Entretanto, a correção não se limitaria apenas à gramática, pois existen otros tipos: corrección léxica, fonética, ortográfica, sociocultural, estilística, etc.La corrección, pues, abarca desde los aspectos más superficiales de la lengua hasta los más profundos, como son la estructuración de los textos, la coherencia, etc. El concepto adquiere unas dimensiones propias en la lengua oral, dado que ésta tiene una variación y unas características diferentes de la lengua escrita (Instituto Cervantes, 2013, p. 280).

Para reforçar seus argumentos, a referida professora apresentou a tabela sobre a fluidez oral ${ }^{8}$, abaixo exposta:

8 "El Marco Común Europeo de Referencia para las lenguas: aprendizaje, enseñanza, evaluación ${ }^{1}$ (MCER, o CEFR en inglés) ${ }^{2}$ es un estándar europeo, utilizado también en otros países, que sirve para medir el nivel de comprensión y expresión oral y escrita en una determinada lengua. El proyecto es el resultado de un trabajo iniciado en 1991 por iniciativa del gobierno federal suizo que estuvo inspirado en trabajos previos realizados por particulares e instituciones desde 1971. El documento final fue elaborado por el Consejo de Europa y presentado en 2001 durante la celebración del Año Europeo de las Lenguas”. (Fonte: Wikipedia). 
Tabela 1. Fluidez Oral

\section{FLUIDEZ ORAL}

Se expresa me diante un discurso amplio y saguido con ura fluidaz matural sin esforzarse ni ducar. Se detiene sólo para

C2 considerar las palatras más adecuadas con las que expresar sus persamientos o para buscar un ejemplo o explicación adeculach.

C1

Se expresa con fluidaz y es pontaneicad casi sin esfuer zo. Soblo un terma conceptualmente dificil puede obstaculiza h fluidaz ratural del discurso.

Se comunica espontín neamente, a menudo mostrando una fluidez y ura facilicad de expresión notables incluso en periodos más largos y complejos.

B2 Pr oduoa discursos con un rit mo bastante re gular, aunque pueda ducar mientras busca estuct uras y expresiones; provoca pocas pausas lag gas.

Participa en la conver sación con un gra do de fluidez y espontaneicad que hace posible b interacción tabitual con rablantes rativos sin produci tensión en ninguno de los inter locutcres.

Se expresa con rebtiva facilicad. A pesar da algunos problemas al formular su discursa, que dan como resultado pausas y ccallejones sin salidan, es capaz de segur a dearnte con ef icacia y sin ay uda.

B1

Es capaz de mantener su discuso, aunque sean muy evidentes las pausas para a derar la gamática y el léxico, y de corregirse; sobre todo, en periodos lar gos de produoción libre.

Se hace entender en inter venciones treves, aunqua resulten muy evidentes as pausas, as duchs inicales y b reformulación.

A2

Corstruye frases sotre temas cotidianos con la facilicad suficiente como para desenvolverse en treves inter cambios, a pesar da tener duclas muy evidentes y tr opiez os en el comienzo.

A1 Se desenvuelve con enunciados muy treves, aishdos y preparados, y con muchas pausas para buscar expresiones, articular palatras menos tabitulas y salvar la comunicación.

Fonte: Instituto Cervantes

O problema de tal tabela é que deixa em aberto um alta margem de subjetividade. Tome-se, por exemplo, o nível $\mathrm{C} 1$ descrito acima, pois se um brasileiro nativo estivesse a falar em uma reunião sobre um "tema conceptualmente difícil" e, de repente, se perdesse na fluidez do tema em questão, poderia ser considerado B2, pois neste o referido brasileiro "se comunica espontaneamente, a menudo mostrando uma fluidez y una facilidad de expresión notables incluso en períodos más largos e complejos". Outro ponto a observar é que a correção vocabular e semântica aí aparece como subsidiária da fluidez, o que daria margem para repensar o conceito de fluidez oral de um estudante brasileiro de espanhol A1. Neste ponto, poder-se-ia perguntar: 
como um brasileiro aprende espanhol? A resposta foi trazida pela outra convidada, cujo pensamento será abordado no próximo subcapítulo.

\subsection{Professora Mariela Gutiérrez: "O brasileiro aprende espanhol como se fos- se um nativo desta lingua”}

A professora Mariela Gutiérrez defendeu a seguinte tese: "Os brasileiros aprendem espanhol da mesma forma que os nativos de tal idioma: eles não pensam sobre as regras, apenas falam espontaneamente". Para ela, isso se explica devido à cercania morfossintática entre as duas línguas. Por isso, afirma que um luso-falante aprende mais facilmente o espanhol do que qualquer pessoa nativa de outra língua. Ou seja, se um alemão e um brasileiro resolvessem iniciar seus estudos em tal língua, este já teria uma vantagem "natural" em relação ao primeiro. Em suma, para ela, um brasileiro jamais é totalmente principiante no estudo do espanhol, pois, por mais que nunca o tenham estudado, ao iniciá-lo, já ingressa, por exemplo, em patamares equivalentes ou superiores ao A2 do (Quadro Europeu Comum de Referência para as Línguas), o qual classifica os estudantes de idiomas da seguinte forma:

Tabela 2: referências para as linhas línguas

Básico

\begin{tabular}{|l|l|}
\hline A1 & $\begin{array}{l}\text { É capaz de compreender e usar expressões familiares e cotidianas, assim como } \\
\text { enunciados muito simples, que visam satisfazer necessidades concretas. Pode } \\
\text { Iniciante }\end{array}$ \\
$\begin{array}{l}\text { apresentar-se e apresentar outros e é capaz de fazer perguntas e dar respostas } \\
\text { sobre aspectos pessoais como, por exemplo, o local onde vive, as pessoas que } \\
\text { conhece e as coisas que tem. Pode comunicar de modo simples, se o interlocu- } \\
\text { tor falar lenta e distintamente e se mostrar cooperante. }\end{array}$ \\
\hline B2 & $\begin{array}{l}\text { É capaz de compreender frases isoladas e expressões frequentes relacionadas } \\
\text { com áreas de prioridade imediata (p. ex.: informações pessoais e familiares } \\
\text { simples, compras, meio circundante). É capaz de comunicar em tarefas sim- } \\
\text { ples e em rotinas que exigem apenas uma troca de informação simples e direta } \\
\text { sobre assuntos que lhe são familiares e habituais. Pode descrever de modo sim- } \\
\text { ples a sua formação, o meio circundante e, ainda, referir assuntos relacionados } \\
\text { com necessidades imediatas. }\end{array}$ \\
\hline
\end{tabular}




\section{Independente}

\begin{tabular}{|l|l|}
\hline B1 & $\begin{array}{l}\text { É capaz de compreender as questões principais, quando é usada uma } \\
\text { linguagem clara e estandardizada e os assuntos lhe são familiares (temas } \\
\text { abordados no trabalho, na escola e nos momentos de lazer, etc.). É capaz } \\
\text { de lidar com a maioria das situações encontradas na região onde se fala } \\
\text { a língua-alvo. É capaz de produzir um discurso simples e coerente sobre } \\
\text { assuntos que lhe são familiares ou de interesse pessoal. Pode descrever } \\
\text { experiências e eventos, sonhos, esperanças e ambições, bem como expor } \\
\text { brevemente razões e justificações para uma opinião ou um projeto. }\end{array}$ \\
\hline $\begin{array}{l}\text { B2 } \\
\text { Usuário }\end{array}$ & $\begin{array}{l}\text { É capaz de compreender as ideias principais em textos complexos sobre } \\
\text { assuntos concretos e abstratos, incluindo discussões técnicas na sua área } \\
\text { de especialidade. É capaz de comunicar com certo grau de espontaneida- } \\
\text { de com falantes nativos, sem que haja tensão de parte a parte.É capaz de } \\
\text { exprimir-se de modo claro e pormenorizado sobre uma grande variedade } \\
\text { de temas e explicar um ponto de vista sobre um tema da atualidade, ex- } \\
\text { pondo as vantagens e os inconvenientes de várias possibilidades. }\end{array}$ \\
\hline
\end{tabular}

\section{Proficiente}

\begin{tabular}{|l|l|}
\hline $\begin{array}{l}\text { C1 } \\
\text { Proficiência } \\
\text { operativa eficaz }\end{array}$ & $\begin{array}{l}\text { É capaz de compreender um vasto número de textos longos e exigentes, } \\
\text { reconhecendo os seus significados implícitos. É capaz de se exprimir } \\
\text { de forma fluente e espontânea sem precisar procurar muito as palavras. } \\
\text { acadêmicos e profissionais. Pode exprimir-se sobre temas complexos, de } \\
\text { forma clara e bem estruturada, manifestando o domínio de mecanismos } \\
\text { de organização, de articulação e de coesão do discurso. }\end{array}$ \\
\hline $\begin{array}{l}\text { C2 } \\
\text { Domínio Pleno }\end{array}$ & $\begin{array}{l}\text { É capaz de compreender, sem esforço, praticamente tudo o que ouve ou lê. } \\
\text { escritas, reconstruindo argumentos e fatos de um modo coerente. É capaz } \\
\text { de se exprimir espontaneamente, de modo fluente e com exatidão, sendo } \\
\text { capaz de distinguir finas variações de significado em situações complexas. }\end{array}$ \\
\hline
\end{tabular}

Fonte: Instituto Cervantes

Para dita professora, nesta fase inicial os brasileiros inevitavelmente cometem erros sem maior transcendência, tal como dizer yo penso e yo jogo em vez de yo pienso e yo juego. No entanto, essas expressões são perfeitamente compreensíveis a qualquer hispano-falante. No mesmo sentido, o brasileiro aprenderia gírias e modismos hispânicos também de forma espontânea, tal qual, verbi gra- 
tia, o faria um brasileiro da região Sul que fosse viver no Nordeste: no começo haveria estranhamentos, porém nada demasiado difícil de superar.

No tocante à pronunciação, diz a professora, não há tampouco grandes problemas para os estudantes brasileiros: o que lhes causa mais dificuldade diz respeito ao alto grau de nasalização do português, sendo que o idioma espanhol possui poucos sons nasais, mas esse contratempo com prática poder-se-ia superar completamente. Nesse ponto existe um detalhe a observar: a professora está a referir-se a seus alunos, ou seja, àqueles regularmente matriculados em uma escola de idiomas, e geralmente com boa escolaridade, e que possuem uma equipe técnica preparada para ajudar-lhes. Assim, desde o porteiro da escola até o diretor, possuem bem claro a importância de falar lentamente, pronunciando todas as sílabas palavras etc. Estas escolas possuem pacotes turísticos e guias bilingues ou trilíngues, os quais também fazem esse papel de pedagógico, são treinados para falar claro, alto, devagar e educadamente ir mostrando pequenos erros no vocabulário e sintaxe. Neste contexto, pode o estudante até pronunciar mal muitas palavras que será entendido, mesmo porque a maioria dos seus professores estudou o português, entendendo e falando-o com relativa fluência. Se esses alunos nível B1, contudo, se atreverem a sair da zona de conforto e irem aos mercados mais distantes, a pegar ônibus, a tentar conversar com pessoas não tão dispostas, tolerantes ou pacientes para ouvir atentamente, perceberam o quanto sua pronuncia abrasileirada prejudica a comunicação. $\mathrm{O}$ que a professora insinua de fato é que um brasileiro, pela proximidade cultural, linguística, por possuir estruturas sintáticas semelhantes às dos nativos hispânicos, logra um bom grau de comunicação relativo a dados contextos e situações, porém as facilidades param por aí, pois se um brasileiro quiser avançar do nível B2 para o C2 terá que estudar bastante. Porém a preocupação com o acento e a fluidez é mais comum a professores de idioma e aos que vão fazer provas internacionais como o DELE'.

9 O DELE (Diploma de Espanhol como Língua Estrangeira) é o teste oficial de avaliação do grau de fluência em espanhol, emitido e reconhecido pelo Ministério da Educação, Cultura e Esporte da Espanha. O Instituto Cervantes é a instituição responsável pelos exames no Brasil, e a Universidade of Salamanca é a responsável pela elaboração, correção e classificação final do teste. 
A preocupação de grande parte dos estudantes estaria mais na fluidez do que na pronúncia ou correção morfossintática. Mesmo assim, os brasileiros atingiriam a fluência mais rápido do que os nativos de outros idiomas romances, como o francês e o italiano. É mais fácil para eles aprenderem o acento de Espanha do que da América, isso por questões geográficas e culturais.

Por tudo isso, ela apresenta métodos de ensino voltados para todos os tipos alunos. Afirma ser os estudos gramaticais importantes, porém devem estar contextualizados. Ademais, não devem ser levados em grande quantidade, principalmente se o público-alvo é infantil ou adolescente. Por essa perspectiva, afirma que as metodologias voltadas para o ensino de línguas estrangeiras podem enfocar:

Nas tarefas a realizar. Aqui, o foco estaria nos exercícios escritos: o estudante aprende as regras gerais do idioma, porém não há preocupação com a normatividade da gramática tradicional, e gradativamente vai sendo levado a situações de aprendizado de escuta e fala.

No conteúdo. O importante aqui não são os exercícios escritos em si, mas na temática abordada: a Segunda Guerra Mundial, por exemplo. Das quatro competências, preocupa-se mais com áudio-linguística: os estudantes são expostos a áudios e constante produção oral no idioma-objetivo e, por repetição, criam um hábito de falá-lo.

No estudante: por meio de dinâmicas de grupo: os estudantes praticam o idioma objetivo mediante a interação com os outros. Melhor para os adolescentes. Enfoca-se na fluidez e na comunicação clara. Busca temas da vida real cotidiana, é um método popular. Nem sempre se alcança exatidão na comunicação e se pode descuidar das habilidades de ler e escrever.

$\mathrm{Na}$ forma: temas gramaticais. Este seria mais para alunos avançados que desejam preparar-se para exames de proficiência.

Conclui a professora cusquenha: todos os métodos e técnicas são válidos, não há que se desprezar a nenhum, por isso, quanto ao tema, utiliza-se do que ela chama método eclético. De fato, deve-se levar em consideração as idiossincrasias e interesses dos estudantes, seu nível e rapidez no aprendizado. Há os que são mais auditivos, outros aprendem mais por livros didáticos, outros, mais extrovertidos, necessitam falar, por isso o professor deve balancear os mé- 
todos e as técnicas. Utilizar os recursos tecnológicos de ponta é importantíssimo, mas não deixar no ostracismo métodos aparentemente simples: como a cópia e o ditado, por exemplo. Tudo isso em sua porção e tempo certo pode ser útil para o aprendiz. Por isso, conclui a mestra, o professor deve saber quando usá-los isoladamente ou em conjunto com os demais.

\section{PODE-SE CONSEGUIR FLUÊNCIA EM SEIS MESES?}

É comum ouvir-se que uma língua estrangeira pode ser aprendida fluentemente em três meses, sobre isso existem vídeos no YouTube que tratam do assunto, porém é possível mesmo? Se sim, à qual tipo de fluência se referem? Como se viu na tabela sobre a fluidez oral, os conceitos não estão matematicamente livres de variadas interpretações. É por isso que se pode dizer ser quase impossível conseguir fluência equivalente aos níveis B2, C1, C2 em três ou seis meses. Sobre isso, Vergara diz:

Para ficar fluente em inglês ou qualquer outro idioma leva tempo. Lembra quando você era criança? Você não ficou fluente rapidinho. Quando você tinha 5 anos de idade conseguia se comunicar facilmente. Mas, pensa em quanto tempo você ficou em contato com o português desde que nasceu até se tornar fluente? É uma quantidade de tempo absurda. Por isso, a gente é tão fluente na nossa língua nativa, é uma habilidade da mesma forma que andar. Levando isso em consideração, dá para entender que só estudando 4 meses em uma escola ou em curso não tem como ficar fluente. Você pode ficar com uma base muito boa, pode conseguir ler em inglês, mas, ficar fluente exige mais tempo (Vergara, 2016, p. 01).

No entanto, o mesmo autor diz que há casos que nesse lapso de tempo é possível:

Você só se tornaria fluente em tão pouco tempo se já tivesse domínio de outras línguas e soubesse como aprender idiomas, se tivesse muito tempo livre e dedicasse muitas horas do seu dia ao estudo ou se fosse fazer um intercâmbio nos Estados Unidos e ficasse em contato com o inglês o dia todo. Nesses casos, daria para você ficar fluente em 4 meses. Mas, na maioria dos 
casos isso não acontece. E ser fluente é poder viajar para os Estados Unidos e poder se comunicar por conta própria. $\mathrm{E}$ isso você atinge em dois a três anos de estudo regular com um bom método (Vergara, 2016, p. 01).

Sobre isso, há que refletir-se um pouco mais detidamente. Existem relatos científicos de pessoas que sofreram um grave traumatismo craniano, desmaiaram, e, ao acordarem, perceberam que falavam outras línguas, como aconteceu com Ben McMahon, o qual depois de despertar do coma só conseguia falar chinês, segundo informa a BBC News. Entre os religiosos também é comum ouvir que alguns deles recebem o "dom das línguas" e, inspirados pela força do Espírito Santo, falam outros idiomas. Isso não é impossível. No entanto, essas são exceções. Perceba que Vergara diz que ficar fluente é poder viajar e "se comunicar por conta própria”, o que equivaleria ao nível B1 ou até o A2, ou seja, básico ao iniciante no intermediário. Quando os cursinhos de idiomas falam em fluência rápida, no fundo querem dizer que o indivíduo conseguirá entender o básico e falar com certa dificuldade: eles não se referem a ser proficiente, o que seria mais ou menos o nível C1 e C2. Então, proficiência significaria "competente e eficiente no que faz, capaz, preparado, conhecedor" (Saulo Júnior, 2019, p. 01). Contudo a ideia sub-reptícia que muitas dessas escolas passam é que o estudante não ficará apenas com o "basicão" no idioma-meta, mas sim proficiente, o que, em tal lapso de tempo é dificílimo. Em três ou quatro meses daria, como o próprio autor o aponta, porém diz ele que em raríssimos casos e com os seguintes pressupostos: a) já tivesse domínio de outros idiomas; b) soubesse como aprender idiomas; c) tivesse muito tempo livre; d) dedicasse muitas horas por dia ou fizesse intercâmbio. A estes, pode-se adicionar o "gênio".

No tocante ao gênio, existem pessoas que nascem assim. Quantas crianças não sonham em ser um grande jogador de futebol, quantas entretanto logram ser como Pelé ou Messi? As habilidades destes dois com a bola nos pés é fora do comum. E na literatura, quantas têm a grandeza de um Cervantes ou de um Machado de Assis? No campo da ciência, quantos Pitágoras ou Kepler existem? Homens como estes não são tão comuns na sociedade. Porém, além da genialidade, eles precisam de outros elementos para desenvolver suas habilidades, como 
contexto e vontade. Se Pelé tivesse nascido na China, provavelmente não teria o gosto nem os instrumentos ideais para jogar futebol. Além disso, se ele tivesse nascido no Brasil em uma classe rica, o futebol não seria a única forma para ele de alcançar o sucesso ou de ter uma vida economicamente. Isto é, mais do que jogar por prazer, o que o motivou também foi a necessidade. Quantas horas de sua vida não se dedicou ao treinamento e à luta por superar-se a si mesmo? $\mathrm{Ou}-$ tro gênio do futebol é Cristiano Ronaldo, que além de seu gênio tem uma dedicação quase fanática por manter-se em forma. No campo das línguas acontece o mesmo: há pessoas que aprendem línguas de ouvido, simplesmente, sem muito esforço, obtêm um sotaque quase perfeito, compreendem rapidamente as estruturas das línguas, etc. Nesse caso, um gênio, com esforço, pode atingir a fluência de um $\mathrm{C} 1$ ou $\mathrm{C} 2$ em seis meses ou menos, mas será muito difícil.

O outro caso é o do poliglota. Uma pessoa que fala várias línguas aprendeu a lidar com as dificuldades e pressões que a aprendizagem de uma língua causa terá, muito provavelmente, mais facilidades em conseguir um nível excelente na língua-alvo. A ansiedade ao tentar entender uma língua é enorme, já que o aluno começa a dedicar-se muito, em um frenesi constante. Mesmo neste caso, há uma dificuldade adicional. Como se sabe, as línguas são divididas em grandes famílias: português, espanhol, italiano, francês, etc. têm como uma de suas bases o latim. Todas possuem estruturas sintáticas e lexicais semelhantes, o que facilita muito o aprendizado dessas linguagens. Portanto, parece claro que alcançar a fluência nesses idiomas é mais fácil para um brasileiro do que para um inglês. Portanto, um poliglota que fala apenas línguas românicas terá mais dificuldade em aprender mandarim, por exemplo. $\mathrm{O}$ exemplo do poliglota é dado para quem já aprendeu várias línguas, inclusive aquelas diferentes de sua família linguística.

Quando o poliglota e o gênio são a mesma pessoa, ou seja, quando um indivíduo possui os métodos adequados, tem tempo e disposição, é disciplinado, dedica-se por dez horas ou mais de estudos diários e possui o dom inato para o aprendizado de idioma, então neste caso poderá sim chegar ao nível C2, ou seja, chegando ao grau de nível avançado, quase chegando ao grau de domínio pleno, chegando a falar como se fosse um nativo.

Fora esses casos, chegar à proficiência plena é coisa muito difícil. 


\section{CONSIDERAÇÕES FINAIS}

Do exposto, pode-se concluir que o ensino do espanhol para brasileiros requer uma atenção diferenciada, pois, apesar das semelhanças, pode oferecer a enganosa sensação de que o "espanhol é fácil”. Como se viu, é mais fácil para um brasileiro entender mais rapidamente tal língua do que para um alemão ou um chinês, por exemplo, porém isso não implica que seja facílimo para tal brasileiro chegar à fluência na língua de Cervantes. $\mathrm{E}$ foi isso que ambas professoras, no fundo, deixaram claro. A professora Silvina disse que a fluência está ligada diretamente à correção, seja vocabular, seja semântica; já a professora Mariela afirmou que o brasileiro aprende espanhol como se fosse um nativo, mas que, justamente por isso, possui um caminho longo para conseguir dominar todas as sutilezas do idioma espanhol, afinal um nativo leva anos e anos para dominar seu próprio idioma.

Ambas falaram da importância da gramática no estudo de línguas, embora disseram que esta é apenas uma ferramenta mais, não podendo ser utilizada como se fosse um fim em si mesma. De fato, elas têm razão. É importante frisar bem isso: o estudo das gramáticas no aprendizado de idiomas é de grande relevância, porém deve ser utilizado com parcimônia e cuidado.

O moderador da charla, entretanto, perguntou a ambas qual seria o papel da gramática na educação superior. A professora Silvina contestou que uma coisa é o estudo de línguas e outra bem distinta é a formação de professores. Neste ponto, ela foi bem incisiva na importância de se compreender a fundo a gramática normativa tanto do espanhol quanto do português, afirmando que um curso superior formará professores que deverão ter o domínio profundo tanto do idioma, da cultura e da literatura dos povos que falam a língua-alvo. Logo, o estudo das gramáticas (normativa, descritiva, gerativa, comparada, etc.) é de fundamental importância para o futuro professor, da mesma forma que um sólido conhecimento das literaturas e costumes dos povos estudados.

Em suma, não há que confundir-se estudo de idiomas com estudo superior de letras estrangeiras, pois nos dois casos há métodos e técnicas diferenciados e, principalmente, os objetivos são bem distintos. No primeiro caso 
o foco do estudante é apenas a fluência na língua-alvo, o que não está errado; já no segundo caso, além da busca da fluência, deve o estudante preocupar-se com temas mais aprofundados, tais como a história da língua, as diversas correntes literárias e, também, os estudos gramaticais superiores.

\section{REFERÊNCIAS}

ANDONINI, Giana. Dele: o teste oficial de proficiência em espanhol. Fundação estudar. (2013). Disponível em; https://www.estudarfora.org.br/dele-o-testeoficial-de-proficiencia-em espanhol/\#: :text=se\%20o\%20seu\%20destino\%20 for,cultura\%20e\%20esporte\%20da\%2 Acesso: 11 mar 2021.

BBC NEWS BRASIL. Acordei do coma e só sabia falar chinês. Edição de 23 de março de 2916. Disponível em: https://www.google.com.br/amp/s/www. bbc.com/portuguese/noticias/2016/03/160322_australiano_chines_mdb.amp Acesso: 11 mar 2021.

BARBOSA, Plínio Almeida. Revelar a estrutura ritmica de uma lingua construindo máquinas falantes: pela integração de ciência e tecnologia de fala. Revista Scarpa, E. Estudos de Prosódia. Campinas: Editora da Unicamp, pp. 21-52. Disponível em: https://www.unicamp.br/iel/site/docentes/plinio/EstudosProsodia.pdf Acesso em 10 mar 2021.

BUJES, Rosane. O que é o espanhol neutro. Bujes traduções. Disponível em: https://bujestraducoes.com.br/o-que-o-espanhol-neutro Acesso em 10 mar 2021.

CHARLAS SIN FRONTERAS. Dificultades y propuestas metodológicas: reflexiones acerca de la ensenanza de ele para brasilenos. Projetos Dale. Disponível em: https://www.youtube.com/watch?v=Hqs7EzWmSvA\&t=626s Acesso em 10 mar 2021.

CAGLIARI, Luiz Carlos. Linguas de ritmo silábico. Rev. Est. Ling., Belo Horizonte, v. 20, n. 2, p. 23-58, jul./dez. 2012. Disponível em: http://www. 
periodicos.letras.ufmg.br/index.php/relin/article/viewFile/2743/2698 Acesso em 10 mar 2021.

DUKE, Dustin. Bien argento. Kindle Edition. Disponível em: https://static0planetadelibroscom.cdnstatics.com/libros_contenido_extra/34/33522_BienArgento_PrimerCap.pdf Acesso em 10 mar 2021.

INSTITUTO CERVANTES. Diccionario de términos claves para ELE. Disponível em: https://cvc.cervantes.es/ensenanza/biblioteca_ele/diccio_ele/indice.htm Acesso em 10 mar 2021.

REVISTA VORTEXMAG. Lingua Portuguesa: os 10 sotaques mais dificeis de entender (Brasil e Portugal). 2019. Disponível em: https://www.vortexmag.net/ lingua-portuguesa-10-sotaques-mais-dificeis-de entender-brasil-e-portugal/ Acesso em 10 mar 2021.

SAULO JÚNIOR. O ser proficiente. Infopedia. 2019. Disponível em: https:// administradores.com.br/artigos/o-ser-proficiente Acesso em 10 mar 2021.

VERGARA, Mairo. Inglês fluente em 4 Meses? É possivel? 2016. Mairo Vergara. Disponivel em: https://www.mairovergara.com/ingles-fluente-em-4meses-e-possivel/ Acesso em 10 mar 2021. 


\section{CAPÍTULO 4. A IMPORTÂNCIA DA LITERATURA NAS AULAS DE E/LE}

Samuel Anderson de Oliveira Lima

"A literatura não diz que sabe alguma coisa, mas que sabe de alguma coisa;
ou melhor; que ela sabe algo das coisas - que sabe muito sobre os homens" (Roland Barthes, Aula, 2013)

\section{Introdução}

Ao longo dos anos, tem-se discutido sobre a importância da literatura no ensino básico, com o intuito de defender o papel essencial que essa ciência pode ter para a formação dos nossos alunos. Essa mesma discussão tem chegado às mesas dos docentes de espanhol como língua estrangeira, tendo em vista que há escassez de pesquisas que invistam nessa temática. Sabe-se que muitos Manuais de ensino de língua espanhola priorizam o aspecto linguístico, valorizando as questões gramaticais, textuais, fonéticas, etc., deixando de lado, muitas vezes, a valorização dos aspectos culturais e literários dos países hispânicos. Não estamos afirmando, porém, que todos os Manuais rejeitam a literatura, mas é fato consumado que em alguns deles o texto literário é usado como mero suporte para o ensino de questões gramaticais. Há outros, por outra parte, que fazem bom uso da literatura.

Neste texto, que é resultante de uma palestra proferida remotamente para o projeto "Charlas sin fronteras" da UNIR, pretendemos discutir/apresentar algumas estratégias que contribuam para a prática do ensino de literatura nas aulas de língua espanhola do ensino básico no Brasil. Para isso, nosso debate seguirá por três caminhos: primeiro, falaremos sobre a literatura em seu aspecto mais geral, sua importância, sua função, sob à luz de grandes teóricos; segundo, discutiremos sobre a importância da literatura no ensino e, particularmente, no ensino de ELE; por último, apresentaremos algumas propostas 
de aplicação didática que possam contribuir para o aprimoramento do ensino dessa disciplina nas aulas de língua espanhola do ensino básico.

\section{Uma questão de direito e de importância}

O que é literatura? Esse é o mote que nos dirige para abrirmos a discussão em torno da importância do ensino de literatura nas aulas de E/LE. Para responder essa interrogação, daremos voz a alguns críticos literários.

Antonio Candido, em seu célebre ensaio "O direito à literatura", nos fornece elementos suficientes para compreendermos o papel da literatura em nossas vidas. Sob o ponto de vista de Candido (2004), a literatura é arte, é criação e, portanto, é feita de imaginação, expressando a essência do coração humano. Literatura promove uma espécie de liberdade, aquela que permite ao autor dizer o que não pode ser dito nas ruas, tornando-se dessa feita "uma necessidade universal”. Acima de tudo isso, a literatura nos faz ser mais humanos, ela nos humaniza, nos liberta do caos: "a literatura desenvolve em nós a quota de humanidade na medida em que nos torna mais compreensivos e abertos para a natureza, a sociedade, o semelhante" (Candido, 2004, p. 180).

Esse texto de Candido nos permite refletir politicamente sobre a literatura, "afinal, ensinar literatura é sempre um ato político" (Perrone-Moisés, 2006, p. 29), no sentido de que ele a coloca como um direito essencial ao ser humano comparando-o a qualquer outro direito básico, como o direito à alimentação, à saúde, à habitação. E por que não direito à fruição? Candido (2004, p. 191) nos responde: "uma sociedade justa pressupõe o respeito dos direitos humanos, e a fruição da arte e da literatura em todas as modalidades e em todos os níveis é um direito inalienável”.

Em Literatura para quê? , Antoine Compagnon (2009, p. 47, grifos nossos), crítico literário francês, professor do Collège de France, acrescenta:

A literatura deve, portanto, ser lida e estudada porque oferece um meio alguns dirão até mesmo o único - de preservar e transmitir a experiência dos outros, aqueles que estão distantes de nós no espaço e no tempo, ou que diferem de nós por suas condições de vida. Ela nos torna sensíveis ao fato de que os outros são muito diversos e que seus valores se distanciam dos nossos. 
Chamamos a atenção para os verbos "preservar" e "transmitir". A literatura deve ser enxergada como meio de preservar a cultura de um povo, as raízes de uma nação e deve ser vista como mecanismo de transmissão dessa cultura. Através dela é possível enxergar o mundo do passado e do presente; nela, o leitor consegue ver o outro, suas experiências, suas condições de vida: "o texto literário me fala de mim e dos outros; provoca minha compaixão; quando leio eu me identifico com os outros e sou afetado por seu destino, suas felicidades e seus sofrimentos são momentaneamente os meus" (Compagnon, 2009, p. 48-49). Nesse mesmo texto, o crítico francês elabora uma série de questões que podem nortear nossas reflexões sobre a importância da literatura, vejamos: "Quais valores a literatura pode criar e transmitir ao mundo atual? Que lugar deve ser o seu no espaço público? Ela é útil para a vida? Por que defender sua presença na escola?" (Compagnon, 2009, p. 20). Para Ítalo Calvino (2019, p. 13), “há coisas que só a literatura com seus meios específicos nos pode dar", ou seja, ela deve ter um espaço de destaque no ensino e, consequentemente, no de língua espanhola.

Outro importante professor e crítico francês, Roland Barthes, em sua famosa Aula (2013, p. 17), afirma o que deve ser entendido por literatura: "entendo por literatura não um corpo ou uma sequência de obras, nem mesmo um setor de comércio ou de ensino, mas o grafo complexo das pegadas de uma prática: a prática de escrever”. Isto é, no dizer de Barthes, a literatura é uma prática, a de escrever, desconstruindo a crítica historicista que está muito mais preocupada em definir cartesianamente a sequência de obras e de autores, em seus mais diferentes estilos. Literatura, nessa visão, é mais que o comércio de livros das grandes editoras, mais que a preocupação com a vendagem de livros, sobretudo se estamos em consonância com o aspecto da fruição como vetor que move a produção literária desde os primórdios.

Jean-Paul Sartre (2004, p. 40) também traz uma definição de literatura, mas sob a alcunha do elemento livro: "assim, o livro não é, como a ferramenta, um meio que vise a algum fim: ele se propõe como fim para a liberdade do leitor". Nesse sentido, une-se ao pensamento de Antonio Candido quando afirma que a literatura liberta. Antoine Compagnon (2009, p. 50) segue nessa mesma 
linha de pensamento e alude que "a literatura nos liberta de nossas maneiras convencionais de pensar a vida [...]" e ainda acrescenta, na mesma página, que “a literatura desconcerta, incomoda, desorienta, desnorteia [...]". Por isso, urge promovermos o elogio da literatura ${ }^{1}$. Nós, professores, temos esse papel.

A professora, escritora e crítica literária brasileira Leila Perrone-Moisés, ex-aluna de Roland Barthes, nos dá sua contribuição para definirmos a literatura. Para ela, "a literatura é [...] uma prática de linguagem separada (e superior) das outras práticas verbais, uma arte e um meio de conhecimento específicos” (2016, p. 19). Barthes a havia definido como prática de escrever e Perrone-Moisés amplia para prática de linguagem, uma linguagem que está separada das demais e, portanto, agrega valor, destaca, separa. A literatura é uma linguagem especial, especializada, refinada, que leva o leitor para um meio diferente do que é lhe é comum, leva-o para um espaço alheio ao do cotidiano. Em sua visão, a literatura não conhece fronteiras geográficas: "[...] a boa literatura, embora contenha sempre as marcas do social e do nacional, não conhece fronteiras geográficas” (Perrone-Moisés, 2016, p. 77). Isto é, ela ultrapassa qualquer barreira.

Poderíamos agenciar outros críticos para seguirmos nessa definição, porém, os que aqui se apresentaram são pontuais e conseguem equalizar o conceito de literatura que também temos. Passaremos agora para a discussão sobre a literatura na sala de aula, especificamente, nas aulas de língua espanhola como língua estrangeira.

\section{Literatura como instrumento de formação}

A literatura é um poderoso instrumento de instrução e educação, razão pela qual há uma necessidade perene de que nós professores reflexionemos sobre o papel da literatura em nossas aulas de E/LE.

A primeira reflexão consiste no fato de a literatura ser enxergada como desfrute. Antes de ser professor, devemos ser leitores. O professor que não sente prazer pela leitura não poderá ser um bom professor de literatura. Como poderá incentivar seus alunos ao hábito da leitura? Como fará deles bons leitores? Umberto Eco (2017, p. 9-10), falando sobre a função da litera-

1 O livro O elogia da literatura (2020), de Bauman e Mazeeo, trazem essa perspectiva. 
tura, afirma que esta é um conjunto de "textos, además, que se leen por deleite, elevación espiritual, ampliación de conocimientos, incluso por puro ocio, sin que nadie nos obligue a hacerlo". Sendo assim, o primeiro contato com o texto literário precisa ser via deleite, afinal, o objetivo primeiro da literatura é a fruição. Além do mais, o crítico italiano considera que a literatura deve ser lida como elevação espiritual, ou seja, como passo para a transcendência. Dessa forma, estaria circunscrita no campo das ideias que estão além dos nossos limites humanos, materiais, portanto, metafísica.

Para Martínez (2012, p. 11), por sua vez, “[...] muchas veces el uso o no del texto literario depende del perfil del profesor, de su experiencia vital, de su modelo de aprendizaje, de sus gustos, de si lee o no lee, de si le interesa o no la literatura, etc." Consideramos fundamental essa reflexão, haja vista termos nela um olhar que contribui para o pensamento de que o professor pode negar-se a dar aulas de literatura, justamente pelas razões elencadas por Martínez. É preciso levar em consideração essas questões cruciais para o sucesso do ensino de literatura. Nem todo professor é um bom leitor, talvez não lhe interesse a literatura. Nesse sentido, podemos elaborar as seguintes questões: por que estudar literatura? Por que ensinar literatura? Qual a função da literatura? No intuito de tentar equacionar esses questionamentos, convocamos mais uma vez à baila a crítica Perrone-Moisés (2016, p. 80), quando ela argumenta:

[...] ensinar literatura é ensinar a ler e, nas sociedades letradas, sem leitura não há cultura; porque a capacidade de leitura não é inata, mas adquirida; porque os textos literários podem incluir todos os outros tipos de texto que o aluno deve conhecer, para ser um cidadão apto a viver em sociedade; porque os textos literários são aqueles em que a linguagem atinge seu mais alto grau de precisão e sua maior potência de significação; porque a significação, no texto literário, não se reduz ao significado (como acontece nos textos científicos, jornalísticos, técnicos), mas opera a interação de vários níveis semânticos e resulta numa possibilidade teoricamente infinita de interpretações; porque a literatura é um instrumento de conhecimento do outro e de autoconhecimento; porque a literatura de ficção, ao mesmo tempo que ilumina a realidade, mostra que outras realidades são possíveis, libertando o 
leitor de seu contexto estreito e desenvolvendo nele a capacidade de imaginar, que é uma necessidade humana e pode inspirar transformações históricas; porque a poesia capta níveis de percepção e de fruição da realidade que outros tipos de texto não alcançam.

Citação de muito fôlego que nos mostra as razões pelas quais é imprescindível o ensino de literatura nas nossas aulas. Precisamos valorizá-la e estudá-la. E a mesma Perrone-Moisés (2016, p. 80) nos diz por que estudar a literatura:

Estuda-se literatura porque ela contém conhecimentos, e estes podem ser confrontados com os que nos dão a filosofia e as ciências. Estuda-se literatura porque ela nos dá uma visão mais aguda do real, que pode ser confrontada com a visão sociológica, histórica, psicanalítica. Estuda-se literatura porque ela desautomatiza e valoriza os usos da linguagem verbal, o que pode ser aferido com o auxílio da linguística, da semiótica, da retórica, da estilística. Mas seu estudo não deve ser reduzido e circunscrito a nenhuma das formas de conhecimento enumeradas.

A literatura, podemos considerar e reforçar, abre portas para que o aluno tenha acesso à cultura, razão pela qual o professor deve refletir sobre sua função na sala de aula, afinal "a literatura serve para rir, para chorar, para viajar, para assombrar, para pensar, para compreender e, sobretudo, para nos encantar com o fato de que a linguagem verbal seja capaz de tudo isso e mais um pouco" (Perrone-Moisés, 2016, p. 82). Dessa forma, os professores de língua espanhola devemos tratar com cuidado o planejamento das aulas com o fim de inserir o ensino de literatura como ferramenta importantíssima para o sucesso educacional. Não se deve pensar que por se tratar de aula de língua espanhola, o professor só deva ensinar as questões linguísticas, "en el campo de ELE lo deseable sería tratar de imbricar la lengua y la literatura, defender la conexión lengua-literatura como función formativa y aprendizaje lingüístico-comunicativo" (Martínez, 2012, p. 15). Muitos professores podem pensar que a literatura é uma disciplina que está distante das questões comunicativas, que como o objetivo central no ensino de ELE é o aspecto comunicativo, não deve - por uma questão de tempo - trabalhar com algo que esteja distante dessa abor- 
dagem. No entanto, como vimos através de várias reflexões teórico-críticas acima, a literatura pode proporcionar o diálogo com vários mundos, científicos e imaginários, nela estão imbricadas as formas culta e coloquial da língua, e, portanto, deve estar presente no processo de ensino-aprendizagem, conforme pode atestar Begoña Martínez (2012, p. 16):

La lengua literaria no está necesariamente desligada de las formas y funciones del habla cotidiana. No podemos verla como una producción aparte, inusual y para exquisitos. Por el contrario, en ella coexisten muestras de discurso coloquial junto a conversaciones propias de los géneros literarios.

Para tentar suprir uma lacuna - a literatura - no ensino de espanhol como língua estrangeira nas aulas da educação básica no Brasil, endossamos o valor que ela tem para uma aprendizagem mais significativa. Para isso, na próxima seção, apresentaremos algumas propostas de aplicação didática para serem usadas nas aulas e servem, sobretudo, como uma mostra do que e de como os professores podem trabalhar literatura em suas aulas, levando em conta, sem dúvidas, todas as questões logísticas a que estão submetidos em seu dia a dia profissional.

\section{Propostas de aplicação didática}

À luz do que Begoña Martínez (2012) expõe em seu artigo, elaboramos algumas estratégias que podem levar os professores de ELE a planejar suas aulas. Para esse fim, pensamos, de acordo com as discussões que já foram levantadas neste texto, promover o diálogo entre a literatura e as outras ciências: literatura e pintura, literatura e teatro, literatura e semiótica, literatura e cinema. A partir daí, os professores podem tomar como exemplos e criar novas estratégias, usar outros recursos, ver outras obras, tudo vai depender do ambiente, da turma, do nível. É preciso levar em consideração aspectos que são essenciais para o êxito do processo de ensino-aprendizagem. No caso da literatura, precisamos pensar a escolha dos livros que levaremos para a sala de aula. Segundo Martínez (2012, p. 17), os livros precisam ser claros, atraentes, com "textos que revelen algo significativo a nuestros lectores, despierten su interés y las ganas 
de interactuar”. Além disso e associado a essa seleção, o professor deve refletir sobre quais conteúdos serão ensinados e isso não deve ser feito como num jogo de loteria, é preciso "plantearse qué objetivos queremos alcanzar, qué contenidos queremos desarrollar y qué recursos vamos a emplear para conseguirlo. Y todo ello, ha de estar en perfecta conexión con el nivel de lengua y la capacidad lectora de los alumnos" (Martínez, 2012, p. 17).

Para a primeira proposta de diálogo entre a literatura e a pintura, escolhemos trabalhar com a obra Celestina, de Fernando de Rojas. Embora seja uma obra do século XV, portanto, com uma linguagem temática bem distante da realidade dos nossos alunos, podemos perfeitamente aproximá-los desse novo contexto social. Não podemos esquecer que os clássicos têm uma importância fundamental para a formação e consolidação de uma sociedade, como nos assegura Ítalo Calvino (2020). É claro que uma das dificuldades consistirá na linguagem da obra, tendo em vista que foi escrita em um espanhol medieval e, portanto, não motivará a leitura pelos alunos. Nesse caso, podemos trabalhar com obras que tenham o espanhol atualizado e mesmo, a depender do nível dos alunos, trabalhar com obras adaptadas. Mas, é preciso ter cuidado com essas adaptações, o professor terá de selecionar uma boa adaptação, pois ela será um condutor para o texto original.

No caso do livro Celestina, ele se configura como uma obra que apresenta características de um processo de transição entre a Idade Média e o Renascimento. Sua história está marcada pela formação social dos núcleos dos personagens e se concentra nas ações da alcoviteira Celestina que trabalha para unir o casal Calisto e Melibea.

A personagem Celestina tem características que vão marcar a sociedade espanhola da época e terá grande destaque na crítica literária, por essa razão, será lida por outras expressões artísticas, como a pintura. Picasso, pintor moderno espanhol, a pinta em 1903, e é com essa pintura que iremos trabalhar nossas atividades literárias.

Sendo assim, propomos as seguintes atividades: o professor levará a pintura de Picasso para a turma e proporá que os alunos façam uma descrição daquela mulher ali representada, buscando descrever seus traços físicos. Dessa forma, 
estará trabalhando com expressão oral e expressão escrita, motivando os alunos a aprender o léxico que se usa para fazer uma descrição. Além disso, poderá propor que, a partir dessa descrição, os alunos possam refletir sobre quem seria essa mulher, um personagem de um livro? Uma atriz de teatro medieval? Sua história estaria em um livro antigo ou contemporâneo? Após esse exercício, o professor disponibilizaria o livro para que os alunos fizessem a leitura. Feito isso, num próximo encontro, seria o momento de comparar a descrição que eles tinham feito da pintura de Picasso e as hipóteses levantadas por eles sobre a personagem e como ela se configura de fato na obra. Deve-se destacar que essa atividade pode ser realizada com o auxílio de outras disciplinas, como arte e história.

Para trabalhar com literatura e teatro, pensamos na seguinte atividade: o professor escolhe uma obra teatral, nesse caso, escolhemos Bodas de sangre, de Federico García Lorca, uma obra do século XX, e a leva para que os alunos façam a leitura. Fica implícito que é preciso fazer uma ambientação, apresentar o autor, o contexto, as técnicas do teatro, inclusive mostrando as diferenças entre um romance e um texto teatral.

No texto de Lorca, entre outras coisas, o tema que pode ser trabalhado é o flamenco. Nesse sentido, após a leitura dos alunos, o professor deverá preparar uma aula para apresentar esse tema, com o intuito de fazer os alunos conhecerem a importância do flamenco para a Espanha e para a região da Andaluzia, onde nasceu o autor da obra. Aí, já temos a literatura promovendo contato com a cultura de um lugar. Em seguida, o professor pode trabalhar com produção escrita e pedir para os alunos criarem um final diferente para a peça; pode formar grupos ou dividir a turma em dois grandes grupos e cada um deverá criar um novo final para a história. Depois, esses mesmos grupos poderão encenar o que criaram. Para isso, o professor de literatura poderá ter o auxílio do professor de artes.

Essa peça foi filmada por Carlos Saura e o professor pode oportunizar aos alunos o contato com esse veículo e pensar numa atividade de expressão oral, em que grupos irão expor a impressão sobre o filme e, acrescentado a isso, deverão observar as diferenças entre a história narrada no filme e a que é narrada na peça, buscando esclarecer se todos os personagens estão presentes, se 
são as mesmas cenas, se o filme contribui para esclarecer ou esconder coisas da obra literária, entre outras questões.

Um terceiro diálogo que estamos propondo é entre literatura e semióticanão se trata de usar o nome "semiótica" com os alunos, pois não há necessidade de estabelecer essa discussão com eles, o professor pode dizer que é um diálogo entre literatura e imagética, por exemplo. $\mathrm{Na}$ nossa proposta, voltaremos ao passado literário novamente, pois escolhemos trabalhar com Lazarillo de Tormes, obra anônima do período renascentista, publicada originalmente em 1554.

A questão imagética é muito importante para motivar os alunos. Percebam que nas duas propostas anteriores estamos sempre trazendo o visual como suporte para o processo de ensino-aprendizagem. Nessa terceira proposta, a ideia é dar mais destaque a essa questão. Como se trata de uma obra escrita no século $\mathrm{XV}$, temos à disposição uma boa quantidade de edições diferentes que podem ser usadas para o exercício de interpretação semiótica, que seguiria os seguintes passos: primeiro o professor deve escolher algumas edições diferentes da obra; escolhemos a que foi publicada em 1554, a editada por Eduardo Alonso de 2007 e uma de 2006, editada por Rosa Navarro Durán. Essas capas devem ser apresentadas aos alunos antes que eles leiam o texto. $\mathrm{O}$ professor deverá pedir aos alunos que contem oralmente que tipo de narrativa poderá estar naqueles livros só pelo que está desenhado nas capas. É preciso levar os alunos a observarem todos os detalhes, questionando quais figuras aparecem, como estão dispostas, o que carregam, qual é o cenário, trata-se de um ambiente contemporâneo, rural, urbano. Em seguida, passa-se à leitura. Logo após, volta-se para constatar se aquilo que os alunos observaram na leitura das capas está contido na história contada.

No campo da pintura, também teremos retratadas cenas do Lazarillo de Tormes. Então, o professor pode pedir que os alunos façam uma pesquisa sobre pinturas que tragam cenas dessa obra e apresentem o resultado na sala de aula. Como exemplo, o professor pode apresentar o quadro "Lazarillo de Tormes" que foi pintado por Francisco de Goya, pintor espanhol, entre 1808-1812, o qual mostra Lázaro e o cego sentados em uma das cenas descritas pelo narrador. Nessa, o cego põe os dedos na boca de Lázaro a fim de encontrar algo que vai desmascarar o pobre menino que só fazia as trapaças para poder aplacar sua fome. 
Um aspecto muito importante que pode ser discutido com os alunos, após todas essas atividades, é promover a discussão sobre o tema da fome, falar sobre as questões sociais que estavam nas cenas cotidianas da Espanha do Siglo de oro e trazer para a realidade atual. Pode o professor pedir que os alunos criem pequenas histórias cujos personagens tenham algum tipo de semelhança com Lázaro, podendo ambientá-las no período contemporâneo ou mesmo no passado. Estaríamos assim dando vazão à criatividade de cada aluno e proporcionando que eles também produzam literatura. Pode até pensar em um concurso das melhores histórias e, quiçá, reuni-las em um livro que poderia ser distribuído entre as outras turmas, motivando a que leiam e escrevam em espanhol.

Nosso último diálogo é o de literatura e cinema. É sabido que muitas obras literárias são adaptadas para o cinema, como já vimos com Bodas de sangre. Dessa forma, o professor de língua espanhola tem várias possibilidades para trabalhar com esse diálogo. Para exemplificar, podemos trabalhar com o livro Como agua para chocolate da escritora mexicana Laura Esquivel, publicado em 1989, que depois se transformou em filme homônimo em 1992. O livro traz doze receitas de comidas mexicanas, uma para cada mês do ano.

Nessa atividade, propomos que partamos da exibição do filme. Primeiro, os alunos deverão assistir ao filme, fazer anotações, observar a ação dos personagens e dar atenção especial às receitas que são feitas. Em seguida, eles deverão ler o romance. Como exercício, eles podem escrever um relato explicativo das diferenças encontradas entre a história no filme e no romance: há diferenças entre as histórias? Que aspectos são destacados no filme? Houve alguma mudança com relação ao que é contado no romance? Foram retiradas cenas? Houve alguma mudança das receitas?

Para culminar, a turma pode ser dividida em 12 grupos e cada um deles deverá fazer uma das receitas que está no livro. A turma poderá realizar uma feira gastronômica mexicana e convidar outros grupos para compartilhar. Cada grupo deverá contar curiosidades da receita que fizeram; os alunos podem pesquisar sobre a localidade do México em que ela surgiu, se ainda pertence àquela sociedade, etc. Como se trata de comida estrangeira, muitas vezes não se conseguem os ingredientes necessários, então, os alunos podem pensar em algo que possa substituir o ingrediente faltante e depois poderão explicar porque fez tal substituição. 
É preciso deixar claro que se tratam de sugestões para o trabalho com a literatura em sala de aula. Os professores devem levar em consideração o nível de seus alunos, a idade, o ambiente; enfim, deve ter em conta muitas questões para a escolha da(s) obra(s) que quer trabalhar em sala de aula. $\mathrm{O}$ que pretendíamos era poder apresentar um texto que nos levasse a afirmar que é possível sim trabalhar com literatura e que isso pode ser algo motivador para a aprendizagem. Além disso, queríamos demonstrar o prazer que a literatura proporciona a seus leitores, levando-os, por conseguinte, a viajar pela leitura e pelo mundo da literatura.

\section{Conclusões}

Como palavras finais, queremos que o leitor enxergue a literatura como uma prática transcultural, uma prática transdisciplinar, pois "os valores do espírito e da cultura são indissociáveis dessa arte verbal que é para nós a literatura" (JOUVE, 2012, p. 31). Não é possível, na conjuntura atual, pensar a literatura como uma prática distante das outras artes. Precisamos cada dia levar nossos alunos a estabelecer fios de ligação entre as leituras literárias e a vida que os cerca, pois muito da nossa realidade vem sendo contado pelas penas dos autores.

O ensino de línguas estrangeiras, em especial o espanhol, passa por um momento de crise no nosso país, tendo em vista a derrubada da lei 11.161/2005 que a punha como disciplina obrigatória no ensino básico. Com a não obrigatoriedade, cada dia vemos as escolas retirarem de seus currículos a disciplina de espanhol e com isso retirando o emprego dos nossos professores. Essa realidade cruel tem afetado também o ingresso de novos alunos nos cursos de letras espanhol haja vista o mercado de trabalho estar cada vez mais escasso. Por essa razão, precisamos lutar pelo retorno da obrigatoriedade do espanhol a nível nacional para que possamos proporcionar à sociedade um contato com a cultura hispano-americana, nossa irmã.

O fato de haver uma certa desvalorização do ensino de espanhol nas escolas tem feito com que a carga horária, naquelas que ainda há a oferta, tenha diminuído bastante, restringindo-se a, muitas vezes, um horário de 50 minutos por semana. Daí, vem o grande desafio dos nossos professores de conseguir 
dar conta de um conteúdo tão vasto em tão pouco tempo. Esse cenário leva, portanto, ao esquecimento do ensino de literatura nas aulas de espanhol, que corrobora com seu esquecimento na sociedade como um todo, já que as pessoas estão muito mais afeitas às tecnologias, às séries, às novelas televisivas do que à leitura. A leitura do texto literário é relegada ao segundo plano.

Neste texto, buscamos, junto a grandes especialistas, mostrar a importância da literatura para a sociedade, tratando-a como um direito humano que não pode ser relegado. Todos têm o direito à literatura. Nosso grito deve ser "literatura para todos" como nos apregoou Perrone-Moisés (2006). Se todos têm esse direito, nós professores não podemos furtá-lo a nossos alunos. Mesmo que tenhamos muito pouco tempo nas aulas de espanhol, precisamos traçar estratégias para oferecer o contato com a literatura do mundo hispânico, pois, através dela, muitos outros saberes advirão.

Nossa intenção, no encalço dessa valorização, foi apresentar quatro propostas didáticas que pudessem ajudar os professores no planejamento das aulas. Trata-se de ideias que podem ser tidas como iniciantes para uma dar partida na valorização do ensino de literatura. Certamente, se bem planejadas, as aulas com literatura se tornarão mais atrativas, instigantes e farão com que os alunos se sintam motivados a aprender mais sobre o mundo hispânico e consigam desconstruir a imagem preconceituosa que muitas vezes é inculcada na mente deles.

Além disso, nas propostas apresentadas, apresentamos duas obras clássicas e duas contemporâneas e como vimos é perfeitamente possível trabalhar com obras antigas; basta que o professor saiba introduzi-las nas aulas. $\mathrm{O}$ professor precisa ser criativo, usar de estratégias motivadoras e que faça com que aquilo que está ensinando tenha sentido, seja significativo para seus alunos. De nada adianta levar um texto do século XVII, como Don Quijote de la Mancha, e não dar significado aos alunos, fazendo-os entender o universo de coisas que estão envolvidas nessa narrativa. Rildo Cosson (2014, p. 17) tece considerações acertadas sobre o que provoca em nós boas experiências literárias:

A experiência literária não só nos permite saber da vida por meio da experiência do outro, como também vivenciar essa experiência. Ou seja, a ficção feita palavra na narrativa e a palavra feita matéria na poesia são processos formativos tanto da linguagem quando do leitor e do escritor. 
Uma e outra permitem que se diga o que não sabemos expressar e nos falam da maneira mais precisa o que queremos dizer ao mundo, assim como nos dizer a nós mesmos.

É essa experiência que devemos levar para nossos alunos, porque as obras literárias nos carregam para um mundo transcendental e na literatura encontramos também nosso mundo, este com o qual contribuímos e aquele no qual nos submergimos. Para finalizar, sem conseguir colocar ponto final, deixamos uma citação de William Marx (2020, p. 206-207) que define/resume o papel preponderante da literatura em nossas vidas:

As obras literárias falam do mundo, dos homens, dos deuses, da política, do coração e dos sentimentos, das lembranças e do futuro, do que nunca existiu e jamais existirá, do que ainda pode acontecer. Elas invocam os deuses, os fazem aparecer e se transportar no tempo, no espaço e no espírito, tratam os doentes, curam os processos, envenenam os saudáveis, exibem os ricos de mãos vazias e os enriquecem, derrubam os poderosos de seu trono e assim os mantém, elevam os humildes ou então os rebaixam. Elas criam numerosos universos, novas cidades, renomeiam a realidade, a transformam, a abolem, a idealizam, a deixam intacta. Elas me fazem existir, me introduzem na intimidade de meu leitor em mil lugares e mil anos daqui, fundam e destroem comunidades invisíveis a amizades reais. Elas imortalizam esta árvore nua diante de minha janela, esse canto de pássaro que ouço no coração do inverno, o azul frio do céu, o clique deste teclado sobre o qual digito com frenesi o que se torna o final deste livro. Elas dizem sobre o cansaço e a energia, o preto e o branco, o claro e o escuro, o bem e o mal, o macio e o duro, o alto e o baixo, o amor e o ódio, o tudo e o nada. Resumindo, elas continuam a fazer tudo o que lhe foi proibido e recusado durante séculos, no curso de infinitos litígios; e fazem ainda mais, que não temos a menor ideia, e que se descobrirá muito mais tarde - ou jamais.

A literatura deleita, instrui, educa, ensina, afinal a máxima jesuítica docere cum delectare (ensinar com prazer) deve ser o guia para qualquer professor, de qualquer disciplina, pois a literatura tem uma "función educativa que no se reduce a la transmisión de ideas morales, ya sean buenas o malas, o a la for- 
mación del sentido de la beleza" (ECO, 2017, p. 21). Ensinemos com prazer, façamos com que a literatura provoque nos alunos uma aura de gozo e alegria, mas com a consciência de que ela diverte, mas diverte perigosamente.

\section{Referências}

BARTHES, Roland. Aula. Trad. Leyla Perrone-Moisés. 1. ed. 16. reimp. São Paulo: Cultrix, 2013.

BAUMAN, Zygmunt; MAZZEO, Riccardo. O elogio da literatura. Trad. Renato Aguiar. Rio de Janeiro: Zahar, 2020.

CALVINO, Ítalo. Seis propostas para o próximo milênio. Trad. Ivo Barroso. 3. ed. 13. reimp. São Paulo: Companhia das Letras, 2019.

CALVINO, Ítalo. Por que ler os clássicos. Trad. Nilson Moulin. 1. ed. 8. reimp. São Paulo: Companhia das Letras, 2020.

CANDIDO, Antonio. El derecho a la literatura. In: Ensayos y comentarios. Trad. Rodolfo Mata Sandoval e María Teresa Celada. Campinas-SP: Editora da UNICAMP; São Paulo: Fondo de Cultura Econômica de México, 1995. p. 149-173.

CERVANTES, Miguel de. Don Quijote de la Mancha. Madrid: Santillana Ediciones Generales, 2004. (Edición del IV Centenario).

COMPAGNON, Antonie. Literatura para quê? Trad. Laura Taddei Brandini. Belo Horizonte: Editora da UFMG, 2009.

COSSON, Rildo. Letramento literário: teoria e prática. 2. ed. 4. reimp. São Paulo: Contexto, 2014.

ECO, Umberto. Sobre literatura. Trad. Helena Lozano Miralles. Buenos Aires: Sudamericana, 2017. 
ESQUIVEL, Laura. Como agua para chocolate. Buenos Aires: Delbosillo, 2014.

G. FERNÁNDEZ, Sonio Inez. Ensinar/aprender espanhol entre brasileiros: visão transcultural. In: SEDYCIAS, João (org.). O ensino do espanhol no Brasil: presente, passado, futuro. São Paulo: Parábola Editorial, 2005. p. 97-128.

GARCÍA LORCA, Federico. Bodas de Sangre. 2. Ed. Buenos Aires: Longseller, 2005.

JOUVE, Vicent. Por que estudar literatura? Trad. Marcos Bagno e Marcos Marcionilo. São Paulo: Parábola, 2012.

Lazarillo de Tormes. Prefacio Gregorio Marañón. Edición Víctor García de la Concha. Madrid: Editorial Espasa Calpe, 2006.

MARTÍNEZ, Begoña Sáez. La literatura en la enseñanza de ELE o el día en que Cervantes renunció a ser profesor de español en China. In: Actas del XIX Seminario de Difilcutades Especificas de la Enseñanza del Español a Lusohablantes: la literatura en la enseñanza del español como lengua extranjera, São Paulo, 22 de septiembre de 2012. Brasília: Embajada de España em Brasil - Consejería de Educación, Ministerio de Educación de España, 2012. p. 9-22.

MARTÍNEZ, Pierre. Didática de linguas estrangeiras. Trad. Marcos Marcioni1o. São Paulo: Parábola Editorial, 2009.

MARTÍNEZ-CACHERO LASECA, Álvaro. La enseñanza del español en el sistema educativo brasileño. Edición bilingüe. Brasília: Thesaurus, 2008. (Colección Orellana, 19).

MARX, William. Ódio à literatura: uma história da "antiliteratura". Trad. Humberto Pereira Silva. Jundiaí, SP: Paco Editorial, 2019.

NASCIMENTO, Magnólia Brasil Barbosa. Las relaciones entre la enseñanza de una lengua extranjera y su literatura. Anuario brasileño de estudios hispánicos, n. 1, Madrid, p. 139-145, 1990. 
PERRONE-MOISÉS, Leila. Literatura para todos. Literatura e sociedade, São Paulo, n. 9, p. 17-29, 2006.

PERRONE-MOISÉS, Leyla. Mutaçôes da literatura no século XXI. São Paulo: Companhia das Letras, 2016.

ROJAS, Fernando de. Celestina. Edición de Pedro M. Piñero. Madrid: Editorial Espasa Calpe, 2007.

SARTRE, Jean-Paul. Que é a literatura? Trad. Carlos Felipe Moisés. 3. ed. 2. reimp. São Paulo: Ática, 2004.

SEDYCIAS, João. Por que os brasileiros devem aprender espanhol? In: SEDYCIAS, João (org.). O ensino do espanhol no Brasil: presente, passado, futuro. São Paulo: Parábola Editorial, 2005. p. 35-44. 


\section{CAPÍTULO 5. REFLEXÕES ACERCA DAS LIVES OFERTA- DAS SOBRE TRADUÇÃO NO CHARLAS SIN FRONTERAS: NECESSIDADE, PERSPECTIVAS E/OU EXPECTATIVAS}

Mirella Nunes Giracca

\section{Introdução}

$\mathrm{O}$ projeto Charlas sin Fronteras surgiu em meio à pandemia com o propósito de aproximar docentes e discentes. No entanto, esse evento tomou proporções que foram além do ambiente puramente universitário à medida que ampliou horizontes e expôs a Universidade Federal de Rondônia (UNIR), abrindo portas e janelas para que o curso de Letras Espanhol da UNIR ganhasse destaque e reconhecimento em relação aos eventos ofertados durante o ano de 2020 no contexto brasileiro.

Por meio do Programa de Extensão "Trânsitos, Fronteiras, Migração e Línguas Adicionais na Amazônia", o projeto Charlas sin Fronteras foi ofertado gratuitamente na modalidade online. Além disso, o projeto se propôs a ofertar lives com o objetivo de promover conversas sobre diferentes temas relativos à Língua Espanhola e às culturas dos países hispano-falantes. Além disso, essas lives também almejavam a geração de conteúdos que contribuíssem tanto para a difusão da importância desse idioma no mundo contemporâneo quanto para o processo de formação de professores de Espanhol como Língua Estrangeira (ELE).

Nesse caminho, buscou-se criar um canal de diálogo entre a comunidade acadêmica da UNIR - professores, alunos e técnicos - e outros convidados externos, brasileiros ou estrangeiros. Cada live teve duração de mais ou menos duas horas. Os convidados, mediadores, dias e horários dos encontros foram divulgados previamente nas redes sociais e páginas institucionais ${ }^{1}$.

1 Páginas institucionais: Departamento de Línguas Estrangeiras http://www.dle.unir.br; Curso de Letras Espanhol http://www.letrasespanhol.unir.br. 
Como constava na proposta inicial, de junho a setembro foi ofertada uma charla ${ }^{2}$ por semana, totalizando quatro ou cinco eventos por mês. Entretanto, com o retorno das aulas remotas, o número das lives foi reduzido, passando para oferta de duas charlas em outubro e uma em novembro.

Em vista de explicitar alguns momentos do projeto, o objetivo deste texto é apresentar uma análise sobre a importância de eventos que ofereçam temas direcionados aos Estudos da Tradução em suas mais diversas essências. Esses eventos são importantes porque acabam expondo os diferentes caminhos a que a tradução pode levar-chegar. Desse modo, vale ressaltar que as lives comentadas e apresentadas aqui estiveram sob a responsabilidade e a mediação da própria autora do texto. Houve outras charlas direcionadas à tradução, mas por terem sido mediadas por outros colegas não farão parte do escopo deste trabalho. Dessa maneira, para a realização das mediações e para a composição desta publicação, a fundamentação teórica foi pautada, principalmente, em Nord (2016), Bassnett (2014) e Hurtado Albir (2007).

A fim de elucidar melhor a organização deste escrito, primeiro será realizada uma breve apresentação das charlas que ocorreram, uma no mês de setembro e outra no mês de outubro. A primeira delas foi intitulada La traducción como estrategia pedagógica para clases de lenguas extranjeras/adicionales $\mathrm{e}$ a segunda Un panorama sobre los Estudios de Traducción: Brasil y Colombia. Em seguida, será apresentado o conteúdo explanado pelos palestrantes responsáveis e como os Estudos da Tradução podem ser direcionados a partir de diferentes olhares e perspectivas segundo as teorias, os propósitos e as abordagens. Por fim, será descrito um breve panorama em relação aos retornos recebidos dos ouvintes pontuados também nas considerações finais.

\section{As Charlas direcionadas aos Estudos da Tradução}

A primeira live, intitulada La traducción como estrategia pedagógica para clases de lenguas extranjeras/adicionales, começou a ser pensada e planejada no mês de julho, quando a mediadora entrou em contato com as professoras pa-

2 Para este texto serão usados os termos charla(s), live(s), encontro(s) e palestra(s) como sinônimos. 
lestrantes. Inicialmente, as três professoras líderes do grupo de pesquisa $\mathrm{CNPq}$ $\mathrm{TraCEF}^{3}$ foram convidadas, porém uma delas preferiu não assumir a responsabilidade por motivos pessoais. O propósito de ter as três professoras como palestrantes era buscar apresentar aos ouvintes como elas, egressas da Universidade Federal de Santa Catarina (UFSC) e do Programa de Pós Graduação em Estudos da Tradução (PGET-UFSC), estavam difundindo os conhecimentos aprendidos sobre tradução nas instituições onde trabalham.

A primeira apresentação ocorreu no dia quinze de setembro e, mesmo com a ausência da professora Noemi (UFJF), as docentes Camila Teixeira (UFSC) e Maria Laiño (UFFS), gentilmente, se dispuseram a realizar a apresentação de forma conjunta sobre algumas perspectivas acerca da tradução pedagógica e/ou didática da tradução 4 .

Dessa maneira, as professoras Maria Laiño (UFFS) e Camila Teixeira (UFSC) iniciaram as falas expondo uma breve introdução sobre os Estudos da Tradução e, em seguida, abordaram alguns aspectos tradutórios inseridos no processo de tradução. $\mathrm{O}$ segundo momento das falas foi direcionado às teorias da tradução pedagógica e, ao finalizarem a apresentação, sugeriram algumas atividades desenvolvidas com os alunos.

A segunda live foi oferecida no mês de outubro ${ }^{5}$ e os convidados foram os professores doutores Martha Lucía Pulido Correa, professora da Universidad de Antioquia, Colômbia, e Walter Carlos Costa, professor aposentado da UFSC e colaborador da Universidade Federal do Ceará, Brasil (POET-UFC). A professora Martha esteve, recentemente, como professora visitante na UFSC por três anos e é reconhecida por ser uma das criadoras da Revista Mutatis $\mathrm{Mu}$ tandis Revista Latinoamericana de Traducción ${ }^{6}$, além de ter vasta experiência e um extenso currículo em Estudos da tradução e história da Tradução. O profes-

3 TraCEF - Tradução, Cognição, Ensino e Funcionalismo - Líderes do grupo: Professoras Doutoras Camila Teixeira Saldanha (UFSC), Maria José Laiño (UFFS) e Noemi Teles de Melo (UFJF). Mais informações disponíveis em http://dgp.cnpq.br/dgp/espelhogrupo/380370.

4 Mais informações sobre a charla no site do evento: https://www.even3.com.br/pcsfseptiembre2020.

5 Mais informações sobre a charla no site do evento: https://www.even3.com.br/pcsfoutubro2020.

6 Mais informações sobre a revista https://revistas.udea.edu.co/index.php/mutatismutandis/index. 
sor Walter Carlos Costa é reconhecido por ser um dos precursores na criação da PGET - UFSC e por colaborar na implementação de tantos outros programas de pós-graduações voltados para a área de Tradução. A segunda charla, conforme mencionado anteriormente, intitulada Un panorama sobre los Estudios de Traducción: Brasil y Colombia ${ }^{7}$, foi realizada de maneira diferente da primeira, uma vez que o formato utilizado não foi o de palestra, mas de diálogo. Essa diversificação das mediações ocorreu em todas as charlas do projeto, porque os mediadores ajustavam os eventos para que os convidados pudessem expor os conteúdos de maneira agradável e para que se sentissem confortáveis. Por isso, para essa segunda live, a mediadora realizou ao todo três perguntas para os convidados, conforme cada pergunta era realizada os professores respondiam a partir de suas realidades e vivências profissionais. O professor Walter apresentou algumas informações e gráficos mostrando a realidade brasileira, enquanto a professora Martha explanou oralmente seus conhecimentos baseada em algumas anotações prévias, complementando a fala quando necessário.

Os dois eventos supracitados foram mediados de maneiras distintas de acordo com as solicitações dos convidados. A mediadora, por sua vez, buscou atender as necessidades e expectativas dos palestrantes para que pudessem explanar os conteúdos e debater questões dos ouvintes. Além disso, a escolha dos temas propostos se deu a partir dos currículos e das experiências profissionais de cada um dos convidados.

\section{Percursos, trajetórias, abordagens e possíveis caminhos dos Estudos da Tradução narrados no Charlas sin Fronteras.}

O objetivo da live intitulada "A tradução como estratégia pedagógica para aulas de línguas estrangeiras/adicionais" foi mostrar os possíveis caminhos da tradução em sala de aula. Dessa maneira, a apresentação das professoras foi iniciada comparando a tradução a uma ponte, ao afirmarem que a tradução serve como uma ponte para ligar uma língua à outra e uma cultura à outra. A analogia feita é a de que a tradução conecta um texto de partida a um texto de chegada.

7 Esta charla está disponível no canal do YouTube: https://www.youtube.com/watch?v=Ji80Q1EelOk\&list=PLU46SV1Gt5Lea0vwi31o-bfiJgL7QIGIC 
Os slides iniciais estavam compostos por imagens de diversas pontes, elucidando que as diferentes pontes representariam os distintos tipos e estilos de tradução. Além disso, foi mencionado que uma ponte mal estruturada pode cair a qualquer momento, como é o caso de uma tradução realizada a partir de um tradutor automático. Uma tradução que apresenta problemas de comunicação não chega, por inteiro, ao receptor final do texto. As autoras também comentaram que existem pontes bem estruturadas, bem firmes e que, apesar do peso excessivo de diversos veículos, estas pontes não cedem. Esse momento faz alusão a uma tradução bem estruturada na qual o tradutor se preocupa com todos os elementos presentes no processo tradutório e no produto final. Para exemplificar esse processo, trazemos as palavras de Bassnett (2014) quando afirma que a tradução está longe de ser um processo de simples transferência linguística por se tratar uma atividade complexa de intensa negociação entre línguas e culturas. Sendo assim, enganam-se aqueles que pensam que a tradução é um ato simples, rápido e pode ser resolvida de maneira mecânica.

Nesse sentido, pode-se afirmar que nenhuma língua compartilha a mesma estrutura de outra e, por esse motivo, fazem-se necessários ajustes para tentar preencher os espaços quando não existe um correspondente linguístico-cultural na língua de chegada, isto é, quando não há um equivalente de palavras ou ideias expressada na língua de partida (Bassnett, 2014). O papel do tradutor, nesses casos, é enxergar a polissemia das palavras, dos sentidos entre uma mesma cultura ou entre diferentes culturas, conciliar essas diferenças linguístico-culturais e fazer escolhas, muitas vezes difíceis, a fim de buscar soluções para resolver essas diferentes visões de mundo.

Dando sequência na apresentação, as professoras apresentaram algumas definições para três elementos que, de certa maneira, geraram polêmica entre tradutores e teorias, são elas: equivalência, fidelidade e competência tradutória.

\subsection{Equivalência}

Para a problemática da equivalência, segundo as professoras, é necessário que o tradutor reflita sobre esse fator, pois as línguas e as culturas são viven- 
ciadas de diferentes maneiras. Além disso, a equivalência deve ser considerada no ato tradutório para que a tradução seja adequada ao público receptor.

As palestrantes apontaram o conceito de equivalência para os teóricos alemães Hans Vermeer e Katherine Reiss (1996). Para estes autores, “a função comunicativa de um texto pode indicar quais são os elementos textuais que irão prevalecer e que determinarão a hierarquia de equivalência requerida no processo de tradução", que serão marcadas pela teoria de equivalência, ou seja, a "dita equivalência inclui (com a situação) todos os fenômenos culturais (não somente verbais) dando a eles uma mesma importância” (REISS \& VERMEER, 1996, p. 26). Vemos que, para essa teoria, a equivalência textual se dá quando o texto fonte e o texto meta "cumprem a mesma função comunicativa em ambas as culturas" (REISS \& VERMEER, 1996, p. 126). Esta definição está ancorada no objetivo da tradução, isto é, o valor do texto traduzido se acentua e, por isso, há uma adequação aos leitores finais. Sendo assim, o processo de tradução deve ser pensado a partir do objetivo de tradução, em direção à adequação dessa tradução ao seu leitor final.

São diversas as concepções e, sendo assim, a teoria adotada pelo tradutor é que vai definir sob qual perspectiva o critério de equivalência será considerada.

\subsection{Fidelidade}

A questão da fidelidade ao texto gera polêmica e é um tema que aparece em debates sobre os valores que circundam texto fonte (TF) e o texto traduzido (TT). Em relação à fidelidade, existe um mau entendimento em relação ao fato do tradutor ser ou não fiel ao texto fonte, ou seja, há uma dualidade de fidelidade: ser literal ou livre. Para essa questão de fidelidade na tradução, diversos teóricos esboçam conceitos como "estrangeirização" e "domesticação". A autora Bassnett (2014) aponta que, no campo da tradução, sempre haverá discussões acerca da construção da identidade nacional como forma de entender ou construir a imagem de outras culturas. Para Susan (2014), essas duas estratégias tem a intenção de fazer com que o leitor compreenda o texto e enriqueça seu conhecimento diante de elementos sociais, culturais e econômicos 
distintos do seu. Em outras palavras, são os métodos de tradução que priorizam o TF e suas marcas linguísticas e culturais (estrangeirização) ou levam o autor ao leitor. Sendo assim, as escolhas tradutórias se aproximam do leitor final, como se o texto estivesse sido escrito na língua de chegada, eliminando marcas linguísticas e culturais do TF (domesticação).

A concepção funcionalista busca um equilíbrio entre ser fiel e livre, tornando a questão de fidelidade uma relação intercultural entre o TF e o TT. Assim, Nord (1991, p. 22) ressalta que é possível "tornar o texto muito fiel, ao reproduzir precisamente todas as características do TF, ou muito livre, devido a adaptações ou paráfrases inaceitáveis para contornar obstáculos provenientes de diferenças culturais”. Essa relação intercultural se faz necessária para que o tradutor consiga manter a intenção do TF e, em outros momentos, aproximar o leitor final ao autor do texto.

\subsection{Competência Tradutória}

Em relação às competências tradutórias, a referência teórica para esse assunto é a professora Amparo Hurtado Albir, líder do grupo de pesquisa PACTE $^{8}$. Segundo Hurtado Albir (2007), qualquer falante bilíngue apresenta competência comunicativa entre as línguas que compreende, porém não quer dizer que este sujeito apresente competência tradutória. Nesse aspecto, as competências tradutórias a serem desenvolvidas e aprendidas pelos tradutores são:

- Competência Linguística na L1 e na L2: dominar aspectos formais e semânticos de vocabulário e de gramatica;

- Competência Cultural: estudos relativos à cultura de partida e cultura de chegada;

- Competência Factual: conhecimentos em áreas especializadas relacionadas à política, à economia, ao direito, ao comércio, etc.; e

- Competência Técnica: direcionada à documentação e à pesquisa como uso de dicionários, de métodos bibliográficos, de armazenamento de informações, etc.

8 Mais informações sobre o grupo de pesquisa da professora Amparo Hurtado Albir em: https://grupsderecerca.uab.cat/pacte/es 
No tocante à teoria apresentada pelas convidadas, a professora Camila Teixeira (UFSC) apresentou conceitos necessários para entender e compreender a tradução funcionalista, os caminhos e as concepções acerca dessa área. Ela iniciou a fala expondo conceitos sobre língua pontuando alguns teóricos como Marcuschi, Antunes ao mesmo tempo em que trouxe conceitos sobre texto a partir da visão de Koch, Costa e Salces. A docente apresentou, ainda, conceitos relacionados aos gêneros do discurso e aos gêneros textuais.

Após essa exposição teórica sobre língua, texto e gêneros discursivos e textuais, as palestrantes abordaram, brevemente, o surgimento dos primeiros momentos da tradução em sala de aula, mostrando quando e onde tudo começou. Segundo a explanação das professoras, durante os séculos 17 e 19, o ensino do Latim nas escolas europeias era voltado para regras gramaticais e os estudos eram direcionados às declinações e conjugações. A tradução era realizada de maneira descontextualizada, ou seja, não havia um propósito por se tratar de traduções de frases soltas com apoio em dicionários. Nessa época, acreditava-se que o uso dos dicionários era suficiente para a demanda tradutória. $\mathrm{O}$ foco do ensino era a língua materna do aluno e a produção escrita. A repetição e a tradução mecanizada eram o cerne do método gramática-tradução (MGT). Em contrapartida, surgiram os métodos direto e áudio-lingual, voltados para a língua estrangeira. Para ambos os métodos, a língua materna era abolida da sala de aula, pois o enfoque recaía sobre a língua oral, prevalecendo, então, a proibição da língua materna em sala de aula e estabelecendo a repetição como prática dominante nesses ambientes de aprendizagem. A tradução no método áudio-lingual era utilizada em níveis avançados da língua e como exercícios literários.

Eis que surge a Abordagem Comunicativa (AC), ou método comunicativo, enfatizando o uso da linguagem a fim de estabelecer uma comunicação efetiva entre os interlocutores e de aproximá-los ao máximo por meio de uma comunicação "real/autêntica". Neste caso, o contexto passa a ter um papel importante para a comunicação, pois a partir dele as escolhas linguísticas e as situações de comunicação eram desenvolvidas.

Como consequência da AC, a tradução e a Língua Materna voltaram, aos poucos, para o contexto sala de aula de maneira restrita, sem muitas refle- 
xões e apresentando pouca produtividade. Pode-se perceber, nesse contexto detalhado até o momento, a importância de como e quando usar a tradução de maneira contextualizada. Dessa maneira, o aluno/tradutor pode refletir suas escolhas, se familiarizar com os conceitos e enxergar a tradução como uma atividade de comunicação, de ação real.

$\mathrm{Na}$ contramão das visões formalistas de língua que dividem o texto em estruturas linguísticas (semântica, sintaxe, morfologia, etc.), as professoras Maria Laiño (UFFS) e Camila Teixeira (UFSC) ressaltam a importância de conceber o texto dentro de um contexto para que haja uma interação comunicativa. Sendo assim, o texto deve apresentar objetivos claros e ser direcionado à ação comunicativa, ou seja, a um propósito de comunicação. Além disso, os elementos intratextuais e extratextuais devem ser pensados na hora da produção textual e da tradução.

Uma das estratégias para a produção textual em sala de aula, apresentadas pelas convidadas, é o uso da Sequência Didática (SD) proposta pelos autores Dolz, Noverraz e Schneuwly (2004, p. 83). Essa concepção é direcionada para a produção de textos, orais e escritos, para o ensino de línguas e para outras atividades voltadas à comunicação. Para os autores, a SD possui uma estrutura base que consiste em: apresentação da situação; produção inicial; módulos 1,2, n (quantos forem necessários) e a produção final.

Além do uso da SD para a produção textual e para o processo de tradução, a professora Camila Teixeira (UFSC) apresentou o conceito de retextualização para o trabalho com a tradução em sala de aula. Nesse sentido, se compreende a tradução também como retextualização de outro texto ou de um fato para outro. A retextualização contribui para que o tradutor reflita a respeito dos elementos do texto como: a audiência de partida e de chegada, o propósito do texto de partida e de chegada, o contexto de partida e de chegada, etc.

Saldanha (2018) apresenta como retextualização a ampliação textual, a escrita de um novo texto partindo de outros textos. Nesse processo, quatro habilidades estão inseridas e podem ser trabalhadas, são elas: fala-escrita, fala-fala, escrita-escrita e a escrita-fala. Dessa maneira, a retextualização pode ser realizada entre o mesmo idioma ou entre diferentes idiomas (tradução intralingual e in- 
terlingual); não necessariamente envolve a tradução de um gênero textual para outro, podendo ser a retextualização de um gênero para o mesmo gênero textual (ex: folheto turístico escrito para folheto turístico escrito); e, por fim, devem ser respeitados os seguintes aspectos: objetivo, propósito, intenção da retextualização-tradução, além do tempo-espaço no qual o novo texto estará inserido.

Finalizando a primeira charla sobre o conceito de tradução pedagógica, as professoras Maria Laiño (UFFS) e Camila Teixeira (UFSC) exemplificaram algumas atividades desenvolvidas com os alunos, explicando como foi realizado o processo das SDs e os elementos presentes nas reflexões. De maneira bastante pedagógica, as docentes associaram a teoria evidenciada a alguns exercícios que serviram de prática em sala de aula. Ao final, os ouvintes da charla puderam tirar suas dúvidas em relação aos conceitos e às atividades do uso da tradução em sala de aula. Alguns alunos das referidas professoras assistiram ao evento e também colaboraram frisando a importância das atividades realizadas para a formação de cada um.

Elucidando a tradução e os possíveis caminhos que os Estudos da Tradução podem oferecer, realizou-se a segunda live mediada pela autora do presente texto. O propósito desta charla foi apresentar um panorama sobre os Estudos da Tradução no Brasil e na Colômbia. Em razão dos pedidos feitos pelos convidados, esse evento teve um caráter mais informal, mais dinâmico e mais dialogado.

A mediadora propôs aos convidados três perguntas que nortearam a live. A primeira pergunta direcionada aos convidados foi: "Quais são os principais momentos dos Estudos da Tradução na Colômbia e no Brasil?”. A professora Martha Lucía Pulido Correa, professora da Universidad de Antioquia, relatou que, na Colômbia, não se falava de/sobre tradução até 1995, quando houve a criação da "pré-graduação". O programa de Estudos da Tradução era um programa de 05 anos no qual se ensinava inglês e francês nos dois primeiros anos, já que os alunos ingressantes não tinham fluência e tampouco competências nestas línguas. Os três anos seguintes do curso eram direcionados às disciplinas de tradução e também para aperfeiçoar ainda mais o conhecimento das línguas inglesa e francesa. A palestrante acrescentou que, no ano de 1994, foi criado, na Colômbia, o primeiro curso de especialização em Tradução com 
ênfase em terminologia. A professora Martha Lucía Pulido Correa frisa que, na Colômbia, até os anos 90, não havia uma preocupação em formação de tradutores, porque bastava que os profissionais fossem proficientes na língua, fizessem concurso e se tornassem, então, juramentados. A maioria desses tradutores se concentrava em Bogotá, capital do país e a partir dos anos 90 é que começaram a ser criadas especializações em Medellín e em Río Negro, cidades colombianas que, hoje, são referências em relação aos Estudos da Tradução, e que, inclusive, oferecem Mestrado em Tradução. A professora destacou, também, que, em um primeiro momento, a preocupação acerca da tradução era apenas em certificar os tradutores para que pudessem atuar. Com a crescente necessidade de traduções, foram criadas especializações e pós-graduações e, por fim, pesquisas direcionadas à tradução.

Finalizada a fala da professora Martha, o professor Walter Carlos Costa, professor aposentado da UFSC, iniciou a apresentação de um breve panorama dos Estudos de Tradução no Brasil. Ele destacou que, no Brasil, há uma distinção grande entre a graduação e a pós-graduação em Estudos da Tradução. De acordo com este professor, antigamente, a graduação tinha mais prestígio, porém com os atuais auxílios, bolsas, exigências e recursos da CAPES, as pós-graduações passaram a ganhar mais destaque e importância em âmbito nacional.

O curso de graduação mais antigo de tradução no Brasil é o da UNESP, de São José do Rio Preto, seguido pelo curso da UFRGS e o da PUC-RIO. O referido professor também mencionou a UnB de Brasília, além de outras instituições que não funcionam mais, como a Unibero, entre outras. Os Estudos da Tradução se destacaram a partir das pós-graduações. Destacando-se entre os demais países da América Latina, o Brasil é considerado um dos países mais respeitáveis no âmbito de tradução, porque houve uma preocupação em institucionalizar e reconhecer os Estudos da Tradução não apenas como uma disciplina, mas como um curso e uma carreira.

Antes de passar para a segunda pergunta, a professora Martha Lucía Pulido Correa pediu a palavra e complementou as informações que ela havia dado anteriormente, sobre a existência de cursos de especializações e mestra- 
dos em estudos da tradução com o enfoque na formação de tradutores, ou seja, direcionados à didática de tradução existentes na Colômbia.

Respondida a primeira pergunta, a segunda pergunta foi: "Vocês acreditam que a pandemia afetou de alguma maneira a trajetória dos Estudos da Tradução?”. A professora Martha Lucía disse que sim e, em tempos de pandemia, teve que deixar as pesquisas e outras atividades que realizava para atender os alunos e dar mais atenção a eles. Além disso, ela ressaltou que têm participado de diversos eventos e de outras ações que acabam sendo demandas da universidade na qual trabalha e de outras instituições onde ela atua como convidada. A professora destaca essas ações como elementos positivos da pandemia, visto que são relações que acabam aproximando pessoas, culturas, temas e países. Finalizando a fala, em relação ao ensino e formação de tradutores, Martha Lucía pontuou que não houve prejuízo, porque quando declararam pandemia na Colômbia as universidades e colégios se mobilizaram rapidamente, seguiram imediatamente com as aulas, oficinas e seminários online.

Ainda respondendo a segunda pergunta, o professor Walter Carlos Costa pontuou que, por existir uma diferenciação em relação ao financiamento que a graduação e a pós-graduação recebem, no Brasil, a pós-graduação, em especial a POET-UFC e a PGET-UFSC, retomou os estudos o mais rápido possível em virtude de não prejudicar o andamento das pesquisas e tampouco os pesquisadores-orientandos. Os professores coordenadores dos programas de pós-graduação fizeram um levantamento com os estudantes e não houve resistência por parte dos alunos em voltar às atividades de maneira remota. $\mathrm{O}$ professor Walter destacou, ainda, que houve uma resistência maior dos professores do que dos estudantes. Diferentemente da Colômbia, no Brasil houve uma demora maior para que as aulas fossem retomadas de maneira online. Ele percebeu que a graduação sofreu muito mais impacto do que a pós-graduação por causa da imposição de regras da CAPES, principal fomentador de pesquisas no Brasil. O professor destacou também que o retorno das aulas dele sofreu modificações em relação aos planos do presencial. Neste contexto, ele sentiu a necessidade de realizar convites a outros professores-pesquisadores e dinami- 
zou as aulas para que os alunos pudessem ter esses momentos sobre tradução com pesquisadores de diferentes campos da Tradução.

Os dois professores convidados concordaram que a pandemia serviu como uma oportunidade de rompimento de barreiras educacionais, emocionais e de aprendizagem. Sobre esse aspecto, a professora Martha Lucía complementou a discussão evidenciando que a pandemia proporcionou a todos estar em diversos lugares ao mesmo tempo. Além disso, esse período fez com que ela também repensasse as aulas e se colocasse no lugar dos alunos, passando a entende-los um pouco mais, frente a essa inusitada situação.

Passando à terceira pergunta, a saber: "Como vocês projetam os ETs futuramente, em relação a incentivos, pessoas capacitadas e formação de tradutores?”. Os convidados responderam o seguinte: cada vez mais haverá tradutores especializados não apenas em tradução literária, mas também em outras áreas. A tradução literária, segundo a professora Martha Lucía, foi a pioneira em relação aos ETs, porém existem outros campos de tradução que estão crescendo e se fortalecendo cada vez mais. Um dos campos que tem sido de suma importância, em tempos de pandemia, é a tradução médica, que tem sido essencial para entender o que está acontecendo no mundo atualmente.

Sobre as pesquisas em Estudos da Tradução, o professor Walter Carlos Costa destacou que a bibliografia é uma das mais ricas atualmente. Segundo o que o professor relatou, no Brasil, existem muitas publicações e pesquisas voltadas para os ETs. Ele também mostrou alguns dados obtidos e publicados na dissertação de mestrado de Fernanda Christmann ${ }^{9}$ na qual ela divulga um mapeamento sobre o perfil e o destino profissional dos egressos de doutorado da PGET-UFSC entre os anos de 2010 e 2017.

Para encerrar a fala sobre a terceira pergunta, os professores comentaram sobre a quantidade de publicações que foram e são realizadas em ETs, entre teses, dissertações, livros, revistas acadêmicas e ANAIS de eventos, todos disponíveis na internet e de acesso livre aos interessados. Além disso, reforça-

9 Dissertação submetida ao Programa de Pós-graduação em Estudos da Tradução da Universidade Federal de Santa Catarina. Disponível em https://repositorio.ufsc.br/bitstream/hand1e/123456789/205673/PGET0402-D.pdf?sequence=-1 Acesso em 01/12/2020. 
ram que o campo dos ETs está crescendo e, cada vez mais, aparecem publicações sobre diversos temas em Tradução. Martha Lucía e Walter Carlos Costa mencionaram também alguns grupos de pesquisa responsáveis por eventos e pesquisas direcionadas aos ETs na Colômbia e no Brasil.

\section{Panorama sobre impressões e resultados dos ouvintes}

Ao final de cada charla foram disponibilizados, nos chats, formulários de presença contendo perguntas de satisfação em relação aos eventos assistidos. Havia também questões que possibilitavam obter informações mais pontuais como região, cidade, país, nível de instrução, a instituição de formação, entre outros.

Ao total, foram recebidas 125 respostas na primeira live e 116 respostas na segunda. Os brasileiros estavam em maioria entre os assistentes, porém estiveram presentes colombianos, espanhóis, chilenos e mexicanos nesses dois encontros. Desses assistentes, a maior parte eram estudantes de graduação e de pós-graduação, e em número menor os docentes.

Mais de 90\% dos respondentes sinalizaram a opção "excelente" para o grau de satisfação com os dois eventos. Em relação aos comentários recebidos, o retorno foi bastante positivo em relação à organização dos eventos, em relação aos temas oferecidos, aos professores convidados e aos conhecimentos culturais compartilhados.

Com esses resultados, pode-se constatar que falar de e sobre Tradução é necessário, primeiramente, porque desmitificou os campos, os caminhos e as pesquisas realizadas hoje em dia sobre os ETs, ou seja, cada vez mais percebe-se a importância de valorizar o trabalho e o papel do tradutor bem como os cursos direcionados aos ETs.

A partir das falas dos convidados, foi possível oferecer um panorama de instituições brasileiras e estrangeiras que oferecem cursos de graduação, especialização, mestrado, doutorado e pós-doutorado em ETs. Além disso, foi possível perceber que o ensino da tradução não precisa e não deve ser de maneira mecanizada, estandardizada. $\mathrm{O}$ fazer tradutório está presente em nosso dia-dia e o docente precisa ter consciência de que, para se ter tradução, é pre- 
ciso considerar diversos elementos presentes nesse processo. Partilhando esse viés, Nord (2016) compreende a tradução como uma ação comunicativa real estabelecida em um ambiente autêntico, ou seja, todo texto produzido, seja ele oral ou escrito, de partida ou de chegada, é carregado de um propósito à medida que faça correspondência para o leitor meta na sua recepção. Segundo a mesma autora, todo propósito de um texto é voltado para um receptor final estabelecido por um contexto específico:

Se considerarmos o texto uma ação comunicativa, é evidente que na análise textual as dimensões da situação comunicativa, bem como os participantes no ato comunicativo, devem ser os fatores primordiais. Em uma análise orientada para a tradução, teremos primeiro que analisar esses elementos e a sua função na situação do TF e, em seguida, compará-los aos fatores correspondentes na situação (prevista) do TA, uma vez que o texto alvo também, como o texto fonte, será incorporado em uma interação comunicativa que determina a sua recepção (Nord, 2016, p.39).

Visto dessa maneira, percebe-se a tradução como um processo além de uma transcodificação linguística, já que o texto de partida tem como propósito uma ação comunicativa com receptores do texto fonte e que o texto de chegada também terá uma função de ação comunicativa com seus receptores.

Dada essa teoria e a importância de reconhecer o papel do tradutor, tivemos a presença de 05 tradutores. Na primeira charla estavam presentes duas palestrantes e uma mediadora, enquanto na segunda live outros dois convidados e a mesma mediadora participaram.

Os caminhos que os ETs podem levar são diversos, requer muito estudo, muita pesquisa, tempo, paciência e persistência do tradutor. Perceber o papel do tradutor é perceber também o papel fundamental do professor. Para encerrar esta parte do trabalho, serão expostos alguns comentários recebidos que traduzem os dois eventos. 


\section{Quadro ilustrativo com comentários dos ouvintes.}

Excelente trabalho realizado, todas as falas, observações, dicas, informações sobre o tema de abordagem. Os professores de alta qualificação.... Supriu todas minhas dúvidas...

Gostei muito como fomos sendo guiados durante a live, nos temas tratados, aprendi muito, obrigada.

Agradeço a oportunidade em participar do evento, está sendo muito produtivo e inspirador para minhas práticas em sala de aula.

Excelente exposição, foi minha primeira vez tendo contato com teoria da tradução e não senti dificuldade de compreensão.

Foi uma live com um padrão de excelência deixou muito bem claro sobre a tradução de um texto, o gênero textual e retextualização, dras muito boa para transmitir o conhecimento sobre o assunto.

O encontro (charla) de hoje foi excelente! Trouxe muitas reflexões importantes na área de tradução. Muito interessantes as propostas de aplicação/produção de material didático apresentadas.

A live trouxe uma excelente temática e proporcionou muito conhecimento e reflexões acerca do uso da tradução em sala de aula. Apesar de não ter conseguido assistir desde o iniciozinho foi de grande valia ter participado. Só tenho a agradecer, muito obrigada!

Fator positivo que a pandemia nos trouxe. Os encontros virtuais. Excelente trabalho. Parabéns aos coordenadores deste excelente evento.

Assisti as primeiras palestras sobre tradução e minha experiência foi ótima. Agora graças a esta apresentação consegui aumentar meus conhecimentos e fico realmente grato pela oportunidade e pelo conhecimento compartilhado. As professoras são incríveis e simplesmente amei a palestra. Muito obrigado.

O assunto tratado e de suma importância, pois hoje vemos vários métodos que são aplicados nas traduções independente de qual língua seja, e de acordo com a evolução do século XXI é importante trabalharmos esses assuntos no âmbito literário.

A live foi de caráter muito proveitoso, pois despertou o interesse em muitos outros estudantes/ pesquisadores na área de estudos da tradução, tema muito bem explanado pelos palestrantes.

Excelente discussão, principalmente nesse momento de pandemia no qual esses debates nos aproximam!!!

Muito bem organizado, excelentes pontuações e agregou muito em meu conhecimento. Muito grata por essa live!

Grata aos professores e a todos os envolvidos pela oportunidade de obter conhecimentos tão significativos! Excelente palestra!

Charla Sin Frontera é um projeto maravilhoso, que nos oferece a oportunidade de conhecer pessoas com uma bagagem de experiência muito grande e a partir daí nos dá a oportunidade de aprender, de conhecer. Quero agradecer a todos e aos professores que se dispõe a nos dar um pouco do seu tempo para nos presentear com tanto conhecimento, curiosidades e incentivo. Estou amando participar desses mini-cursos.

Fonte: Formulário de presença das Charlas 15 e 19. 
Um aspecto importante a ser destacado é que o recorte dos comentários foi aleatório e, para nenhuma das charlas, houve comentários negativos ou que sugerissem melhoras. Houve pedidos solicitando mais eventos que abordassem os ETs direcionados para outras áreas mais específicas.

\section{Considerações Finais}

Foi possível perceber que existe um público buscando por eventos que sejam, em primeiro lugar, sobre tradução, em segundo, gratuitos, e, terceiro, que sejam realizados de maneira online. Esses dois últimos fatores mostraram que a pandemia aproximou pessoas de diversos lugares do Brasil e de muitos outros países hispano-falantes, o que seria impossível caso os eventos fossem presenciais.

Por ser a tradução o campo de atuação e de pesquisa da mediadora, o assunto a ser tratado para este trabalho não poderia ser outro. A mediadora arriscou-se oferecer uma live sobre literatura, trouxe uma escritora guatemalteca e, nessa live, puderam debater sobre literatura, política e cultura da Guatemala. Também ofereceu um evento direcionado à lexicografia, outro campo e assunto de interesse de investigação. Nesta live foram abordados temas relacionados aos materiais lexicográficos e um breve panorama da lexicografia. As convidadas dessa vez foram a coorientadora de doutorado da autora deste artigo e a outra palestrante participou como membro da banca avaliadora de doutoramento, duas profissionais com conhecimentos e competência suficientes para oferecer grandes debates e trazer contribuições generosas ao público.

Foram dois os objetivos do projeto Charlas Sin Fronteras. O primeiro deles foi promover conversas sobre diferentes temas relacionados à Língua Espanhola e às culturas dos países hispano-falantes com a pretensão de gerar conteúdos que contribuam tanto para a difusão da importância desse idioma no mundo contemporâneo quanto para o processo de formação de professores de E/LE. O segundo objetivo foi criar um canal de diálogo entre a comunidade acadêmica da UNIR - professores, alunos e técnicos - e outros convidados externos, brasileiros ou estrangeiros. Pode-se concluir que os objetivos do projeto foram atingidos com êxito em todas as lives ofertadas. 
No início, o projeto começou timidamente com a presença de 40 a 60 pessoas e logo o número de inscritos para ouvintes aumentou, superando 150 vagas. Inclusive, em uma das conversas foram extrapoladas as 250 vagas ofertadas, o que fez com que os organizadores criassem um canal no YouTube para transmitir as charlas do projeto ao vivo.

Por fim, ressalta-se que falar de tradução e sobre tradução é falar de uma atividade complexa. A tradução é um ato, é um processo que vai além de transportar uma palavra ou uma língua para outra. Para ter-se tradução é preciso desenvolver conhecimentos, competências tradutórias. Nessa perspectiva, a tradução é percebida em vários âmbitos e níveis, pode ser uma tradução dentro de uma mesma língua (tradução intralingual), assim como pode ser entre línguas diferentes (tradução interlingual) ou até mesmo uma tradução de textos não orais para textos orais, de textos traduzidos para gêneros textuais não escritos (tradução intersemiótica) (Steiner, 1980).

Afinal, o que é tradução? Em poucas palavras, define-se a tradução como um ato de compreensão, interpretação, negociação. Todos nós traduzimos o tempo todo, desde o momento em que nascemos. A tradução é uma atividade milenar e sempre houve a necessidade de usar a tradução para dar-se comunicação.

\section{Referências}

BASSNETT, Susan. Translation, The New Critical Idiom, Routledge, Abingdon. Oxon- New York, 2014.

DOLZ, Joaquim; NOVERRAZ, Michele; SCHNEUWLY, Bernard. Sequências didáticas para o oral e a escrita: Apresentação de um procedimento. In: Dolz, Joaquim; Schneuwly, Bernard (orgs). Gêneros orais e escritos na escola. Tradução de Roxane Rojo e Glaís Sales Cordeiro (p. 21-39). Campinas: Mercado de Letras, 2004.

HURTADO ALBIR, Amparo. Enseñar a traducir. Metodología en la formación de traductores e intérpretes. España: Edelsa, 2007. 
NORD, Christiane. Text Analysis in translation. Amsterdam; Atlanta: Rodopi, 1991.

REISS, Katharina; VERMEER, Hans. Fundamentos para una teoría funcional de la traducción. Madrid, Akal, 1996.

SALDANHA, Camila Teixeira. Proposta de sequência didática (SD) como processo tradutório: os movimentos modulares no processo de ensino e aprendizagem de língua estrangeira. Tese (doutorado) - Universidade Federal de Santa Catarina, Centro de Comunicação e Expressão, Programa de Pós-Graduação em Estudos da Tradução, Florianópolis, 2018.

STEINER, George. After Babel. London: Oxford Univ., 1980. 


\section{CAPÍTULO 6. TODOS CONTRA D@NTE, DE LUÍS DILL: LITERATURA INFANTIL NO CONTEXTO DAS NOVAS TECNOLOGIAS}

Liliane Lenz dos Santos

Aroldo José Abreu Pinto

A grandeza de uma literatura, ou de uma obra, depende da sua relativa intemporalidade e universalidade, e estas dependem por sua vez da função total que é capaz de exercer, desligando-se dos fatores que a prendem a um momento determinado e a um determinado lugar.

(Antonio Candido, 2011)

\section{O leitor e a literatura infantil}

A história do leitor está ligada à história do livro, que teve início na Europa, no século XVIII, aproximadamente. Até então os livros eram feitos de maneira artesanal e exigiam um tempo extenso para sua produção, não estando, assim, ao alcance de muitas pessoas. Porém, a partir de determinada época, a impressão de obras escritas passou a ser exercida por hábeis tipógrafos e, posteriormente, foi gerenciada pelo Estado que manipulava, por meio de documentos, permitindo ou não a produção dos livros. Dessa forma, essa atividade tornou-se empresarial, dentro dos moldes capitalistas, dirigida para o lucro.

Sendo o livro a partir de então produzido em maior escala, gerando maiores lucros com menos custo, surgiu também a necessidade de novos consumidores. Segundo Lajolo e Zilberman (2019, p. 24), "para a leitura se expandir a ponto de se transformar em prática social, foi também necessária outra mudança: deu-se uma até então inédita e a partir daí permanente valorização da família”.

O regime absolutista foi sendo substituído pela democracia após as revoluções dos séculos XVIII e XVI, fortalecendo a burguesia e suas ideologias e no projeto burguês, a família era imprescindível, pois constituía ao mesmo tempo a 
unidade e o fragmento. "Unidade porque apresenta laços internos sólidos, sustentados pela ideologia familista, [...]; fragmento, por resultar da desagregação dos grandes grupos a que outrora se integrou" (Lajolo; Zilberman, 2019, p. 25).

É nesse contexto de modelo familiar que o prazer da leitura é estimulado e intensificado, pois se mostrou uma atividade adequada à vida doméstica. Sendo assim, os livros, financiados também pelos burgueses, passou a ter uma linguagem mais facilitada, para ser compreendida por essa nova classe de pessoas e a tratar de assuntos condizentes com o momento, para que a burguesia pudesse se encontrar dentro deles.

Com a burguesia e os livros deu-se a necessidade de ampliação das escolas para formar os filhos dessa nova classe e, diante disso, a necessidade também de professores que trabalhassem com esse público.

No Brasil, a história da escola mistura-se à história da literatura infantil e do livro didático, haja vista a necessidade de se criar obras para o público infantil que estavam sendo direcionadas à instituição escolar, com a vinda da família imperial.

Após a expulsão dos jesuítas pelo Marques de Pombal, o domínio clerical do ensino se findou. A partir de então era a Coroa quem designava quem poderia exercer as funções pedagógicas. Em 15 de outubro de 1827 a educação foi oficializada no Brasil com um Decreto imperial de D. Pedro I, que determinava que todo lugarejo e vilas tivessem suas escolas de primeiras letras, porém essa data só foi oficializada em 1963.

Dessa maneira a imprensa e o livro didático nasceram sob a tutela do Estado, sendo obrigados a sujeitar-se a ele, como se verifica na passagem: "Era uma escola que nasceu precária; como a imprensa, também ela foi fruto de necessidades geradas pela transferência da Corte portuguesa para o Brasil, com as consequentes improvisações. Sem, contudo, a providencial intervenção do acaso" (Lajolo; Zilberman, 2019, p. 171).

Contudo, a escola não teve grandes avanços, emergia dela um quadro negativo, onde predominava o desinteresse, o autoritarismo e despreparo por parte dos professores, os prédios tinham instalações precárias e isso tudo causava a indiferença e desinteresse por parte dos alunos. 
Foram instituídas nesse período as escolas particulares e escolas públicas, financiadas pelo Estado. A remuneração dos professores era muito baixa, tanto nas escolas públicas quanto privadas, independentemente de estar na capital ou nas províncias. Walsh (1985, p. 21) afirma que, nessas, onde a educação era gratuita, porque mantida pelo governo, “o salário de um professor primário geralmente girava em torno de trezentos dólares; os outros recebiam cerca de quinhentos”, não sendo melhor a situação nas províncias”.

Em todos os lugares havia falta de professores, pois as pessoas buscavam por melhores salários, sendo assim somente os de menor capacidade profissional se sujeitavam ao trabalho do ensino. Por conta dos baixos salários, os professores que se dispunham a atuar não tinham condições de fazer cursos para melhorar a sua prática, como também não podiam adquirir novos livros, tendo em vista os preços excessivos que esses livros tinham. Dessa maneira, ensinavam apenas aquilo que aprenderam com seus mestres, utilizando também a mesma metodologia, haja vista a não participação em cursos de capacitação.

Considerando os depoimentos posteriores, o mau estado do ensino brasileiro parece persistir; e os cronistas da vida social brasileira acoplam o mau estado do ensino com a má qualidade e/ou a inexistência de livros escolares. Sob tais condições, a formação de um público leitor se arrasta, inclusa e rarefeita (Lajolo; Zilberman, 2019, p. 194).

Alguns legisladores, como Cunha Barbosa, procuraram resolver o problema do livro didático, defendendo um manual único para ser usado em todo território brasileiro, cabendo ao Estado a aprovação desse livro e a regulamentação das matérias que nele deveriam conter. Porém, a capacitação e melhora dos salários dos professores não foi discutido nesse momento. Fica evidente como o trabalho humano intelectual foi desprezado desde os primórdios.

A discussão desse novo sistema escolar não frutificou e, assim, o ensino foi pulverizado. Diante disso, as escolas particulares aproveitaram o momento para improvisar ambientes e acolher o número de alunos que surgia. Os ambientes eram péssimos e o processo de profissionalização dos professores 
também. Então a educação no Brasil foi iniciada de maneira precária e sem o empenho dos seus então governantes.

\section{A trajetória da literatura infantil no Brasil}

A literatura infantil surgiu com o propósito de educar moralmente as crianças, as histórias eram maniqueístas e buscavam delimitar o bem e o mal, para que os pequenos leitores internalizassem aquilo que deveriam seguir e compreender que o mal lhes levaria a caminhos desastrosos.

Anterior aos anos finais do século XVIII, a circulação das obras literárias era precária e irregular, sendo representada principalmente por edições portuguesas, posteriormente essas edições foram traduzidas para o português nacional. Como afirma Cunha (1987, p. 20), "no Brasil, como não poderia deixar de ser, a literatura infantil tem início com obras pedagógicas e, sobretudo, adaptadas de produções portuguesas, demonstrando a dependência típica das colônias”.

O surgimento dessa vertente da literatura, a literatura infantil, deu-se no mesmo período da abolição da escravatura e do advento da República, sendo necessário formar a imagem do Brasil como a de um país que estava em processo de modernização, ostentando a renovação que o Estado passava nas suas instituições políticas e culturais, que se dava através da importação do café, produto colonial cultivado em modelo capitalista. O Brasil precisava revelar-se como um país evoluído e desenvolvido e, para isso, utilizava-se do meio intelectual, a literatura.

A extinção do trabalho escravo, o crescimento e a diversificação da população urbana, a incorporação progressiva de levas de imigrantes à paisagem da cidade, a complexidade crescente da estrutura administrativa são sinais da nova situação. E são eles que começam a configurar a existência de um virtual público consumidor de livros infantis e escolares (Lajolo; Zilberman, 1988, p. 15).

As obras literárias passaram então a criar e divulgar o conceito de um novo país comprometido com sua modernização.

Nessa época, o homem de letras foi profissionalizado, tornando esse período um tempo rico e complexo, pois os intelectuais brasileiros sofriam grande 
influência dos escritores europeus. A produção nacional começa a surgir, mas ainda conserva uma linha de apropriação e imitação do produto europeu, ainda que com linguagens e representações mais próximas à realidade brasileira.

As temáticas nacionais também começam a surgir na literatura infantil, mas ainda "eram os clássicos infantis europeus que forneciam o material para as adaptações e traduções que precederam a propriamente dita produção brasileira de literatura infantil"(Lajolo; Zilberman, 1988, p. 17), ainda que os textos fossem traduzidos e abrasileirados, aumentando a aceitação junto ao público infantil.

Essa adaptação das obras para o público infantil indicou o movimento de nacionalização e em outros desdobramentos se transformou em obras nacionalistas, difundindo as imagens de grandeza e modernidade do país. Sendo assim, a literatura inculcou no público leitor os projetos nacionalistas, destacando o patriotismo e valorização da pátria.

O novo regime político da República Federativa, que se deu em 1889, buscou a modernização do país, mas depois de trinta anos esse projeto mantinha-se frustrado, pois os grupos tradicionais remanescentes do Império ainda dominavam o Governo, mas na década de 1920 houve um intenso movimento reivindicatório e, a partir de então, a literatura infantil começou a se modernizar e o governo revolucionário facilitou a industrialização nas regiões mais ricas, como o Centro-Sul, e impôs uma reforma no ensino, dando acesso ao público urbano de baixa renda, mas manteve a permanência do mandonismo, em que o pobre deveria continuar a servir o rico.

Após a primeira guerra, os intelectuais brasileiros passaram a aperfeiçoar e apregoar os seus produtos, utilizando-se da tecnologia da época, como o rádio e expansão do cinema, que permitiram uma divulgação mais ampla das suas criações artísticas.

Embora ocorresse uma nova revolução e propagação da literatura infantil e não-infantil através dos novos meios tecnológicos, sua sobrevivência só foi possível por estar atrelada aos interesses do Estado e das instituições que o serviam.

O governo Vargas canalizou a espontaneidade original para os interesses do regime, de modo que o divertimento cultural da população estivesse ligada às temáticas de cunho histórico e pedagógico, como era o caso dos desfi- 
les carnavalescos, da mesma maneira que ocorreu com a literatura infantil, tendo sempre um objetivo pedagogizante, uma lição de moral a ser desenvolvida no estudante, mas de certa forma tendo seu conteúdo divulgado.

Sendo assim, Lajolo e Zilberman (1988, p. 62), destacam que:

O êxito, contudo, não garantiu a autonomia da literatura infantil, que continuava sem legitimação artística: a publicação de obras para crianças não afetava a imagem de seus escritores. $\mathrm{O}$ estímulo parece ter sido outro: o mercado escolar, aparentemente, recompensava o esforço de escrever para os jovens. Porém, como, para circular nas salas de aula, era preciso, além da espontaneidade e imaginação, adequar-se aos cursos vigentes e aos programas curriculares, a fantasia e a criatividade foram indiretamente disciplinadas, favorecendo o Estado que, assim, controlava de alguma maneira a produção de livros destinados à infância.

O livro infantil foi direcionado para a escola, também cedendo aos interesses do estado.

\section{Participação de Monteiro Lobato na história da literatura infantil}

Até o ano de 1945, o espaço privilegiado era o mundo rural e Monteiro Lobato explorou bastante essa visão. Porém, ele se diferenciava dos autores de sua época, pois boa parte de sua produção não se preocupava em apenas moralizar a criança, mas produzia uma obra reflexiva que estimulava os leitores a compreender o mundo a seu redor.

Foi considerado pela crítica como o fundador da literatura infantil brasileira, pois se desprendeu do modelo europeu, colocando em voga personagens do mundo imaginário brasileiro. Em vez dos castelos, apresentou o Sítio do Picapau Amarelo e no lugar de príncipes e princesas apresentou como personagem principal uma boneca de pano que falava pelos cotovelos.

Lobato mostrou o Brasil sob sua própria forma de enxergá-lo. De acordo com Lajolo e Zilberman (1988, p. 67), o Brasil era um país "que se descobre petróleo e se obtém a tão almeja autonomia econômica (v. ‘O abalo de país’) e são seus habitantes que provocam uma revolução mundial destinada a mudar o comportamento da humanidade (v. 'Pôr-do-sol de trombeta' e 'A chave do tamanho')”. 
Ele escreve sobre suas vivências e leituras e procura humanizar o leitor com obras instigantes, dentro do contexto que estava inserido.

\section{O Brasil de mãos dadas com a América do Norte}

Em 1942, o Brasil uniu-se à Inglaterra, França, Estados Unidos e União Soviética e acabou rendido ao assédio econômico e político. Essa nova aliança estreitou as relações entre os Estados Unidos e o Brasil, e nesse período Walt Disney promoveu o papagaio Zé Carioca, como símbolo do povo brasileiro. "Com a anuência final de Getúlio, o capitalismo norte-americano acabou obtendo a concessão definitiva de nosso mercado, que se tornou presa fácil de seus produtos, industrializados e culturais" (Lajolo; Zilberman, 1988, p. 123).

Nesse período o Brasil, que havia deixado de imitar a Europa, passou agora a imitar e propagar a cultura norte-americana, mantendo ainda o modelo educativo anterior dentro da escola.

O espaço representado na literatura a partir de então deixou de ter um sentido simbólico e se converteu em um cenário de ação.

A história infantil mostra a continuidade entre dois tempos - o passado, representado pelos velhos (como o Vovô, do ciclo de Taquara-Poca), e o presente, encarnado pelos jovens - e entre dois espaços, o rural e o urbano, indicados simultaneamente pelas mesmas personagens (Lajolo; Zilberman, 1988, p.127).

A literatura infantil passou por novas alterações, ponderando o antigo com a nova atualidade e apresentou, por meio das narrativas, o desenvolvimento pelo qual estava passando o país, mas sempre demonstrando o comprometimento que existia com a camada dominante da sociedade.

\section{A literatura infantil continua a se modificar}

A evolução na literatura continua acontecendo, pois o país vai se desenvolvendo e ocorrendo grandes mudanças e a literatura representa o seu tempo. A partir dos anos 1960, o Brasil é um país completamente alinhado com o mundo capitalista. 
O setor editorial torna-se mais forte e mais evoluído, tendo em vista que o público estava mais receptivo. Há, com o governo de Juscelino, uma redução e isenção de taxas para a compra de produtos-base na produção do objeto livro e, com isso, dá-se a modernização da indústria e do comércio livreiro.

$\mathrm{O}$ aspecto do livro é renovado em algumas editoras e propagandas incisivas são feitas, inovando a distribuição dos livros, utilizando bancas e farmácias como pontos de venda e isso permite que a literatura infantil e não infantil alcancem um público cada vez maior, o que não significa um público mais intelectualizado, haja vista a necessidade de agradar o leitor, e isso ocorreu também por conta da grande propagação da mídia televisiva.

Assim sendo, multiplicam-se, nos anos 60 e 70, as linguagens e materiais que se fazem presentes na literatura do período: a prosa jornalística de José Louzeiro, a paródia histórica de Márcio de Souza, as alegorias de Antônio Callado, os registros populares e marginais de João Antônio e Plínio Marcos, o humor irreverente de Stanislaw Ponte Preta, a elaboração lírica das letras da MPB e a concisão enxuta da poesia marginal parecem fragmentos de uma literatura que, no geral, reproduz impasses e contradições da realidade brasileira com a qual se articula (Lajolo; Zilberman, 1988, p.175-176).

As novas condições afetam diretamente a produção literária infantil. Como vimos, sua criação foi direcionada à escola desde o início, o que legitima sua existência e o crescimento apontado a partir dos anos de 1960 só fez aprofundar ainda mais essa relação de dependência, servindo muito bem à mediação institucional, que continua vendo a literatura como agente educativo e civilizador.

O fortalecimento do mercado interno e da burguesia ocorre a partir de 1964, com o golpe de Estado e isso faz com que o país assuma um perfil industrializado, refletido também na literatura. O ruralismo visto até 1950 abre espaço total para o universo urbano: "os primeiros livros urbanos dedicaram-se à reprodução verossímil de cenários, condições de vida e valores da classe média brasileira que, a partir do final dos anos 50, iniciava-se em hábitos de consumo" (Lajolo; Zilberman, 1988, p.177). 
Surgem então as obras que apresentam os problemas do cotidiano, a realidade da sociedade, mas não de maneira grotesca, através de uma sensibilidade inteligente, de forma que o pequeno leitor compreendesse que a vida não era feita apenas de belezas, mas que também haveriam momentos de dificuldades e tristezas. Para apresentar essa nova forma de enxergar o mundo, foram produzidas obras esteticamente elaboradas e dentro do realismo social.

\section{A literatura nos moldes atuais}

A literatura, como vimos na trajetória apresentada, acompanha o crescimento e evolução do leitor e atualmente esse leitor se tornou frequentador das redes sociais, local que se sente à vontade para morar e, sendo assim, a literatura mais uma vez se adequa a essa nova realidade.

As autoras Marisa Lajolo e Regina Zilberman apresentaram a trajetória permeada pela literatura infantil, como também apresentam uma nova outra história dessa vertente literária, pois na era atual a tecnologia tomou grande espaço e os leitores têm livre acesso e transitam tranquilamente pelos novos meios tecnológicos. A literatura infantil também se faz presente nesse novo ambiente.

Concebendo a literatura enquanto um sistema por meio do qual obras, autores e públicos interagem a partir de condições sociais que diferentes momentos históricos proporcionam, o novo contexto cultural do país afeta a literatura infantil e juvenil (apenas ela?) desde seu modo de produção até sua forma de circulação, multiplicando as (outras) linguagens com as quais precisa dialogar (Lajolo; Zilberman, 2017, p.14).

A literatura é colocada dentro de um novo universo de possibilidades, que não se restringe mais às folhas coloridas ou não de um livro, abrindo o leque para novas formas, mas ainda distinguindo o público alvo e o gênero a ser apresentado, o que é bastante modificado durante o século XVIII, que dá origem a novos gêneros, aumentando o número de formas narrativas e definindo os livros por critérios e públicos distintos.

A internet permite um novo boom na literatura, pois é constituída por um conglomerado de redes de comunicação, operando de modo inter- 
ligado no que se denomina ciberespaço e isso permite que o leitor tenha acesso a vários livros de formatos e assuntos diferentes, destacando assim novas alternativas de criação, como a construção do hipertexto, que associa o movimento entre o texto e a imagem.

A tecnologia não só influencia a produção e circulação da literatura, mas propõe novos temas, ideias e procedimentos artísticos, sendo o livro Todos contraD@nte, de Luís Dill, um excelente exemplo disso.

\section{Uma leitura de Todos Contra D@nte, de Luís Dill}

Luís Augusto Campello Dill é formado em jornalismo pela PUC/RS, tem pós-graduação em Literatura Brasileira e, como jornalista, já atuou em assessoria de imprensa, rádio, televisão e internet. Atualmente, é Produtor Executivo da Rádio FM Cultura na capital gaúcha, Porto Alegre, onde reside.

Como jornalista, viu muitas situações lamentáveis e uma delas foi a morte de uma garota de 13 anos que foi espancada até a morte por colegas da escola. Ela teria sido derrubada no chão, recebido muitos chutes e socos e, segundo o Instituto Médico Legal do município em que o caso aconteceu, teria morrido asfixiada por aspirar areia e ficar com as veias respiratórias obstruídas.

Esses detalhes foram retirados do final da obra Todos contraD@nte, onde o autor explica o motivo sinistro que o teria levado a escrever uma história tão macabra e ao mesmo tempo tão verossímil na atualidade, pois,

Quem acredita nos direitos humanos procura transformar a possibilidade teórica em realidade, empenhando-se em fazer coincidir uma com a outra. Inversamente, um traço sinistro do nosso tempo é saber que é possível a solução de tantos problemas e no entanto não se empenhar nela (Candido, 2011, p.172).

Para tanto, Dill, que parece conhecer como ninguém o seu público, como também o ambiente propício da internet, sabendo a facilidade e aproximação entre essas duas pontas (jovens adolescentes e ambiente virtual), prepara um texto que narra a história de Dante, um garoto fora dos padrões estabelecidos por determinada sociedade, que lembra o ambiente virtual a que tanto está acostumado. 
O livro é retangular e a capa lembra um computador que está sendo iniciado ou encerrado, mas com uma mensagem em destaque, como se fosse um alerta. O nome do livro já chama a atenção para a história, como também para a escrita. Todos contra D@nte, mostra a guerra injusta de várias pessoas contra uma só, como também o nome Dante tem o “@” no lugar do “a”, mostrando em que lugar essa guerra está acontecendo. A mensagem subliminar já coloca o leitor dentro do ambiente em que a narrativa acontecerá.

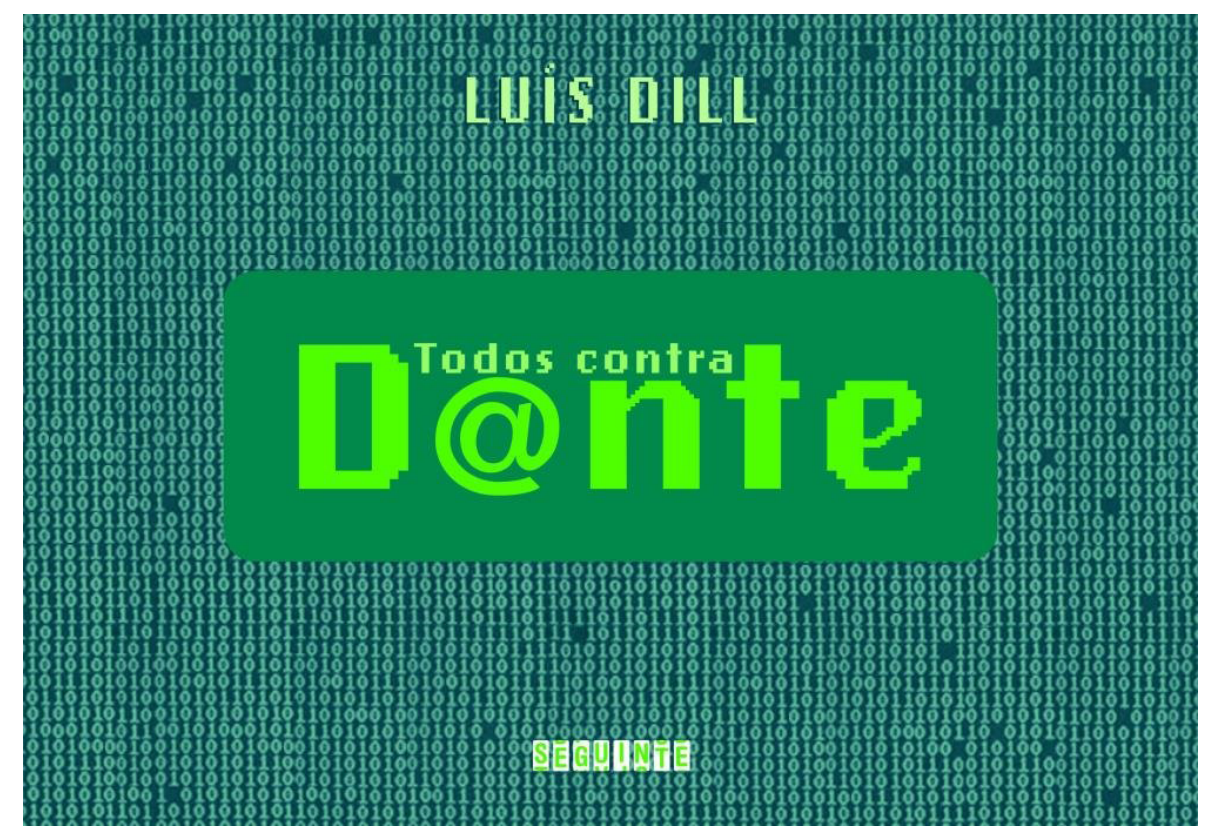

Imagem 01: Detalhe da capa de Todos contra D@nte

O livro é dividido em quatro partes, mas não segue uma linearidade na história. Segundo Lajolo e Zilberman (2017, p. 32), “o hipertexto favorece ainda a leitura não sequencial e não linear". Ele apresenta o "Link 1, 2, 3..." local onde o narrador conta a história, "Diálogo 1, 2, 3...”, onde acontecem as conversas entre os quatro envolvidos no espancamento do Dante, como também o diálogo desses com alguns amigos próximos, a Comunidade "Eu sacaneio o Dante", que é a página onde qualquer pessoa pode se inscrever para falar mal do Dante. Essa página é organizada e tem a descrição da página, idioma, categoria, dono, tipo, 
fórum, local, dia de criação e número de membros. O "Fórum" apresenta a temática do dia, como por exemplo: "defina o nariz do Dante", e dentro dessa temática, todos devem argumentar. A comunidade conta com 723 membros.

A última parte que a narrativa apresenta é o "Blog do Dante", onde escreve sobre suas frustrações, desejos e sonhos para seu xará florentino, Dante Alighieri.

Como já foi dito, a estrutura narrativa não mantém uma sequência dos acontecimentos. $\mathrm{O}$ narrador provoca no leitor um certo desejo de continuar a ler, pois não conta o fato ocorrido, vai descrevendo as situações que envolvem o fato. Cria um suspense através dos diálogos e links, contextualiza a situação do bulling através da Comunidade e do Blog e, só ao final, mostra o que realmente aconteceu, permitindo ao leitor refazer a história sequencial dentro do seu imaginário.

Na parte do livro denominada "link", a estrutura convida o jovem leitor a entrar no mundo imaginário do ciberespaço, como dando opção para conhecimento ou não da história: "Mais do que o texto impresso em papel, o hipertexto permite ao leitor-internauta percorrer caminhos próprios de leitura, na medida em que cabe a ele, através dos links que escolhe, eleger os atalhos e interagir" (Lajolo; Zilberman, 2017, p.32).

No link 1 , o narrador apresenta três dos quatro agressores, mas não conta o que aconteceu. Mostra que fazem parte de familias abastadas, pois havia um contraste entre o ambiente elitizado com o corpo estendido no capim. Tendo o leitor já conhecimento prévio do que acontece no mundo virtual, das agressões existentes no cotidiano, a estrutura do livro que o leva a pensar em um conflito entre partes pela internet e agora o fato real de um corpo estendido no capim, pode fazer com que esse leitor sinta a curiosidade de se manter ligado à obra, escolhendo o link que continua a narrativa, pois já foi criado um ambiente de suspense.

Logo após essa introdução a estrutura do texto dispõe para conhecimento do leitor o diálogo 1, que apresenta a conversa de Manuela e James, dois dos envolvidos, em que ela é apresentada como apreensiva e preocupada com o que fizeram, e ele, um garoto mimado, seguro de si, despreocupado e sabedor de que não terão problemas diante do que aconteceu. Isso instiga ainda mais 
a curiosidade do leitor frente a história, pois sabe que aconteceu algo grave e precisa descobrir o que foi. O leitor, nesse momento torna-se espectador dos fatos, como se ouvindo partes, para só depois tirar as suas próprias conclusões. Como afirma Candido, (2011, p.22), "se tomarmos o cuidado de considerar os fatores sociais no seu papel de formadores de estrutura, veremos que tanto eles quanto os psíquicos são decisivos para a análise literária”.

A Comunidade "Eu sacaneio o Dante" é mostrada em um primeiro momento dentro da estrutura de apresentação e posteriormente as falas permitem ao leitor enxergar a maldade das pessoas ao tratar tão mal um ser humano que têm os mesmos direitos que eles, porém que foge ao padrão social daquela instituição. Como lembra Candido (2011, p. 172), “todos sabemos que a nossa época é profundamente bárbara, embora se trate de uma barbárie ligada ao máximo de civilização".

Dentro dessa comunidade é possível ao leitor perceber que não somente os quatros envolvidos no ato brutal comungavam da ideia de humilhação do garoto que vinha de um bairro pobre, mas muitas outras pessoas, visivelmente de igual estirpe social.

Somente o Blog que Dante mantinha também na internet mostra um pouco da sua vivência e intelecto mais elevado. Nesse Blog ele conversa com Dante Alighieri, um dos mais importantes escritores humanistas do renascimento literário, considerado o maior escritor de língua italiana e um dos mais importantes da literatura universal, tendo sua principal obra, o famoso poema intitulado "A divina comédia".

Esse fato mostra que o personagem do livro de Luís Dill, embora pobre, tem um conhecimento elevado, bem diferente das outras personagens apresentadas. Ele dialoga com Dante Alighieri como a um amigo, tem intimidade com ele, contando sobre os fatos e novidades do mundo atual em comparação com o que o autor viveu na sua época.

$\mathrm{B} \log 5$

Caro xará florentino. Hoje recebi e-mail da minha Geovana. E-mail, meu amigo, é um tipo de carta que vem e vai pelo computador, aquelas máqui- 
nas aqui do século XXI de que já te falei. Imagino como tu devia ficar feliz quando recebia notícias da tua amada Beatriz. [link] Deixa eu dar um control-cê aqui (Dill, 2008, p.47).

Dante considera o escritor Dante como um amigo próximo, conhece suas histórias, aventuras e amores e, através desse diálogo no blog, o narrador consegue apresentar o perfil desse personagem como alguém inteligente e sensível, que está suportando e procurando vencer os desafios do desprezo e ataques dos colegas da escola, mas que também está no seu limite, até mesmo agindo como agressor num episódio que coloca a cabeça de um garoto na privada do banheiro, por tirar sarro dele e participar da Comunidade "Eu sacaneio o Dante".

O narrador destaca que Dante é um garoto da periferia, que seu pai abandonara a família quando ele era ainda muito pequeno e que sua mãe é uma mulher lutadora e que está conseguindo adquirir uma vida mais confortável através de muito trabalho em sua loja e que, por meio dessa loja, ela conseguiu matricular seu filho em uma das melhores escolas particulares daquela cidade, sem saber que lá ele sofreria o pior de seus pesadelos.

O blog também apresenta o irmão mais velho de Dante, um rapaz forte, alto e negro, a quem evita contar o que acontece no colégio, pois ele poderia defendê-lo através da violência.

Dentro dessa estrutura diferenciada, mais ajustada ao novo modelo de leitor virtual, o autor permite que a literatura discuta um tema muito relevante na atualidade, que é o bullying. A recepção da obra nesse caso está completamente ligada à noção de conhecimento prévio tanto da estrutura virtual, dos problemas vivenciados na internet, como também de autores já conhecidos e consagrados dentro da literatura dita universal. A partir desses conhecimentos dá-se a evolução do processo de construção da identidade não só dos personagens, como também do leitor.

A literatura é, pois, um sistema vivo de obras, agindo umas sobre as outras e sobre os leitores; e só vive na medida em que estes a vivem, decifrando-a, aceitando-a, deformando-a. A obra não é produto fixo, unívoco ante qualquer público; nem este é passivo, homogêneo, registrando uniformemente o 
seu efeito. São dois termos que atuam um sobre o outro, e aos quais se junta o autor, termo inicial desse processo de circulação literária, para configurar a realidade da literatura atuando no tempo (Candido, 2011, p. 84).

Dessa maneira o autor Luís Dill utiliza-se de uma nova ferramenta existente na sociedade para edificar sua estrutura literária e, com isso, parece querer atingir o público contemporâneo e levar o leitor à reflexão sobre problemas vivenciados no seu próprio tempo e espaço.

\section{Em busca de síntese...}

A literatura tem papel fundamental na vida do ser humano, representando o momento e contexto que se vive. Vimos que a literatura infantil nasceu junto à escola e foi se modificando à medida que ia se desenvolvendo.

O objeto livro teve um cunho pedagogizante em um passado não tão distante. Ele atendia às ideologias daqueles que detinham o poder e estava à mercê de um "mandonismo", de maneira que buscava o estabelecimento de padrões à criança de acordo com o desejo daqueles que patrocinavam a obra. Além disso, o livro sempre foi um objeto comercial. Mas ainda dentro dessa realidade, a história mostra que vários autores fugiram à regra e produziram uma obra esteticamente elaborada, levando o leitor à reflexão sobre o que já aconteceu na história, sobre as projeções futuras e, principalmente, buscando a reflexão sobre o meio que está inserido, pois a literatura não traz somente o que chamamos de bem ou de mal, mas aquilo que é necessário para o ser humano apreender as realidades que o cercam.

$\mathrm{Na}$ trajetória vista em Todos contra D@nte essas questões elencadas parecem muito fortemente marcadas por uma tentativa de apresentar justamente a diversidade de realidades existentes. Podemos compreender que a literatura, por ser viva, continua sofrendo mudanças e uma delas são os novos suportes que possibilitam novos modelos de estrutura textual e que, no caso de Dill, é o ciberespaço, a internet. Nesse espaço, os jovens leitores parecem sentir-se mais à vontade, pois esse novo mundo faz parte do seu cotidiano. Então alguns 
autores já se preocuparam em colocar essa realidade dentro de suas obras, seja usando esse suporte ou colocando a internet como tema.

Como visto, Luís Dill aproveitou esse nicho e produziu uma narrativa esteticamente elaborada, procurando colocar seu jovem leitor dentro de uma esfera já conhecida e com uma problemática também vivenciada por ele e, assim, permitindo uma reflexão sobre a atual situação nas escolas ou da vida dos jovens adolescentes em sociedade.

Podemos rematar, portanto, que a literatura, como durante todo o decorrer da sua história, vem cumprindo o seu papel de humanizar o leitor e permitir que reflita sobre a sua própria existência e sobre o mundo ao seu redor.

\section{Referências}

CANDIDO, Antonio. Literatura e sociedade. Estudos de Teoria e História literária. Rio de Janeiro: Ouro Sobre Azul, 2011.

. Vários Escritos. 5. Ed. Rio de Janeiro: Ouro Sobre Azul, 2011.

CUNHA, Maria Antonieta. Literatura Infantil: teoria e prática. 6 ed. São Paulo: Ática, 1987.

DILL, Luís. Todos contra D@nte. São Paulo: Companhia das Letras, 2008.

LAJOLO, Marisa; ZILBERMAN, Regina. Um Brasil para crianças: para conhecer a literatura infantil brasileira: história, autores e textos. 3 ed. São Paulo: Global, 1988.

LAJOLO, Marisa; ZILBERMAN, Regina. Literatura Infantil Brasileira: uma nova outra história. Curitiba: PUCPRESS, 2017.

LAJOLO, Marisa; ZILBERMAN, Regina. A formação da leitura no Brasil. São Paulo: Editora Unesp, 2019.

WALSH, Robert. Noticias do Brasil, Belo Horizonte: Itatiaia. São Paulo: Edusp, 1985. 


\section{CAPÍTULO 7. A OFERTA DA LÍNGUA ESPANHOLA EM ESCOLAS DA REDE PÚBLICA ESTADUAL DE ENSINO DA CIDADE DE PORTO VELHO-RO}

Tiago Carvalho Da Silva

Luciana Pitwak Machado Silva Prates

\section{Introdução}

Este artigo é resultante de parte de um estudo desenvolvido como requisito para a obtenção do título de Licenciado em Letras-Espanhol, a partir de uma pesquisa realizada nas escolas da rede estadual de ensino da cidade de Porto Velho-RO, que tem como principal objetivo verificar a situação da oferta da língua espanhola a partir da amostra de 04 instituições, localizadas em diferentes regiões da cidade: zona norte, zona sul, zona leste e zona central. Para tanto, procurou-se buscar informações na Secretaria de Educação de Rondônia-SEDUC e apresentar questionário nas escolas selecionadas para a coleta de dados.

A pesquisa ora apresentada teve início pela importância de se saber as consequências imediatas decorrentes das mudanças das leis que regem a oferta da língua espanhola no país a partir da aprovação da Medida Provisória MP 746/17, revogando a Lei Federal 11.161/05 e LDB 9394/96 e, consequentemente, as Resoluções e Portarias regionais, tornando-se necessário averiguar como a oferta da língua espanhola seria. A fim de se obter um resultado mais amplo da situação da oferta na cidade, optou-se por fazer um mapeamento das escolas da rede pública estadual de ensino, a partir da planilha de escolas que oferecem a língua, apresentada pela SEDUC. Após o mapeamento foram selecionadas 4 escolas localizadas em diferentes regiões da cidade para se obter um panorama por amostragem.

O critério de seleção foi, primeiramente, as escolas que estivessem localizadas em diferentes regiões da cidade e, em seguida, as que sempre ofereceram a língua, desde 2011 até 2016. A escolha do ano de 2011, deu-se a partir 
da inquietação do autor da monografia, sobre a situação da língua espanhola naquele ano, após a conclusão do ensino médio. Durante a graduação em letras/espanhol, surgiu então a curiosidade de se pesquisar mais sobre a situação da oferta da disciplina de língua espanhola nos anos posteriores.

Por meio de questionário apresentado à direção e professor de espanhol da escola, buscou-se saber como os alunos da rede pública estadual estão tendo acesso ao ensino da língua espanhola, bem como de que forma estão organizados os horários da disciplina. Partiu-se das hipóteses da pesquisa: a) O Ensino de Língua espanhola está sendo ofertado em todas as escolas do sistema público estadual da cidade de Porto Velho; b) Em algumas escolas do sistema público estadual da cidade de Porto Velho não está sendo ofertado, devido a algumas escolas adotarem o ensino da língua inglesa e por isso não há o ensino de língua espanhola; c) há escolas que não ofertam a disciplina de língua espanhola porque não há pessoas capacitadas para atuar.

\section{O ensino da língua espanhola no Brasil}

Ao tratar sobre o ensino de línguas, é inevitável mencionar algumas características que estão presentes nas sociedades, tais como: interesses econômicos, sociais e políticos, que culminam na necessidade de se estudar uma ou mais línguas estrangeiras. Com isso, tais interesses determinam o modelo educacional ideal para si no ensino dessas línguas, ficando a cargo do Estado determinar aquela que seja de maior importância.

Considerando o anteriormente exposto, por uma questão geográfica e política, o Brasil apresenta a necessidade de se estudar pelo menos duas línguas estrangeiras nas escolas: inglês e espanhol, já que politicamente mantém relações internacionais e faz parte do MERCOSUL, além e estar rodeado por vários países cujo idioma oficial é o espanhol.

Trazendo uma contextualização histórica, o ensino da língua espanhola teve início com a instalação do Colégio Pedro II, fundado em 2 de dezembro de 1837, porém as aulas começaram de fato em 1838. Segundo Martinéz e Laseca, (2008, p. 53) “As matérias eram: Latim, grego, francês e Inglês. Em 1919, 
o Italiano se torna obrigatório e o Espanhol sendo introduzido como matéria optativa." Alguns anos mais tarde, ocorreram duas reformas no sistema educativo brasileiro. A primeira reforma foi a Reforma Francisco Campos e a segunda foi a Reforma de Capanema. A Reforma Francisco Campos ocorreu segundo Martinéz e Laseca (2008, p. 54):

Com a chegada ao poder de Getúlio Vargas em 1930, o Brasil inicia uma campanha de nacionalização da Educação conhecida como reforma Francisco de Campos (Ministro da Educação desde 1930), a qual, como era possível, afetou especialmente tanto as escolas de imigrantes como o Ensino de Língua Estrangeira.

Assim, essa reforma foi muito importante para a estrutura organizacional do ensino no país como, a estruturação das universidades e da criação do Conselho Nacional de Educação. Embora essa reforma tenha contemplando importantes avanços na educação do país, ela trouxe, também, em seu bojo uma política de educação seletiva e discriminatória, e assim afetando, entre outras, as escolas dos imigrantes, e consequentemente o Ensino de Línguas Estrangeiras.

A Reforma de Capanema dividiu o Ensino secundário em dois ciclos, o Ginásio e o Colegial. Neste período o Ensino de línguas Estrangeiras se fortaleceu bastante, pois o ensino do Latim, Francês e Inglês torna-se obrigatório no Ginásio, e no Colegial, o Francês, o Inglês e o Espanhol. Tentativa de vincular as Línguas Estrangeiras no Currículo Brasileiro.

Para Martinéz e Laseca (2008, p. 56) a reforma de Capanema ficou marcada como um período que se obteve a primeira tentativa de vincular as Línguas Estrangeiras no Currículo Brasileiro, em que se buscava introduzir métodos avançados no Ensino das Línguas Estrangeiras Modernas. Depois de anos de debate, segundo Martinéz e Laseca (2008, p. 57), surge a primeira Lei de Diretrizes e Base da Educação Brasileira, promulgada em 1961 com o no 4.024, que, entre outras determinações, deixava a cargo dos Estados a inclusão ou não das disciplinas de Línguas Estrangeiras, ou seja, não existe mais a obrigatoriedade. A referida lei encarrega o Conselho Federal de Educação de ordenar sobre as matérias obrigatórias, que segundo Martinéz e Laseca, (2008, p. 57): 
O conselho federal de Educação ao determinar como matérias obrigatórias as de Português, Matemática, Geografia, História e Ciências, as línguas Estrangeiras ficaram fora do currículo obrigatório, passando à categoria de matérias optativas ou complementares.

A LDB de 1971 não trouxe, efetivamente, nenhuma mudança ao Ensino de Língua Estrangeira, que foi literalmente esquecida. No entanto, o Inglês era o que mais recebia atenção, e o Espanhol estava quase fora do sistema de ensino brasileiro. Porém, com a criação das associações dos professores de Espanhol, segundo Martinéz e Laseca (2008, p. 57), o sistema foi aos poucos sendo incluído nos currículos dos Estados e, portanto, conseguindo que aparecesse dentre as opções de Língua Estrangeira do Vestibular.

A LDB de 1996, segundo Martinéz e Laseca, (2008, p. 60) devolve à Língua Estrangeira a obrigatoriedade a partir da quinta série do Ensino Fundamental, e no Ensino Médio estabelece no Art. 36 § 30, que será incluída uma Língua Estrangeira Moderna, como disciplina obrigatória, escolhida pela comunidade escolar, e uma segunda, optativa, dentro das possibilidades centro escolar.

No entanto, as orientações para escolher qual matéria seria obrigatória e qual seria optativa, deveriam seguir os critérios dos Parâmetros Curriculares Nacionais de Língua Estrangeira (PCNs), entretanto, pouca coisa mudou com relação à obrigatoriedade do Ensino de Línguas Estrangeiras, permanecendo o Inglês, que já se mantinha em um lugar privilegiado no sistema.

Segundo Martinéz e Laseca (2008, p. 61), somente após a criação do MERCOSUL, cujos países pertencentes são Argentina, Paraguai, Uruguai e Brasil, o ensino do Espanhol, que ocupava um lugar secundário, começa a ganhar força, e esse processo culmina na aprovação da denominada "Lei do Espanhol", conforme podemos observar em Sedycias (2005:19):

El Mercado Común del Sur, al que pertenecen Argentina, Paraguay y Uruguay, además de Brasil, se creó con la firma del Tratado de Asunción y hasta ahora ha servido principalmente de instrumento para el desarrollo de una unión aduanera. Entre sus objetivos están los de crear medios para ampliar las actuales dimensiones de los mercados nacionales, potenciar, sobre esta 
base, el desarrollo económico con justicia social y desarrollar el aprovechamiento de los recursos disponibles en la región, preservando el medio ambiente y mejorando los medios de transporte y comunicación.

A "Lei do Espanhol”, como ficou conhecida, foi um resultado de várias discussões de projetos de lei enviado à câmara dos deputados, até que o então deputado, Átila Lira, autor e relator do projeto de lei 3.987/2000, que se tratava do ensino do espanhol, sugere o início da tramitação parlamentar do referido, que segundo Martinéz e Laseca, (2008, p. 65) cinco anos depois se converte na Lei 11.161/2005, que torna obrigatório a oferta da disciplina de Língua Espanhola nas Escolas do Ensino Médio, porém de livre escolha para os alunos, cabendo às escolas da rede pública e privada incluírem o Espanhol obrigatoriamente em seus currículos. No entanto, houve muitas controvérsias com relação à referida lei, mas que não serão tratadas aqui, detalhadamente, por não serem de relevância significativa para o objeto deste trabalho.

\section{Evolução da oferta da língua espanhola e suas bases legais}

Com a Reforma de Capanema, em 1942, imposta pelo ministro da Educação e Saúde Gustavo Capanema, a oferta da língua espanhola se tornou obrigatória e foi inserida no Currículo do Ensino Médio. Essa reforma tinha como objetivos a reestruturação da educação nacional e dar importância às disciplinas clássicas (Grego e Latim) e modernas (Inglês, Francês e Espanhol) (Araújo, 2010, p. 242).

Mais tarde, com a implementação da Lei de Diretrizes e Bases em 1961, as disciplinas clássicas e modernas, impostas pela Reforma de Capanema em 1942, não são citadas em seu texto, trazendo assim uma desigualdade no ensino de línguas estrangeiras entre a classe favorecida e a menos favorecida, porque só as famílias que tinham um poder aquisitivo maior buscavam conhecimentos de língua estrangeiras através de instituições de idiomas ou de um professor particular e a classe de famílias menos favorecidas só detinham o poder de estudar conhecimentos básicos oferecidos nas escolas: Português, Matemática, Geografia, Ciências e História. (Sauders apud Campos; Machado, 2017). 
A responsabilidade do ensino de línguas estrangeiras, segundo a LDB/61, é deixado a cargo dos conselhos estaduais de educação, na qual estes detinham o poder de optar pela língua a ser ensinada e realizarem reformas educacionais necessárias, logo o ensino da língua espanhola "não teve muito prestígio uma vez que as legislações, projetos e reformas educacionais deixaram a cargo dos Estados a escolha da língua a ser ensinada, e quando houve obrigatoriedade do ensino do Espanhol sua carga horária foi mínima, tornando-se irrelevante" (Araújo, 2010, p. 242). Em 1976, o ensino de línguas estrangeiras, através da resolução 58/76, se torna obrigatório para o antigo colegial (Ensino Médio), deixando de fora o ginásio (Ensino Fundamental) (Araújo, 2010, p. 243b).

Após 15 anos da implementação da LDB de 1961, o ensino de línguas estrangeiras é posto como obrigatório e posteriormente os alunos das instituições públicas passaram a ter acesso à aprendizagem de uma segunda língua. No ano de 1996, foi implementada a nova LDB, que incluía o ensino de línguas estrangeiras, tornando obrigatória a oferta a partir da antiga $5^{\circ}$ série, atualmente $6^{\circ}$ ano, "Na parte diversificada do currículo será incluído, obrigatoriamente, a partir da quinta série, o ensino de pelo menos uma língua estrangeira moderna, cuja escolha ficará a cargo da comunidade escolar, dentro das possibilidades da instituição" (\$5 LDB 9394/1996). No ensino médio, também é decretada a obrigatoriedade do ensino de língua estrangeira e uma segunda se torna de caráter facultativo "será incluída uma língua estrangeira moderna, como disciplina obrigatória, escolhida pela comunidade escolar, e uma segunda, em caráter optativo, dentro das disponibilidades da instituição. (Art. 36 III, LDB, 1996).

Com o crescimento da língua espanhola, em 2005, através da lei $\mathrm{n}^{0}$ $11.161 / 2005$, o ensino do idioma se tornou obrigatório nas escolas de ensino médio e o prazo para o cumprimento da lei foi de 5 anos, ou seja, o prazo terminou em 2010. A lei foi sancionada pelo então presidente da República Luiz Inácio Lula da Silva: “[...] a Lei 11.161/2005, a qual torna obrigatória a oferta do espanhol nas escolas de Ensino Médio, sendo que o prazo para cumprir essa determinação expirou em 2010 [...]”. (Araújo, 2010, p.247). 
No dia 16 de fevereiro de 2017, a Medida Provisória 746/17 foi sancionada pelo então Presidente da República Michel Temer, sob a Lei 13.415 de 16 de Fevereiro de 2017, que alterou e acrescentou alguns artigos da LDB 9394/96, de 20 de Dezembro de 1996 (Lei de Diretrizes e Bases da Educação Nacional). Com relação ao ensino de línguas estrangeiras, a Medida Provisória alterou o Artigo 26-a, da LDB em que incluiu o ensino da língua inglesa como oferta obrigatória na modalidade do ensino fundamental: "No currículo do ensino fundamental, a partir do sexto ano, será ofertada a língua inglesa” ( $\$ 5^{\circ}$, art.2, MP 746/17).

Na Modalidade do Ensino Médio, a Medida Provisória 746/17, em seu artigo $2^{0}, \S 4^{\circ}$, alterou o art. 26 da Lei de Diretrizes e Bases da Educação Nacional incluiu a Língua Inglesa como disciplina obrigatória e a disciplina de Língua Espanhola se tornou optativa de caráter preferencial "Os currículos do ensino médio incluirão, obrigatoriamente, o estudo da língua inglesa e poderão ofertar outras línguas estrangeiras, em caráter optativo, preferencialmente o espanhol, de acordo com a disponibilidade de oferta, locais e horários definidos pelos sistemas de ensino" ( $\$ 4^{\circ}$, Art.2, MP 746/17).

Com o crescimento das informações, o indivíduo precisa estar atualizado para acompanhar a progressão de novos conhecimentos. A aprendizagem de um idioma estrangeiro é imprescindível para a sociedade adquirir novos conhecimentos acerca do mundo globalizado.

A língua espanhola é o idioma oficial de 20 países, que estão localizados nos seguintes continentes: Europa, África, América do Norte (México), América Central e América do Sul, sendo que os países que fazem fronteira com o Brasil e que tem como idioma oficial a língua espanhola são: Colômbia, Venezuela, Paraguai, Argentina, Bolívia e Peru. Os países Chile e Equador, apesar de estarem localizados na América do Sul, não fazem fronteira com o Brasil.

A partir dos anos 1990, as relações comerciais entre Brasil, Argentina, Paraguai, Uruguai, cresceram de forma significativa, com a implementação do Mercado Comum do Sul, através do Tratado de Assunção realizado no ano de 1991, que tinha por objetivo principal aprimorar mais os negócios de mercado entre os países membros. Com o passar dos anos, o crescimento aumentou de 
forma significativa e a partir de então surgiu, no Brasil, a necessidade em se aprender a língua espanhola para aprimorar mais o idioma para posteriormente utilizá-lo nas relações comerciais entre os países vizinhos.

Nos Parâmetros Curriculares Nacionais (PCN), em seu texto, afirma-se que com a chegada do Mercosul, a aprendizagem da Língua Espanhola no Brasil é cada vez mais presente nas regiões fronteiriças e, a partir de então, o ensino da língua espanhola foi incluído nos currículos escolares corroborando com a afirmação de que a aprendizagem da língua portuguesa nos países que falam a língua espanhola é cada vez mais crescente, pois os habitantes estão em contato com a pluralidade cultural entre os países, tanto os que falam a língua espanhola, quanto o Brasil, que tem como idioma oficial a língua portuguesa.

[...] é notável a presença, cada vez maior, do espanhol no Brasil. Sua crescente importância, devido ao Mercosul, tem determinado sua inclusão nos currículos escolares, principalmente nos estados limítrofes com países onde o espanhol é falado. A aprendizagem do espanhol no Brasil e do português nos países de língua espanhola na América é também um meio de fortalecimento da América Latina, pois seus habitantes passam a se (re) conhecerem não só como uma força cultural expressiva e múltipla, mas também política (um bloco de nações que podem influenciar a política internacional). (PCN,1998, p.50)

Para regulamentar o Ensino da Língua Espanhola no Brasil, o Presidente da República Luiz Inácio Lula da Silva sancionou a Lei $n^{0} 11.161 / 05$ de 05 de agosto de 2005, que tornava obrigatória a oferta do ensino da língua espanhola para o Ensino Médio, tornando facultativa a oferta para o ensino fundamental. “O ensino da língua espanhola, de oferta obrigatória pela escola e de matrícula facultativa para o aluno, será implantado, gradativamente, nos currículos plenos do ensino médio.” (Lei 11.161/05). Nesta legislação estavam inclusas as redes públicas e privadas de ensino, em que segundo a Lei, deveriam oferecer o ensino da Língua Espanhola de forma estratégica e regular dentro do horário normal das aulas.

Art. 3o Os sistemas públicos de ensino implantarão Centros de Ensino de Língua Estrangeira, cuja programação incluirá, necessariamente, a oferta de língua espanhola. 
Art. 4o A rede privada poderá tornar disponível esta oferta por meio de diferentes estratégias que incluam desde aulas convencionais no horário normal dos alunos até a matrícula em cursos e Centro de Estudos de Língua Moderna. (LEI 11.161/05)

A partir do ano de 2010, a Secretaria do Estado da Educação de Rondônia-SEDUC, a fim de cumprir a lei $\mathrm{n}^{0} 11.161 / 05$, sancionada pelo então Presidente da República Luiz Inácio Lula da Silva, publicou a Portaria Estadual $n^{0} 0130 / 10$, de 03 de Fevereiro de 2010, que visava à regulamentação da oferta obrigatória da Língua Espanhola por parte das escolas estaduais.

No texto da portaria da Seduc $n^{0} 0130 / 10$, assim como o texto da lei $n^{0} 11.161 / 05$, faculta ao aluno fazer a disciplina: "A Língua Espanhola terá tratamento de disciplina obrigatória pela escola, sendo de matricula facultativa para o aluno, observada a exceção prevista nesta portaria" (Portaria Seduc n 0130/10, p. 01).

A inclusão no currículo escolar "Na Grade Curricular do Ensino Médio-Regular e Suplência, a Língua Espanhola, com uma aula semanal será incluída na parte diversificada e fora da carga horária mínima prevista para a série escolar" (Portaria Seduc n 0130/10, p. 01).

A regulamentação da disciplina da Língua Espanhola com relação ao horário, em que as escolas deveriam cumprir, segundo o texto da portaria n 0130/10 "A Língua Espanhola deverá ser ofertada no horário regular de matricula do aluno, podendo ser ministrada numa pré aula ou pós aula".

Outro ponto a ser destacado no texto da Portaria é que as escolas eram obrigadas a elaborar projetos ligados ao ensino de língua espanhola: "As escolas que desejarem organizar turmas ou classes com alunos de series/anos escolares distintos para a oferta da língua espanhola deverão elaborar propostas de operacionalização e encaminhar as Representações de Ensino para conhecimento e apreciação. (Portaria Seduc n 0130/10, p. 02). Podemos observar que, através da Aprovação da Lei 11.161/2005, o Governo de Rondônia, por meio da Secretaria do Estado da Educação (Seduc), criou imediatamente uma legislação que ampara a língua espanhola nas escolas, nas quais impõe às ins- 
tituições ofertar de maneira obrigatória o ensino do espanhol na rede pública estadual. A seguir, será mostrado como está sendo ofertada a língua espanhola na cidade, nas instituições mantidas pelo Governo de Rondônia.

\section{A oferta de língua espanhola em escolas públicas estaduais da cidade de Porto Velho}

O Governo de Rondônia, segundo informação apresentada pela Secretaria de Educação do Estado-SEDUC, possui 87 escolas estaduais ativas (2016) localizadas dentro das zonas urbana e rural do município de Porto Velho, incluindo ainda os seus distritos: Jaci-Paraná e Nova Califórnia entretanto, deste quantitativo, apenas 57 ofereceram a língua espanhola entre os anos 2011 e 2016. Dessas instituições, 30 escolas não ofereceram a disciplina de língua espanhola porque são instituições de ensino infantil, ainda sob a responsabilidade do governo do Estado. Segundo o que foi relatado pelo técnico da Secretaria do Estado da Educação (Seduc), o governo do estado está passando a responsabilidade a Prefeitura de Porto Velho. É importante ressaltar que não foi possível obter os dados do ano de 2017, pois ainda o levantamento de dados está sendo em fase de conclusão por parte da SEDUC e que, conforme informado em entrevista, ainda não foi concluído em razão das mudanças decorrentes da Medida Provisória 746/17, que revoga a Lei 11.161/2005, que regulamentava a oferta da língua espanhola como facultativa ao aluno e obrigatória para a escola.

Além da Lei 11.161/2005, tal Medida alterou e acrescentou alguns artigos da LDB 9394/96, que também tratava da oferta de línguas estrangeiras na qual a Lei 11.161/2005 regulamentava o ensino da língua espanhola nas instituições públicas e privadas. "Na parte diversificada do currículo será incluído, obrigatoriamente, a partir da quinta série, o ensino de pelo menos uma língua estrangeira moderna, cuja escolha ficará a cargo da comunidade escolar, dentro das possibilidades da instituição" (Art. 26, §5 LDB9394/96). Em razão das leis vigentes até 2016, o ensino da língua espanhola era mantido pelas escolas de forma obrigatória, facultando ao aluno sua matrícula. 
Durante a investigação, foi necessário solicitar à SEDUC informações relacionadas à quantidade de escolas existentes na cidade de Porto Velho, bem como, quantas e quais oferecem a língua espanhola, além de saber onde estão localizadas a fim de se fazer uma pesquisa de campo nas mesmas. É importante frisarmos que não foi possível realizar a pesquisa de nas escolas que oferecem a língua espanhola nos distritos de Nova Califórnia e Abunã e nas instituições da zona rural devido ao pouco tempo disponibilizado para se elaborar a pesquisa de campo.

Foi criado um gráfico, denominado de gráfico 1, que mostra o quantitativo de escolas que ofertavam a disciplina de Língua Espanhola durante os anos de 2011 a 2016 e, em seguida, foram criadas tabelas que mostram as instituições localizadas em cada uma das zonas mapeadas, divididas entre: Zona Urbana, contendo as escolas localizadas em cada uma das regiões da cidade (tabelas de 1 a 4); Distritos: contendo as escolas localizadas nos distritos de Porto Velho (tabela 5) e; Zona Rural, contendo as escolas localizadas na zona rural da cidade (tabela 6).

Para a efetivação da pesquisa de campo, foi escolhida uma escola de cada uma das 4 regiões da cidade, considerando apenas as que estão localizadas na zona urbana e que, segundo informação da SEDUC, sempre ofereceram a língua espanhola na grade curricular desde 2011 até o ano de 2016 e que estão inseridas nas tabelas conforme: Tabela 1 (Instituições localizadas na zona norte), Tabela 2 (Escolas localizadas na zona sul), Tabela 3 (Instituições localizadas na zona leste), Tabela 4 (Escolas localizadas na zona central).

Do total de escolas apresentadas pela SEDUC, 57 oferecem o espanhol como língua estrangeira desde 2011, tendo sofrido variações de oferta a cada ano, conforme pode ser observado no gráfico abaixo. 
Gráfico 1: Variações das 57 escolas que oferecem a língua espanhola no período de 2011 a 2016.

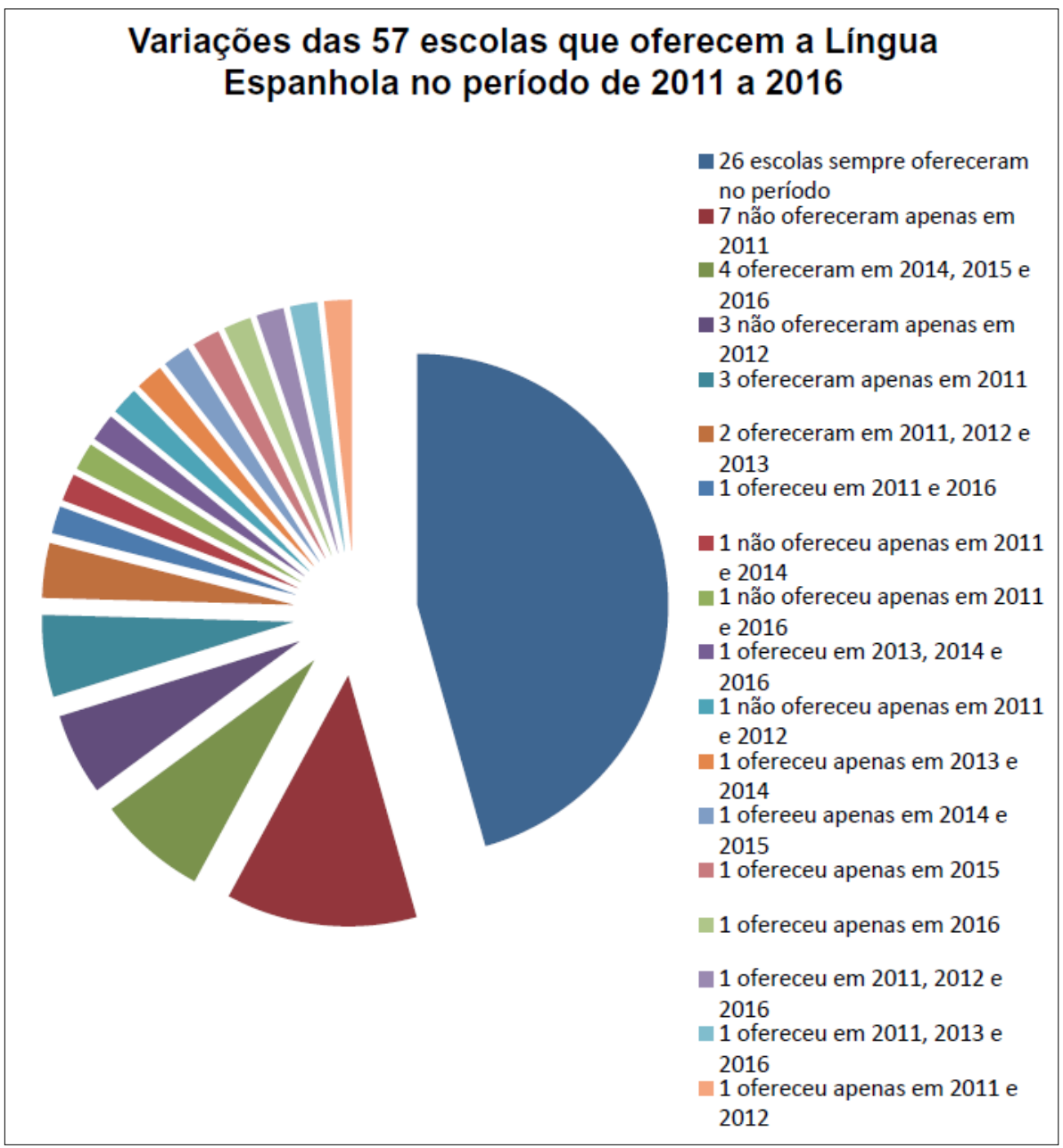

Fonte: elaborado pelos autores

Em referência às informações contidas no gráfico 1 acima, que tratam do total de escolas da rede pública estadual de ensino localizadas na cidade de Porto Velho/RO e que ofertavam a Língua Espanhola durante os anos de 2011 a 2016 (57 escolas), conforme cada zona, divididas por região, incluindo as localizadas nos distritos que fazem parte do município de Porto Velho, bem como as escolas localizadas na zona rural. 


\section{Dados coletados}

Nesta fase da pesquisa, foram levadas algumas questões a 4 escolas localizadas em diferentes regiões da cidade a fim de se apurar como está sendo ofertada a língua, tendo essas escolas como amostra para o que pode estar acontecendo nas demais com relação ao ensino do espanhol como língua estrangeira em escolas públicas da cidade de Porto Velho/RO.

Foram escolhidas 4 escolas públicas da rede estadual de ensino localizadas na cidade de Porto Velho/RO, em diferentes regiões da cidade: Zona Norte, Zona Leste, Zona Sul e Zona Central, a fim de se obter uma visão geral, a partir das escolas selecionadas, sobre como está acontecendo a oferta do ensino da língua espanhola na cidade, tendo como critério de seleção, além de estarem em diferentes regiões da cidade, as mesmas sempre ofertaram a língua espanhola desde o ano 2011.

Para fins de preservar a identidade das escolas visitadas para a coleta de dados, as denominaremos aqui como escola: A, B, C e D.

\subsection{Analise das questões apresentadas}

A Primeira Questão tem por objetivo saber dos gestores e professores de espanhol das escolas, como está sendo ofertada a disciplina de língua espanhola, se está sendo na pré-aula ou pós-aula, ou está inserida na grade curricular dos alunos, bem como se esta oferta se dá no Ensino Fundamental/Médio/ Educação de Jovens e Adultos-EJA.

A partir das respostas apresentadas, tanto da direção da escola como do seu professor, podemos perceber que o ensino de língua espanhola, nas 4 instituições de ensino, tem visões diferentes.

$\mathrm{Na}$ escola A, o ensino de língua espanhola é ofertado no horário pré-aula para os alunos do ensino médio regular e pós-aula para os alunos do EJA, ou seja, a matricula é facultativa aos alunos e para cursar a disciplina ele precisa estar antes ou ficar após a aula regular.

$\mathrm{Na}$ escola $\mathrm{B}$, o ensino de língua espanhola é ofertado aos alunos 2 vezes na semana, com aulas de 48 minutos, pois a escola funciona em tempo integral; 
porém, por essa razão, é obrigatório que os alunos cursem a disciplina, pois está dentro da grade e os alunos estão matriculados automaticamente.

$\mathrm{Na}$ escola $\mathrm{C}$, a disciplina de língua espanhola é ofertada de maneira opcional, no ato da matricula o aluno deve escolher qual das duas disciplinas de língua estrangeira oferecidas pela escola: inglês ou espanhol, ele quer fazer. Cada disciplina tem sua sala específica, chamadas pela escola de laboratórios ou oficinas. A língua espanhola está dentro do horário regular de aula sendo ofertada apenas para os alunos do ensino médio regular e para o EJA.

$\mathrm{Na}$ escola $\mathrm{D}$, a oferta da língua espanhola está dentro do horário normal de aula, 1 vez por semana, para os alunos do ensino médio regular e para o EJA.

\section{Considerações Finais}

A pesquisa desenvolvida se deu a partir da curiosidade em saber como está a situação da oferta da língua espanhola na rede pública estadual de ensino da cidade de Porto Velho, após a aprovação da Medida Provisória $746 / 2017$, na qual se buscou resolver a seguinte questão problema: Como está a situação da língua espanhola na rede pública estadual de ensino na cidade de Porto Velho-RO?

A investigação teve caráter qualitativo, tendo sido apresentado uma visão geral das leis que regem a oferta da língua espanhola no país e na região, seguida de pesquisa de campo, divididas em 02 fases: a primeira se deu pela busca de dados junto a Secretaria do Estado da Educação de Rondônia-SEDUC, que forneceu as informações necessárias para se saber a quantidade de escolas ativas existentes na cidade de Porto Velho, considerando também a zona rural e os distritos, sendo informado ainda, pela SEDUC, as escolas que ofereceram a disciplina língua espanhola no período de 2011 a 2016. A segunda fase se deu através da coleta de dados tendo sido visitadas 04 instituições públicas de ensino da rede estadual, localizadas nas diferentes regiões da zona urbana considerando, regiões norte, sul, leste e central da cidade de Poro Velho, nas quais foi aplicado um questionário direcionado aos diretores e professores das referidas instituições. 
Os dados resultantes da análise das respostas do questionário comprovam que do total das instituições investigadas, 01 oferta a disciplina de língua espanhola no horário de pré- aula para os alunos matriculados no ensino regular e pós aula para os alunos matriculados no EJA, sendo oferecida em caráter optativo para o aluno; 01 oferece a o espanhol dentro do horário regular, duas vezes na semana como disciplina obrigatória por trabalhar período integral; 01 oferece dentro do horário regular mas em caráter optativo ao aluno simultâneo ao inglês; 01 oferece em caráter optativo, dentro do horário regular.

Podemos observar que cada escola trabalha de uma forma diferente, tentando seguir o que se estabelece nas leis de oferta do espanhol, entretanto, cada escola faz sua própria interpretação, não tendo uma regra padrão pré-estabelecida.

Outro ponto a destacar é que das 03 instituições que a ofertam de maneira obrigatória, onde a disciplina é incluída na grade curricular dos alunos, oferecendo a disciplina duas vezes na semana, 01 oferta de maneira opcional, onde a disciplina possui o mesmo horário da língua inglesa, sendo aplicada de forma simultânea, e 02 ofertam as disciplinas de língua inglesa e espanhola em horários diferentes, porém dentro da grade curricular, sendo que uma o faz em caráter optativo e outra em caráter obrigatório.

Quanto ao recebimento da disciplina pela escola através dos alunos, 01 instituição, especificamente a que oferece na modalidade de pré e pós-aula, apresentou uma desvalorização da língua espanhola por parte dos discentes e 03 instituições apesentaram uma valorização muito grande por parte dos alunos, independentemente de a oferta ser em caráter obrigatório, dentro da grade, ou opcional ao aluno.

Ainda com relação à análise de dados, foi observado que as escolas pretendem continuar oferecendo a disciplina no ano de 2018, mesmo com a alteração das leis que amparam a oferta da língua espanhola para uma modalidade totalmente opcional tanto ao aluno quanto à escola.

Percebeu-se, ainda, que todos os professores das instituições pesquisadas são habilitados para ministrar a disciplina de língua espanhola, sendo que 01 é formado na UFAC e 03 na UNIR, o que mostra a importante contribuição do 
Curso de Letras Espanhol para o fortalecimento e atendimento à comunidade escolar para cumprir com a proposta de ensino da língua espanhola nas escolas.

Nota-se que algumas hipóteses foram confirmadas quando do início da pesquisa, como, por exemplo, que nem todas as instituições informadas pela SEDUC oferecem a disciplina de língua espanhola, mas, em todas as pesquisadas, há professores formados na área de língua espanhola e que o horário da disciplina está dentro da grade curricular, salvo exceção de uma instituição que oferta a disciplina no horário de pré e pós-aula.

Observou-se ainda que em 03 escolas onde a língua está inserida na grade curricular, foi apresentado interesse do aluno em estudá-la, independente de a forma de oferta ser optativa ou obrigatória para o aluno, ficando, nessas distintas situações, a cargo do professor estimular o interesse de aluno em participar do processo de ensino-aprendizagem, além de apenas optar por se matricular na disciplina em questão.

$\mathrm{Na}$ escola onde a oferta se dá na pré ou pós-aula, foi detectado que o interesse não é grande, primeiro por ser opcional ao aluno, segundo pelas dificuldades logísticas de chegar antes ou ficar após a aula, devido a diversas situações, como o aluno morar longe da escola e dificuldade em condução para o horário de chegada e/ou saída da escola.

Acredita-se que, ainda que a oferta fosse mantida na pré e pós-aula, nesses casos, a adesão seria maior se houvesse uma obrigatoriedade no estudo dessa disciplina, considerando a informação prestada pela escola $\mathrm{C}$, de que quando a disciplina era oferecida no $5^{\circ}$ tempo não havia muita procura, entretanto, os alunos sempre pediam que a mesma fosse inserida no horário regular para que eles pudessem cursá-la e, segundo informado pela escola, após a mesma haver alterado a forma de oferta do $5^{\circ}$ tempo para dentro do horário regular, em caráter optativo ao aluno, simultâneo ao inglês, a procura foi bem maior.

Espera-se que esta pesquisa possa contribuir para o ensino da língua espanhola, pois o mostra a realidade atual da disciplina nas instituições da rede pública estadual de ensino da cidade de Porto Velho. 
Podemos observar que as instituições investigadas mostram interesse em ofertar a disciplina de língua espanhola de maneira opcional ou não e comprova-se que a disciplina de língua espanhola está sendo procurada pelos alunos, principalmente quando inserida no horário regular, tendo menos adesão na oferta no pré e pós aula, nestes casos procura sua matrícula apenas quando o aluno precisa do conhecimento para efetuar o Exame Nacional do Ensino Médio (ENEM).

Também, espera-se que este trabalho possa ajudar pesquisadores, sobretudo os acadêmicos do curso de letras/espanhol da Universidade Federal de Rondônia, ao estimulo a pesquisar sobre o ensino da língua espanhola na cidade de Porto Velho, bem como apresentar propostas de políticas públicas para regimentar uma estrutura apropriada e padronizada de oferta que envolva alunos, professores e Instituições de Ensino, sejam elas públicas ou particulares em seus diferentes segmentos, sejam eles: Federal, Estadual ou Municipal.

\section{Referências}

ARAÚJO, A, M, Catya. O ensino de Espanhol no Brasil: História de um processo em construção. 2010. Disponível em: http://www.uel.br/eventos/sepech/ $\operatorname{arqtxt} / \mathrm{PDF} /$ catyamarques.pdf.

Acesso: 01/09/2017

L.D.B. Lei de Diretrizes e Bases da Educação Nacional. 2011. Brasília. $6^{0}$ Edição. Edições Câmera.

LEI 11.161/2005. Legislação sobre a Língua Espanhola. Câmera Federal. Disponível em: www.camera.gov.br

MEDIDA PRÓVISÓRIA 746/17. Câmera Federal. 2017. Disponível em: www.camera.gov.br

MONTAÑEZ, P. Amanda. A implantação da língua espanhola nas escolas da cidade de Londrina e Região: Politicas Públicas e Educação Bílingue. Disponível em: www.uel.br Acesso em: 12/10/2017 
PORTARIA 0130/2010. O ensino da Língua Espanhola. Gabinete Secretaria de Estado da Educação. Governo de Rondônia. 2010.

P.C.N. Parâmetros Curriculares Nacionais. Língua Estrangeira. Brasília. 1998. Ministério da Educação e do Desporto. Secretaria de Educação Fundamental. Terceiro e Quarto Ciclo do Ensino Fundamental.

SAUDERS, C, Maria; CAMPOS, R, Ticiana; MACHADO, Rachel. História do Ensino de língua no Brasil: Avanços e Retrocessos. Disponível em : http:// www.helb.org.br/index.php/revista-helb/ano-1-no-1-12007/98-historia-do-ensino-de-linguas-no-brasil-avancos-e-retrocessos Acesso em : 25/08/2017 


\section{CAPÍTULO 8. REESCRITAS DO EU MÚLTIPLO NOS DIÁ- RIOS DE ALEJANDRA PIZARNIK}

Gracielle Marques

Erlândia Ribeiro da Silva

\section{Diário: um gênero com luz própria}

Os gêneros confessionais ${ }^{1}$ ocuparam tradicionalmente um lugar secundário no campo da crítica literária. Philippe Lejeune (1996, p.85), entre outros, nas últimas décadas do século XX rebateu as ideias depreciativas de que os escritos autobiográficos eram uma espécie de rascunho amorfo de um romance, vinculadas pelos literatos, e de que se tratava de um testemunho parcial que debilitava a verdade buscada, na visão dos historiadores. Esse quadro de valores foi alterado com o desenvolvimento teórico francês e anglo-saxão sobre essas escritas, que as reposicionou dentro do ecossistema literário, destacando precisamente suas características lacunar, informe e íntima. Nos últimos anos se viu uma abundante produção teórica e crítica sobre esses gêneros e sua gênese, revigorando sua produção e recepção.

No que se refere ao diário, gênero de que nos ocuparemos neste trabalho, são importantes algumas pontuações. Trata-se de um gênero moderno, uma vez que se estabeleceu no século XIX. Desde sua origem captou a fissura entre as esferas públicas e privadas e a sensibilidade do individualismo burguês. Nessa direção, a publicação de diários adota a ressignificação do conceito de intimidade que deixa de ter um valor associado ao privado, em paralelo com a mudança paradigmática no campo da psicanálise. Contudo, ao contrário do que se possa imaginar, os diários não devem ser lidos como o acúmulo de acontecimentos íntimos de uma vida extratextual comprovada, mas sim uma elaboração textual ficcional que borra as fronteiras entre registros biográficos e ficcionais de forma a criar a ilusão de espontaneidade, sinceridade e verdade.

1 Maciel (2004, p.75-91) entende Literatura confessional o gênero literário que abarca o diário, a memória e a autobiografia. 
Outro aspecto importante se relaciona com sua grande variedade de temas e formas, além da liberdade de mistura com outros gêneros. $\mathrm{O}$ que o distingue, portanto, é a anotação fragmentada de restos e experiências vitais e literárias regida por um calendário, muitas vezes de maneira descontínua. Para Gallego Cuiñas, Estrade e Idmhand (2016, p.12), a aparição do diário muitas vezes esteve associada à morte de seu autor. Tal circunstância potencializa seu sentido testamentário e os ares de sensacionalismo ao seu redor.

Embora não exista uma diferença estrutural (ponto de vista do narrador) entre o diário de um escritor e o de qualquer outro indivíduo, para aquele este gênero lhe possibilita um espaço narrativo no qual forja sua ficção, seu estilo e seu "eu". A autorreferencialidade comparece de uma forma explícita nos diários de escritores o que provoca o interesse de muitos leitores em iluminar aspectos de seu universo poético (Gallego Cuiñas; Estrade; Idmhand, 2016, p. 10). Essa possibilidade explica, em partes, a sua forte presença no mercado editorial e sua circulação.

A prática do diário também se define por sua qualidade alusiva. Para Lejeune, (1996, p. 71) a leitura de um diário íntimo se compara a entrada em um quarto escuro, a qual exige um tempo de assimilação para os olhos. Da mesma forma, o diário demanda um tempo para que se entenda seu ambiente implícito, seus códigos e segredos até que se alcance ler nas entrelinhas. $\mathrm{Na}$ análise diacrônica de diários escritos por mulheres, Lejeune destaca que ao longo do tempo foi possível perceber a progressiva liberação dessa linguagem cifrada.

Também, como consideram alguns teóricos, a escrita de um diário é uma forma de vida, em torna da qual se constrói uma (auto)figuração diária e programada. Acrescenta-se a isso "que la mayoría de diaristas son grandes lectores de diarios, por lo que podríamos afirmar que sus autores llevan al extremo el ejercicio literario (lectura/escritura) como modo de vida" (Gallego Cuiñas; Estrade; Idmhand, 2016, p. 13).

Tendo em vista esses e outros aspectos do complexo gênero diário, este trabalho toma como objeto de análise a produção diarística da autora argentina Alejandra Pizarnik (1936-1972), a qual foi compilada por Ana Becciú sob o título de Diários (2016) e publicada postumamente. Nas mais de mil 
páginas que compõem essa edição ampliada dos Diarios a instigante narradora, apresentada como idêntica a autora, confidencia seus pensamentos, leituras e interrogações sobre os âmbitos da vida cotidiana, interpessoal e literária, sob um olhar consciente das limitações impostas ao seu sexo em uma sociedade patriarcal. A partir dos apêndices intitulados Resúmenes de varios diarios, 19621964, presentes nessa publicação, e também recorrendo a outras partes da obra, objetivamos analisar como a existência de elementos da escrita literária diarística permite ler seus diários como gênero literário híbrido, no qual vida e obra se mesclam para propor uma nova roupagem aos códigos especificamente literários, transgredindo as fronteiras entre referencialidade e ficcionalidade, característica da modernidade.

Em um desdobramento dessa análise buscamos demonstrar como a autora utilizou do recurso da escrita literária em seus diários, inventando um "eu" ficcional que contaminaria de forma enigmática a própria biografia da autora, permitindo assim que a vida da mesma fosse lida como texto a partir de uma prosa, muitas vezes, poética.

\section{Alejandra Pizarnik: um ser literário}

Mesmo depois de mais de quatro décadas da morte da poeta argentina Alejandra Pizarnik, sua obra, que começa a ser traduzida para o português, ainda é lida por sua faceta sedutora, transgressiva e excepcional. Nascida como Flora Alejandra Pizarnik no dia 29 de abril de 1936, em Avellaneda, na província de Buenos Aires, era filha de imigrantes judeus de origem russo-polaca, que fugiram do extermínio nazista. Alejandra $\mathrm{Pi}$ zarnik, nome mais conhecido pelo público, usou ao longo de sua breve vida vários nomes, como Buma, Flora, Blímele, Alejandra e Sasha. Seu falecimento ocorreu na mesma cidade em 25 de setembro de 1972.

Devido à grande dedicação pela literatura, a autora já aos dezenove anos de idade publicou seu primeiro livro, La tierra más ajena, de 1955. Para a crítica literária esse seu primeiro livro, apesar de iniciante, já indicava os caminhos pelos quais a autora seguiria em seu trabalho poético. Nesse primeiro livro a 
autora traz à tona temáticas que se repetiriam ao longo de sua carreira literária como a melancolia, o silêncio do eu e a vontade de fuga do mundo.

Em 1956, publica o poemário La última inocencia, o qual foi precedido por Las aventuras perdidas (1958), Los trabajos y las noches (1965) Árbol de Diana (1962) e Extracción de la piedra de locura (1968). Os três últimos são considerados pela crítica o ápice de sua escrita poética. O texto em prosa La condesa sangrienta (1965), a obra teatral Los poseidos entre lilas (1969) e o inclassificável La Bucanera de Pernambuco o Hilda la polígrafa (1971) pertencem a uma vertente da escrita de Pizarnik marcada por uma singularidade perturbadora, mas também pelo seu esquecimento pela crítica. Entre outras publicações póstumas, em 1998, foi publicado Correspondencia Pizarnik por Ivonne Bordelois.

Recebeu importantes prêmios, como, por exemplo, o Primer Premio Municipal de Poesía em 1965, a bolsa de estudos Guggenheim em Artes América Latina e Caribe em 1969 e a bolsa de estudos Fulbright em 1971.

Um detalhe que chama a atenção em sua biografia é que os fatos de sua vida pessoal se confundem com seu próprio fazer literário. Um dos indícios do apagamento dessa fronteira é sua obra diarística. A autora registra em vários momentos essa entrega à Literatura, como lemos nesse registro de 19 de janeiro de 1959: "No me interesa nada. Literatura. Toda yo soy un ser literario" (Pizarnik, 2016, p.262).Vida, arte, obra e corpo se fundem completamente em um duplo movimento que a pesquisadora e sua biógrafa, Cristina Piña (2012, p. 111), aponta como “[...] estetizar la vida y hacer obra con el cuerpo". Portanto, parece inevitável pensar seu projeto literário desvinculado de sua produção diarística, a qual teria iniciado ainda na adolescência.

A autora, entre os anos de 1960 e 1964, decidiu viver em Paris. Esse período foi bastante enriquecedor para Alejandra, já que nesses anos teve contato e criou laços de amizade com importantes escritores como Octavio Paz e Júlio Cortázar. Durante essa etapa parisiense, Alejandra definirá sua concepção de poesia como o lugar da liberdade absoluta, conforme relembra Cristina Piña: "La poesía es el lugar donde todo sucede. A semejanza del amor, del humor, del suicidio y de todo acto profundamente subversivo, la poesía se desentiende de lo que no es su libertad o su verdad.” (Pizarnik apud Piña, 1991, p.127) 
As subversões de valores, de cânones e de convenções que acompanham sua poesia e prosa, revestidas de humor e perversão, também convivem com a expressão de uma experiência de profunda dor e angustia interior. Dualidades e contradições de uma subjetividade diante dos embates da realidade.

Em que pese o esforço do trabalho crítico e editorial em tentar decifrar a enigmática personagem que Pizarnik criou de si mesma, fragmentada, louca, lúcida, extravagante, tímida, sua obra-vida, dispersa em uma variedade de gêneros literários híbridos, ainda não publicada em sua totalidade, continua encerrando muitas interrogações ao passo que segue magnetizando seus leitores.

\section{Diário de escritora e leitora}

Segundo Becciú (2016), a totalidade dos diários abarca três etapas distintas de elaboração desses textos, cuja narrativa se refere ao relato de seu cotidiano e suas vivências subjetivas, especialmente do período em que esteve em Paris. $\mathrm{O}$ primeiro grupo de textos está composto pelos cadernos que registram os dias corridos do período de 1955 a 1971. Com mais de novecentas páginas, é o que Becciú considera o texto prévio, isto é, que serviu posteriormente para o trabalho de cópia e reescrita de Pizarnik. O segundo, nomeado por Becciú de Resúmenes de varios diarios 1962-1964, aparece como seis apêndices na edição ampliada de 2016 e apresenta a reescrita dos cadernos desses anos realizada, maiormente, em sua chegada a Buenos Aires, em março de 1964. A terceira reunião de textos trata dos documentos datilografados e com correções manuscritas da autora que foram pensados para serem publicados por Pizarnik, os quais Ana Becciú (2016, p. 11) considera como a fase final desse processo de reescrita dos diários.

Em sua correspondência, aparece a referência a um diário anterior a 1954 e um caderno desaparecido de 1960, que podem ter sido destruídos pela autora conforme algumas menções que ela teria realizado. Esse dado é relevante, pois atesta que sua produção diarística é anterior a sua mais conhecida habilidade como poeta.

A compilação, edição e publicação dos diários, no entanto, provocaram algumas reflexões teórico-críticas envolvendo a composição diarística. Entre outros aspectos, os questionamentos da crítica especializada ao trabalho de Becciú 
se dirigiram para a dialética privado-público. Por um lado, Patricia Venti (2004) sustenta que a afirmação de que Pizarnik teria expressado o desejo de publicá-los sob a forma de "diário de escritora" (Becciú, 2016) pode ser desmentida nas hesitações que a autora registra em algumas entradas de seus diários. Piña (2012, p.150), por sua vez, releva esse aspecto ao admitir que o caráter ficcional de uma obra se constrói para além das intenções de uso seu autor, podendo ser outorgado ao conjunto de seus receptores, ou seja, no ato da leitura.

Por outro lado, Piña e Venti enfatizam outro motivo ponto dessa dialética que incidem na edição dos textos privados de Pizarnik, isto é, o da supressão, sobretudo nos seus diários, das passagens relacionadas com sua vida amorosa, dos nomes de pessoas vivas e ofensas a pessoas conhecidas. Outros questionamentos sobre o ocultamento dos critérios de seleção usados por seus editores também são levantados. No entanto, na nossa visão, essas reprovações parecem dizer mais respeito ao controle que se quer exercer sobre o sistema literário, com base em um pensamento conservador de fidelidade e originalidade da criação literária, o qual não valoriza a manipulação dos diários operada pela edição póstuma entendida como reescrita (Lefevere, 2007, p. 24). Com isso, os Diários (2016) se mostram como um espaço textual que acompanha a própria complexidade do gênero, propício à descontinuidade, ao reverso e à desconstrução.

O mérito da compilação de Becciú, na nossa visão, é mostrar o longo processo de leitura, escrita e reescrita de Pizarnik. Com relação à hipotética traição ao uso pessoal dado pela autora, concordamos com Sheila Dias Maciel (2004, p. 86) de que no momento da publicação, póstuma ou não, de diários se "coloca em xeque seu caráter de 'segredo", pois as modificações e recortes que sofrem os "transformam numa espécie de ficção em que o caráter de texto espontâneo é calculado”. Esse procedimento é operado não apenas por Becciú como pela própria diarista, quando destaca e reescreve algumas de suas partes para publicação. Ao caracterizar seus cadernos como "diário de escritora", a autora nos mostra outro valor para esses diários, que deixam de ter apenas interesse privado.

O importante crítico literário argentino Alberto Giordano (2016, p. 210), autor de $A$ senha dos solitários: diários de escritores, ao se deparar com tal denominação do "diário de escritor" define: 
Por diário de escritor entendo, quando salto da evidência empírica à arrogância conceitual, um diário que, sem renunciar ao registro do privado ou do íntimo, expõe o encontro entre notação e vida desde uma perspectiva literária, e, desde essa perspectiva interroga-se sobre o valor e a eficácia do hábito (disciplina, paixão, mania?) de anotar a cada jornada.

Com tal reflexão, observamos que o diário de escritor estaria tanto para ajudar o autor, enquanto ser que vive, age e sofre, e precisa expurgar seus sentimentos em algum lugar - nesse caso no diário -, quanto para desenvolver e refletir sobre o processo de escrita, embaralhando os limites do real e do imaginário. Para Pizarnik não foi diferente. A prática do diário lhe permitiu a minuciosa sensibilidade da escrita dos afetos em seus relatos cotidianos, mas sempre no limite entre fato e artefato (Maciel, 2004, p. 87). Compreende dessa forma o que Maurice Blanchot (2005, p. 274) chama de uma "empresa de salvação", ou seja, escrever para salvar a vida e "elevar a vida nula à bela surpresa da arte". Concomitantemente, Pizarnik ensaia com a escrita dos diários uma forma de narrar um texto em prosa, como podemos ler em junho de 1955:

Pensar en la novela, o en las cartas a Andrea. Convencerse de la importancia secundaria del argumento. Lo esencial son los trozos de caracteres. Tiemblo por mi subjetividad. Desconfío de mi constancia. ¿Cómo podría lograr llegar hasta el fin? Pienso que actualmente todo argumento sería autobiográfico. No tengo el menor deseo de crear seres felices, ni países que no he visto ni situaciones en que no intervine. [...] Me gustaría una novela autobiográfica, pero escrita en tercera persona. Por supuesto que comenzaría en mis diecisiete años (Pizarnik, 2016, p. 41).

Suas reelaborações do diário giraram em torno a esse desejo de trabalhar a matéria factual íntima em uma forma literária que melhor resolvesse suas incertezas sobre o sujeito da enunciação. Pizarnik realiza várias cogitações em torno a esse texto em prosa que nunca veio a público. As informações biográficas e a exposição do "eu", que poderiam assumir os contornos de um romance epistolar ou autobiográfico, ficariam dissimuladas, no primeiro caso, pela presença de um destinatário explícito (Andrea), embora isso afetasse a espontaneidade do "eu". 
Por isso, no segundo caso, planeja um narrador na terceira pessoa, o que, por sua vez, adquire uma rigidez que não permite falar de si mesmo.

Diante desses impasses, fica evidente a temática metaficcional dos diários, ou seja, Pizarnik está sempre às voltas com as questões sobre a construção da linguagem literária, sobre sua incapacidade de realizar o texto em prosa: "También me considero incapaz de escribir en prosa. Pero decirlo es también prosa, decir de mi incapacidad también es escribir" (Pizarnik, 2016, p. 419). O avesso dessa afirmação desvela a anteposição da escrita diarística, gênero que lhe permite todas as ondulações entre o sujeito e o objeto da narração.

Com todos esses fatores que moldavam o processo de escrita da autora, eles acabaram também por direcionar um caminho de intenção para o seu texto. Nesse sentido, assim como nos diz Umberto Eco (2012, p. 29) em Interpretação e Superinterpretação:

Entre a intenção do autor (muito difícil de descobrir e frequentemente irrelevante para a interpretação de um texto) e a intenção do intérprete que simplesmente 'desbasta o texto até chegar a uma forma que sirva a seu propósito' existe uma terceira possibilidade. Existe a intenção do texto.

Assim, a intenção dos textos da autora nos chama essencialmente à reflexão de tudo o que rodeia as obras literárias, não somente com questionamentos para os escritores, mas também para os leitores. As indagações do porque se escreve, do porque se lê, do porque existe esse interesse e necessidade vitais de leitura e escrita, que acabamos por responder e verificar no texto de Pizarnik, estão na base de sua própria construção.

Ademais das cavilações sobre o próprio processo da escrita presentes nos diários, não podemos nos esquecer de que Alejandra, antes de escritora, foi uma leitora assídua. Essa atividade durante diversos momentos de seu diário é comentada pela escritora. Algumas leituras marcam sua adolescência, conforme a autora avalia: "Pero creo que me colmé de demasiada literatura angustiosa. (Recordar lo maravillada que quedó la adolescente que fui cuando Rilke, Dostoievski, Rimbaud y tantos otros que hablaron con fervor del sufrimiento.)"(Pizarnik, 2016, p. 477). 
Outras figuras importantes são descritas pela autora como, por exemplo, a escritora francesa Marguerite Duras, conhecida por seus romances e por ter escrito o roteiro do filme Hiroshima, mon amour (1959) do diretor francês Alain Resnais. Assim, no dia 25 de agosto de 1962, Alejandra comenta ter almoçado com Marguerite e com B. (figura identificada apenas com as iniciais) e que a B. "no le gustan los libros de Marguerite 'Ils sont trops innocents' dije sin agregar 'pour toi". Após esse relato Alejandra, não comenta mais a respeito, porém vê-se que a autora fez questão de descrever em seu diário a opinião de B. sobre a escrita de Marguerite, que talvez coincida com a sua própria. Mais uma vez, podemos reforçar a ideia de que a literatura não é só mais uma simples parte integrante de sua vida, mas sim que é parte indissociável, inseparável.

Em outro trecho do diário, registrado em 23 de setembro de 1962, o diálogo com a tradição literária, explicitado pela autora, sugere a sua identificação com um personagem literário que vivencia a mesma inadequação social e lhe "ajuda" a seguir determinada em sua trajetória como escritora: “[...] Nadie oye mi silencio. Sólo yo oigo al silencio. Releo a Cervantes. Sólo don Quijote me ayuda" (PIZARNIK, 2016, p. 1009).

Essa releitura de Dom Quixote da qual Alejandra nos fala e a ajuda por ela recebida são fatos bastante interessantes para refletirmos, já que a figura emblemática do cavaleiro errante é marcada por características tais como a inocência, o sonho, a imaginação, a crença do personagem na ficção como meio de transformar a realidade. E, quando pensamos nos trechos dos diários de Alejandra, também encontramos tais características, um exemplo claro está no fragmento a seguir:

24 de febrero, domingo [1963]. Las palabras son cosas y las cosas palabras. Como no puedo otorgar realidad a las cosas las nombro y creo en sus nombres [el nombre se vuelve real y la cosa nombrada es la fantasma del nombre]. Ahora sé por qué escribo los poemas que escribo que son inmóviles y estáticos como cosas. Es mi sueño de un materialismo dentro del sueño (Pizarnik, 2016, p. 1023).

Nesse excerto, é possível reconhecer em Alejandra as características descritas anteriormente que apontam a literatura como a transformação da realida- 
de; a última frase desse trecho revela que o seu sonho é o de construir um materialismo dentro do sonho. Essa é exatamente a ideia da realidade transformada ou de seu veemente desejo de substitui-la pela literatura. Em uma entrada de 31 de março de 1963 dos Resúmenes... Alejandra escreve "Soñé con Alicia, con los espejos, con el Rey y la Reina...” (Pizarnik, 2016, p.1025), a representação de Alice no país das maravilhas também nos conecta com a escrita da autora do ponto de vista da ficção em detrimento da realidade, no eterno jogo de transformar o material real em escrita, em metáfora, em ficção, em literatura.

A autora também nos revela ser uma leitora de diários, entre os quais menciona os de Franz Kafka, Virginia Woolf, Katherine Mansfield, Cesare Pavese, Charles du Bois, Julien Green, André Gide. Cita a dificuldade de explicar a poesia de Góngora, dizendo que é tão difícil quanto explicar um perfume. Relê Crime e Castigo de Fiódor Dostoievski e se sente mal a ponto de sofrer com essa leitura devido à paixão que o autor coloca em todos os detalhes, deixando-a verdadeiramente doente. Em outros momentos, faz referência a Freud, Shakespeare, Artaud e seus amigos escritores Octavio Paz, e Julio Cortázar, com quem mantinha um contato frequente. Todos esses autores e outros mais que a autora cita durante o passar dos dias de seu diário são extremamente importantes para o que a escritora viria a escrever mais tarde ou o que estava a escrever simultaneamente as suas leituras.

Outro ponto crucial para entendermos a construção de sua voz na escrita diarística se deve à condição histórica da mulher escritora. Dentro do gênero confessional, a voz feminina parece muitas vezes ganhar o seu espaço, tratando-se de diários literários ainda mais. Podemos pensar que isso acontece porque a voz feminina, de modo geral, sempre foi silenciada dentro de nossa sociedade, não sobrando espaço para que na vida cotidiana essa voz fosse escutada ou levada em consideração e dentro da literatura não seria diferente, esse espaço de voz também era diminuído. É nesse sentimento sufocante de não poder dizer claramente o que se sente em alto e bom som que nascem os diários femininos, no sentido de expurgar o que se sente para fora, nesse caso, para suas páginas.

Nesse sentido, Alejandra Pizarnik ao escrever poesias e paralelamente escrever um diário, ao qual denominava como "diário de escritora" efetuou al- 
gumas transgressões às normas dessa produção literária feminina tradicional. Podemos dividir em dois elementos cruciais para que a escrita de Alejandra seja compreendida nesse sentido.

Em primeiro lugar, podemos destacar os novos caminhos que sua escrita abre dentro do âmbito da literatura feita por mulheres. Em diversos momentos ao ler os diários da autora perdemos de vista o ano em que estamos, já que os questionamentos e a visão de mundo abordadas no texto nos reportam para adiante do tempo histórico de Alejandra. Em segundo lugar, é preciso destacar o quanto esse texto diarístico não recai em um lirismo de prosa poética comum às primeiras poetas, que inscreveram seus nomes através da estética do que é belo, puro e delicadamente feminino. Alejandra traz à tona um feminino mais violento em seus escritos, mais consciente do peso das ordens estabelecidas pela sociedade patriarcal em que vivia.

Dessa forma, Alejandra Pizarnik distorce totalmente a prática poética do que se tinha por uma "literatura feminina", as noções que a autora aborda em seus escritos traduzem um pensamento muito à frente de sua época. Cristina Piña (2012, p. 28) é enfática ao apontar que:

[...] nunca hubo textos obscenos firmados por mujeres hasta la aparición de las obras de Pizarnik. Y si lo obsceno es difícil de aceptar en general, por traer a la escena lo desde siempre oculto, resulta más revulsivo aún, dentro de una sociedad que ha restringido tan significativamente las posibilidades expresivas y vitales de la mujer, cuando es una escritora quien se atreve a articularlo.

Assim, já podemos verificar a importância da voz da autora para romper com uma imagem imaculada da literatura escrita por mulheres. Em outro excerto do diário, Pizarnik (2016, p.1023) deixa claro sua obstina busca:

Las palabras son mi ausencia, en mí hay una ausencia hecha de lenguaje. No comprendo el lenguaje y es lo único que tengo. Este "silencio" de las palabras, de las que digo y escribo, es el horror, el vértigo. Pero ninguna presencia humana se me presenta como evidencia. Amigos y amantes; cuerpos vacíos e indiferenciados. Sólo hay fantasmas que he amado hasta pulverizar mi conciencia. 
Nesse trecho, a reflexão sobre a tarefa interminável e insuficiente da obra pela escritora que independe da verdade do mundo e seu apagamento no silêncio que a escrita lhe convida (BLANCHOT, 1987, p.17) distanciam seus escritos de outras prosas femininas. Isso acontece porque a autora escrevia sem que o regime padronizado dessa escrita a guiasse, pois perseguia uma forma própria de enxergar e escrever o mundo e seus sentimentos. A ideia de amor, por sua vez, também se afasta daquela representada tradicionalmente na escrita de mulheres. Pizarnik aposta na sua própria vivência e não torna isso mais ameno, pelo contrário, utiliza de uma acidez e tom de tristeza que são seus. Não existe aqui uma aposta em uma prosa de enfeites, que conta o trágico com a esperança de que tudo se renove e venha melhorado, há uma consciência limpa do vazio e da incerteza.

Aqui verificamos mais uma vez a intensidade e maestria do texto da autora, que nos leva aos seus escritos mais íntimos nos mostrando parte de um pensamento que nos possibilita captar as fissuras de sua subjetividade, marcada pelas mesmas angústias de todos os indivíduos. Esse sentido íntimo está estritamente impresso nas origens do diário e sua relação com o feminino:

Desde este punto de vista, desde el significado múltiple de lo íntimo, el modelo de recogerse en la intimidad para escribir un diario no implica la búsqueda de placidez, sino, al contrario, un encierro contradictorio, angustioso y amenazante, aunque ya no religioso, y, como tal, análogo de actitudes y costumbres femeninas en paralelo histórico. (CATELLI, 1996, p.92)

Assim, a partir dessa compreensão dos diários como escrita ficcional e não meramente notas datadas sobre a vida analisaremos a elaboração do "eu" dos diários, em especial nos Resúmenes..., focalizando alguns de seus momentos de oscilações entre a emergência do outro, a poeta e o afloramento de sua subjetividade. Esse recorte nos permitirá ainda vislumbrar o trabalho eminentemente racional e lapidar da linguagem, que provoca através dos cortes cirúrgicos a intensidade e a tensão estilística. 


\section{Reescrever-se: desdobramentos do eu}

Os Resúmenes de varios diarios 1962-1964, conforme já mencionado, são um recorte feito pela autora Alejandra Pizarnik dos seus diários originais escritos nesse mesmo período. Assim, durante a publicação das três fases da escrita nos permite ler os resumos e cotejar com o texto prévio e verificar na tarefa de reescrita da Pizarnik outros sentidos da versão lapidada pela autora. Esse exercício de comparação dos escritos originais e depois do recorte feito pela autora nos coloca frente a frente às preocupações da escritora em neutralizar o "eu", ter uma linguagem mais objetiva dentro do subjetivismo e exteriorizar-se.

Dessa forma, apresentaremos um excerto do diário da autora que evidencia o quanto seu projeto literário diarístico foi pensado, reelaborado e reescrito. No texto prévio, o dia 31 de maio de 1962 seria assim marcado pela autora:

31 de mayo.

Las dunas, el mar, las gaviotas. Un cuerpo desnudo dejándose por las alas, loco de desposesión.

Aún entonces te buscaba. Miríadas de ojos barridos por el viento que los hinca en las arenas y en las cabezas de los peces. Morir era lo de menos. Hubiera querido estar preparada para tu venida, tener el tiempo de disfrazarme de lo que más amabas: un pequeño trovador de ojos verdes qui joue le luth. Aunque te esperaba no te esperé. Era como si me esperara a mí. Pero yo no llegué. Ni tu tampoco.

En el medio de la noche, camino hacia el frío, el viento, lo desconocido. La playa sola ruge, deshaciéndome. A veces, desnuda, montaba un caballo negro y avanzaba por las orillas. Entre mis piernas sentía el roce de seda del animal. Y era como entrar de tu mano en una casa de rosas.

Yo no digo que vengas, que estés ya aquí, que has venido. Pero me niego a negar la espera de tu venida. Déjame esperarte. He nacido para esto. Déjame delirarme sin ti, asistir a la deformación de mis huesos que sólo aman una sombra. He caído en la trampa de esta espera y sin duda soy feliz.

Que has venido. Que tu presencia estremece el cálido color de las hojas muertas. Milagros de la que espera y ve y siente. Y yo te seguiría bajo cualquier forma, como polvo o humo o viento. Entraría por tu respiración, por 
tu sonrisa, por tus tristes deseos de evadirte hacia donde no haya lenguaje sino solamente ojos devorándose, ojos amándose en el peligro de una desnudez absoluta.

La que miraba el mar en noches viejas. Recuerdos de infancia: muros, detonaciones, gritos. El aire es un campo de concentración para una niña minúscula que baila sobre el filo de un cuchillo. Las risas ajenas son un obstáculo. Los veranos también. Queda como solución rodar por las escaleras de mármol hasta que el dolor de los huesos obligue a reconocer la realidad de los fenómenos físicos.

Y tú me viste llegar, mendiga hedionda enamorada de su sombrero con flores y plumas. Había un color lila que humeaba y yo estaba de verde dentro de mis harapos. Dancé para que te rieras. Me pinté las uñas de azul. Toqué la guitarra y canté canciones que hablan de pequeños instantes únicos en los que el dolor se aduerme y hay sólo deseos de amar (Pizarnik, 2016, p. 412-413, grifo da autora).

Esse fragmento explora, em prosa poética, o desejo de encontro do "eu" com um "tu", de uma promessa de entrega e desapego que ignora a própria morte. O "tú" do texto prévio, de certo modo, aponta para um desdobramento do "eu" ("Era como si me esperara a mí"), o que olha e é olhado, muitas vezes utilizado como recurso em um monólogo interior nos diários de Pizarnik (Rocco, 2016, p. 204).

Pizarnik cria uma imagem multissensorial que impõe uma maneira de ver que é toque (Blachot, 1987, p. 22). O contato com essa visão não pertence ao mundo referencial, mas a um meio absoluto anterior a palavra, cuja profundidade ilimitada se desintegra em imagens (Blanchot, 1987, p. 23). Um meio de fascinação determinado por um "tu" com o qual o "eu" deseja fundir-se até converter-se apenas em olhos; “o nosso próprio olhar no espelho" (Blanchot, 1987, p. 23), que atrai, que é luz, mas também abismo. Esse momento de fascinação é atravessado pela lacerante recordação de um campo de concentração, em referência a perseguição e extermínios sofridos pelos seus familiares, na qual se destaca a paradoxal figura de uma minúscula menina dançando no fio da navalha. A condição do "eu” constituída de precariedade (despossuída, 
desnuda, mendiga) e situada na tênue linha entre a vida e a morte traz consigo apenas o canto (o trovar) para seguir recordando as dores de sua história pessoal e familiar e desejando.

Essa entrada, na qual a escritora se autoriza enquanto sujeito de sua história, de suas dores e afetos, é reduzida na reescrita efetuada em 1964, quando regresse a Buenos Aires, à frase final: "31 de mayo. Cantó canciones que hablan de pequeños instantes en los que el dolor se duerme y hay deseos de amar" (Pizarnik, 2016, p. 993, grifo da autora).

As duas linhas, no entanto, condensam toda a significação expressa anteriormente, além de significar em outro nível interpretativo a própria estrutura fragmentária dos diários (pequenos instantes), nos quais tematiza sobre a dor, o desejo e o amor. Nesse fragmento, aparece uma mudança discursiva relacionada com o sujeito da enunciação. No texto prévio, a ação aparece expressa na primeira pessoa, "cante”", porém nos Resúmenes... a mesma ação é transferida para um sujeito na terceira pessoa. O "eu" se transforma em "outro". A alteridade se apresenta de forma a marcar uma distância com o "eu", ver-se de fora: "Ele' sou eu convertido em ninguém, outrem que se torna o outro, é que no lugar onde estou, não posso mais dirigir-me a mim e que aquele que se me dirige não diga 'Eu', não seja ele mesmo. (Blanchot, 1987, p.19). Um jogo de máscaras que converte o "eu" em múltiplas personagens potencializadas na reescrita. É também aquele intento, conforme comentamos anteriormente, de ocultar a coincidência de identidade entre autor, narrador e personagem.

Pizarnik se revela a cada momento múltipla e consciente das incertezas que a rodeia. Suas precariedades eclodem sob a forma concisa e intensa que podem representar esse dia 31 de maio de 1962, mas, sobretudo, seu próprio fazer literário, seu canto revelado nos fragmentos da escrita cotidiana. $\mathrm{O}$ canto forma imagens que a autora explica em outro trecho de seu diário:

Ahora sé que todo me importa y quiero reventar y quemarme y estallar. Porque esto no es la vida. Y esto no es la poesía. Y quiero cantar y no hay qué cantar, a quién cantar. Sólo hay mierda y a la mierda se la insulta. Pero yo quisiera cantar (Pizarnik, 2016, p. 361-362). 
Esse canto é a própria poesia. O desejo de cantar e não conseguir fazê-lo é a imagem relacionada ao silêncio que Alejandra traz em outros escritos, muito analisados em trabalhos que abordam a escrita da autora. A dicotomia entre o canto e o silêncio são divisões relacionadas à própria figura do escritor que passa por períodos de silêncio ao não criar, como sugerido nesse trecho do diário citado acima. Silêncios que Pizarnik impõe a sua escrita, quando pensa em publicar seus diários que falam muito da situação política na Argentina que ela teve que vivenciar.

Deste modo, as oscilações do "eu" implica a relação híbrida entre ficção e verdade do texto diarístico. A própria escritora, ao refletir sobre esses "yos" da enunciação, nos deixa algumas pistas: "El yo de mi diario no es, necesariamente, la persona ávida por sincerarse que lo escribe" (Pizarnik, 2016, p. 997). Desse modo, é possível verificar a distância entre o eu que escreve e o eu que se inscreve nas páginas do diário de escritora, porque apesar de muitos fatos relatados serem reais e vividos pela autora, não podemos esquecer também que parte dessa escrita serve como processo para ela de escrita e reescrita de textos, passando assim por modificações, como um laboratório literário, alterando a realidade e transformando em outra coisa, nesse caso, transformando em literatura.

A linha tênue entre esses "eus" que configuram o texto de Alejandra Pizarnik nos permitem ter uma nova visão sobre os demais relatos de seu diário. A primeira leitura que um leitor ansioso por conhecer um pouco mais da vida da autora cairia, resvalaria certamente na superficialidade do texto se o mesmo não se atentasse as pistas deixadas pela autora, dessa maneira esse leitor tomaria o autor como "real" e o diário como "verdade". Porém, com a informação de distância entre o sujeito enunciador e o sujeito enunciado que Alejandra nos deixa os relatos passam a habitar outro patamar de interpretação, sem que a adjetivação de relato apenas íntimo tome corpo desse texto. Em outras palavras, a experiência vital é substituída pela experiência da escrita e da leitura (Gallego Cuiñas; Estrade; Idmhand, 2016, p.14).

A autora em outro trecho de seu diário nos relata uma indagação: "Pregunto si la poesía es tan trágica y terrible como yo suelo decirlo. Después de todo, los pocos versos válidos que escribí se escribieron solos" ( $\mathrm{Pi}$ zarnik, 2016, p. 1015). Nesse excerto, a indagação que a autora faz é calcada 
no seu "eu" que costuma transformar a poesia em algo trágico e terrível, e a mesma traz dúvida quanto a essa afirmação, assim um de seus "eus" - provavelmente o enunciador - é mais consciente e objetivo do que o outro sujeito do enunciado - logo esse exemplo sobre a caracterização da poesia serve também como base interpretativa para a leitura do diário da autora, já que os acontecimentos podem não ser tão trágicos assim, mas foram construídos certamente sobre a ótica literária da tragicidade.

A manutenção da ilusão referencial é construída por uma atmosfera atraente e encantadora que provoca no leitor a sensação de que estamos muito próximos do seu "eu" mais íntimo. Ao refletirmos sobre esse aspecto do texto de Pizarnik (2016, p. 1016) nos deparamos com a seguinte reflexão da autora:

Nociones ajenas: Dios - la unidad - el ritmo universal...

Las entrañables: yo - mundo, yo - otros, yo - muerte

que se pueden reducir a

yo - yo

Nesse caso, o "eu" dialoga com o mundo, com os outros e com a morte, podendo ser reduzidos a dois "eus". Esses dois “eus" assumiriam, conforme nossa interpretação inicial, a posição de quem sente e de quem inscreve e constrói essas emoções, respectivamente, típica do ofício do poeta fingidor pessoniano.

Assim, o ato de escrever da poeta e diarista se inscreve em um horizonte humanizador a partir do momento em que suas escritas permitem ao leitor vivenciar dialeticamente os entraves de nossa decisiva relação com o outro.

\section{Considerações finais}

A (re)escrita diarística de Alejandra Pizarnik em Resúmenes de varios diarios 1962-1964, nos possibilitou ver nesse gênero a construção de um "eu" ficcional que se desdobra em muitos, transgredindo as concepções de verdade, unidade e do próprio gênero (textual e sexual). Em outros termos, a narrativa diarística de Pizarnik lança mão de experiências vividas e imaginadas e alcança, através da intensa e obsessiva reelaboração de seus escritos, um potente olhar de dentro e de fora de um personagem, um eu literário, conforme tentamos demonstrar. 
Investigamos também a motivação da autora em chamar seus diários como "diários de escritora" e notamos sua consciência de suplantar o registro pessoal. Mesmo que Alejandra dialogue com informações biográficas (matéria que o escritor sempre manipula) sua escrita sempre está no patamar da ficção, pois é ali que ela sobrevive. Assim, chegamos à conclusão de que a maneira como a autora escreve transforma o relato cotidiano em texto literário, fazendo com que essa escrita seja marcada por uma hibridez, onde o real e o fictício se encontram.

Nesse sentido, as reescritas dos diários feitos pela autora indicam sua preocupação com o trabalho da escrita, da linguagem e de melhoramentos do texto literário. Esse tecer de palavras cria um resultado bastante interessante, pois remonta ideias antes já tidas e as trabalha sobre uma nova perspectiva de amadurecimento. Por esse motivo, algumas vezes há alteração de sentido entre o texto prévio e o reescrito, como reinvenção e multiplicação de si. Desse modo, esse trabalho de reescrita da autora fez com que os diários ganhassem uma nova roupagem. Ainda verificamos também as referências de leituras realizadas por Alejandra que marcaram seu desenvolvimento como escritora.

Por fim, Pizarnik também questionou através da sua obra diarística paradigmas literários e da representação de gênero e da sexualidade, superando a fase feminina, caracterizada pela "imitação e internalização dos valores e padrões vigentes” (Zolin, 2003, p.256). Em seus diários é latente a resistência da autora em se manter um ser pensante e crítico, que apesar dos pesares, não abriria mão da literatura mesmo que a sociedade lhe impusesse, por meio dos papéis do gênero feminino, outras obrigações e direções a seguir. A escritora, no cenário literário latino-americano da primeira metade do século XX, no qual despontavam algumas artistas mulheres, teve que enfrentar muitas barreiras advindas da ideologia patriarcal, contudo faz prevalecer seu desejo obstinado de (re)criação.

\section{Referências}

BARTHES, Roland. Roland Barthes por Roland Barthes. Tradução Leyla Perrone-Moisés. São Paulo: Estação Liberdade, 2003.

BLANCHOT, Maurice. O livro por vir. Tradução Leyla Perrone-Moisés. São Paulo: Martins Fontes, 2005. 
BLANCHOT, Maurice. O espaço literário. Tradução Álvaro Cabral. Rio de Janeiro: Rocco, 1987.

CANDIDO, Antonio. Vários escritos. 3. ed. revista e ampliada. São Paulo: Duas Cidades, 1995.

CATELLI, Nora. El diario íntimo: una posición femenina. In: Revista de Occidente. Madrid: Fundación José Ortegas e Gasset, n. 182-183, jul./ag. 1996. p.87-98.

ECO, Umberto. Interpretação e superinterpretação. Tradução MF; revisão da tradução e texto final Monica Stahel. São Paulo: Editora WMF Martins Fontes, 2012.

GALLEGO CUIÑAS, Ana; ESTRADE, Christian; IDMHAND, Fatiha. Diarios latinoamericanos: teorías del género. In: GALLEGO CUIÑAS, Ana; ESTRADE, Christian; IDMHAND, Fatiha (Orgs.). Diarios latinoamericanos del siglo XX. Bruxelas: Editora Peter Lang, 2016. p.9-18.

GIORDANO, Alberto. A senha dos solitários: diários de escritores. Tradução Rafael Gutiérrez. Rio de Janeiro: Papéis Selvagens, 2016.

LEFEVERE, André. Tradução, reescrita e manipulação da fama literária. Trad. Claudia Matos Seligmann. Bauru, SP: Edusc, 2007.

LEJEUNE, Philippe. La práctica del diario personal: una investigación (19861996). In: Revista de Occidente. Madrid: Fundación José Ortegas e Gasset, n. 182-183, jul./ag. 1996. p.55-75

MACIEL, Sheila Dias. A literatura e os gêneros confessionais. In: BELON, Antônio R.; MACIEL, Sheila Dias (Orgs.). Em diálogo: estudos literários e linguísticos. Campo Grande: Ed. UFMS, 2004.

PIÑA, Cristina. Alejandra Pizarnik: una biografía. Buenos Aires, 1991. 
PIÑA, Cristina. Límites, diálogos, confrontaciones: leer a Alejandra Pizarnik. Buenos Aires: Corregidor, 2012.

PIZARNIK, Alejandra. Diarios. Nueva edición de Ana Becciú. 3. ed. Barcelona: Lumen, 2016.

ROCCO, Federica. Los Diarios de Alejandra Pizarnik. El loco afán por (re)escribir(se). In: GALLEGO CUIÑAS, Ana; ESTRADE, Christian; IDMHAND, Fatiha (Orgs.). Diarios latinoamericanos del siglo XX. Bruxelas: Editora Peter Lang, 2016. p.199-2010.

VENTI, Patricia. Los diarios de Alejandra: censura y traición. In: Espectáculo, no26 Universidad Complutense de Madrid, (UCM), 2004. Disponível em: <https://webs.ucm.es/info/especulo/numero26/diariosp.html/>. Acesso em: 15 abr. 2018.

ZOLIN, Lúcia Osana. Literatura de autoria feminina. In: BONNICI, Thomas; ZOLIN, Lúcia Osana (Org). Teoria literária: abordagens históricas e tendências contemporâneas. Maringá: Eduem, 2003. 


\section{CAPÍTULO 9. ANALISIS Y CONSIDERACIONES DE UNA DE LAS PONENCIAS DEL EVENTO CHARLAS SIN FRONTERAS - LIVE 2: "DIFICULTADES Y PROPUESTAS METODOLOGICAS: REFLEXIONES ACERCA DE LA EN- SEÑANZA DEL ESPAÑOL COMO LENGUA EXTRANJE- RA PARA BRASILEÑOS"}

Mariela Magali Román Gutiérrez

\section{INTRODUCCIÓN}

En el mes de junio del año 2020 tuve el agrado de recibir la invitación para ser una de las ponentes en el evento Charlas sin Fronteras - Live 2: "Dificultades y Propuestas Metodológicas: Reflexiones acerca de la Enseñanza de ELE para brasileños” en la modalidad on line vía Google meet evento vinculado al Proyecto de Extensión Charlas sin Fronteras promovido por el Departamento de Lenguas Extranjeras de la Universidad Federal de Rondônia, Campus Porto Velho. Yo soy profesora de idiomas, soy de Cusco-Perú, mi idioma nativo es el español. Enseño español e inglés. He enseñado español a extranjeros durante 14 años y durante mi formación y mi experiencia en la enseñanza de idiomas he podido conocer y entender bastante acerca de los enfoques en la enseñanza de lenguas extranjeras, las diferentes formas en las que aprenden los estudiantes, diferentes metodologías de enseñanza, y otros aspectos que forman parte de la enseñanza de idiomas. La charla se llevó a cabo el día 16 de junio del 2020, en la que expuse sobre mis conocimientos y experiencias en la enseñanza del idioma español a extranjeros especialmente a brasileños. Fue una experiencia muy linda y enriquecedora poder brindar esta charla para los estudiantes y profesores de la Universidad de Rondônia y el público interesado en la enseñanza del idioma español. Elton Emanuel Brito Cavalcanto, que fue la persona que me invitó para la ponencia, es profesor en el Departamento de Lenguas Extranjeras en la Universidad de Rondônia y fue 
mi estudiante de español en la escuela de español para extranjeros Wiracocha en Cusco-Perú durante 2 semanas en enero del año 2019. Cuando recibí su invitación para la charla me explicó que estaban haciendo este proyecto llamado "Charlas sin Fronteras" como una extensión del programa de Español de la Universidad de Rondônia ya que en este contexto de pandemia querían seguir en contacto con sus estudiantes y la comunidad interesada en la enseñanza del idioma español y habían propuesto y puesto en marcha este programa de extensión para invitar a profesores de idiomas de diferentes partes del mundo para hablar sobre diferentes puntos referentes a la enseñanza del idioma español, en este artículo tocaré los puntos más importantes de mi charla y mi experiencia como profesora de idiomas y profesora de español para extranjeros especialmente para brasileños.

\section{EL IDIOMA ESPAÑOL EN EL MUNDO}

El idioma español es un idioma muy extendido en el mundo y está siendo cada vez más hablado y estudiado por personas de diferentes países, aquí algunos datos:

El idioma español es actualmente el tercer idioma más hablado del mundo, es hablado en 21 países como idioma oficial (19 países en Hispanoamérica, además de España y Guinea Ecuatorial).Es la segunda lengua del mundo por el número de hablantes nativos, es decir lengua materna tras el chino mandarín y la cuarta lengua en hablantes tras el chino mandarín, inglés e hindi con 463 millones de hablantes nativos aproximadamente y lo hablan como primera y segunda lengua con dominio nativo 489 millones de personas alcanzando los 586 millones si se incluyen los hablantes con competencia limitada. De modo que puede ser considerada la tercera lengua del mundo por el total de habitantes tras el mandarín y el inglés con cerca de 23 millones de estudiantes y la tercera en comunicación internacional tras el inglés y el francés. El español posee la tercera población alfabetizada del mundo (un 5,47 \% del total) siendo la tercera lengua más utilizada para la producción de información en los medios de comunicación y también la tercera lengua con más usuarios de internet después del chino y el inglés 
con 256 millones de usuarios aproximadamente, lo que representa el 7,6 \% del total" ("Idioma Español”Wikipedia)

Además:

El español es la segunda lengua más importante en el ámbito internacional. El idioma español es el tercero más usado en la Organización de las Naciones Unidas y el cuarto en la Unión Europea. El español es la lengua más utilizada en los organismos de integración americana e iberoamericana ("E1 Español una Lengua Viva”- Informe 2020, Instituto Cervantes).

En el cuadro $\mathrm{N}^{\circ} 1$ podemos apreciar los 21 países donde el español es idioma oficial (19 países en Hispanoamérica, además de España y Guinea Ecuatorial) con sus datos de población, hablantes nativos en porcentaje, grupo de dominio nativo, y hablantes con competencia limitada; por país:

\begin{tabular}{|l|c|c|c|c|}
\hline \multicolumn{5}{|c}{} \\
\multicolumn{1}{|c|}{ Población de los países hispanohablantes } \\
\hline & Población & $\begin{array}{c}\text { Hablantes } \\
\text { nativos } \\
(\%)\end{array}$ & $\begin{array}{c}\text { Grupo de } \\
\text { Dominio Nativo } \\
\text { (GDN) }\end{array}$ & $\begin{array}{c}\text { Grupo de } \\
\text { Competencia } \\
\text { Limitada } \\
\text { (GCL) }\end{array}$ \\
\hline México & 127.792 .286 & $96,8 \%$ & 123.702 .932 & 4.089 .353 \\
\hline Colombia & 50.372 .424 & $99,2 \%$ & 49.969 .445 & 402.979 \\
\hline España & 47.026 .208 & $92 \% 9$ & 43.264 .111 & 3.762 .097 \\
\hline Argentina & 45.376 .763 & $98,1 \%$ & 44.514 .605 & 862.158 \\
\hline Perú & 32.625 .948 & $86,6 \%$ & 28.254 .071 & 4.371 .877 \\
\hline Venezuela & 32.605 .423 & $97,3 \%$ & 31.725 .077 & 880.346 \\
\hline Chile & 19.458 .310 & $95,9 \%$ & 18.660 .519 & 797.791 \\
\hline Guatemala & 17.915 .568 & $78,3 \%$ & 14.027 .890 & 3.887 .678 \\
\hline Ecuador & 15.954 .438 & $95,8 \%$ & 15.284 .352 & 670.086 \\
\hline Bolivia & 11.633 .371 & $83,0 \%$ & 9.655 .698 & 1.977 .673 \\
\hline Cuba & 11.326 .616 & $99,8 \%$ & 11.303 .963 & 22.653 \\
\hline República Dominicana & 10.448 .499 & $97,6 \%$ & 10.197 .735 & 250.764 \\
\hline Honduras & 9.304 .380 & $98,7 \%$ & 9.183 .423 & 120.957 \\
\hline
\end{tabular}




\begin{tabular}{|l|c|c|c|c|}
\hline Paraguay & 7.252 .672 & $68,2 \%$ & 4.946 .322 & 2.306 .350 \\
\hline Nicaragua & 6.624 .554 & $97,1 \%$ & 6.432 .442 & 192.112 \\
\hline E1 Salvador & 6.453 .553 & $99,7 \%$ & 6.434 .192 & 19.361 \\
\hline Costa Rica & 5.111 .238 & $99,3 \%$ & 5.075 .459 & 35.779 \\
\hline Panamá & 4.278 .500 & $91,9 \%$ & 3.931 .942 & 346.559 \\
\hline Uruguay & 3.473 .730 & $98,4 \%$ & 3.418 .150 & 55.580 \\
\hline Puerto Rico & 3.195 .153 & $99,0 \%$ & 3.163 .201 & 31.952 \\
\hline Guinea Ecuatorial & 1.225 .377 & $74,0 \%$ & 906.779 & 318.598 \\
\hline & 469.455 .011 & $94,6 \%{ }^{27}$ & 444.052 .308 & 25.402 .703 \\
\hline
\end{tabular}

Fuente: "El español como lengua viva- Informe 2020" - Instituto Cervantes (CVC.Cervantes.es)

Asimismo en el siguiente cuadro podemos ver el número de hispanohablantes en países donde el español no es lengua oficial, con datos de grupo de dominio nativo y grupo con competencia limitada; podemos apreciar que en algunos de los países donde el español no es lengua oficial hay grupos de hispanohablantes bastante importantes:

\begin{tabular}{|l|c|c|}
\hline \multicolumn{4}{|c|}{ Hispanohablantes en países donde el español no es lengua oficial } \\
\hline \multicolumn{1}{|c|}{ País } & $\begin{array}{c}\text { Grupo Dominio } \\
\text { Nativo }\end{array}$ & $\begin{array}{c}\text { Grupo Competen- } \\
\text { cia Limitada }\end{array}$ \\
\hline Estados Unidos & 41.460 .427 & 14.900 .000 \\
\hline Unión Europea & 1.400 .000 & 30.975 .000 \\
\hline Marruecos & 6.586 & 1.664 .823 \\
\hline Canadá & 439.110 & 293.000 \\
\hline Brasil & 460.018 & 96.000 \\
\hline Australia & 117.498 & 374.571 \\
\hline Filipinas & 4.476 & 461.689 \\
\hline Argelia & 175.000 & 48.000 \\
\hline Belice & 165.296 & 36.000 \\
\hline Israel & 130.000 & 45.000 \\
\hline Antillas Neerlandesas (Bonaire, Curazao, San & 10.006 & 140.670 \\
\hline Eustaquio, Saba, San Martín) & 124.000 & \\
\hline Suiza & 108.000 & \\
\hline Japón & & \\
\hline
\end{tabular}




\begin{tabular}{|l|c|c|}
\hline Aruba & 13.710 & 69.354 \\
\hline Trinidad y Tobago & 4.000 & 66.401 \\
\hline Guam (Estados Unidos) & 1.201 & 59.381 \\
\hline Andorra & 30.414 & 16.857 \\
\hline Noruega & 13.000 & 24.000 \\
\hline Nueva Zelanda & 22.000 & \\
\hline Sáhara Occidental & & 22.000 \\
\hline Islas Vírgenes (Estados Unidos) & 16.788 & \\
\hline Turquía & 1.000 & 15.000 \\
\hline Jamaica & 8.000 & \\
\hline China & 5.000 & \\
\hline Rusia & 3.000 & \\
\hline India & 1.000 & \\
\hline Total & 44.715 .054 & 49.307 .746 \\
\hline
\end{tabular}

Fuente: “El español como lengua viva- Informe 2020” - Instituto Cervantes (CVC.Cervantes.es)

El siguiente cuadro es un resumen del número de hispanohablantes tanto en el mundo hispánico (países donde el español es lengua oficial) como fuera del mundo hispánico (países donde el español no es idioma oficial), vemos que en total se calcula que actualmente hablan español más de 585 millones de personas, incluídos los hablantes de dominio nativo, los de dominio limitado y los estudiantes de español como lengua extranjera:

\begin{tabular}{|l|c|c|c|}
\hline \multicolumn{4}{|c|}{ Cablantes de español $^{3}$} \\
\hline & $\begin{array}{c}\text { Mundo hispá- } \\
\text { nico }\end{array}$ & $\begin{array}{c}\text { Fuera del mundo } \\
\text { hispánico }\end{array}$ & Totales \\
\hline $\begin{array}{l}\text { Grupo de Dominio Nativo } \\
\text { (GDN) }\end{array}$ & 444.052 .308 & 44.715 .054 & 488.767 .362 \\
\hline $\begin{array}{l}\text { Grupo de Competencia Limitada } \\
\text { (GCL) }\end{array}$ & 25.402 .703 & 49.307 .746 & 74.710 .449 \\
\hline $\begin{array}{l}\text { Grupo de Aprendices de Lengua } \\
\text { Extranjera (GALE) }\end{array}$ & & & 22.329 .275 \\
\hline \begin{tabular}{l} 
Grupo de usuarios potenciales \\
\hline
\end{tabular} & & & 585.807 .086 \\
\hline
\end{tabular}

Fuente: "El español como lengua viva- Informe 2020" - Instituto Cervantes (CVC.Cervantes.es) 
En el siguiente gráfico podemos apreciar el porcentaje de producción científica agregada de los países hispanohablantes en comparación con la de los principales países angloparlantes, vemos que el porcentaje de la producción científica en inglés es bastante superior al porcentaje de la producción científica en español:

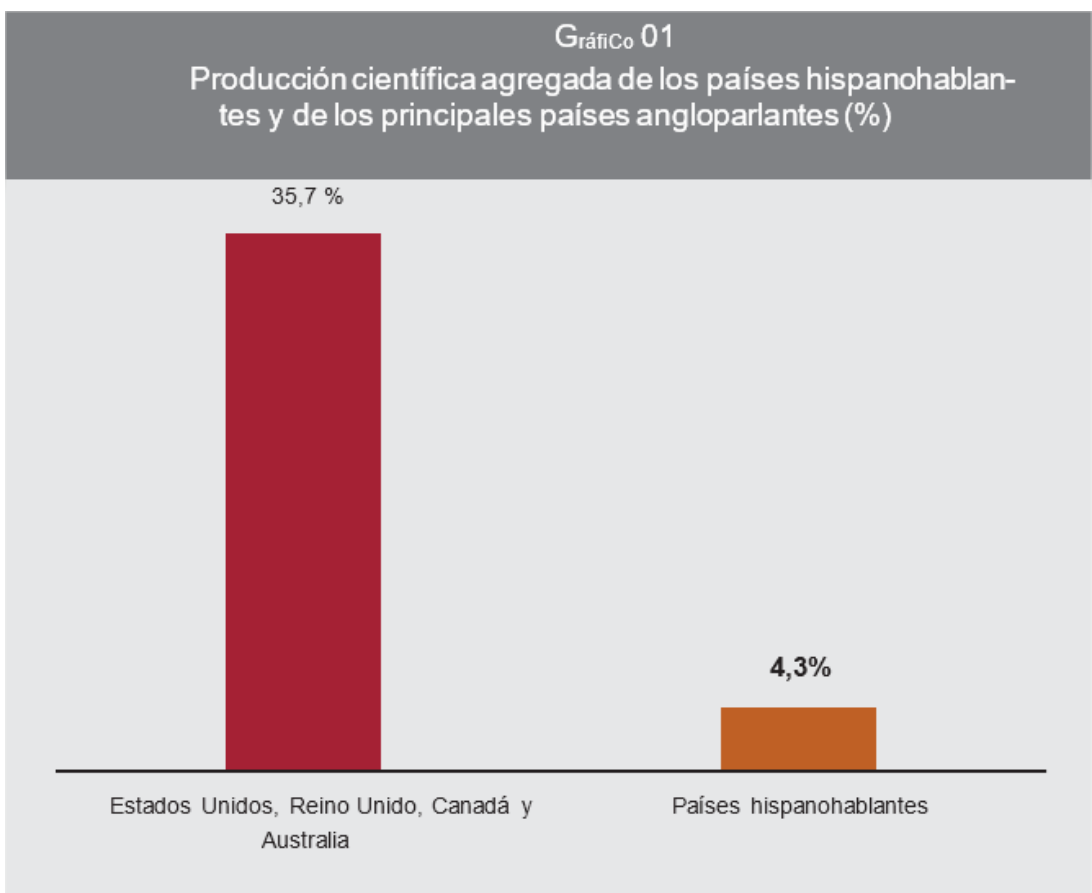

Fuente: “El español como lengua viva- Informe 2020" - Instituto Cervantes (CVC.Cervantes.es)

\section{ENSEÑANZA DEL IDIOMA ESPAÑOL:}

La enseñanza del idioma español se está volviendo cada vez más común en el mundo, actualmente podemos ver que la enseñanza del español tanto en escuelas, universidades o en escuelas de español para extranjeros es más común que en el pasado, incluso ahora en este contexto de pandemia que estamos viviendo la enseñanza del español no ha parado y continúa dándose por plataformas digitales.

En el siguiente cuadro podemos ver los datos mencionados sobre el número de estudiantes de español en el mundo para el año 2020, incluyendo en- 
señanza primaria, secundaria, formación profesional, enseñanza universitaria, centros del Instituto Cervantes y otros. Cabe resaltar que en "otros" se consigna información sobre la enseñanza no reglada (como por ejemplo en institutos privados, aunque no hay mucha información sobre éstos). Como podemos ver en el Cuadro, se estima que en 2020 más de 22 millones de alumnos estudiaban español como lengua extranjera en el mundo, pero se estima que hay un número de estudiantes de español aún no contabilizado que podría rondar los 5 millones.

\begin{tabular}{|c|c|c|c|c|c|c|}
\hline \multicolumn{7}{|c|}{$\begin{array}{c}\mathrm{C}_{\text {uadro }} 4 \\
\text { Número aproximado de estudiantes de español en el mundo. } \\
\text { Clasificación por países }\end{array}$} \\
\hline & & $\begin{array}{l}\text { Enseñanza } \\
\text { primaria, } \\
\text { secundaria } \\
\text { y formación } \\
\text { profesional }\end{array}$ & $\begin{array}{l}\text { Enseñan- } \\
\text { za univer- } \\
\text { sitaria }\end{array}$ & Otros & $\begin{array}{l}\text { Centros del Ins- } \\
\text { tituto Cervantes } \\
\text { 2018-2019 }\end{array}$ & Total \\
\hline 1. & $\begin{array}{l}\text { Estados } \\
\text { Unidos }\end{array}$ & 7.363 .125 & 712.240 & - & 3.248 & 8.082 .044 \\
\hline 2. & Brasil & 4.467 .698 & - & & 4.431 & 6.120 .000 \\
\hline 3. & UE-28 & 4.697 .196 & - & - & - & 5.257 .790 \\
\hline 4. & Francia & 2.701 .176 & - & 5.978 & 4.225 & 2.710 .015 \\
\hline 5. & Alemania & 584.617 & 52.947 & 182.980 & 5.892 & 820.544 \\
\hline 6. & Italia & 760.078 & - & 2.151 & 4.732 & 766.961 \\
\hline 7. & $\begin{array}{c}\text { Costa de } \\
\text { Marfil }\end{array}$ & 563.091 & 3.087 & - & - & 566.178 \\
\hline 8. & $\begin{array}{l}\text { Reino } \\
\text { Unido }\end{array}$ & - & 6.249 & - & 4.379 & 519.660 \\
\hline 9. & Benín & - & - & - & - & 412.515 \\
\hline 10. & Senegal & - & - & - & 2 & 205.000 \\
\hline 11. & Suecia & 190.710 & 5.572 & 6.781 & 475 & 203.538 \\
\hline 12. & Camerún & - & - & - & - & 193.018 \\
\hline 13. & Gabón & - & - & - & - & 167.410 \\
\hline 14. & España & - & - & - & - & 130.000 \\
\hline
\end{tabular}




\begin{tabular}{|c|c|c|c|c|c|c|}
\hline 15. & $\begin{array}{c}\text { Guinea } \\
\text { Ecuatorial }\end{array}$ & - & - & - & - & 128.895 \\
\hline 16. & Portugal & 92.122 & 4.850 & - & 502 & 97.474 \\
\hline 17. & Canadá & - & & 3.928 & 85 & 92.853 \\
\hline 18. & Polonia & 86.316 & - & 3.928 & 2.204 & 92.448 \\
\hline 19. & Noruega & 89.188 & 587 & - & - & 89.775 \\
\hline 20. & Marruecos & 69.819 & 2.692 & - & 9.356 & 85.456 \\
\hline 21. & Japón & - & - & - & 907 & 60.000 \\
\hline 22. & China & 8.874 & 34.823 & 8.866 & 2.722 & 55.285 \\
\hline 23. & Irlanda & 45.291 & - & - & 1.782 & 47.073 \\
\hline 24. & Bélgica & 13.982 & 7.428 & 23.253 & 817 & 45.480 \\
\hline 25. & Australia & 34.560 & 8.275 & - & 758 & 43.593 \\
\hline 26. & Filipinas & 13.500 & 16.000 & 11.500 & 2.861 & 41.000 \\
\hline 27. & Dinamarca & 35.427 & - & - & - & 39.501 \\
\hline 28. & $\begin{array}{l}\text { República } \\
\text { Checa }\end{array}$ & 28.048 & 8.317 & - & 1.143 & 37.508 \\
\hline 29. & Austria & 35.190 & 1.244 & - & 857 & 37.291 \\
\hline 30. & $\begin{array}{l}\text { Nueva } \\
\text { Zelanda }\end{array}$ & 33.136 & 2.747 & - & - & 35.883 \\
\hline 31. & Rusia & 25.599 & - & 4.418 & 2.337 & 32.354 \\
\hline 32. & Túnez & 29.626 & - & 1.046 & 928 & 31.980 \\
\hline 33. & Países Bajos & 30.000 & - & 1.399 & 442 & 31.841 \\
\hline \multicolumn{2}{|c|}{ Total (110 países) } & & & & & 22.329 .275 \\
\hline
\end{tabular}

Fuente: “El español como lengua viva- Informe 2020” - Instituto Cervantes (CVC.Cervantes.es)

En el siguiente gráfico podemos ver los principales países donde se estudia el español como lengua extranjera en porcentajes, siendo Estados Unidos, Brasil y la Unión Europea los países donde se concentra casi el 90 \% de los estudiantes de español que hay en el mundo: 


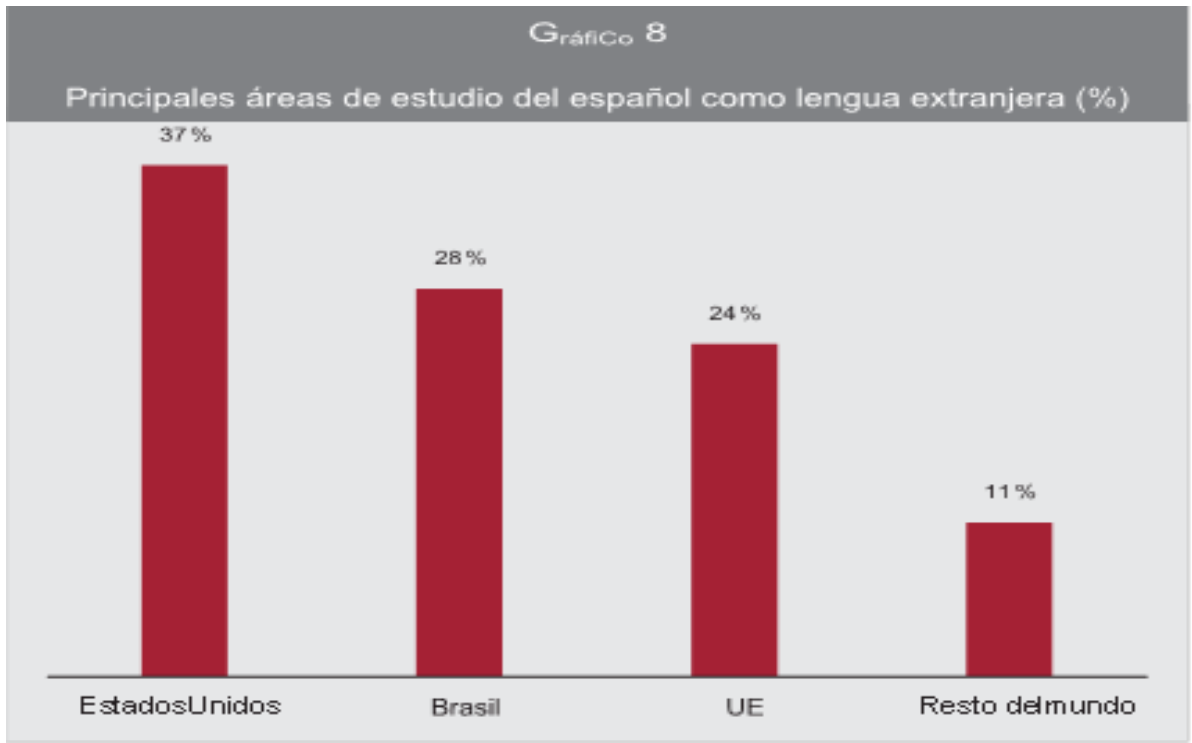

Fuente: “El español como lengua viva- Informe 2020” - Instituto Cervantes (CVC.Cervantes.es)

Asimismo en el siguiente gráfico podemos ver como ya se dijo, que el español es el cuarto idioma más estudiado como lengua extranjera con aproximadamente 22 millones de estudiantes; después del inglés que es la lengua franca mundial por excelencia, del francés y del chino mandarín:

Gráfico 9: Número de alumnos de los idiomas más estudiados como lengua extranjera (en millones)

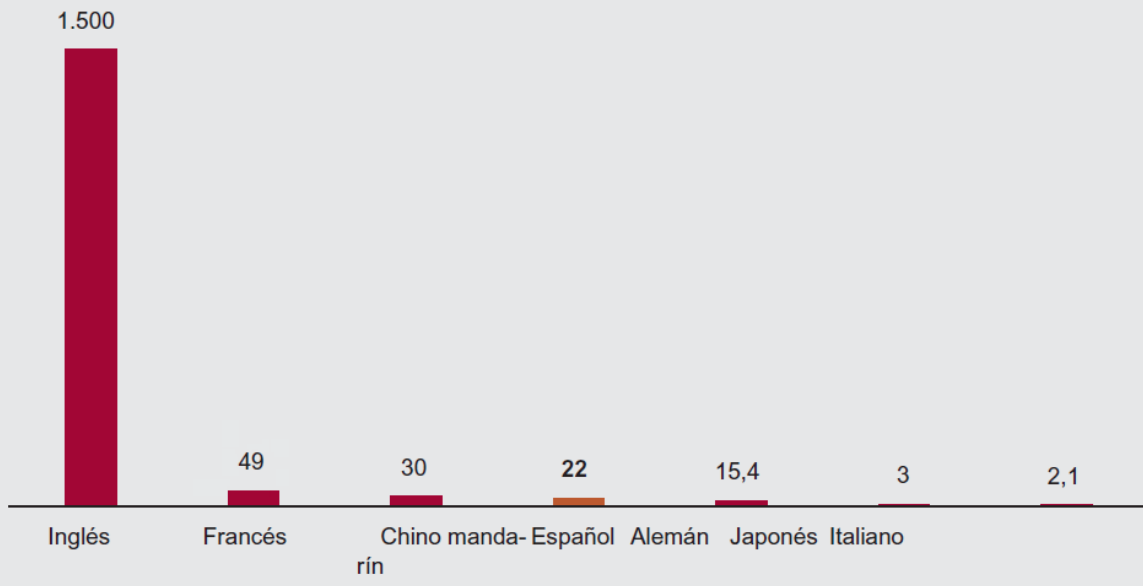

Fuente: "El español como lengua viva- Informe 2020" - Instituto Cervantes (CVC.Cervantes.es) 


\subsection{Turismo Cultural y Turismo Idiomático:}

En los últimos años se está viendo que el turismo cultural hacia América Latina se ve complementado con estudios del idioma español, es decir los turistas de diferentes países del mundo con diferentes idiomas nativos aprovechan su viaje a países de Latinoamérica para estudiar y practicar el español algunas semanas o meses mientras dure su estadía en el país que están visitando lo que se conoce como estudios de inmersión, ya que al estar las personas en un país donde todos hablan el idioma objetivo en este caso el español, el estudiante tiene la oportunidad de escuchar y practicar el idioma en un contexto académico y también fuera de la escuela en un contexto de la vida real.

Es por esto que en países con bastante afluencia de turistas como Perú, Méjico, Guatemala y otros países de América Latina, en los últimos años han ido aumentando el número de escuelas de español para extranjeros con facilidades que se acomoden a su disponibilidad de tiempo, con paquetes turísticos, acomodación en una vivienda y con una enseñanza bastante buena. En este contexto los extranjeros aprenden el español por inmersión como ya se mencionó, al estar en contacto con el idioma objetivo todo el día y todos los días..

En el siguiente gráfico podemos apreciar que con casi 285000 estudiantes, el hispanohablante es el segundo ámbito lingüístico que más alumnos extranjeros acoge para realizar cursos de aprendizaje o perfeccionamiento del idioma:

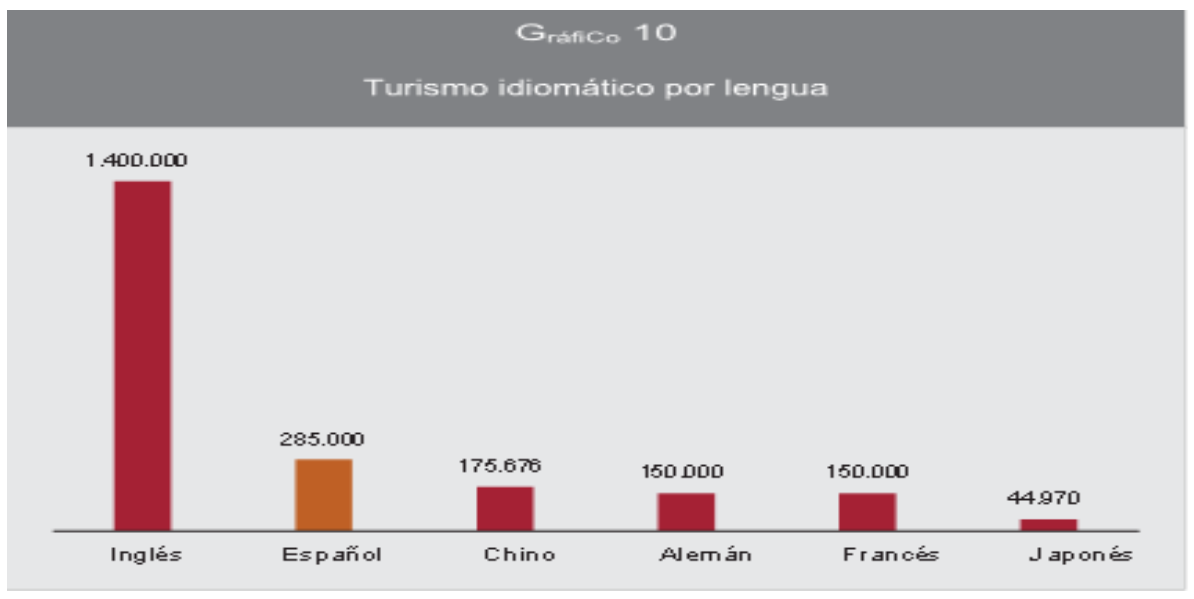

Fuente: "El español como lengua viva- Informe 2020" - Instituto Cervantes (CVC.Cervantes.es) 
La enseñanza del español para extranjeros en escuelas de español para extranjeros privadas, en países latinos, es una experiencia bastante enriquecedora tanto para los estudiantes de español como para los profesores al ser un intercambio cultural en un ambiente académico cordial y relajado. La enseñanza de español para extranjeros en países latinos tiene diferentes niveles: los estudiantes que son básicos y quieren aprender español de supervivencia para poder comunicarse mientras estén en el país o países de Latinoamérica que estén visitando; los estudiantes que ya tienen conocimientos previos del idioma porque lo han estudiado o aprendido en sus países (en la escuela o fuera de la escuela) o que ya han hecho viajes anteriores a países de Latinoamérica y que generalmente tienen un nivel intermedio en el español; estudiantes que estudian español en sus universidades como parte de sus estudios profesionales por ejemplo ahora es cada vez más común personas que estudian la Carrera de Cultura Latinoamericana y que tienen un nivel intermedio o avanzado del español y desean perfeccionar y profundizar sus conocimientos sobre el idioma y la cultura de Latinoamérica, por ejemplo en mi experiencia he tenido varios estudiantes japoneses que pertenecen a este grupo, ellos al estudiar Cultura Latinoamericana y español en su país de origen tienen bastante habilidad, dominio y conocimientos sobre la cultura latinoamericana y dominan bastante bien el idioma español, claro que al ser su idioma nativo el japonés muy diferente al español necesitan bastante práctica y esfuerzo para perfeccionarlo, incluso algunos de ellos a la vez de venir a Cusco-Perú para perfeccionar sus estudios de español y cultura latinoamericana también aprovechan para llevar cursos de quechua ya que Cusco fue la capital de Imperio de los Inkas y cuna del idioma quechua. También hay estudiantes que van a rendir exámenes internacionales como exámenes DELE (Diploma de Español como Lengua Extranjera) generalmente de nivel intermedio o de nivel avanzado y que necesitan practicar el idioma español desde un enfoque más académico. Además también hay estudiantes que quieren hacer prácticas de conversación que generalmente tienen un nivel avanzado en el idioma y quieren perfeccionarlo o los que quieren practicar en campos específicos como: español médico, español financiero, literatura peruana o latinoamericana y otros. Todos estos niveles y requerimientos 
de los estudiantes de español en países de Latinoamérica requieren diferentes tipos de enfoque y técnicas en la enseñanza del idioma español.

\subsection{La Enseñanza del Idioma Español a Brasileños:}

\subsubsection{El Español en Brasil:}

El idioma español siempre ha tenido bastante influencia e importancia en Brasil por estar ubicado en Sudamérica con países vecinos hispanohablantes. El español es ofrecido como primera lengua extranjera de enseñanza en los colegios y liceos de Brasil, siendo su enseñanza obligatoria en varios estados del país:

El español siempre ha sido importante en Brasil a causa de la proximidad y el comercio creciente con sus vecinos hispanoamericanos, siendo miembro de Mercosur, así como por la inmigración histórica de españoles e hispanoamericanos. En 2005, el Congreso Nacional de Brasil aprobó el decreto, firmado por el Presidente, conocido como Ley del Español, que ofrece esta lengua como primera lengua extranjera de enseñanza en los colegios y liceos del país. El español es una lengua fácil de aprender para los brasileños, gracias a que el portugués es una lengua muy similar al español. En la zona fronteriza entre Brasil y Uruguay (principalmente en Uruguay) se habla de una lengua mixta llamada portuñol. La Constitución del Estado de Río de Janeiro y una deliberación del Gobierno del Estado de Sao Paulo incluyen el español de modo oficial en los centros de enseñanza secundaria. Así el Artículo 317.3 de la Constitución del Estado de Río de Janeiro de 1989 declara: "La lengua española pasa a formar parte del núcleo obligatorio de disciplinas de todas las series del segundo grado de la red estatal de enseñanza, teniendo en cuenta primordialmente, lo que establece la Constitución de la República en su artículo cuarto, párrafo único". Y el artículo 2 de la deliberación $\mathrm{N}^{\circ} 77$ del Consejo Estatal de Educación del Gobierno del Estado de Sao Paulo de 2008 reconoce: "El español es un componente curricular obligatorio, según la legislación federal en vigor, a ser desarrollado de acuerdo con los términos de las orientaciones contenidas en la indicación cee $\mathrm{N}^{\circ} 77 / 08$ que forma parte de la deliberación”. La UNILA, Universidad Pública de la región sur brasileña que coordina y proporciona profesorado 
de castellano a las escuelas estatales de Río Grande del Sur, Santa Catarina y Paraná, cooficializó el español. En los últimos años, debido a la crisis migratoria venezolana, el fronterizo estado brasileño de Roraima ha pasado a ser el lugar con más habitantes que hablan español de Brasil. Se estima que alrededor de 50.000 venezolanos residen actualmente en Roraima, lo que constituye aproximadamente el 10 \% de la población del Estado. En 2018 el Estado de Río Grande del Sur reconoció al español en su Constitución como lengua de enseñanza obligatoria (“Idioma Español”Wikipedia).

\section{TEMAS DE LA CHARLA:}

\subsection{Para ustedes ¿Cuáles son las principales dificultades que los brasileños encuentran a la hora de hablar fluido el español? ¿Tales dificultades se hallan más en la pronunciación, acento, dominio de la morfosintaxis o en la incomprensión de las jergas, expresiones y dichos locales?}

En mi experiencia yo he visto que generalmente los estudiantes brasileños tienen un nivel intermedio o avanzado cuando vienen a Cusco a estudiar y/o practicar español porque ya han estudiado español en su país o porque están familiarizados con el español y la cultura latina ya que al estar Brasil en Sudamérica recibe mucha influencia del español por los medios de comunicación masiva como la televisión, internet o por migrantes de los países vecinos. Además los brasileños al ser generalmente de carácter extrovertido aprenden y hablan el idioma español sin pensar mucho en las reglas y sin temor de cometer errores casi como un idioma nativo ya que al ser el español y el portugués de la misma familia de idiomas son bastante parecidos en muchos aspectos: en muchas palabras, en la morfosintaxis, en la estructura de las oraciones, en las jergas o dichos locales y en otros aspectos.

Pienso que la pronunciación no es una gran dificultad para los estudiantes brasileños, tal vez lo es más para los estudiantes básicos. Los estudiantes brasileños hablan español de forma natural porque están familiarizados con el idioma y la cultura. 
Algunos aspectos a tomar en cuenta son que en español y portugués hay palabras muy parecidas pero con una escritura y pronunciación ligeramente diferente, esto les da a los estudiantes brasileños una falsa seguridad, especialmente a los estudiantes básicos y también los sonidos diferentes como los sonidos nasales del portugués que no existen en español y que los estudiantes brasileños deben tratar de suavizar cuando hablan en español.

El acento es una dificultad que enfrentan casi todos los estudiantes brasileños tanto a nivel básico, intermedio y avanzado lo que es normal cuando se estudia otro idioma, pero la mayoría de estudiantes brasileños no se preocupan mucho por esto; quizás este aspecto es más importante para los estudiantes más avanzados o los que están preparándose para un examen internacional como un examen DELE o los que son profesores de idiomas y tienen conocimientos de los aspectos que son importantes cuando se estudia otro idioma, esta dificultad se puede superar con la práctica o viviendo en el país donde se habla el idioma objetivo, aunque es un proceso largo que va a requerir bastante esfuerzo y dedicación del estudiante.

\subsection{Comparándolos con los demás extranjeros (principalmente italianos y franceses) ¿Se puede decir que los brasileños llegan más rápidamente a la fluidez? ¿Los estudiantes brasileños en general demuestran preocupación por hablar lo más cerca posible a un nativo?}

Comparando a los estudiantes brasileños con los demás estudiantes extranjeros especialmente con los italianos y franceses, yo pienso que los estudiantes brasileños alcanzan la fluidez más rápido. Los estudiantes franceses e italianos aunque son latinos también son europeos entonces mantienen muchas características de los europeos, en cambio los estudiantes brasileños por ser sudamericanos tienen mucho más en común con los latinoamericanos y están más familiarizados con el idioma español y la cultura latinoamericana. Por estas razones en general cuando los estudiantes brasileños vienen a un país de Latinoamérica para estudiar español no son muy básicos, así no hayan estudiado español en su país, es decir casi nunca empiezan desde cero y pueden 
lograr más rápido la fluidez. En realidad muchos estudiantes brasileños vienen de su país ya teniendo fluidez en español. Pienso que no se preocupan mucho por hablar lo más cerca posible a un nativo porque hablan de forma natural casi siempre conservando el acento característico del portugués. En mi experiencia también debo decir que influye mucho la personalidad de los brasileños que en general son bastante extrovertidos y eso hace que hablen en forma natural, aunque no se puede generalizar porque también he tenido algunos estudiantes brasileños más reservados e introvertidos que generalmente también eran básicos y al ser introvertidos y reservados eso hacía que su progreso no fuera tan rápido como el de sus compatriotas más extrovertidos, ya que al no hablar mucho no practicaban lo suficiente la expresión oral, claro que los profesores hacemos lo posible para revertir esa situación con motivación y técnicas para que el estudiante supere esos obstáculos.

\subsection{Desde su punto de vista ¿Cuáles de las técnicas y métodos para la en- señanza del español resultan más eficientes para la enseñanza a estudiantes brasileños?}

Primero haré em resumen de los principales enfoques em la enseñanza de lenguas extranjeras, las principales teorías del aprendizaje de idiomas y los principales métodos y técnicas para la enseñanza de lenguas extranjeras y después haré em análisis sobre cuáles de estos enfoques y métodos resultan más eficientes para la enseñanza del español a estudiantes extranjeros, especialmente a estudiantes brasileños:

Enfoques em la enseñanza de lenguas extranjeras:

Podemos ver diferentes enfoques em la enseñanza de acuerdo a em que se centre la enseñanza:

La enseñanza centrada em las actividades o tareas a realizar.

La enseñanza centrada em el contenido a enseñar: puede ser em tema completo durante todo el ciclo, por ejemplo "La primera guerra mundial" este tipo de enseñanza generalmente se usa para estudiantes avanzados; o pueden ser diferentes temas cortos, este tipo de enseñanza generalmente se usa 
para estudiantes básicos e intermedios.

La enseñanza centrada em el estudiante.

La enseñanza centrada em la forma (gramática, vocabulario).

Teorías del Aprendizaje de Idiomas: Actualmente hay muchas teorías sobre los métodos y técnicas para la enseñanza de lenguas extranjera, entre ellas tenemos:

Teoría Cognitivista: Los estudiantes aprenden las reglas del idioma objetivo.

Teoría Conductista: Los estudiantes son expuestos al idioma objetivo y por repetición crean em hábito de hablarlo.

Teoría Constructivista: Los estudiantes practican el idioma objetivo mediante la interacción em otros estudiantes.

Métodos y técnicas para la enseñanza de lenguas extranjeras Aprendizaje cognitivo: Mayormente enseñanza de reglas gramaticales, vocabulario y estructuras, está basado em la teoría cognitivista. Em este tipo de aprendizaje puede haber falta de habilidades comunicativas por em exceso de explicación de la gramática.

Método audiolingüístico: Mayormente desarrolla las habilidades de hablar y escuchar, se enfoca em la producción oral, está basado em la teoría conductista. Sin embargo, se pueden descuidar las habilidades de leer y escribir. Se puede usar para objetivos específicos como mejorar la pronunciación y el vocabulario.

Enseñanza de Lenguaje comunicativo: Desarrollada em reacción a los otros métodos, es interactiva y usa lenguaje significativo, se enfoca em la fluidez y comunicación clara, busca desarrollar comunicación em la vida real, está basada em la teoría constructivista. Es em método altamente popular, sin embargo no siempre se alcanza exactitud em la comunicación y se pueden descuidar las habilidades de leer y escribir.

Método Ecléctico: Es em combinación de los métodos anteriormente descritos, dependiendo de diferentes factores como las necesidades y objetivos del estudiante, la forma de aprender del estudiante, etc. Se considera em buen método porque combina diferentes formas de aprendizaje. (Traducido y resumido de "TEACHER DEVELOPMENT INTERACTIVE”- Fundamentals-Blended Course - Hunter College de Nueva York). 
Desde mi punto de vista no hay em método mejor que em, lo mejor es usar em combinación de todos estos métodos, basados em las teorías del aprendizaje, es decir el método ecléctico, para dar a los estudiantes más oportunidades de aprender. Se debe encontrar em equilibrio entre el punto de vista del profesor, el programa de la institución y las necesidades y objetivos de los estudiantes, em esto tiene mucho que ver la experiencia del profesor.

Em el caso específico de los estudiantes brasileños, como ya dijimos cuando vienen a estudiar español a em país de Latinoamérica generalmente son intermedios o avanzados, casi nunca son básicos; esto se debe a que han estudiado español em su país o porque, al estar Brasil ubicado em Sudamérica están muy familiarizados em la cultura latinoamericana y el idioma español; y también porque el español y el portugués son idiomas similares al pertenecer a la misma familia de idiomas (idiomas latinos). Por tanto sean básicos, intermedios o avanzados hacen progresos rápidamente y aprenden y hablan el idioma casi como em nativo, em raras excepciones.

Em general se empieza em em pequeña entrevista para determinar el nivel exacto del estudiante, si el estudiante es básico se empieza em vocabulario y gramática básica em sus respectivos ejercicios escritos; comprensión y análisis de lecturas simples; comprensión auditiva, por ejemplo em canciones sencillas em tiempo presente; prácticas de conversación de acuerdo al progreso que vaya logrando el estudiante y em temas que sean de su interés. Los estudiantes brasileños así sean básicos (que son muy pocos casos) casi inmediatamente empiezan a hablar el español y a progresar rápidamente em el idioma, em muy pocas excepciones que ya mencionamos que pueden ser estudiantes muy básicos que no hayan tenido mucho contacto em el español antes o estudiantes reservados e introvertidos em los que es necesario hacer más motivación y dinámicas de trabajo, e incidencia em la gramática y em la práctica como ejercicios escritos y también em las prácticas de comprensión de lectura, comprensión auditiva y prácticas de conversación, tratando de hacer que el estudiante deje de lado su timidez y se sienta cómodo em temas que sean de su interés.

$\mathrm{Si}$ el estudiante es intermedio se hace em diagnóstico para determinar los temas a repasar, si es necesario se empieza haciendo em revisión de los 
temas gramaticales que el estudiante necesite repasar o reforzar de acuerdo al diagnóstico que se hizo, em sus respectivas prácticas como comprensión y análisis de lecturas em poco más complejas, comprensión auditiva em audios, canciones y videos de nivel intermedio como documentales donde se pueda practicar temas intermedios como pasados, futuro, condicional; y prácticas de conversación dirigidas de acuerdo a los intereses del estudiante.

Em los estudiantes avanzados, si es necesario se hace em repaso breve de los temas gramaticales que se necesite reforzar, em sus respectivas prácticas, haciendo incidencia em análisis de lecturas más elaboradas y em las prácticas de comprensión auditiva em audios, canciones o videos más complejos, donde se pueda practicar temas intermedios y avanzados como imperativo, condicional y subjuntivo; y también hacemos bastante incidencia em las prácticas de conversación dirigidas de acuerdo a los temas de su interés, proyectos y exposiciones sobre su profesión o sobre la carrera que estén estudiando. Para citar algunos ejemplos: yo tuve unos estudiantes brasileños de nivel intermedio-avanzado em español que estaban em los últimos ciclos de finanzas em su Universidad em Brasil, em los que como parte de las prácticas del curso de español teníamos diálogos sobre la vida y la economía em su país y em otros países y a los que asigné em exposición sobre la economía em América Latina y Brasil em relación em el resto del mundo, su exposición fue muy completa y muy interesante; cabe resaltar que los estudiantes brasileños son muy responsables y tienen mucho interés em temas de actualidad mundial y son muy eficientes em sus estudios y em sus profesiones. También tuve otros estudiantes brasileños que estudiaban literatura latinoamericana em su Universidad em Brasil em los que como parte de las prácticas del curso de español hacíamos exposiciones, análisis y debates sobre obras de la literatura latinoamericana, ellos denotaban bastante conocimiento de la literatura latinoamericana y de los autores de obras latinoamericanas y tenían bastante dominio del idioma español incluyendo formas literarias y hacían análisis bastante completos de las obras literarias.

También debo decir que la enseñanza del idioma español a los estudiantes brasileños es muy reconfortante e interesante porque em ellos podemos hacer análisis profundos de diferentes temas, como lo haríamos em estudian- 
tes de nivel universitario o em profesionales nativos de español, porque como vuelvo a repetir aprenden y hablan el idioma español casi como em idioma nativo y tienen mucho interés y son muy eficientes y responsables em las tareas que se les asigna y em las prácticas y actividades que realizamos.

\subsection{4. ¿Cuál es el papel de la Gramática Normativa em lo tocante a Lenguas Extranjeras?}

En cuanto a la enseñanza de la gramática normativa para la enseñanza de lenguas extranjeras, si es hecha en una forma comunicativa y en contexto tiene buenos resultados, pero hay que tener en cuenta que la gramática es sólo una parte del aprendizaje de un nuevo idioma, como ya dijimos se debe usar una mezcla de métodos y técnicas de enseñanza para dar al estudiante más oportunidades de aprender.

También es importante tomar en cuenta que las personas tienen diferentes formas de aprendizaje, algunos estudiantes aprenden mejor memorizando listas de palabras, otros son más visuales, otros son más auditivos, otros son kinestésicos, muchos tienen una mezcla de estas formas de aprendizaje; algunos prefieren el trabajo individual otros prefieren el trabajo en equipo. Por estas razones todos los aspectos son importantes: la gramática, ejercicios escritos, conversación, comprensión de lectura, comprensión auditiva, vocabulario, etc. Es importante el uso de materiales de trabajo como fichas, tarjetas, audios, videos. También son muy importantes las actividades interactivas como dinámicas grupales, juegos de roles, entrevistas, proyectos, etc. Así como la motivación y la actitud proactiva del profesor y de los estudiantes para crear un ambiente agradable para el aprendizaje.

\section{CONSIDERACIONES FINALES:}

De lo expuesto podemos concluir que:

Generalmente los estudiantes brasileños tienen un nivel intermedio o avanzado cuando van a un país de Latinoamérica a estudiar y/o practicar español porque ya han estudiado español en su país o porque están familia- 
rizados con el español y la cultura latinoamericana. Además los brasileños al ser generalmente de carácter extrovertido hablan el idioma español sin pensar mucho en las reglas y sin temor de cometer errores casi como un idioma nativo. La pronunciación no es una gran dificultad para los estudiantes brasileños, tal vez lo es más para los estudiantes básicos. Los estudiantes brasileños aprenden y hablan español de forma natural porque están familiarizados con el idioma y la cultura. Un aspecto en el que hay que tener cuidado es que en español y portugués hay palabras muy parecidas pero con una escritura y pronunciación ligeramente diferente, esto les da a los estudiantes brasileños una falsa seguridad, especialmente a los estudiantes básicos y también los sonidos diferentes como los sonidos nasales del portugués que no existen en español y que los estudiantes brasileños deben tratar de suavizar cuando hablan en español.

El acento es una dificultad que enfrentan casi todos los estudiantes brasileños tanto a nivel básico, intermedio y avanzado lo que es normal cuando se estudia otro idioma, pero la mayoría de estudiantes brasileños no se preocupan mucho por esto; quizás este aspecto es más importante para los estudiantes más avanzados o los que están preparándose para un examen internacional como un examen DELE o los que son profesores de idiomas, esta dificultad se puede superar con la práctica o viviendo en el país donde se habla el idioma objetivo, aunque es un proceso largo que va a requerir bastante esfuerzo y dedicación del estudiante.

En cuanto a la fluidez los estudiantes brasileños alcanzan la fluidez más rápido que otros estudiantes. En general cuando los estudiantes brasileños van a un país de Latinoamérica para estudiar español no son muy básicos, así no hayan estudiado español en su país, es decir casi nunca empiezan desde cero y pueden lograr más rápido la fluidez. Muchos estudiantes brasileños vienen de su país ya teniendo fluidez en español. No se preocupan mucho por hablar lo más cerca posible a un nativo porque hablan de forma natural, casi siempre conservando el acento característico del portugués. También influye mucho la personalidad de los brasileños que en general son bastante extrovertidos y eso hace que hablen en forma natural, aunque hay excepciones. 
En cuanto a los métodos y técnicas que son más eficientes para la enseñanza del idioma español no hay un método mejor que otro, lo mejor es usar una combinación de todos estos métodos, basados en las teorías del aprendizaje para dar a los estudiantes más oportunidades de aprender. Se debe encontrar un equilibrio entre el punto de vista del profesor, el programa de la institución y las necesidades y objetivos de los estudiantes, en esto tiene mucho que ver la experiencia del profesor. En el caso específico de los estudiantes brasileños, como ya dijimos cuando van a estudiar español a un país de Latinoamérica generalmente son intermedios o avanzados, casi nunca son básicos. Generalmente hacen progresos rápidamente y aprenden y hablan el idioma casi como un nativo, con raras excepciones.

En cuanto a la enseñanza de la gramática normativa para la enseñanza de lenguas extranjeras, si es hecha en una forma comunicativa y en contexto tiene buenos resultados, pero hay que tener en cuenta que la gramática es sólo una parte del aprendizaje de un nuevo idioma, como ya dijimos se debe usar una mezcla de métodos y técnicas de enseñanza para dar al estudiante más oportunidades de aprender, ya que los estudiantes tienen diferentes formas de aprendizaje.

\section{REFERENCIAS}

CHARLAS SIN FRONTERAS. Dificultades y Propuestas Metodológicas: Reflexiones acerca de la Enseñanza de ELE para brasileños. Proyectos Dale. Disponible en: https://www.youtube.com/watch?v=Hqs7EzWmSvA\&t=626s

“IDIOMA ESPAÑOL”. Disponible en https://es.m.wikipedia.org INSTITUTO CERVANTES “E1 Español una Lengua Viva”- Informe 2020 Disponible en:cvc.cervantes.es/lengua/espanol_lengua_viva/pdf/espanol_lengua_viva_2020.pdf

TEACHER DEVELOPMENT INTERACTIVE - Fundamentals - Blended Course - Hunter College de Nueva York 


\title{
CAPÍTULO 10. SOB O CRITÉRIO DA FALTA
}

\author{
Ademir Junior de Souza Pires \\ João Carlos Pereira Coqueiro \\ Helio Rodrigues da Rocha
}

\begin{abstract}
A imagem tradicional da América do Sul ilustra particularmente essa mistura de meias-verdades, de preconceitos, queleva a trataros fatos com umaleviandade surpreendente.

Pierre Clastres - A sociedade contra o Estado.
\end{abstract}

O lugar social também é um espaço institucional como a igreja, o poder monárquico em expansão ou a universidade.

Sobre viagens, viajantes e representações da Amazônia Adrián Padilla Fernández \& Maria Luiza Fernandes.

Sociedades indígenas são, em inúmeras narrativas de viajantes, sociedades da falta, como afirma o antropólogo francês Pierre Clastres, que "inventou um uso afirmativo da noção de sociedade primitiva, liberando-a de toda escala de complexidade e conferindo-lhe uma qualidade política por assim dizer absoluta” - conforme Tânia Lima e Márcio Goldman, no prefácio de $A$ sociedade contra o Estado (Clastres, 2020, p. 9). É seguindo essa ideia que viajamos na obra de um missionário no Chaco paraguaio. Zarpemos, pois.

É deveras comum - em textos produzidos por um grande número de cronistas, viajantes e missionários que se detiveram sobre aspectos econômicos de várias comunidades indígenas da América do Sul - nos depararmos com afirmativas negativas acerca do sistema social e econômico em que vivia a sociedade descrita. $\mathrm{O}$ texto/tradução/espelho que apresento logo abaixo é um desses retratos etnográficos que, diante do estado socialista dos nativos do Chaco paraguaio, o missionário anglicano W. Barbrooke Grubb julga ser preciso despedaçá-lo, e a sua descrição, portanto, tem aqui caráter demonstrativo de sua política colo- 
nialista e, obviamente, desrespeitosa em relação ao modo de vida da sociedade chaquenha espelhada por ele, a comunidade lengua-maskóy, com quem conviveu na última década do século XIX e a primeira do século XX.

Convém, por questões didáticas, esclarecer que Wilfred Barbrooke Grubb (1865-1930) gastou esse tempo de sua vida em estudos da cultura dos lengua-maskóy com a intenção de cristianizá-los e, para isso, mergulhou no cotidiano desse povo chaquenho, apropriou-se de vários de seus hábitos e crenças e aprendeu sua língua com o fito de desmantelá-los e usá-los contra o próprio povo com o qual conviveu.

Assim, nossa intenção, neste texto, é apresentar o capítulo XIX do relato de Grubb, que foi publicado em Londres pela Editora Seely, Service \& Co. Limited em 1911. Com a apresentação desse capítulo, pretendemos examinar o discurso grubbiano sobre o sistema econômico dos lengua-maskóy.

A partir da leitura de "Indian Socialism", capítulo XIX do livro An unknown people in an unknown land: an account of the life and customs of the lengua indians of the paraguayan chaco, with adventures and experiences durig twenty years'pioneering and exploration amongst them (1911), pode-se afirmar com certa segurança que o olhar de Grubb para a forma econômica dos lengua-maskóy emite um juízo de valor não somente de rejeição de tal sistema, como também acusa os nativos de ociosidade, de aversão ao trabalho, imprevidência, etc. e vê nessa forma de vida comunitária tão somente uma economia de subsistência que necessitava da intervenção do Estado; e isso significaria a intrusão da Sociedade Missionária da América do Sul por meio de seus estratagemas religiosos e colonialistas. Logo, o missionário é o vetor dessa política colonialista.

Acusados de serem imprevidentes, ociosos, preguiçosos, egoístas, aversos à ordem, dentre outras estereotipias, o missionário julga ser "absolutamente necessário opor-se a esse sistema social”, já que "o indígena, ao longo de gerações, se tornou um desprovido, preguiçoso e, em grande parte, egoísta, e perdeu todos os sentimentos por quem está fora de seu círculo familiar direto" (Grubb, 1911). É nesse intento de modificação do sistema econômica dos lengua-maskóy que Grubb vai trabalhar em sua atuação missioneira, sujeitar os lengua-maskóy a uma nova forma de economia política em que fundação de um posto missioná- 
rio operará como o centro do poder, o lugar em que a nova relação política de poder "fundamenta a relação econômica de exploração" (Clastres, 2020, p. 174) e de assujeitamento dessa sociedade chaquenha, pois o posto missionário, de fato uma redução à moda jesuítica, funcionaria como o panóptico foucaultiano, o olho que tudo deveria vigiar e punir. É essa nova ordem que divide a sociedade lengua-maskóy em classes e, assim, tem-se, nessa redução anglicana, a igreja, o armazém, a escola, o posto de saúde, e, em seus entornos, as casas das famílias nativas. Não se tem mais a casa comunal, a grande casa comunitária, porque, para desmantelar o sistema socialista é preciso primeiramente separar as pessoas em células familiares e "inculcar-lhes a ideia de garantir os direitos daqueles que adquiriram bens honestamente" (Grubb, 1911).

Agora, sob o comando do missionário, a sociedade lengua-maskóy não mais estaria sob o signo da incompletude, ou "sob o critério da falta" (Clastres, 2020), tendo em vista que, "nos últimos vinte anos" - assevera Grubb -

desde que uma completa revolução social ocorreu entre essas pessoas, não mais as encontramos vivendo num sistema comunista, mas como trabalhadores independentes, acumulando bens por meio de seus próprios esforços, e respondendo com alegria e entusiasmo ao chamado da civilização cristã (Grubb, 1911).

É, portanto, sob a égide da 'civilização cristã' que o missionário elabora a sua etnografia da falta sobre essa comunidade lengua-maskóy. O seu relato híbrido - pois se constitui de suas experiências e aventuras no interior do Chaco paraguaio, bem como de registros de observações um tanto quanto descomedidas da vida e dos costumes da comunidade etnografada e persuadida diuturnamente, além das invocações a concepções evolucionistas e capitalistas, seja por meio de citações de fontes bibliográficas, seja por meio de citações de experiências registradas por alguns de seus predecessores - é uma urdidura que procura demostrar aos leitores europeus, em especial, o quanto era necessário a intervenção da igreja anglicana nessas 'terras desconhecidas' e entre esse 'povo desconhecido' da América do Sul. Mas nós sabemos, e os estudos antropológicos e arqueológicos contemporâneos não cessam de mostrar e comprovar, que, muito antes da 
chegada dos europeus ao que eles vão denominar 'Novo Mundo', havia relações comerciais e empréstimos linguísticos entre os vários povos nativos.

Portanto, apesar de An unknown people in an unknown land [um povo desconhecido numa terra desconhecida] apoiar-se na experiência in situ, na reflexão sobre a vida dos lengua-maskóy e transmitir muitas informações valiosas sobre o Chaco e os nativos, é uma obra de cunho fortemente colonialista. Consequentemente, esse foi um dos critérios que usamos na seleção do capítulo que apresentamos ao leitor.

No processo engendrativo da obra há, entre as partes textuais, fotografias de indígenas em trajes típicos, de acampamentos e de tolderias, de artesãos, de caçadores, de artefatos materiais [cerâmicas e tear], de rituais diversos, de festas e de desenhos elaborados pelo viajante, ao que se pode presumir, e quatro apêndices que trazem dados geográficos, climáticos e antropométricos, além de algumas palavras do vocabulário lengua-maskóy.

No todo, o relato An unknown people in na unknown land (1911) é composto de trinta capítulos e quatro apêndices, como dito acima. $\mathrm{Na}$ edição de 1911 há um frontispício com uma fotografia de três mulheres lengua-maskóy prontas para participarem da "Puphek", dança na cerimônia "Yanmana". Segurando varas compridas de bambu com chocalhos feitos com pedaços do casco de cervos numa das extremidades, essas mulheres, trajando saias longas de lã de ovelhas, mas nuas da cintura pra cima, dançam no rito de passagem da jovem para a fase adulta, isto é, com esse ritual, a jovem lengua-maskóy estaria pronta para o casamento. Seria, portanto, o ritual de iniciação das meninas lengua-maskóy. Abramos parênteses para a descrição dada pelo missionário sobre esse ritual de passagem, isto é, de iniciação.

O cerimonial Yanmana é a comemoração da maioridade de uma menina e a principal característica dessa ritualística é que a menina se senta, com uma ou duas acompanhantes, em uma barraca especialmente construída para o evento. Ela é adornada com motivos alegres e, pela primeira vez, usa a saia longa das mulheres. Nessa festa ela deixa de ser criança. As mulheres dançam sozinhas, cada uma segurando uma vara comprida com um monte de cascos de cervos amarrados na ponta. Batem no chão com essas varas, produzindo 
um som estridente, marcando o ritmo de um canto que entoam. Dispostas em círculo, mantêm um passo regular, enquanto vão se movimentando.

Uma anciã no centro chocalha a vara e mantém o passo com as outras, cantando em uníssono, mas em um tom mais alto. Ela faz muitas contorções estranhas, às vezes fingindo arrancar seu próprio cabelo. Os homens também formam um círculo, cada um segurando uma cabaça cheia de sementes e conchinhas, que eles chocalham com um movimento uniforme, mantendo o ritmo do canto. Os meninos, paramentados com plumas de avestruz, usam máscaras que representam espíritos malignos, e, correndo um atrás do outro, entram e saem da multidão, tilintando cordões de cascos de animais, e, de vez em quando, dando gritos estridentes e prolongados. Quando circulam perto da garota, as mulheres os afastam. A cerimônia Yanmana dura seis ou sete semanas. Se ocorrerem durante os meses de verão, bebidas embriagantes são bastante consumidas. O vício prevalece nessas festas (Grubb, 1911).

Tanto essa representação etnográfica, quanto várias outras que estão espraiadas no relato de Grubb são muito importantes para estudiosos das culturas indígenas da América do Sul, bem como para a memória e tradição desse povo chaquenho, no entanto, ao que se pode presumir, elas contribuem para convencer leitores afeitos à cultura e à razão ocidental cristã que os lengua-maskóy precisavam ser retirados desse mundo pagão, algo que o missionário anglicano dedicará duas décadas de sua vida para combater. Assim é que a sua etnografia possui um caráter explicitamente colonizador. Devem os lengua-maskóy deixar suas tradições e abraçar o modelo de vida europeu. Logo, Grubb não escuta o indígena, não dialoga; ele impõe o seu modo de pensar e de viver. Mas, antes de apresentar o capítulo mencionado acima, farei uma radiografia do relato de Grubb.

Retornando ao todo do relato de Grubb, isto é, a sua urdidura, demostramos que a sua construção discursiva parte do fora para o dentro, do longe, das 'histórias de ouvir', para os aspectos essenciais da vida e dos costumes dos lengua-maskóy. Assim, como o relato ainda não está disponível em português brasileiro, disponho os tópicos de sua construção discursiva da seguinte forma, pois julgamos ser importante para que se tenha uma ideia da urdidura da obra. 
Capítulo I: FATOS \& BOATOS: Contrastes - Atrocidades indígenas - Uma raça com chifres - Pigmeus - O Chaco.

Capítulo II: PERIGOS TERRA ADENTRO: exploradores massacrados - Cativos - A busca pela expedição Ibareta - A hostilidade indígena - Temores supersticiosos - Atitude a ser adotada - A hostilidade dos xamãs - Desafio aos poderes dos xamãs.

Capítulo III): NUMA TERRA DESCONHECIDA: Riacho Fernandez - Praga de insetos - O interior - Primeira viagem - Traição dos guias - A primeira aldeia - Signos linguísticos - Ar de autoridade - A vigília noturna - Barganhando para conseguir guias.

Capítulo IV): PRIMEIRAS EXPERIÊNCIAS: Marcha no Paraguai - Na trilha dos saqueadores indígenas - Indenização paga - "Estômago de Jacaré" - Astúcia indígena - Relato de furtos - Incêndio em Neantamana Mudança para Thlagnasinkinmith - Escapando de envenenamento - Insolência - Bebida estrangeira - O olho maligno - Os planos dos xamãs.

Capítulo V): A ORIGEM DOS INDÍGENAS DO CHACO: Padre Lozano - Fugitivos peruanos - O significado da palavra "Chaco" - Parentesco com os Incas - "Cidade dos mortos" - Tesouro escondido - Os Imlah.

Capítulo VI): A VIDA PRIMITIVA DOS INDÍGENAS: Uma aldeia indígena - Abrigos rústicos - Cenário ao pôr-do-sol - Viagens pelo pântano Varíola - O mundo dos espíritos - A vida nômade - Preparativos para a noite - Os cachorros dos indígenas - Os insetos - Métodos de iluminação.

Capítulo VII): ARTE \& INDÚSTRIA: Obstáculos à indústria - A confecção de mantas - Cordas - Preparação das peles - Ornamentos de penas - Colares de conchas de caramujos - Brincos - Cerâmica - Tabaco - Acendendo fogo através de fricção - Cabaças - Instrumentos musicais - Bastões usados como calendários - Armas - Cultivos - Construção de casas.

Capítulo VIII): CAÇA \& PESCA: Habitantes do pântano - Pesca Cobras d'água - Jacarés - Perigos - Caçadas - O jaburu - O avestruz - Os indígenas como imitadores da voz dos animais - O jaguar - Uma aventura.

Capítulo IX): VIAGENS PELO INTERIOR DO CHACO: O primeiro carro de boi - Uma tormenta - Inundações - A travessia de um rio 
- O modo indígena de viajar - Como conseguir água em tempos de seca - A tradição sobre a origem do fogo - A sede - Uma bússola de bolso - Um ato antinatural - Uma festa - Um vendaval de poeira.

Capítulo X): GUERRA: A guerra do Paraguai - Os Lengua e os Kisapang - Causas das guerras entre os indígenas - Preparativos preliminares - Espiões - Estratégias - O ferido - Um relato indígena.

Capítulo XI): RELIGIÃO: A opinião popular - O simbolismo - A criação - $\mathrm{O}$ escaravelho dos egípcios - $\mathrm{A}$ imortalidade da alma - A vida pós-morte.

Capítulo XII): O MUNDO DAS SOMBRAS: Os kilyikhama - Sua aparência e os seus poderes - Os aphangak - Possessão - A alma do falecido Uma experiência misteriosa - A dispersão das cinzas - As almas dos antepassados falecidos - A morada futura da alma - Os espíritos inferiores da criação.

Capítulo XIII): SONHOS: Interpretações - Uma criança doente - As almas no mundo dos sonhos - A influência dos sonhos - Sons noturnos - $\mathrm{Su}-$ perstição - Uma consciência intranquila - Os perigos da alma errante.

Capítulo XIV): SUPERSTIÇÕES: O vento sul - Abscesso na boca e banha - A planta "sensitiva" - Amuletos - Tempestades - A Via-Láctea Redemoinhos - As Plêiades - "Seu avô, o diabo" - Miragens - O arco-íris O espírito do cavalo - Sussurros na floresta - O infanticídio - A superstição e o cristianismo.

Capítulo XV): O XAMÃ \& SEUS OFÍCIOS: O ofício de um xamã - A sua preparação - Hipnotismo - Profecias meteorológicas - Espantando espectros de defuntos - Possuído por um kilyikhama - "Manta azul" - As hemorragias - Expelindo insetos da boca - Espinhas de peixe - Uma epidemia de "agulhas" - Raiz venenosa - Armas de fogo enfeitiçadas - O besouro "bruxo" - Truque da abóbora - Sortilégios - Conhecimentos médicos.

Capítulo XVI): RITOS DE SEPULTAMENTO: Cenas de um enterro - Morrer abandonado - Últimos ritos - Mutilações - Formalidades na sepultura - Uma experiência perigosa em Thlagwakhe - A cerimônia de purificação - O luto - A execução de um assassino - Enterro prematuro.

Capítulo XVII): LIVRANDO UM BEBE DE SER ENTERRADO VIVO: O enterro de uma mulher - Livrando a sua filha de ser enterrada viva - 
Uma situação difícil - O espectro da mãe do bebê - Um banido - Dificuldades para alimentar a criança - Uma longa jornada - A salva.

Capítulo XVIII): AS FESTAS: A Yanmana - A Wairikya - A KyaiyaAs demais festas - Preparativos para uma Kyaiya - A chegada dos convidados - A cantoria - Cerimoniais dos alimentos - Alegria e conversação - Bebedeira - O Maning - Atendimento a uma mulher doente - Efeitos pós-diversão Etiqueta chaquenha.

Capítulo XIX): O SOCIALISMO INDÍGENA: Breve sumário - Imprevidência - Moradias inadequadas - Preguiça - Egoísmo - Sociabilidade - A vida comunitária - Passado e presente.

Capítulo XX): CARACTERÍSTICAS GERAIS: Conservadorismo Humor - Amizade - Confiança - Paciência - Domínio próprio - Coragem - Ciúmes.

Capítulo XXI): MORAL: A embriaguez - A loucura - Falta de veracidade - O escândalo - Estratagema contra estratagema - Honestidade - Reserva - Generosidade - Tristeza - Falta de egoísmo - Cortesia - Leis Matrimoniais - Monogamia - Lassitude ética - Poligamia - Poliandria.

Capítulo XXII): COMO LIDAR COM O INDÍGENA: O indígena, uma criança crescida - A tarefa do missionário - O seu ambiente - Exemplo e preceito - Provas de coragem - Um estratagema ardiloso.

Capítulo XXIII): MESTRE \& DISCÍPULO: A arrogância do recém-chegado - Simpatia - As primícias - Causa e efeito - Independência.

Capítulo XXIV): O INFANTICÍDIO \& OUTROS MALES: As razões do infanticídio - Circunstâncias atenuantes - $\mathrm{O}$ tratamento de uma criança - Waikthla Tingmangyalwa - Enganos - Uma visita inesperada - Tratamento médico - Dificuldades com o idioma - A igreja primitiva.

Capítulo XXV): SOFRENDO UM ATENTADO: Poit - A escolha e a tarefa de um enviado - Apropriações indevidas - Partida para o Oeste - Poit como guia - À procura das vacas - O rio Monte Lindo - Manobras - Flechada disparada pelas costas.

Capítulo XXVI): CORRENDO O RISCO DE SER ENTERRADO VIVO: Extração da flecha - À procura de um caminho transitado - Resgatado 
- Uma noite horrenda - Visitantes - Um mensageiro - Preparativos para um enterro prematuro - Processo lento de recuperação - Notícias de Poit - Suspeitas - Um refrigério bem-vindo - A chegada do grupo de socorro - Natal - Em casa - O medo de um levante - Uma presença pavorosa - No hospital.

Capítulo XXVII): A DEFESA DE POIT \& SEU FIM: A opinião pública - Notícias surpreendentes - A execução - Uma comoção profunda Um resumo - Um sonho - A arma roubada - A história do jaguar - O único defeito do plano de Poit.

Capítulo XXVIII): A LUTA FINAL CONTRA OS XAMÃS: Candidatos ao batismo - Morte por picada de cobra - Complô dos xamãs - Envenenamento - A morte de Andrew - Enfrentando os líderes - O castigo - O discurso de Felipe.

Capítulo XXIX): ENTRE O VELHO E O NOVO: Os efeitos da educação - A etapa de transição - As atrações da civilização - Degeneração parcial.

Capítulo XXX): O CRISTIANISMO CONTRA O PAGANISMO: As condições iniciais - Mudanças notáveis - Fazendas - Comércio - Assentamento - Capacitação industrial - Escola - Hospital - Governo - A igreja Cristã.

Após esta longa descrição da orquestração de cada capítulo e seus subtópicos, que tem como objetivo deixar clara a rota discursiva organizada por Grubb, e também comprovar que essa urdidura mostra a intencionalidade do viajante de mostrar ao leitor o mundo dos lengua-maskóy e, a partir dessa orquestração discursiva, convencê-lo de que tal mundo necessitava da intervenção do "branco", do europeu, do cristão, apresento o capítulo XIX da obra em que Grubb faz a descrição do sistema econômico dos lengua-maskóy. Segue a tradução da parte que tem como título "o socialismo indígena".

\section{O socialismo indígena ${ }^{1}$}

Do pouco que pude reunir da história dos nativos, tenho todos os motivos para acreditar que eram uma raça muito superior - melhor em muitos aspectos do que

1 Todo este capítulo, bem como as citações referentes ao relato de W. Barbrooke Grubb são resultados do processo de tradução empreendido pelos autores deste texto. A partir deste tópico, iniciamos a tradução. 
são agora e que a sua degeneração se deve ao sistema social, pois em seu estado nativo livre, eles são completamente socialistas. Antes de entrar nessa questão, pode ser bastante relevante resumir as características desse sistema, tal como existe entre eles.

A terra pertence ao povo em geral, e nenhum indigena, nem mesmo um chefe, tem direito a alguma reivindicação de qualquer parte de seus companheiros. $\mathrm{Ne-}$ nhum indigena é incentivado a ter mais posses que a de seu vizinho. Seus rebanhos se alimentam do pasto comum, e eles apenas reivindicam suas plantações quando, de fato, a estão cultivando.

Os produtos naturais do país, como caça, mel silvestre, frutas, peixe e lenha são propriedades de todos e a lei nativa exige a maior hospitalidade possivel.

Todo homem deve caçar; não existe tal coisa como uma classe ociosa, nem mesmo entre os chefes. De fato, não há distinções sociais, os chefes apenas mantêm as regras quando é para o bem comum, como em tempos de guerra.

Não existe o direito sucessório. Em grande parte, toda a comunidade é tão responsável pela educação das crianças, quanto os próprios pais; e a educação e o sustento das crianças são questões tribais em vez de ser apenas dos pais. As crianças devem ter tanta liberdade quanto possivel.

Tanto quanto se sabe, há pouca restrição ao casamento nas leis do nativo. Os idosos, os doentes e os deficientes devem ser sustentados pela comunidade.

A competição de um homem que luta para ser superior aos seus semelhantes, para governar outros, ou para melhorar a si mesmo à custa deles, é veementemente combatida e quase não existe.

Quem está viajando e, portanto, impossibilitado de preparar a terra e cuidar de sua roça, ou aqueles que por qualquer outro motivo não tenham como se manter durante algum tempo, tem o direito de reivindicar da comunidade.

Passando desse breve resumo para detalhes mais completos, tento mostrar como pelo menos quatro séculos desse sistema social afetou os indigenas chaquenhos. Existe entre eles tanta diversidade de capacidade, força e energia como há entre outros povos, mas o agricultor capaz que poderia - se assim quisesse - ter uma plantação grande e produtiva por seus próprios esforços, economia e trabalho - e que, portanto, poderia manter sua familia e dependentes confortavelmente - se recusa, em obediência ao regime socialista, a trabalhar para ajudar a sustentar outras pessoas. Assim, ele não produz 
mais do que é absolutamente necessário para as suas necessidades do momento. Ele nunca guarda nada para os tempos de escassez, porque outros não estão fazendo isso, e, portanto, se ele tivesse uma reserva de alimentos, o parcimonioso lhe pediria ajuda e ele teria que compartilhar a comida. O bom caçador consegue abater muita caça, mas ele não vê utilidade em se cansar indevidamente e se satisfaz em suprir as suas necessidades imediatas e as necessidades daqueles a quem ele deseja ajudar.

$O$ resultado natural é que o indígena, ao longo de geraçóes, se tornou um desprovido, preguiçoso e, em grande parte, egoista, e perdeu todos os sentimentos por quem está fora de seu círculo familiar direto.

Alguns exemplos da vida indigena servirão para ilustrar essas afirmações. Certa vez, incitei um indigena forte e capaz para que usasse a terra que ele cultivava para tirar maior proveito. Ele admitiu que o solo era bom e que, comparativamente, com um pouco mais de esforço, poderia triplicar a quantidade de produtos. Também admitiu que sabia bem como preservar o milho e outros produtos e, assim, proteger-se da fome, e até mesmo contra a escassez de alimentos que lhes causa muito sofrimento durante parte considerável do ano. Mas ele argumentou que isso não o beneficiaria se assim o fizesse. Ele mencionou vários membros do seu povo, pediu que eu olhasse para as pequenas plantações e falou: "Se eu cultivar grandes plantações, esses homens vão plantar e cuidar ainda menos de seus plantios e, de acordo com nosso costume, eles se tornariam meus convidados indesejados, e o excedente que eu teria, iria para eles em vez da minha familia. Eu deveria colher minhas colheitas e mantê-las por um periodo de escassez, e esses homens também não economizariam e, sabendo que eu tinha estoque de alimentos, apelariam para mim".

Em outra ocasião, quando caçava com os indígenas, achei um ninho de avestruz com muitos ovos e eles pegaram todos imediatamente. Então falamos: "Por que não deixar alguns ovos no ninho, para que se garanta a reprodução de avestruzes?". Eles riram e disseram: "Se o lobo-guará encontrar o ninho, vai devorar os ovos que deixarmos ou, se outro indigena passar por aqui, ele os levará. Então se sentaram, quebraram os ovos e começaram a engoli-los, comendo uma quantidade totalmente desnecessária e levaram apenas alguns para suas famílias. Isso me pareceu um exemplo de cobiça e egoísmo, mas, naquela noite, ao chegar à aldeia, os caçadores foram cercados rapidamente por várias pessoas que eu sabia que eram muito preguiçosas e 
que naquele dia não tinham feito nada para conseguir alimento. E imediatamente perguntaram aos caçadores o que tinham arranjado e a resposta foi: "Ovos de avestruz". Com olhos ávidos, perguntaram: "Quantos?" "Apenas alguns", foi a resposta; "e o que conseguimos só dar uma refeição para nossas familias". O que não era verdade, e eu lhes disse isso. A resposta foi que muitas daquelas pessoas nunca procurariam comida se pudessem obtê-la de outros, e que não era honroso deixar de suprir as próprias necessidades, lutando pela sobrevivência diariamente diante de todas as adversidades, para dar de comer a quem era tão capaz quanto eles de se esforçar para o seu próprio sustento.

Os indigenas constroem moradias pequenas, apertadas e inadequadas para se abrigar; no entanto, quando empenhados na construção de uma cabana nos moldes nativos para o nosso uso, eles a constroem de modo satisfatório e muito rapidamente. Quando eu os repreendi por não construirem abrigos melhores, responderam: "Se construissemos uma casa grande e espaçosa, quando do mau tempo, outros pediriam hospedagem. Portanto, por que devemos nos esforçar para livrar os outros de seus problemas?

$O$ indigena, frequentemente, mantém sigilo sobre sua reserva de alimentos ou de mel, e chega até mesmo a desperdiçar, simplesmente porque não concorda em compartilhar com quem ele não gosta.

Esse socialismo diminuiu e atrofiou todos os hábitos comuns do povo. Um homem que insistisse em guardar para si e para sua familia os bens que ele ganhou por seu próprio esforço, seria odiado e ameaçado pelos demais. Um homem sequer guardará dois cobertores - para uma eventualidade - porque um homem que não possui ovelhas, ou tenha se casado com uma esposa preguiçosa que não quer tecer, vai incomodá-lo para emprestar seu cobertor sobressalente, e, geralmente, o cobertor vai parar nas mãos desse homem. Portanto, ele prefere negociá-lo - assim que haja uma oportunidade - por algo que ele possa usufruir por certo tempo.

Geralmente, o indigena ama os filhos e supre as suas necessidades com generosidade. Ele é gentil com seus parentes e amigos; e o visitante casual, observando as pessoas compartilhando o alimento, aparentemente com grande generosidade, pode pensar que eles são excepcionalmente liberais e generosos. Mas essa aparente hospitalidade é dada de má vontade, embora aparentemente de boa graça. De acordo com a lei, eles são obrigados a compartilhar. Esse sistema leva não apenas 
à pobreza e à parcimônia, mas também ao crime. Os idosos são frequentemente negligenciados, não tanto intencionalmente, mas por causa da extrema pobreza em que as pessoas vivem e do egoismo de muitos que insistem em compartilhar o alimento em vez de esforçar-se para aumentar a oferta.

Para os indígenas, o socialismo não é uma questão de escolha, pois são submetidos por causa das circunstâncias. A natureza do país, devido à falta de meios para melhorá-lo, os força a levarem uma vida nômade e, portanto, até o presente momento, não havia necessidade de reivindicar direitos sobre a terra. Mais uma vez, a história dessas pessoas prova que eles adentraram essa planície inóspita devido às forças sobre as quais não tinham controle, a principal delas era a pressão que sofriam das nações mais fortes.

Pressionado por essas forças, enfrentando a oposição daqueles que já tinham ocupado as terras mais baixas, foram obrigados a lutar pela própria vida. Todo homem era importante na guerra, mesmo que preguiçoso e um peso para os outros em tempos de paz. Era impossivel viver entre individuos que não fossem do seu próprio povo. A vida seria insuportável em tal terra, destituido dos seus irmãos e, portanto, da comunhão. Para o indígena, seria insuportável viver a vida individualizada que os colonos vivem nos assentamentos, porque o indígena é, essencialmente, um ser sociável e deleita-se com a companhia dos seus. A frição e a contrariedade impostas num assentamento seriam insuportáveis e como já tinham levado a vida em comum nos perigosos tempos primórdios, quando era preciso que todos compartilhassem de tudo, subsequentemente, seria difícil introduzir mudanças que podiam levá-los à desintegração.

$\mathrm{Se}$, algum dia, vamos conseguir elevar essas pessoas acima do baixo nivel em que as encontramos, achamos absolutamente necessário opor-se a esse sistema social e, conhecendo o conservadorismo inato dos indigenas, ficamos surpresos ao descobrir quão prontamente aceitaram a modificação. De fato, antes de chegarmos ao interior do Chaco, as pessoas estabelecidas na terra, e, em certa medida, longe dos perigos da guerra, já tinham começado a se dividir em núcleos familiares menores do que antigamente. Novos grupos tinham se formado, compostos principalmente por parentes próximos, $e$ tinham propriedades já adquiridas. Também descobrimos que tinham, de modo limitado, começado a tornar as coisas mais difíceis para os preguiçosos e para quem não produzia o seu próprio sustento; também que se opunham fortemente a qualquer proposta de casamento entre suas mulheres e homens conhecidos como preguiçosos. 
Já que o homem não ia trabalhar para cercar-se de bens, posto que o que ele conseguisse seria repartido com outros, começamos a tentar inculcar-lhes a ideia de garantir os direitos daqueles que adquiriram bens honestamente. Contamos com o apoio imediato dos indígenas, e, nesses poucos anos, ocorreu uma grande mudança. $O$ sistema comunal está desaparecendo rapidamente, e as pessoas se erguendo na escala social e saindo da barbárie muito rapidamente também. Inculcamos a necessidade absoluta dos parentes apoiarem os parentes e dos pais assumirem inteiramente o cuidado de seus filhos, antes de buscar ajuda da comunidade.

Nosso objetivo tem sido torná-los um povo forte e independente, não uma nação de indigentes. Para a honra do indígena - épreciso que seja dito - depois de quatro séculos desse sistema degenerativo de dependência dos outros, ele tem muito em seu caráter de genuina generosidade e bondade, e, mediante uma oportunidade justa, ele ainda tem bastante independência e autoconfiança. Desde que uma completa revolução social ocorreu entre essas pessoas nos últimos vinte anos, não mais as encontramos vivendo num sistema comunista, mas como trabalhadores independentes, acumulando bens por meio de seus próprios esforços, e respondendo com alegria e entusiasmo ao chamado da civilização cristã.

Com os parcos recursos à sua disposição, eles contribuem com os dispêndios de sua escola e hospital e com a subsistência dos doentes e dos pobres que não têm parentes para apoiá-los. Eles ainda administram suas próprias leis - que os governam - embora sob a nossa orientação, mas nenbuma ajuda de qualquer tipo é dada indiscriminadamente, seja por eles ou por nós, onde quer que seja que deva ser evitada.

Tomemos, como exemplo, uma comunidade de cerca de cem pessoas. Quinze anos atrás, a única coisa que possuíam eram suas armas, alguns utensilios domésticos miseráveis e algumas ovelhas, cabras e cavalos; e levando-se em consideração que hoje a comunidade possui uma riqueza agregada no valor de cerca de $£ 1.000$ [mil libras], em rebanhos e manadas, mercadorias, casas e plantações permanentes, para não mencionar uma soma considerável de dinheiro em poupança em banco próprio. Três nativos possuem suas próprias lojas comerciais, enquanto muitos outros são comerciantes itinerantes. A igreja é mantida quase que inteiramente às custas deles e contribuíram com uma soma considerável para a sua construção. O principio que ensinamos e fora aceito é que, na vida, cada um - homem e mulher - deve prover suas próprias necessidades; também 
devem exercitar a generosidade e a caridade voluntariamente, suprindo suas próprias necessidades primeiro e depois ajudando os outros como pudessem. Mas, felizmente, não há grande necessidade de praticarem a caridade, pois o país pode mantê-los facilmente, se eles tão somente se esforçarem para isso. É por essa razão que os principios de autossustento e independência de caráter lhes foram inculcados, e agora devem confiar principalmente em si mesmos no governo de seu destino.

A partir da tradução feita, salientamos que, para não reproduzir a violência etnográfica cometida por Grubb em sua leitura da cultura dos lengua-maskóy, convém que o leitor não sinta pena dos nativos, muito menos imagine que a sua própria cultura seja superior à deles e que, portanto, o missionário tinha tão somente a intenção de cristianizá-los. É preciso, antes de qualquer emissão de juízo de valor, que se procure refletir sobre essas formas de vida e de pensar dos nativos como ações e formas políticas apropriadas ao meio em que viviam e em completa relação de harmonia com a Natureza; é preciso que afastar-se da ideia de miserabilidade impingida sobre esses povos, da ideia de que tais nativos viviam a maior parte de suas vidas em busca de alimentos e, claro, de trabalho. Como questiona Clastres em $A$ sociedade contra o Estado,

por que razão os homens dessas sociedades quereriam trabalhar e produzir mais, quando três ou quatro horas diárias de atividade são suficientes para garantir as necessidades do grupo? De que lhes serviria isso? Qual seria a utilidade dos excedentes assim acumulados? Qual seria o destino desses excedentes? É sempre pela força que os homens trabalham além de suas necessidades (Clastres, 2020. p. 171).

Em Grubb, no entanto, está implícita a ideia de sobretrabalho ao nativo. Pode-se comprovar isso a partir das palavras do próprio missionário. "Hoje" - diz Grubb -

a comunidade possui uma riqueza agregada no valor de cerca de $£ 1.000$ [mil libras], em rebanhos e manadas, mercadorias, casas e plantações permanentes, para não mencionar uma soma considerável de dinheiro em poupança em banco próprio. Três nativos possuem suas próprias lojas comerciais, enquanto muitos outros são comerciantes itinerantes. A igreja é 
mantida quase que inteiramente às custas deles e contribuíram com uma soma considerável para a sua construção (Grubb, 1911).

Essa imposição ao trabalho para além das necessidades dessas sociedades indígenas inculcou em nosso imaginário a ideia de que o nativo é preguiçoso nato e, assim, precisaria da intervenção do Estado enquanto forma centralizada de poder de onde emana toda a lei, em especial a que destrói a sociedade vista como primitiva, pois o Estado possui a potência de sujeitar e coagir toda a sociedade [com exceção da oligarquia dominante] a favor de quem ocupa o poder político. Trabalhar sem cessar, é a lei. Nada de 'adubação da mente' - como diria Bacon - de lazer, de tempo gasto com reflexões acerca da vida. Não deve haver tempo para se pensar no próprio caminho, no próprio viver, no percurso da viagem terrena.

Apesar de todas as premissas grubbiana de cunho negativo acerca do mundo lengua-maskóy, o seu relato é uma fonte valiosa de informações geográficas, linguísticas, etc., porque nos possibilita reflexões outras - isto é reflexões pautadas em outras concepções de mundo que não as advindas de escritores europeus que, em muitas 'outrizações', tentam perpetuar a imagem negativa dos povos nativos. Essas assertivas negacionistas pululam na obra de Grubb e tornam-se um campo de investigação e re-tradução ou des-tradução dessas mesmas assertivas. A fidelidade, apregoada por muitos teóricos e críticos de tradução, não deve ser vista e - aguardada pelo leitor - tão somente nas escolhas linguísticas do sujeito tradutor, mas principalmente à cultura que fora etnografada de modo pejorativo. Cabe a esse sujeito tradutor a tarefa, se possível, de pensar, refletir e buscar aplicar em muitas partes da tradução um juízo não negacionista no processo tradutório. Isso não seria deturpar o pensamento do autor/tradutor culturalista, mas posicionar-se criticamente quando assim julgar necessário. Afirmar que os nativos vivem em completa desorganização social é um insulto e demonstração de incompreensão dessas sociedades sul-americanas; um exercício colonialista que mostra muito mais da cultura desse viajante do que da cultura viajada/etnografada. 


\section{Referências}

CAMPOS, Sheila, P. P; CARVALHO, Fábio. A e FERNANDES, Maria Luiza (organizadores). Sobre viagens, viajantes e representaçôes da Amazônia. Boa Vista: Editora da UFRR, 2020.

CLASTRES, Pierre. A sociedade contra o Estado. Trad. Theo Santiago. São Paulo: Ubu Editora, 2020.

GRUBB, W. B. An unknown people in an unknown land. London: Seeley \& Co. Limited, 1911. 


\section{CAPÍTULO 11. PORTUGUÊS PARA IMIGRANTES: REFLE- XÕES NO CONTEXTO DA COVID-19}

Odete Burgeile

Djenane Alves dos Santos

Renata Aparecida lanesko

\section{Introdução}

Diante de uma pandemia que assola o mundo, ceifando milhares de vidas, somos levados a pensar e repensar nosso papel como indivíduos e também como instituição de que fazemos parte. $\mathrm{O}$ que fazer para minimizar os efeitos destruidores desta onda avassaladora? Estas questões requerem respostas para além do pensar e teorizar e com ação imediata.

O presente trabalho ocorreu como consequência das atividades realizadas com um grupo de alunos do programa Trânsitos, fronteiras, migração e línguas adicionais na Amazônia, vinculado ao Departamento de Línguas Estrangeiras e do Grupo de estudos linguísticos, literários e socioculturais (GELLSO), da Fundação Universidade Federal de Rondônia, e tem como objetivo geral promover ações que articulem ensino, pesquisa e extensão através da ministração de cursos de línguas adicionais, preparação para o ENEM e Exames de Proficiência, oficinas, auxílio na elaboração de currículos e serviços de tradução, de forma a beneficiar a comunidade acadêmica no aprofundamento teórico e aperfeiçoamento pedagógico, e também, ajudar a comunidade externa com oportunidades de aquisição e aperfeiçoamento de habilidades na área de línguas adicionais, ampliando as oportunidades de inserção sociocultural, econômica e educacional na sociedade brasileira. Além disso, o programa oferece aos alunos dos cursos de Letras do Departamento de Línguas Estrangeiras oportunidade para desenvolver práticas de ensino, transpondo o espaço de formação para além da universidade e, desta forma, promover pesquisas resultantes de reflexões sobre suas práticas docentes. Essa proposta abrange os alunos dos cursos de Letras Es- 
panhol/Inglês, atuando no ensino, e os imigrantes que receberão os cursos, numa dinâmica que desenvolve o ensino, a pesquisa e a extensão.

Há no programa o curso de Português como Língua Adicional para falantes de outras línguas cuja ementa consiste de atividades para compreensão auditiva, produção oral, leitura e escrita de língua portuguesa em nível básico, intermediário e avançado. O conjunto de conteúdos da ementa do curso inclui gêneros textuais diversos com temas de questões ambientais, de direitos humanos, de linguística, de intercultura, de identidade e de gênero, assim como noções de estruturas fonético-fonológicas do português.

A avaliação dos cursistas se realiza de forma continuada, com exercícios escritos para fixação, atividades que envolvem a compreensão auditiva e a expressão oral. Para receber os certificados de 60 horas, o cursista deve ter uma participação de 75\% nas atividades realizadas e o mínimo de 60 pontos na média das avaliações. O curso havia iniciado em outubro e quando adveio a crise do coronavírus, estivemos diante de um grande desafio: o de adequar o programa para continuar atendendo a este público e não somente isso, como continuar assegurando o direito à aprendizagem de estudantes vulneráveis em um contexto adverso.

Assim, neste trabalho, temos o objetivo de destacar as ações do curso que envolveram o trabalho com as fake news, cuja amostragem abarca os temas transversais como saúde, ética e cidadania, visando conscientizar os alunos e, assim, minimizar a propagação do coronavírus por meio da identificação de informações falsas e reflexão sobre suas consequências, bem como acesso e compartilhamento de informação verdadeiras sobre o vírus, uma vez que o acesso a informações pertinentes leva a população à prevenção adequada e eficiente. Objetiva-se também destacar as ações sociais que visaram minimizar o impacto da pandemia entre o grupo mais vulnerável da comunidade dos imigrantes. Além disso, trazemos reflexões sobre efeitos sociais, causados pelo sistema econômico vigente dentro do contexto da pandemia da COVID-19.

Para tanto utilizamos o aporte teórico dos temas transversais (PCNs, 1998; BNCC, 2017; Araújo, 2003), das consequências das fake news (Sales, 2020) e efeitos sociais da COVID19 (Harvey, 2020; Davis, 2020). A pesquisa 
se enquadra na pesquisa-ação, pois possibilita aos pesquisadores a investigação de sua própria prática. Assim, neste trabalho, a finalidade é informar sobre as ações que estão sendo realizadas no curso, tendo como objetivo levar a possíveis reflexões sociais e didático-pedagógicas referentes ao ensino de Português como Língua Adicional.

\section{COVID-19: A PANDEMIA DO SÉCULO}

Sem dúvidas, a pandemia provocada pela COVID-19 mexeu com a rotina de todos. Indivíduos, família e instituições, todos tivemos que nos adaptar bruscamente a um contexto de situações novas. Mas há de se pensar que para os que possuem condições financeiras certamente essas adaptações ocasionaram incômodos menores e talvez as mudanças sejam aceitas em nome da prevenção e proteção. Mas, o que dizer daqueles que não podem ter o mesmo acesso a um contexto de prevenção e proteção?

De acordo com Davis (2020), aqueles que podem pagar bons planos de saúde e que seguem prudentemente as recomendações, podem trabalhar e ensinar de casa confortavelmente isolados. "Enquanto isso, milhões de trabalhadores com baixos salários, trabalhadores rurais, desempregados e sem teto estão sendo jogados aos lobos" (Davis, 2020, p. 8). Essa é a dura realidade de uma crise desigual que expõe a fragilidade do sistema em sentido macro e micro.

Ainda segundo Davis (2020), o sistema econômico vigente torna a situação da crise epidêmica ainda pior. Segundo o autor, desde o ano 2000, nos Estados Unidos, os cuidados com a saúde apresentam repetidas falhas. São anos de cortes na capacidade de internação para fins lucrativos. A medicina de emergência continuou a ser reduzida e os recursos estaduais e federais receberam cortes no orçamento destinados ao setor. Atualmente, a situação só piorou com a contínua redução nos orçamentos destinados à saúde, desinvestimento na preparação médica de emergência, o que levou à inevitável falta de suprimentos básicos de baixa tecnologia, respiradores e leitos de emergência. Além disso, estoques nacionais e regionais muito abaixo do indicado pelos modelos epidêmicos, escassez de equipamentos de proteção para os trabalhadores da saúde, junto ao desastre 
com o kit de teste, são mostras da ganância para manter o sistema com fins lucrativos em detrimento da saúde da população. Somos sabedores de que este quadro não destoa da situação do setor da saúde no Brasil.

Outro problema que se tornou evidente por razão da epidemia ocasionada pelo COVID-19 foi o aumento da divisão de classes (Davis, 2020). Quase metade da força de trabalho nos Estados Unidos não pôde entrar em quarentena "e é praticamente obrigada a transmitir a infecção ou ficar com o prato vazio" (Davis, 2020, p. 9). No Brasil, os trabalhadores assalariados que trabalharam nos setores ligados a alimentos, saúde, segurança e outros serviços essenciais não puderam ficar em isolamento. Segundo estatísticas do Instituto Brasileiro de Geografia e Estatística (IBGE) publicadas em janeiro de 2020, os trabalhadores informais representam $41,4 \%$ do mercado de trabalho. Esses trabalhadores dependem do movimento do comércio e, muitas vezes, têm que optar entre sustentar suas famílias ou seguir as recomendações da OMS de isolamento.

De acordo com Harvey (2020, p. 21),

Esta "nova classe trabalhadora" está na vanguarda e suporta o peso de ser a força de trabalho que corre maior risco de contrair o vírus através de seus empregos ou de ser demitida injustamente por causa da retração econômica imposta pelo vírus. Há, por exemplo, a questão de quem pode e quem não pode trabalhar em casa. Isto agrava a divisão social, assim como a questão de quem pode se isolar ou ficar em quarentena (com ou sem remuneração) em caso de contato ou infecção.

Essa realidade expõe uma fragilidade que emana das diferenças de classes sociais e dos impactos que elas demandam. Nesse contexto, quem tem direito à proteção e à saúde? Esta mesma realidade demonstra que os impactos recaem sobre a classe menos favorecida, empurrada a enfrentar os riscos com a intenção de subsistência.

Dessa forma, a transmissão viral avança muito. Harvey (2020) explica que variam muito as condições que contribuem para a transmissão rápida através dos corpos hospedeiros "a forma como os seres humanos interagem uns 
com os outros, se movem, se disciplinam ou se esquecem de lavar as mãos afeta a forma como as doenças são transmitidas” (Harvey, 2020, p. 15).

$\mathrm{O}$ autor defende ainda que, no caso da COVID-19, "o impacto econômico e demográfico da disseminação do vírus depende de fissuras e vulnerabilidades preexistentes no modelo econômico hegemônico" (Harvey, 2020, p. 15). Mas o que difere as crises epidêmicas passadas da atual, segundo o mesmo autor, é que agora os efeitos econômicos no mundo estão fora de controle. Em longo prazo é possível que se encurte ou se diversifique a cadeia de abastecimento e avanço para formas de produção menos intensivas em mão de obra. Isso implica em cortes e demissões de trabalhadores, o que diminui a procura final, a procura de matérias-primas e, consequentemente, o consumo produtivo. Assim, modos de consumo caíram de forma devastadoras, como o setor de viagens, turismo, restaurantes, hotéis, eventos, por exemplo. (Harvey, 2020)

Sobre isso, Harvey (2020, p. 20) também diz que:

Este local de acumulação de capital está morto: as companhias aéreas estão perto da falência, os hotéis estão vazios e o desemprego em massa no setor hoteleiro é iminente. Comer fora não é uma boa ideia e os restaurantes e bares fecharam em muitos lugares. Até mesmo entregas a domicílio parece arriscado. $\mathrm{O}$ vasto exército de trabalhadores uberizados ou em outras formas de trabalho precário está sendo dispensado sem nenhum meio visível de apoio. Eventos como festivais culturais, torneios de futebol e basquete, concertos, convenções empresariais e profissionais, e até reuniões políticas em torno de eleições foram cancelados. Estas formas de "consumismo experiencial baseado em eventos" foram extintas. A renda dos governos locais foi devastada.

Esse quadro é preocupante, pois representa uma ameaça aos grupos vulneráveis e demonstra a crueldade e insustentabilidade do sistema econômico vigente.

Além dos problemas descritos, a esse contexto, soma-se o papel das redes sociais que demonstraram ser um lugar de disseminação não somente de ideologia dominante para a aceitação mórbida de que "tudo ocorre naturalmente", mas também das fake nerws sobre o vírus, que causaram prejuízos sem precedentes à sociedade. 


\subsection{FAKE NEWS E SUAS CONSEQUÊNCIAS}

As fake news ganharam atualmente grande repercussão devido à velocidade de alcance que lhes dá a internet por meio de sites e redes sociais, mas as informações falsas, mentiras e difamações sempre existiram e talvez nunca foi um assunto notório como tem sido hoje, chegando a serem consideradas como indústria para fins econômicos e políticos. A publicação amplificada de informações falsas pela internet pode trazer profundos prejuízos aos indivíduos como também grandes danos à sociedade.

Sales (2020) diz que a desorientação causada pela disseminação de fake news se torna especialmente grave quando falta uma compreensão do quadro pandêmico e das medidas de enfrentamento no contexto vivido em decorrência do novo coronavírus e do esgarçamento dos sistemas de saúde. Diz também que a popularização dos smartphones e o uso das redes sociais intensificaram esse fenômeno.

A fim de verificar as trágicas consequências da ampla disseminação das fakes news em sites e redes sociais, vamos elencar alguns destes acontecimentos que foram relatados em revistas e sites brasileiros. Alguns destes relatos têm implicações diretas com o uso de informações falsas sobre a COVID-19.

A revista Hipercultura ${ }^{1}$ publicou uma matéria sobre as fakes news, na qual relata as cinco que tiveram consequências trágicas. A primeira se refere ao caso ocorrido em São Paulo da Escola de Educação Infantil Base, em que duas mães ao suspeitarem que seus filhos sofriam abusos sexuais prestaram queixa na delegacia e passaram a mobilizar a imprensa. Manchetes sensacionalistas veicularam informações tendenciosas e o resultado ocasionado foi de danos morais e financeiros aos donos e funcionários da escola, pois passaram a receber ameaças de morte. Além disso, a casa dos donos foi pichada com acusações de pedofilia, a escola foi fechada e os funcionários perderam seus empregos. Após as investigações, comprovou-se a inocência de todos os acusados.

O segundo caso destacado pela revista foi o de uma mulher linchada pela população em Guarujá. Isso ocorreu após um administrador de uma página do

1 Para mais informações: <https://www.hipercultura.com/fake-news-consequencias-tragicas/> Acesso em: 15 jun 2020. 
Facebook publicar que uma mulher estaria sequestrando crianças nesta cidade. Depois de dois dias do linchamento, a mulher veio a falecer. Em consequência a este crime, foi criada a Lei 7544/14, que prevê multa e detenção para pessoas que incitem a violência na internet. A terceira fake relatada se refere ao linchamento de dois homens no México, também relacionada ao rapto de crianças. $\mathrm{O}$ caso se deu devido à propagação de boato pelo Whats $A p p$, um estudante de Direito e seu tio, agricultor, foram acusados por populares na rua, foram detidos por policiais e, ao serem liberados, foram espancados e queimados vivos pela multidão que se aglomerou fora da delegacia. A quarta fake com consequências trágicas também é um caso de linchamento de pessoas por acusação falsa de sequestro infantil, veiculada nas redes sociais, episódio ocorrido na Índia, onde 7 pessoas foram agredidas até a morte. A quinta e última relata um problema de saúde pública como consequência de fakes nerws. A revista relata que a desinformação pode ser uma ameaça à saúde da população que se evidenciou em 2018 quando o Brasil enfrentou um surto de febre amarela porque a vacina que combate a doença foi alvo de notícias falsas nas redes sociais.

Em situação de pandemia, a veiculação de fake nerws em sites e redes sociais podem trazer graves consequências. Além da situação catastrófica que o vírus pode trazer ao mundo, essa condição tende a se agravar com a desinformação. A BBC News, em 17/06/2020, publicou uma matéria com o seguinte título "Um menino de 5 anos que ficou cego e outros efeitos trágicos das informações falsas sobre a covid-19”2. A equipe de reportagem procurou por relatos de pessoas afetadas e depoimentos de especialistas da área da saúde, assim como evidências de fakes newws para encontrar relações entre a propagação de notícias falsas e acontecimentos de ataques, incêndios, envenenamentos e mortes pelo mundo. Essa equipe investigou o grande perigo da desinformação a partir de dezenas de casos.

Segundo a revista, nos Estados Unidos um casal pensou que as notícias sobre o vírus não passavam de engano após ler teorias conspiratórias na internet, por isso não seguiram as regras e nem procuraram ajuda quando começaram a sentir os primeiros sintomas. Do hospital, Brian de 46 anos relatou à

2 Para mais informações, acessar: <https://www.msn.com/pt-br/noticias/mundo/um-menino-de-5-anos-que-ficou-cego-e-outros-efeitos-trágicos-das-informações-falsas-sobre-a-covid-19/ar-BB15yOcd?li=AAggXC1 1/> Acesso em: 16 mai 2020. 
revista que sua esposa estava em estado grave, sedada e com um respirador, seus pulmões estavam inflamados e o corpo não respondia ao tratamento.

A reportagem abordou também as declarações feitas pelo presidente Donald Trump. Algumas delas foram especulações sobre o uso de hidroxicloroquina, cura por produtos de limpeza, neutralização do vírus por raios ultravioleta. Essas declarações resultaram em danos à saúde de muitas pessoas, como por exemplo, casos de ingestão de sabão líquido desinfetante que pode trazer consequências em longo prazo como câncer e sangramento gastrointestinal. Em uma ocorrência mais grave, Gary Lenius e sua esposa Wanda ingeriram um produto de limpeza que continha uma substância venenosa e, em poucos minutos, sentiram tontura e calor, tiveram vômitos e dificuldade para respirar. Gary veio a óbito e sua esposa ficou hospitalizada.

A BBC explicou que sem o aval das autoridades de saúde, o uso da hidroxicloroquina foi mencionado por figuras influentes como o presidente Jair Bolsonaro e o executivo-chefe da Tesla, Elon Musk, além do já mencionado líder americano. As repercussões pelo mundo foram várias. $\mathrm{Na}$ Nigéria, as autoridades de saúde alertaram a população contra o uso da hidroxicloroquina após o aumento do número de pessoas envenenadas por essa substância. Um vietnamita de 43 anos, após ingerir uma dose alta dessa substância, deu entrada em uma clínica especializada em envenenamento, apresentou sintomas de vermelhidão, tremor e incapacidade de enxergar. Sobre a ação da Organização Mundial da Saúde em relação à hidroxicloroquina, a BBC menciona:

Nos últimos dias, a Organização Mundial da Saúde (OMS) decidiu retirar temporariamente a hidroxicloroquina da sua lista de medicamentos em estudo para tratar a covid-19. Com base em um estudo publicado na Lancet, a instituição alegou que não estava claro que o medicamento apresentava o nível de segurança necessário. Mas o estudo em questão sofreu diversos questionamentos sobre a confiabilidade dos dados e foi retirado da plataforma. Em seguida, a OMS decidiu retomar os estudos com a droga.

Desta forma, percebe-se que a necessidade de pesquisas e estudos eficientes são importantes antes de veicular informações e as autoridades governamentais precisam ter muito cuidado com as declarações que fazem publicamente. 
Segundo a BBC, no Irã as autoridades confirmaram mortes de centenas de pessoas por envenenamento causado pela ingestão de álcool contaminado após a viralização de boatos que incentivavam seu uso para efeitos terapêuticos contra a COVID-19. Uma criança de 5 anos ficou cega depois que seus pais a fizeram ingerir álcool para combater a doença. Foram aproximadamente 796 pessoas afetadas até o fim de abril.

Outro caso relatado pela $\mathrm{BBC}$ foi o de ataques às torres de transmissão de telefonia celular na Índia depois de boatos espalhados na internet. No Reino Unido, mais de 70 torres de transmissão de telefonia celular foram atacadas por causa de boatos veiculados de que a tecnologia $5 \mathrm{G}$ de comunicação móvel seria responsável pela propagação do novo coronavírus.

$\mathrm{Na}$ mesma reportagem, a $\mathrm{BBC}$ continua com relatos de ataques violentos a chineses, asiáticos e muçulmanos e tensões raciais entre etnias, após a disseminação de notícias falsas. Alguns deles são:

Em abril, três muçulmanos foram atacados violentamente em incidentes separados em Nova Déli, na Índia. Segundo a polícia, eles foram agredidos depois que passaram a circular rumores de que muçulmanos estavam disseminando o vírus. Em Sisai, uma pequena vila no leste da Índia, gangues rivais se confrontaram. Isso ocorreu após um ataque a um garoto muçulmano, novamente uma ação associada aos falsos rumores. Um jovem perdeu a vida e outro ficou seriamente ferido. Informações falsas também circularam entre comunidades étnicas. Em Bradford, na Inglaterra, boatos afirmavam que pacientes não brancos estavam sendo abandonados à morte.

Seguramente esses e outros relatos de ataques a grupos e rumores que responsabilizam grupos étnicos pintam um quadro grotesco e representam o grande grau de ignorância e desinformação a que a sociedade pode chegar. Os efeitos da veiculação de fake news se espalham pelo mundo e causam enormes prejuízos sem precedentes à humanidade. 


\subsection{TEMAS TRANSVERSAIS E ENSINO DE LÍNGUAS ADICIONAIS}

Conforme exposto até aqui, vimos como os problemas oriundos da pandemia, causados pelo novo coronavírus, afetam de forma direta os grupos sociais mais vulneráveis, devido às desigualdades sociais existentes no sistema econômico vigente. Vimos também como o contexto de pandemia pode se agravar com a disseminação de notícias falsas em sites e redes sociais. Com isto, passaremos a discorrer sobre a importância dos temas transversais, para mais adiante trazer reflexões sobre a importância do trabalho com estes temas, dado o contexto desta crise atual.

O processo de ensino-aprendizagem de línguas, através dos temas transversais, constitui um meio de aproximar o aluno de sua realidade e desenvolver sua capacidade de visão crítica diante do mundo e assim motivar a aprendizagem.

Os Parâmetros Curriculares Nacionais PCNs (1998) como diretrizes, cujo objetivo é orientar os professores, apresentando normatização de aspectos fundamentais em relação às disciplinas, apresentaram os temas transversais como proposta a ser inserida no processo de ensino e aprendizagem de línguas. Conforme esses documentos, os temas transversais “[...] correspondem a questões importantes, urgentes e presentes sob várias formas na vida cotidiana”, tais como ética, saúde, meio ambiente, orientação sexual, pluralidade cultural, trabalho e consumo (BRASIL, 1998, p. 17).

A Base Nacional Comum Curricular - BNCC, como documento que define os conhecimentos essenciais para os estudantes da Educação Básica, mais recentemente, trouxe uma nova terminologia para os temas transversais, são os temas de relevância social, chamados de "temas contemporâneos". Segundo a BNCC, esses temas envolvem a vida humana em escala social, local e global (BRASIL, 2017). Ainda de acordo com a BNCC (BRASIL, 2017, p. 13), esses temas devem ser integrados às propostas de ensino de modo transversal.

Os PCNs (BRASIL, 1998) enfatizam que os temas transversais trazem à sala de aula as questões sociais que estão sendo vivenciadas pela sociedade em seu dia a dia e devido a se tratar de temas complexos, nenhum componente 
curricular deve trabalhar com eles de maneira isolada, pois nenhum componente curricular é suficiente para explicá-los.

Deste modo, os temas transversais abarcam as diversas áreas de conhecimento, propiciando uma aprendizagem interdisciplinar, além de enfatizar a importância das relações interpessoais no contexto sociocultural e possibilitar a compreensão da realidade.

Sanches Pérez (1997) afirma que determinados tipos de atividades em sala de aula podem propiciar a motivação e despertar o interesse em aprender. Contudo, os alunos nem sempre estão motivados. Uma forma para se contornar esta situação é que o educador aprenda e domine as técnicas necessárias para utilizar essas estratégias e busque o melhor meio para despertar o interesse dos alunos para assim transmitir o conhecimento.

Desta maneira, não há dúvida que o trabalho com os temas transversais constitui-se como instrumento de motivação, pois o interesse é despertado quando o aluno está vivenciando o assunto tratado na aula, o qual é também de interesse dele e faz parte de sua realidade.

Sobre a eleição de conteúdos, os Parâmetros Curriculares Nacionais apontam que:

A eleição de conteúdos, por exemplo, ao incluir questões que possibilitem a compreensão e a crítica da realidade, ao invés de tratá-los como dados abstratos a serem aprendidos apenas para "passar de ano", oferece aos alunos a oportunidade de se apropriarem deles como instrumentos para refletir e mudar sua própria vida. Por outro lado, o modo como se dá o ensino e a aprendizagem, isto é, as opções didáticas, os métodos, a organização e o âmbito das atividades, a organização do tempo e do espaço que conformam a experiência educativa, ensinam valores, atitudes, conceitos e práticas sociais. Por meio deles pode-se favorecer em maior ou menor medida o desenvolvimento da autonomia e o aprendizado da cooperação e da participação social (Brasil, 1997, P. 23 E 24).

Assim, os temas transversais influenciam de modo significativo no processo de ensino e aprendizagem de línguas adicionais, determinando a importância da conscientização e da valorização do contexto social para essa aprendizagem.

De acordo com Araújo (2003, p. 28), transversalidade consiste em: 
[...] temáticas que atravessam, que perpassam, os diferentes campos do conhecimento, como se estivessem em uma outra dimensão. Tais temáticas, no entanto, devem estar atreladas à melhoria da sociedade e da humanidade e, por isso, abarcam temas e conflitos vividos pelas pessoas em seu dia-a-dia.

Como vimos, os temas transversais se aproximam da realidade do aluno e oportunizam o debate de questões sociais que estão sendo vivenciadas por eles, propiciando reflexões que colaboram para uma aprendizagem significativa para a vida em contexto autêntico.

Para Moreno (1998) a ideia de transversalidade contribui para dar significado à aprendizagem e para inserir o aprendiz no contexto sociocultural em que se encontra, assim como no contexto de uma nova cultura, pois assim a realidade educativa da escola está determinada pelas necessidades mais urgentes de alunos e alunas e do ambiente sociocultural de onde eles provêm.

Deste modo, a proposta da transversalidade para a inserção em uma nova cultura e em novas realidades contribui para atender necessidades de imigrantes que se estabelecem no Brasil e precisam de uma inserção cultural e social, essa constitui uma de suas necessidades mais urgentes.

Portanto, os professores de línguas adicionais devem atentar para as necessidades dos alunos, oferecendo-lhes um ensino contextualizado para promover uma aprendizagem significativa.

A proposta dos temas do cotidiano baseia-se no conceito de que o ser humano necessita exercer sua cidadania, vivenciando a prática de relacionar-se com o outro, aceitar e conviver com as diferenças socioculturais, seja dentro de sua própria cultura ou inserido em outra cultura, possibilitando ampliar sua visão de mundo.

Do mesmo modo, a proposta de temas como saúde, ética e cidadania dentro do contexto da pandemia ocasionada pelo novo coronavírus, baseia-se no conceito de que o aluno necessita exercer o direito a reflexões críticas sobre as implicações que envolvem esse assunto.

\subsection{RELATO DA EXPERIÊNCIA}

No início do ano de 2020, retomamos as aulas referentes ao curso Português como Língua Adicional para falantes de outras línguas de forma 
presencial, conforme o previsto. No entanto, em meados do mês de março, a pandemia ocasionada pela COVID-19 trouxe preocupação às autoridades governamentais no âmbito nacional e regional e a ameaça de um aumento exponencial de casos ocasionados pela COVID-19 causou a suspensão do calendário e de todas as atividades presenciais da Fundação Universidade Federal de Rondônia, assim como das outras universidades públicas e privadas do país. A partir desse momento, informamos aos alunos sobre as necessidades de suspensão das aulas, o que os deixou preocupados, visto que o aprendizado da língua portuguesa representa, além do conhecimento linguístico, inserção social e a possibilidade de obter um trabalho.

Esta nova realidade nos fez pensar em nosso papel como educadores e como instituição diante de problemas e desafios que precisavam ser superados. Assim, buscamos alternativas que visaram reconfigurar o formato do curso. A nova configuração envolvia mudanças acentuadas de estrutura de ensino como também na forma e nos meios de ensinar. A educação por si só se trata de um processo em contínua mudança, conforme Aranha (2006, p. 18), "trata-se de um processo que dura a vida toda e não se restringe à mera continuidade da tradição, pois supõe a possibilidade de rupturas, pelas quais a cultura se renova e o homem faz e refaz a história”. Necessidade de ressignificar nossas concepções e práticas era o que o contexto exigia, e assim o fizemos.

Sabemos que o processo educativo traz desafios e, muitas vezes, requer ajustes que não são fáceis de adaptar, são condições de rupturas e continuidades do processo educativo dentro do contexto social. Aranha (2006, p. 19) também afirma que "não nos compreendemos fora da nossa prática social, porque esta, por sua vez, se encontra mergulhada em um contexto histórico-social concreto". Assim, o contexto social que se apresentava exigia mais que pensar e repensar sobre a situação apresentada, requeria ações imediatas. Era preciso aprender para adaptar, planejar, elaborar e agir.

De tal modo, incentivadas pelos alunos, iniciamos a oferta do curso de português $100 \%$ a distância, em um formato diferente do qual estávamos acostumadas. Fizemos, então, reuniões para decidirmos como nos organizar para esta nova modalidade de ensino. Uma das professoras pertencentes ao projeto 
foi quem nos orientou desde o início, pois possuía experiência com o ensino remoto e enquanto nos orientava nas ações, aos poucos, as outras professoras foram se atualizando para se adaptar ao novo contexto. Em seguida, fizemos a divulgação do curso no site do departamento de Línguas Estrangeiras da Universidade e nas redes sociais. Também decidimos abrir novas inscrições, pois percebemos que com essa modalidade de ensino, poderíamos ter alunos de outros cidades, estados e até mesmo de outros países.

O site “Todos pela educação" apresentou no mês de abril de 2020 uma "Nota técnica Ensino a Distância na Educação Básica Frente à Pandemia da COVID-19" (2020, p. 5) e menciona:

Pesquisas apontam que, quando o assunto é ensino a distância, o trabalho dos professores tem papel significativo no sentido de assegurar uma boa experiência, independentemente da solução utilizada. Diante do cenário atual, em que são igualmente impactados pela pandemia, apoiá-los, pessoal e profissionalmente, é medida absolutamente fundamental.

Nesse sentido, obtivemos total apoio do Departamento de Línguas estrangeiras da Universidade Federal de Rondônia, no esforço mútuo da equipe de docentes, discentes e membros integrantes externos que fazem parte do programa e do projeto. $\mathrm{O}$ curso passou a ter grande aceitação, com alunos imigrantes que moram em diferentes lugares do Brasil, assim como alunos de outros países. É interessante observar que esta nova modalidade de ensino nos mostrou que também os alunos não estavam preparados. Assim, tornou-se imprescindível que tivéssemos uma pessoa no projeto que fosse responsável por auxiliar os alunos a manusear a plataforma utilizada (Google Classroom), como por exemplo, fazer os exercícios, enviar para as professoras e esclarecer diversas dúvidas técnicas que foram surgindo no transcorrer do curso.

Como observamos anteriormente, alguns alunos não dominavam as novas ferramentas de aprendizagem, assim houve a necessidade de atender a cada um que apresentasse a dificuldade, ensinando o passo a passo, pois adquirir a nova habilidade era indispensável para que o aluno realizasse as atividades, 
acompanhasse os conteúdos e as aulas, ou seja, aprender como utilizar a nova plataforma de ensino precisaria ocorrer com uma certa celeridade.

Sobre obstáculos como esses, a nota técnica do site "Todos pela Educação" (2020, p. 7) destaca o seguinte:

[...] a mudança rápida e complexa que o cenário atual exige torna a tarefa ainda mais desafiadora. Dificuldades de adaptação ao modelo de ensino remoto são naturais e deverão ocorrer de forma ainda mais acentuada no Brasil, uma vez que o uso consistente de tecnologias ainda tem presença muito tímida nas redes de ensino. Exemplos de obstáculos existentes são o desconhecimento sobre a qualidade da maior parte das soluções disponíveis, a pouca familiaridade dos alunos e profissionais com as ferramentas de ensino a distância e a falta de um ambiente familiar que apoie e promova o aprendizado online

O modelo remoto de ensino trouxe necessidade de muitas adaptações, percebemos, todavia, que alguns alunos desistiram do curso, contudo essa nova modalidade ampliou o público e alcançou alunos de outros estados do país, como também fora do país. Ao longo do curso, observamos que outro problema enfrentado pelos imigrantes foi que muitos deles não conseguiram participar do curso de Português na modalidade online, visto que não possuíam internet wifi em casa, apenas dados móveis quando conseguiam recarregar seus celulares, o que não ocorria com frequência pela falta de condições financeiras. Observamos também que a maioria possuía apenas celular e não laptop para realizar as atividades na plataforma "Google Classroom" e para assistir às aulas online que eram oferecidas pelo Google Meet.

A nota técnica do "Todos pela Educação" (2020, p. 6) enfatiza "Estratégias de ensino a distância deverão cumprir papel importante para a redução dos efeitos negativos do distanciamento temporário". Assim, logo nas primeiras aulas, com o objetivo de conscientizar os alunos sobre o novo vírus e forma de prevenção, discutimos sobre os impactos da pandemia nas suas vidas, levando-os a reflexões de possíveis alternativas para os impactos apontados e, em seguida, solicitamos como conteúdo das atividades a elaboração de um texto 
sobre "Impactos da pandemia na sua rotina como migrante". Essa atividade foi realizada no Google Classroom, plataforma a qual utilizamos para as aulas.

Nas aulas seguintes, realizamos atividades referentes à conversação com o tema sobre fake news e suas consequências. Os alunos participaram demonstrando muito interesse e envolvimento ao manifestarem sua opinião. Assim, foi possível desenvolver momentos de interculturalidade ao trocar experiências sobre como este tema estava sendo tratado em cada país de origem dos alunos. Portanto, nesta aula, a sequência didática incluiu aula online com discussões sobre o referido tema, apresentação de exemplos de fake nerws coletados da web, desenvolvimento de estratégias de leitura, iniciando com a exploração do pré-conhecimento do tema, partindo para a indicação dos cognatos e falsos cognatos do texto. Em seguida, passamos para a identificação as palavras familiares e, depois disso, para a captação da ideia central de cada parágrafo, culminando em perguntas escritas sobre o texto em geral. Também alertamos sobre a necessidade de checar as notícias antes de a compartilharem para não serem punidos pela legislação vigente.

Para dar continuidade ao tema apresentamos alguns textos do site do Ministério da Saúde ${ }^{3}$ sobre Fake News envolvendo a COVID-19. Eles deveriam escolher até quatro textos para fazer a tradução do português para a sua língua materna (espanhol, francês, inglês, etc.). Essa atividade teve como objetivo trabalhar, a partir dos textos, os temas transversais, a ampliação do vocabulário, a ampliação do conhecimento gramatical e a divulgação social para minimizar o impacto da COVID-19. Após a correção, eles enviariam os textos para seus contatos e familiares. Consideramos que os envios destas traduções foram de suma importância para o engajamento e a construção coletiva no combate e aos efeitos da pandemia para criar espaços de problematização, produção de cuidado e práticas de produção de vida para evitar a disseminação do vírus.

Os textos trabalhados envolveram os temas transversais sobre saúde, ética e cidadania, os quais oportunizaram a aproximação da realidade do aluno, trouxeram o debate desta questão social vivenciada no momento atual e propi-

3 Mais informações em: <https://www.saude.gov.br/component/tags/tag/novo-coronavirus-fake-news> Acesso em: 17 jun. 2020 
ciaram reflexões sobre as implicações que envolvem esse assunto e colaboraram para uma aprendizagem significativa em contexto autêntico.

Com o objetivo de minimizar o impacto da pandemia entre o grupo mais vulnerável da comunidade, também participamos de diversas ações de enfrentamento à pandemia da COVID-19, promovidas pelos servidores e estudantes da Fundação Universidade Federal de Rondônia (UNIR). Algumas destas ações foram: arrecadação de equipamentos de proteção, distribuição de cestas básicas, checagem de fake news, realização de novas pesquisas sobre o vírus, desenvolvimento de medicamentos, de respiradores e de protótipo de cabine de desinfecção ${ }^{4}$.

Em relação às estratégias adotadas pelas instituições de ensino no contexto epidêmico, a Nota Técnica do Todos pela Educação (2020, p. 15) enfatiza: "diante do contexto, por mais consistente que seja a estratégia adotada, ela poderá, na melhor das hipóteses, minimizar impactos negativos". Com esse intuito, além das atividades descritas acima, nosso programa, juntamente com o restante dos docentes do Departamento de Línguas Estrangeiras, realizou a doação de cestas básicas, produtos de higiene pessoal e limpeza, confecção de máscaras para pessoas em situação vulnerável, sendo contemplados alguns alunos do curso de Letras Estrangeiras, moradores de rua, pessoas do grupo de risco e os imigrantes do curso de português.

Com essas ações acreditamos que, de alguma forma, foi possível contribuir para minimizar a disseminação do coronavírus, bem como diminuir os efeitos negativos da pandemia em relação àqueles que não têm acesso a condições básicas de prevenção e proteção.

\section{CONSIDERAÇÕES FINAIS}

A pandemia do novo coronavírus, sem dúvida, trouxe para cada um de nós mudanças em alguns ou vários aspectos da vida. Como dissemos, indivíduos, família e instituições, todos tivemos que nos adaptar bruscamente a um contexto de situações novas que demandaram mudanças sociais, estruturais,

4 Essas informações podem ser acessadas em: <https://www.unir.br/index.php?pag=noticias\&id=28248>Acesso em: 15 jun. 2020. 
mentais e emocionais. Contudo, os que mais sofrem diante da necessidade de readaptação são aqueles que não têm condições financeiras de obtê-la.

Em maior proporção, o sistema socioeconômico hegemônico traz consequências ainda piores no contexto de uma epidemia, pois os mais atingidos são os que não podem obter e manter uma boa estrutura de prevenção e proteção.

A disseminação de fakes news sobre a COVID-19 somente agravou a situação e trouxe consequências desastrosas, imensuráveis à sociedade. Nesse sentido, as atividades desenvolvidas em nossas aulas, tais como as reflexões sobre as fake newws e suas consequências, a tradução dos textos do Ministério da Saúde e o compartilhamento dos mesmos nas redes sociais, além das doações de cestas básicas, produtos de higiene pessoal e limpeza e máscaras, contribuíram para amenizar os efeitos do vírus.

Assim sendo, nós, enquanto educadores e professores em formação, no que tange ao nosso papel social, neste contexto epidêmico, precisamos desenvolver estratégias, que na melhor das intenções, possam minimizar efeitos negativos. Faz-se necessário também possibilitar, aos nossos discentes, oportunidades de produção e reflexão sobre o contexto atual de suas vivências. Desta maneira, estamos ajudando a torná-los indivíduos críticos de sua realidade e com uma visão macro sobre os problemas mundiais. Assim, acreditamos que o trabalho com os temas transversais cumpre de forma satisfatória esse papel.

É, então, evidente a importância de trazer temas transversais para a aula de línguas, porque além de ensinar outra língua, esses temas auxiliam os discentes na formação de seu caráter de cidadão e na consciência crítica para o mundo social. Dessa forma, o processo educativo, atendendo às demandas sociais, engloba as necessidades dos alunos e da comunidade.

Por fim, destacamos que o processo de ensino aprendizagem por si só impulsiona os professores a buscar por inovações no fazer pedagógico. Portanto, o contexto pandêmico, que estamos vivenciando, de maneira mais intensa, demanda inovações. Conforme já dito, nos tirou da rotina da sala de aula para uma busca por adaptações e ressignificações no processo de ensino-aprendi- 
zagem, nos levando a mudanças em diversos aspectos tanto na questão educacional como na questão de rever nosso papel como educadores e cidadãos responsáveis por contribuir na prevenção e, consequentemente, diminuição dos impactos causados pela COVID-19.

\section{REFERÊNCIAS}

ARANHA, Maria L. de Arruda. História da educação e da pedagogia: geral e Brasil. 3. Ed., São Paulo: Moderna, 2006.

ARAÚJO, U. F. Temas transversais e a estratégia de projetos. São Paulo: Moderna, 2003.

BRASIL. Ministério da Educação. Base Nacional Comum Curricular. Secretaria de Educação Fundamental-Brasília, MEC/SEF, 2017. Disponível em: http://basenacionalcomum.mec.gov.br/abase/. Acesso em: 10 de jun. 2020.

BRASIL. Secretaria de Educação Fundamental. Parâmetros Curriculares Nacionais: terceiro e quarto ciclos: apresentação dos temas transversais. Secretaria de Educação Fundamental - Brasília, MEC/SEF, 1998. Disponível em: http:// portal.mec.gov.br/seb/arquivos/pdf/livro01.pdf Acesso em: 5 de jun. 2020.

Parâmetros Curriculares Nacionais: Apresentação dos temas transversais. Brasília: MEC, 1997.

DAVIS, M. A crise do coronavírus é um monstro alimentado pelo capitalismo. In: DAVIS, Mike, et al: Coronavírus e a luta de classes. Terra sem Amos: Brasil, 2020.

DAVIS, M. et al Coronavirus e a luta de classes. Terra sem Amos: Brasil, 2020, p.5-12.

HARVEY. D. Política anticapitalista em tempos de COVID-19. In: DAVIS, Mike, et al Coronavírus e a luta de classes. Terra sem Amos: Brasil, 2020, p.13-23. 
MORENO, M. Temas transversais: um ensino voltado para o futuro. In: BUSQUETS, M. et ali. Temas transversais em educação. SP: Ática, 1998.

NOTA TÉCNICA Ensino a Distância na Educação Básica Frente à Pandemia da COVID-19.Todos pela Educação, 2020. Disponível em: https://www.todospelaeducacao.org.br/_uploads/_posts/425.pdf?1730332266=\&utm_source=conteudo-nota\&utm_medium=hiperlink-download. Acesso em: 20 de jun. 2020.

SALES, L. O. Consequências penais da divulgação de fake news sobre a pandemia. Disponível em: https://www.migalhas.com.br/depeso/326753/ consequencias-penais-da-divulgacao-de-fake-news-sobre-a-pandemia. Acesso em: 20 de jun. 2020.

SANCHES PÉREZ, A. Los métodos en La enseñanza de idiomas. Evolución histórica y análisis didáctico. Madrid, SGEL, 1997. 


\section{CAPÍTULO 12.LAENSEÑANZA DE ESPAÑOL CON FINES ESPECÍFICOS PARA LUSOHABLANTES: DESAFÍOS DO- CENTES Y NUEVAS PERSPECTIVAS}

Juan Hernández-Ortega

Reny Gomes Maldonado

\section{Introducción}

La enseñanza de lenguas con fines específicos constituye una fecunda rama de los estudios de enseñanza de segundas lenguas muy desarrollada en las últimas décadas. Habiendo surgido históricamente para la enseñanza del inglés, hoy día los estudios de Español con Fines Específicos (EFE) constituyen una fecunda rama de los estudios de Español como Lengua ExTRANJERA (ELE). Estos estudios de enseñanza de lenguas con fines específicos pertenecen, pues, a la lingüística aplicada.

Los estudios de enseñanza de lenguas con fines específicos tienen por objeto, a partir de la caracterización lingüística y sociocultural de ciertos lenguajes de especialidad, establecer metodologías teóricas y prácticas para la enseñanza, el conocimiento y el aprendizaje de lenguajes sectoriales de carácter profesional, científico o académico. En este sentido, además de la perspectiva teórica («el conocimiento»), estos estudios incorporan una doble vertiente práctica, enfocada hacia el profesor o formador («la enseñanza») y hacia el estudiante o alumno («el aprendizaje»). Por el momento, de estos dos últimos, el aspecto más desarrollado es el segundo, esto es, el orientado al proceso de aprendizaje (el alumno), más que el orientado al proceso de enseñanza (el profesor) ${ }^{1}$.

Una de las principales ocupaciones de índole práctica de estos estudios estriba en el establecimiento de metodologías aplicadas para el diseño de cur-

1 A pesar de que no podremos dedicarnos a ello, es importante señalar en este punto que otro aspecto insuficientemente desarrollado en los estudios de EFE es el de la formación de formadores en EFE. 
sos especializados en la enseñanza y el aprendizaje de estas lenguas de especialidad a hablantes extranjeros. En este sentido, y a título ilustrativo, un curso de inglés de la aviación impartido a aspirantes a tripulación de vuelo, un manual de español jurídico publicado por una prestigiosa editorial de materiales de español para extranjeros, una asignatura de francés para ciencias de la salud encuadrada en el plan de estudios de una licenciatura en Lenguas Modernas en una universidad portuguesa o un examen de un certificado de mandarín de los negocios ofrecido por una cámara de comercio exterior serían productos típicos de los estudios de enseñanza de lenguas con fines específicos.

De este modo, en numerosos contextos podemos observar un auge de estos productos lingüísticos de carácter «sectorial». Así, a los cursos generales de enseñanza de lenguas extranjeras, del tipo de «Pre-intermedio de inglés», «Especialización en lengua y cultura portuguesas de nivel superior» $\mathrm{O}$ «Curso intensivo de español de nivel B2», se les suman los específicos del tipo «Certificación avanzada en portugués de los negocios», «Curso de español para ciencias de la salud» o «Escuela de verano de inglés académico». La importancia de este tipo de formación sectorial o especializada cobra especial relevancia cuando desde el punto de vista institucional se promueven políticas que exigen estar en posesión de determinadas certificaciones lingüísticas oficiales o cuando, p. ej., es necesario acreditar el conocimiento particular de una lengua.

Sin embargo, frente a una proliferación, tanto desde el punto de vista teórico (estudios) como del aplicado (materiales, cursos, certificaciones...), de este tipo de estudios, puede observarse una ausencia significativa de la perspectiva contrastiva, pues no resulta habitual encontrar esta vertiente comparada. La bibliografía sobre español con fines específicos es abundante; para obtener una orientación mayor, remitimos a la Orientación bibliográfica incluida al final del presente trabajo.

El presente trabajo pretende ser una guía sintética para el profesor de EFE para lusohablantes, centrándose como guía básica para el profesor recién licenciado, formado o graduado. Asimismo, pretendemos ofrecer la perspectiva contrastiva cuya carencia se ha señalado. 
La estructura del trabajo es la siguiente ${ }^{2}$. En el apartado segundo, realizaremos una breve introducción teórica del área de EFE para profesores recién formados o para profesionales que no se hayan acercado todavía a los conceptos básicos. En los apartados tercero y cuarto abordaremos, respectivamente, los desafíos y las perspectivas que consideramos de importancia, interés y utilidad que deben ser tenidos en cuenta a la hora de preparar materiales específicos de EFE para lusohablantes, prestando especial atención a la adaptación de los contenidos del currículo. Tras las perspectivas de trabajo e investigación, ofrecemos además una orientación bibliográfica comentada, que podrá ayudar al profesor debutante en la materia. Cierran el trabajo las referencias bibliográficas.

\section{La enseñanza del español con fines específicos}

La enseñanza de lenguas con fines específicos surge a finales de los años sesenta del siglo XX con la aparición del enfoque comunicativo ${ }^{3}$. En un principio, se observó para el inglés la existencia de necesidades de comunicación particulares o de grupos específicos de aprendices; de ahí surgió la denominación original: English for Specific Purposes. Inicialmente, se estableció una clasificación cuatripartita, básicamente mantenida hasta hoy:

\section{ESP (English for Specific Purposes)}

2. EAP (English for Academic Purposes)

3. EST (English for Science E Technology)

4. EOP (English for Ocupational Purposes)

La denominación 'Español con Fines Específicos' (en adelante, podrá usarse la sigla EFE), que se extiende a comienzos de la década de los noventa, hoy se encuentra consolidada y constituye una relevante rama de los estudios de ELE.

2 Este trabajo constituye una versión modificada y ampliada de la conferencia que los autores profirieron en la modalidad 'en línea' el día 30 de junio de 2020 en el seno del ciclo Charlas sin fronteras, para la Universidad Federal de Rondonia (UNIR). La versión previa contenía una parte de orientación y perspectivas de trabajo para el profesor graduado en Letras - Español que no se incluye en el presente texto.

3 Pueden ampliarse estas consideraciones en los trabajos de Aguirre Beltrán (2004), Gómez de Enterría (2007) y Martín Peris (dir.) (2008), entre otros. Sobre la historia de los métodos de enseñanza de lenguas y el punto de inflexión que marca la irrupción del método comunicativo, puede verse el trabajo de Sánchez Pérez (1992) y las referencias allí contenidas. 
Siguiendo a Martín Peris (dir.) (2008), podemos ofrecer la siguiente caracterización. La enseñanza de la lengua para fines específicos tiene por objeto los procesos de enseñanza-aprendizaje que facilitan el dominio de la comunicación especializada en una lengua particular. Con 'comunicación especializada' nos referimos a la lengua que utilizan los profesionales que trabajan en un determinado contexto comunicativo (laboral, académico...). La denominación 'español con fines específicos' alude al conjunto de usos del español empleado en cada uno de estos ámbitos del campo profesional o académico.

De manera general, y en función de la evolución de los estudios sobre español con fines específicos, se ha establecido una división de estas enseñanzas en dos grandes grupos:
A. Español con fines profesionales (EFP)
B. Español con fines académicos (EFA)

Independientemente de esta clasificación bipartita, y sin entrar a discutirla desde el punto de vista teórico, podemos encontrar cursos, materiales y manuales de español con fines específicos atendiendo a diversas subáreas de especialización. Algunas de estas áreas tradicionalmente reconocidas son las que podemos observar en el Cuadro I.

- El español para el entorno laboral, la empresa y los negocios

- El español para las ciencias de la salud

- El español jurídico y para el entorno legal

- El español del turismo

- El español de la diplomacia y las relaciones internacionales

- El español para fines académicos y docentes ${ }^{4}$

- El español para la ciencia y la tecnología

- Español para la traducción ${ }^{5}$

Cuadro I.- Áreas tradicionalmente reconocidas en los estudios de español con fines específicos.

4 Exámenes de competencia [Exame de Proficiência] (grado, posgrado).

5 Vid. la orientación bibliográfica ofrecida al final del presente estudio. 
Igualmente, estos lenguajes sectoriales han sido también denominados 'lenguas de especialidad' o 'lenguajes especializados'. En ese marbete, han sido incluidos también algunas áreas que generalmente no se consideran en los estudios de ELE. En este sentido, los estudios de EFE tomarían algunos de los lenguajes de especialidad para enfocar en su didáctica a extranjeros. Siguiendo a Emilio Alarcos, estos lenguajes especializados serían «[s]ubsistemas de la lengua común o estándar, referidos principalmente al léxico (y muy en menor grado a la morfología y a la sintaxis), por medio de los cuales se identifica un determinado ámbito sociocultural» (Alarcos Llorach, 1981: 139, apud Calvi, 2006: 9). Desde una perspectiva más amplia que la de ELE, y basándonos en estos autores, podríamos ofrecer una clasificación general de las lenguas de especialidad, mediante el siguiente cuadro, en el que se presenta la intersección de dos parámetros: si estos lenguajes de especialidad poseen finalidad críptica o no, y si presentan comprensión del no iniciado o no.

\begin{tabular}{|c|c|c|}
\hline \multicolumn{3}{|c|}{ Lenguajes especializados } \\
\hline Con finalidad críptica & & in finalidad críptica \\
\hline \multirow{2}{*}{$\begin{array}{l}\text { Lenguajes de grupos socia- } \\
\text { les: 'ARGOTs' o 'JERGAS': } \\
\text { - lenguaje de los marineros } \\
\text { - lenguaje de los jóvenes } \\
\text { - lenguaje de los delincuentes } \\
\text { - lenguaje de los espías } \\
\text { - etc. }\end{array}$} & $\begin{array}{l}\text { Comprensión } \\
\text { del no iniciado }\end{array}$ & $\begin{array}{l}\text { Lenguajes de actividades y } \\
\text { pro-fesiones: 'LENGUAJES SECTO- } \\
\text { RIALEs': } \\
\text { - Lenguaje de la política } \\
\text { - Lenguaje del deporte } \\
\text { - Lenguaje administrativo } \\
\text { - Lenguaje jurídico } \\
\text { - Lenguaje periodístico } \\
\text { - etc. }\end{array}$ \\
\hline & $\begin{array}{l}\text { Incomprensión } \\
\text { del no iniciado }\end{array}$ & $\begin{array}{l}\text { Lenguajes de diversas ciencias: } \\
\text { 'LENGUAJES CIENTífico-TÉc- } \\
\text { NICOs': } \\
\text { - Lenguaje de la medicina } \\
\text { - Lenguaje de la química } \\
\text { - Lenguaje de la lingüística } \\
\text { - etc. }\end{array}$ \\
\hline
\end{tabular}

CuAdro II.- Hacia una posible clasificación de las lenguas de especialidad. 


\section{Los desafios del profesor de español con fines específicos para lusohablantes}

Según se ha hecho notar, la presencia de la perspectiva contrastiva español-portugués en relación con la enseñanza de lenguas con fines específicos no ha recibido la suficiente atención. Este hecho salta a la vista al constatar la ausencia de suficiente bibliografía especializada. En este apartado pretendemos ofrecer un panorama sobre los desafíos del profesor de cursos de español con fines específicos para lusohablantes. Para ello, es necesario prestar atención a tres clases de desafíos que se presentan al docente a la hora de aplicar esta perspectiva contrastiva:

A. Los propios de un curso de español con fines específicos

B. Los propios de un curso de español para lusohablantes

C. Los derivados de la conjunción de un curso de EFE para lusohablantes

Así pues, comentaremos los desafíos del profesor de EFE para lusohablantes a partir de los diferentes aspectos que se enumeran en el Cuadro III, ofrecido a continuación. Según iremos especificando, en ocasiones, los aspectos comentados son de aquellos que deben ser considerados por cualquier docente que prepare un curso de EFE; en otras ocasiones, se tratará de aspectos derivados de la aplicación de un curso de EFE a lusohablantes.

\begin{tabular}{|l|l|}
\hline - El fin particular meta del aprendizaje & $\begin{array}{l}\text { Español jurídico, para ciencias de la } \\
\text { salud, para los negocios... }\end{array}$ \\
\hline - Los participantes & $\begin{array}{l}\text { el alumno y el alumnado (la clase) } \\
\text { el profesor } \\
\text { la institución }\end{array}$ \\
\hline - El contexto físico de aprendizaje & el país de aprendizaje \\
\hline - Los aspectos didácticos & $\begin{array}{l}\text { a) la programación y los contenidos } \\
\text { b) las cuestiones metodológicas } \\
\text { c) Los materiales de apoyo } \\
\text { d) La evaluación } \\
\text { e) El canal o el medio }\end{array}$ \\
\hline - El currículum & $\begin{array}{l}\text { Las destrezas } \\
\text { Los contenidos lingǘsticos } \\
\text { Los contenidos extralingüísticos }\end{array}$ \\
\hline - Los niveles & La adaptación de los niveles \\
\hline
\end{tabular}

CuAdro III.-Factores que han de ser considerados a la hora de diseñar un curso de EFE, sea general o para lusohablantes. 


\subsection{Aspectos relativos al curso de español}

a) El fin específico particular que se enseña (negocios, turismo, académico...).

b) La naturaleza del alumnado (edad, homogeneidad, necesidades individuales y del grupo, etc.).

c) Su nivel de lengua previo (curso para iniciantes, de especialización...).

d) La institución que alberga el curso (centro universitario, escuela primaria, centro privado...), si esta existe (frente, p. ej., a una clase particular).

e) El canal físico de impartición (clase presencial frente a clase en línea o remota; espacio «formal», como un aula, frente a «informal», como una cafetería, etc.).

f) Las condiciones materiales y los recursos disponibles (que el aula disponga de pupitres anclados al suelo o movibles o de pizarra, etc.).

g) La posible utilización de materiales adaptados (uso de manual general de ELE, uso de un manual específico de EFE, uso de materiales y recursos complementarios, creación de materiales propios...).

h) El propio perfil del profesor (grado de experiencia, formación específica en ELE frente a "paracaidistas» de la profesión, lengua materna, nivel de conocimiento de la lengua meta, etc.).

\subsection{Cuestiones relativas al alumno en particular y al alumnado en tanto que grupo.}

i) La motivación del alumnado.

j) El grado de conocimiento de las nuevas tecnologías y recursos, y su destreza en el uso de estas.

k) El tiempo de que dispone el alumno para su formación.

1) Necesidad de superación de determinados exámenes (DELE, exámenes particulares de acceso a determinados cursos, etc.).

\subsection{En relación con los desafíos propios de un curso de español para lusoha- blantes, podrán y deberán ser tenidos en cuenta aspectos como los siguientes:}

a) El grado de conocimiento previo de la lengua española por parte del alumno lusohablante. 
b) Si el curso implica consolidación y refuerzo del nivel de lengua previo conocido o si implica ampliación del nivel.

c) El nivel de español que se pretende adquirir o consolidar tras la finalización y conclusión satisfactoria del ciclo formativo, en caso de que se pretenda ampliación del nivel preexistente.

d) El lugar y el contexto de toma del curso por parte del alumno lusohablante (en un contexto de inmersión en un país hispanohablante, en un país lusohablante, en un lugar ni hispanohablante ni lusohablante, con alumnos de lenguas maternas terceras.

e) La utilización de materiales adaptados a lusohablantes.

f) En caso de utilización de materiales generales, si se hace adaptación para los fenómenos propios de «lenguas próximas»: desde la no necesidad de explicación de ciertos fenómenos gramaticales (EJEMPLOS) hasta la necesidad de énfasis en ciertos vocabularios contrastivos (falsos amigos en ciencias de la salud, en español de los negocios, el turismo, el léxico de los delitos en el español jurídico, del comercio, etc.).

g) Atención a la variedad lingüística del español que se enseña (variación geográfica o dialectal).

h) La adaptación de materiales propia a lusohablantes (para las adaptaciones propias de un curso de EFE para lusohablantes, vid. infra apdo. XXX).

3.4. Una vez examinados de manera separada los desafíos propios de un curso EFE y de un curso de español a lusohablantes, pueden y deben ser examinados los siguientes aspectos derivados de la conjunción de un curso de español con fines específicos para lusohablantes.

- La idea fundamental estriba en la adaptación del léxico, esto es, en la creación de unidades temáticas de vocabulario, particularmente adaptadas; deberán, también, prestar particular atención a los falsos amigos.

- El segundo de los aspectos es el de la adaptación del currículo. De este aspecto, hablaremos particularmente en el apartado $4 .^{\circ}$ del presente trabajo.

- Quedan fuera de este trabajo reflexiones interesantes como la de la adaptación de los niveles del Marco Común Europeo de Referencia para las Lenguas; esto es, la cuestión de las lenguas próximas. 
Igualmente, podrán ser considerados otros aspectos:

- Conocimientos socioculturales particulares (p. ej., conocimiento de la geografía de país(es) hispanohablantes para profesionales del turismo que pretendan vender viajes a estos países; conocimiento de la geografía del país de trabajo para el turista hispanohablante).

- El acceso a ciertos exámenes o pruebas (el denominado ‘cursinho' o los exámenes de acceso a la Medicina en España).

- El análisis de los sistemas educativos.

- El análisis de ciertas necesidades individuales.

- El análisis de ciertas necesidades de mercado.

- Español académico. Programas de intercambio. Estudiantes de movilidad.

- La traducción y la traducción jurada.

\section{Reflexiones perspectivas y prospectivas}

A continuación, consideraremos brevemente qué aspectos deben ser considerados particularmente a la hora de adaptar un curso de EFE para lusohablantes.

Es obvio que no existen estructuras gramaticales «particulares» $\mathrm{o}$ «exclusivas» de los lenguajes de especialidad, a pesar de que puedan reconocerse en algunas de ellas ciertos rasgos sintácticos arcaizantes o pertenecientes al registro culto; v. g., ciertos rasgos que habitualmente se reconocen como propios del lenguaje jurídico o administrativo, como la presencia de futuros de subjuntivo (Quien cometiere tal delito, será condenado a...), tiempo desconocido por la lengua coloquial; el uso habitual de construcciones absolutas del tipo Habiendo sido probados los hechos referidos, construcciones no habituales en la lengua coloquial y que, por consecuencia, no se enseñan en los cursos habituales de ELE (aunque son similares en la lengua portuguesa); o el uso de relativos cultos (como cuyo o el cual), que cada vez más se alejan del uso conversacional, entre otros.

Dado que las estructuras ortográficas, fónicas y las gramaticales son esencialmente las mismas, deberá prestarse especial atención a aspectos lexicológicos y pragmáticos. Así, a la hora de preparar un curso de español con fines específicos, en función del área particular de necesidad, será necesario prestar especial atención a aspectos como los que se engloban en el Cuadro IV. 
I. Aspectos lexicológicos

1. Léxico especializado, perteneciente a campos semánticos particulares.

2. Expresiones fraseológicas y formulaicas particulares.

II. Aspectos pragmáticos y socioculturales

3. Formas de tratamiento y expresiones de cortesía.

4. Fórmulas estereotipadas y expresiones adaptadas para situaciones codificadas particulares.

Cuadro IV.- Aspectos lingüísticos y socioculturales que han de ser tenidos en cuenta a la hora de adaptar un curso de EFE enfocado para lusohablantes.

Lo que hacen los manuales de español con fines específicos es realizar unidades didácticas sistémicas (Regueiro Rodríguez, 2014, 2016) de temática centrada en el área de interés; así, p. ej., la unidad 10 del método Emprendedores 2 (nivel B1 del Marco Común Europeo de Referencia), de la editorial SGEL, que tiene por objetivo "asesorar a una empresa en crisis», se auxilia para conseguirlo de diversos tipos de textos (correos electrónicos, entrevistas, gráficos, revistas digitales...) y mediante la inclusión de información de contenido sociocultural, como piezas sobre la financiación de las empresas o apuntes histórico-culturales en los que se habla de anteriores crisis económicas.

Por su parte, podemos encontrar un sinnúmero de aspectos para ejemplificar:

- Tecnicismos, latinismos, comunes al lenguaje jurídico de tradición hispana y de tradición luso-brasileira.

- Lenguaje jurídico

- Expresiones fijadas, del tipo No ha lugar.

- Estilo (periodos sintácticos muy largos).

- Cursos inglés para aeropuertos (ejemplo); español para aeropuertos locales.

- Léxico y sintaxis de las ciencias de la salud: Determinados usos verbales diferentes a la lengua coloquial (El paciente refiere un fuerte dolor de cabeza).

Igualmente, surgen otro tipo de reflexiones.

- Reflexiones sobre la naturaleza de los cursos. 
- Un curso de EFE no es algo inconexo con un currículo general de enseñanza de español.

- Qué debe ser y qué no debe ser un curso de EFE para lusohablantes.

- No debe ser un mero repertorio de vocabulario especializado.

- Debe basarse en unidades didácticas sistémicas (Regueiro Rodríguez, 2014, 2016) (citar modelos de manuales en el mercado); preguntar a Marisa si tiene algún favorito; ofrecer listas de manuales, o un somero panorama.

- Reflexiones con atención al abordaje contrastivo

- Creación y adaptación de materiales

- Reflexiones con atención a la realidad estructural

- Atención a los sistemas educativos

- Cambios para la inclusión de programas especializados en universidades e institutos universitarios de lenguas

- Propuestas para la realización de cursos de carácter pan- o trans-románico (p. ej., enseñanza de lenguaje de especialidad de los negocios en PT, ESP, FR, IT, o incluso de lenguas más alejadas, ING, chino; valor de la perspectiva contrastiva).

- La existencia de exámenes o certificaciones particulares de la enseñanza de EFE, examen cámara comercio.

- La cuestión de la enseñanza de la lengua a inmigrantes (Santiago Guervós - Fernández González, 2017: § 25.3.2): ¿la enseñanza de la comunicación básica no es un fin específico en sí mismo? EFE para los inmigrantes que llegan. Fines específicos para comunicación básica para el que atiende a los refugiados. (Algunos casos especiales: enseñanza a inmigrantes, refugiados, víctimas de conflictos. Labores de intérprete).

- Reflexiones con atención a la realidad coyuntural

- Las modificaciones en la legislación educativa (inclusión o no del español como segunda lengua obligatoria)

- La cuestión de la pandemia y las clases remotas u online

- Reflexiones sobre la innovación docente

- Nota sobre los medios de difusión (canal online)

- Nota sobre el auxilio a través de nuevas tecnologías y redes sociales 
- Perspectivas de investigación

- En lingüística aplicada.

- Verificación del enfoque contrastivo en EFE.

- Creación de vocabularios temáticos contrastivos.

- Aspectos teóricos y aplicados (traducción, lexicografía, glosarios terminológicos...).

- Análisis, creación y adaptación de materiales, métodos y cursos. (Editoriales...).

- La Reversibilidad del enfoque contrastivo: enseñanza de portugués como lengua extranjera para fines específicos para hispanohablantes.

- El Autoaprendizaje.

- La ampliación del enfoque contrastivo.

Enfoques menos vistos

Corresponsales de prensa. El lenguaje del deporte. Los periodistas internacionales, corresponsales de guerra, diplomacia. Lengua de la publicidad.

Lenguaje de la aviación.

\section{Orientación bibliográfica}

Tanto el profesor iniciante de español con fines específicos como los alumnos recién graduados o de los últimos cursos de licenciatura podrán encontrar orientación básica en los siguientes textos introductorios — escritos en español一, además de en las fichas que estos contienen: Aguirre Beltrán (2004,2012), Gómez de Enterría (coord.) (2001) y Gómez de Enterría (2007, 2009), el cap. 25. o de Santiago Guervós - Fernández González (2017) y el número 44 de la revista Carabela (1998), monográfico dedicado a la materia, con interesante bibliografía temática adicional — aunque algo antigua ya — y disponible en línea. A la hora de adaptar un curso de ELE para fines específicos, para el diseño de unidades didácticas, programarlo, estrategias, técnicas docentes, resultan imprescindibles los dos libritos, interconectados entre sí, de Regueiro Rodríguez (2014, 2016).

En cuanto al estudio teórico individual de algunas de las lenguas de especialidad particulares, podrá encontrarse importante ampliación, entre otros 
trabajos, en las siguientes monografías: Calvi (2006), para el español del turismo; Regueiro Rodríguez - Sáez Rivera (2013), para el español académico; Gutiérrez Rodilla (2005) y Vivanco Cervero (2006), para el español de la ciencia y la tecnología; Suau Jiménez (2010), para la traducción especializada; Hernández Alonso (2003), para el lenguaje del deporte. Asimismo, desde el punto de vista aplicado, las principales editoriales de materiales de ELE (Anaya, Difusión, Edelsa, Edinumen, Enclave-ELE, SGEL, SM...) poseen en sus catálogos, accesibles en línea todos ellos, diversos métodos y manuales sobre las diferentes ramas del español con fines específicos (español de los negocios, español del turismo, español para ciencias de la salud, español jurídico...).

En lengua inglesa existe abundantísima bibliografía de carácter teórico sobre la enseñanza de lenguas con fines específicos; los siguientes trabajos podrán resultar, sin duda, de interés para continuar profundizando en la materia. Con respecto al inglés con fines específicos, constituyen referencias fundamentales de carácter introductorio el texto clásico de Hutchinson - Waters (1987) y el reciente de Anthony (2018), y de ellos pueden extraerse valiosas observaciones extrapolables para la enseñanza de las lenguas (ibero-)románicas bajo la perspectiva que nos ocupa.

Asimismo, diversos manuales, guías o compendios (bandbooks) de lingüística publicados por prestigiosas editoriales contienen capítulos o abordan por completo aspectos de interés: en Paltridge - Starfield (eds.) (2013) se ofrece un completo panorama, de carácter cuasi-enciclopédico, con 28 capítulos y casi 600 páginas, sobre todas las áreas, aspectos pedagógicos y perspectivas metodológicas y de investigación sobre el inglés con fines específicos (llegando a incluir capítulos sobre el inglés de la aviación o el inglés para la enfermería, estudiado separado del inglés para fines médicos); por su parte, Hyland - Shaw (eds.) (2016) hacen lo propio, con 45 capítulos y casi 700 páginas, sobre el inglés para fines académicos. Por último, del trabajo dirigido por Lacorte (ed.) (2015) pueden aprovecharse para la materia que abordamos diversos capítulos, como los englobados en la parte III, «El español en las profesiones», o el 26. ${ }^{\circ}$, «Discurso académico y profesional», entre otros. 


\section{Referencias}

Aguirre Beltrán, Blanca (2004): «La enseñanza del español con fines profesionales», en Jesús Sánchez Lobato - Isabel Santos Gargallo (dirs.): Vademécum para la formación de profesores: Enseñar español como segunda lengua (L2)/lengua extranjera (LE), Madrid: SGEL, págs. 1109-1128.

Aguirre Beltrán, Blanca (2012): Aprendizaje y enseñanza de español con fines especificos: Comunicación en ámbitos académicos y profesionales, Madrid: SGEL.

Anthony, Laurence (2018): Introducing English for Specific Purposes, London New York: Routledge.

Calvi, Maria Vittoria (2006): Lengua y comunicación en el español del turismo, Madrid: Arco Libros.

Carabela, 44 (1998), número monográfico sobre La enseñanza del español como lengua extranjera con fines especificos [contiene bibliografia temática sobre la materia].

Gómez de Enterría, Josefa (2007): «La enseñanza del español con fines específicos», cap. 4. ${ }^{\circ}$ de Manel Lacorte (coord.): Lingüistica aplicada del español, Madrid: Arco Libros, págs. 149-181.

Gómez de Enterría Sánchez, Josefa (2009): El español lengua de especialidad: Enseñanza y aprendizaje, Madrid: Arco Libros.

Gómez de Enterría, Josefa (coord.) (2001): La enseñanza / aprendizaje del español con fines especificos, Madrid: Edinumen.

Gutiérrez Rodilla, Bertha (2005): El lenguaje de las ciencias, Madrid: Gredos.

Hernández Alonso, Néstor (2003): El lenguaje de las crónicas deportivas, Madrid: Cátedra.

Hutchinson, Tom - Alan Waters (1987): English for Specific Purposes: A Learning-Centred Approach, Cambridge - New York: Cambridge University Press. 
Hyland, Ken - Philip Shaw (eds.) (2016): The Routledge Handbook of English for Academic Purposes, Milton Park - New York: Routledge.

Lacorte, Manel (ed.) (2015): The Routledge Handbook of Hispanic Applied Linguistics, New York - London: Routledge.

Martín Peris, Ernesto (dir.) (2008): Diccionario de términos clave de ELE, Madrid: SGEL.

Neves, Ana C. (2020): Portuguese as an Additional Language, Cham, Suiza: Springer.

Paltridge, Brian - Sue Starfield (eds.) (2013): The Handbook of English for Specific Purposes, Malden - Oxford - Chichester: Wiley-Blackwell.

Regueiro Rodríguez, María Luisa (2014): La programación didáctica ELE: Pautas para el diseño de la programación de un curso ELE, Madrid: Arco Libros.

Regueiro Rodríguez, María Luisa (2016): Unidades, estrategias y técnicas didácticas en ELE, Madrid: Arco Libros.

Regueiro Rodríguez, María Luisa - Daniel M. Sáez Rivera (2013): El español académico: Guía práctica para la elaboración de textos académicos, $\mathrm{Ma}-$ drid: Arco Libros.

Sánchez-López, Lourdes (2010): «El español para fines específicos: La proliferación de programas creados para satisfacer las necesidades del siglo XXI», en Hispania, 93, 1, págs. 85-89.

Sánchez Pérez, Aquilino (1992): Historia de la enseñanza del español como lengua extranjera, Madrid: Sociedad General Española de Librería.

Santiago Guervós, Javier de - Jesús Fernández González (2017): Fundamentos para la enseñanza del español como 2/L, Madrid: Arco Libros. 
Suau Jiménez, Francisca (2010): La traducción especializada (en inglés y español en géneros de economía y empresa), Madrid: Arco Libros.

The Modern Language Journal, 96, especial 1 (2012), número monográfico sobre Language for Specific Purposes in the United States in a Global Context.

Vivanco Cervero, Verónica (2006): El español de la ciencia y la tecnología, Madrid: Arco Libros.

Widdowson, Henry G. (1983): Learning Purpose and Language Use, Oxford: Oxford University Press. 


\section{CAPITULO 13. OLHAR FONÉTICO-FONOLÓGICO NO DIALETO CAMBAECOLLANA FRONTEIRA BOLIVIA-RONDÔNIA}

Rosinete Vasconcelos Costa

\section{Introdução}

Em situação formal ou informal, a linguagem é definida pelo contexto de uso, como também pode ser determinada de acordo com o propósito de cada falante que pode, em situação diversa, selecionar os registros adequados que the vão permitir estabelecer as relações desejadas, podendo o emissor em um mesmo contexto mudar de registro com o intuito de estabelecer afinidade com o interlocutor ou modificar o tom ou o timbre da voz para enfatizar algum assunto.

Como as demais línguas, o espanhol apresenta diversas variações linguísticas que podem ser observadas tanto no espanhol europeu quanto no americano, cada uma com suas peculiaridades sem perder a unidade linguística existente entre elas.

Apresenta-se aqui um estudo linguístico que tem como objeto de pesquisa a análise dos processos fonético-fonológicos nos dialetos camba e colla ${ }^{2}$ do espanhol boliviano falado em Guayaramerín/Beni/Bolívia33 , fronteira com Guajará-Mirim/Rondônia/Brasil. Esses dois grupos linguísticos, camba e colla, ali convivem dividindo o mesmo espaço sociocultural, apesar de o ambiente linguístico predominante ser de área dialetal camba.

Este trabalho de carácter fonético-fonológico perpassa a dialetologia pelo fato de ser um estudo com dois grupos linguísticos (dialetos) que habitam numa

1 Segundo o "Diccionario de Lenguas y Dialectos del Mundo" online: camba significa "Dialecto del subgrupo tupi, guarani, perteneciente al grupo tupi-guarani, de la familia tupi hablado por tribus de Brasil y Venezuela."

2 E colla "Dialecto del subgrupo aimara, del grupo aru, de la familia quechumaran, hablado por tribus Bolivia y Perú." Idem, ibiden.

3 Esta pesquisa resultou do trabalho de campo da Dissertação de Mestrado em Linguística, que tem como título "A fala dos cambas e dos collas: processos fonético-fonológicos, realizada na Universidade Federal de Rondônia-UNIR, no campus de Guajará-Mirim. 
mesma área dialetal, porém conservando muitos dos traços próprios da região de origem, e, também, pela sociolinguística, por se estudar as variantes de fala realizadas nessa área, com seus respectivos falantes e seu estado sociocultural.

Neste artigo trataremos da análise dos fenômenos fonéticos dos segmentos vocálicos dos sons produzidos pelos informantes bolivianos em questão. Para tanto apresentamos as seguintes hipóteses em linhas gerais dentre as específicas: a) há ocorrência de diferentes fenômenos fonéticos nos dois grupos linguísticos; e) há possíveis interferências do português brasileiro, do quechua e do aymara nos dialetos camba e colla. Analisamos, então, a fala de dez informantes dos dialetos camba e colla, que convivem no mesmo ambiente linguístico, de diferente idade, sexo e grau de instrução, por serem fatores que contribuem para a diversidade linguística. Entretanto, para levantamento dos dados, utilizou-se do método da observação direta para reconhecimento do ambiente sociolinguístico, valorizando as pessoas e seus aspectos linguísticos e culturais, e de técnicas de entrevistas com perguntas despadronizadas, ou seja, abertas, diretas e espontâneas que foram surgindo durante a conversação, que foi gravada para posterior audição e transcrição do corpus.

$\mathrm{O}$ interesse por este estudo deu-se diante da necessidade de pesquisa em fonética na fronteira Guajará-Mirim-Brasil/Guayaramerín-Bolivia como material concreto para contribuição dos estudos linguísticos em fonética e fonologia e também para enriquecimento do currículo do curso de graduação de Letras/Espanhol da Universidade Federal de Rondônia, uma vez que não se constatou nenhum estudo fonético realizado em Guayaramerín ${ }^{4}$ que trate especificamente do tema em questão; o mais próximo foi em Riberalta realizado por Quilis para o "Atlas Linguístico de Hispanoamérica”.

Para a descrição dos segmentos fônicos, referente ao corpus linguístico, foram utilizados o Alfabeto Fonético Internacional-AFI e o quadro dos sons

4 Encontramos pesquisas com falantes de Guyaramerín em Guajará-Mirim, cf. BARBERY, Noely de Oliveira. O ecossistema lingüístico de Guajará-Mirim/RO: a fala dos imigrantes bolivianos e a hipótese da interlíngua. 96p. Dissertação (Mestrado em Lingüística) - Fundação Universidade Federal de Rondônia, Campus de Guajará-Mirim - UNIR, 2004, e FIRMINO, Bastos Ana Maria. A fala de imigrantes bolivianos em Guajará-Mirim/RO - Brasil: adaptação de um sistema fonético a outro. 92p. Dissertação (Mestrado em Lingüística) Fundação Universidade Federal de Rondônia, Campus de Guajará-Mirim - UNIR, 2005. 
do espanhol europeu constante em Quilis, no seu livro "Tratado de Fonología y Fonética Españolas", e, ainda, para constatação do contexto fônico fez-se uso da regra: $\mathrm{A} \rightarrow \mathrm{B} / \mathrm{C}-\mathrm{D}$.

Neste artigo, são apresentadas do corpus apenas algumas palavras ou expressões, em que se constatam os processos estudados, que fazem parte de um corpus maior, isto é, das entrevistas realizadas. Busca-se neste estudo mostrar o modo peculiar do espanhol falado em Guayaramerín, levando em conta tanto os fatores linguísticos quanto extralinguísticos, responsáveis pela variação na fala, ou seja, um quadro que represente linguisticamente essa comunidade de fala por meio dos processos fonético-fonológicos identificados.

A bibliografia principal utilizada para fundamentar esta pesquisa está baseada nos autores: Antonio Quilis, Tomás Navarro Tomás., Luiz Carlos Cagliari, Juan C. Zamora Munné e Jorge M. Guitart e López.

\section{Língua Espanhola - aspectos históricos e linguísticos}

O termo Espanhol para a língua espanhola sobrepõe-se ao termo Castelhano desde o século XVI por questão política. No entanto, os dois termos, castelhano e espanhol, são sinônimos e utilizados frequentemente pelos falantes espanhóis, mas do ponto de vista linguístico, segundo Mouton (1996, p.24) é preferível o termo espanhol já que representa o nome da nação, e castelhano, deveria ser usado para a variedade de Castela. Essa variedade, atualmente, resulta como afirma Zamora Munné e Guitart (1982, p.25) numa rede de dialetos historicamente aparentados e inteligíveis, com uma grande extensão geográfica. Assim, neste trabalho, utilizaremos o termo espanhol para denominar a língua aqui estudada, reiterando, também por ser o nome oficial desse idioma reconhecido internacionalmente.

A língua espanhola possui como base para a sua formação o latim, quando da colonização da "Hispania"s pelos romanos no século III a.C., mas não é possível definir uma data exata do seu surgimento, porque segundo Neto (1976, p.71): “Uma língua não dá à luz uma outra língua; nenhum linguista

5 Hispania era o nome dado, antigamente, à Península Ibérica e englobava diferentes províncias romanas. 
será capaz de fixar o momento do parto [...] é impossível marcar o momento em que o latim acaba e as línguas românicas começam.”

São muitos os falantes de espanhol, mas cada região tem sua maneira própria de falar, como afirma Quilis:

El español es una lengua de más de trescientos ochenta millones de hablantes, y cada uno de ellos posee su verdadero español. En amplias regiones o pequeños recintos, afloran hechos fonéticos que hay que conocer: unos son conservación de sonidos perdidos hace siglos en otras zonas; otros son la repetición de cambios acaecidos en épocas pretéritas de la historia de la lengua; los hay que siguen las directrices de determinadas evoluciones de las lenguas románicas, y algunos son el resultado de un cambio antes no observado. (Quilis, 1999, p.9):

Isto é, a variação linguística existente hoje no espanhol é resultado da evolução histórica, desde as línguas pré-romanas, ou de fatores extralinguísticos.

\section{A Língua Espanhola na América}

No século XV, com as navegações marítimas, deu-se início a colonização da América pelos europeus que buscavam comércio com as Índias, chegando à América no dia 12 de outubro de 1492. Neste ano começa o processo de colonização (bispanização $o^{6}$ linguístico e cultural da América. Apesar de Colombo estar acompanhado de dois intérpretes com amplos conhecimentos linguísticos, não foi fácil a comunicação com os nativos da região. Por tratar-se de línguas diferentes, tiveram, então, que comunicar-se pelos meios mais primitivos e universais, os gestos.

Conforme Quilis et al. (1987), como os indígenas resistiam ao novo idioma os missionários decidiram aprender a língua dos índios, com isto pensavam ser mais fácil evangelizá-los, mas de nada adiantava. Sem alternativa, começaram a ensinar-lhes línguas que achavam ser mais universais aos índios e davam-nas o nome de língua materna como o quechua, nabuatl, tupi-guarani e outras. Enquanto isso, as línguas indígenas ganhavam espaço e conseguiam

6 Termo utilizado pelos espanhóis. 
sobrepor-se como superstratos em grandes áreas territoriais, convivendo até hoje com o espanhol em várias regiões da América do Sul.

O espanhol chega à América no momento de transição do espanhol medieval ao espanhol atual, transplantando, aqui, suas incertezas fonéticas ou eliminando diversos regionalismos com a intenção de chegar a mudanças comuns. No entanto, na América cada região possui seu modo peculiar de falar, o mesmo ocorre com o espanhol europeu, pois são peculiaridades que não afetam a unidade linguística do idioma, já que os falantes desse idioma se entendem sem dificuldades.

A língua espanhola falada no continente americano chega juntamente com a colonização, da mesma forma como ocorre no Brasil, e passa a ser ensinada aos nativos que já tinham sua própria língua, como afirma Lapesa (1997, p. 356):

[...] en la constitución de la sociedad colonial tuvo cabida el elemento indígena, que, o bien aprendió la lengua española, modificándola en mayor o menor grado según los hábitos de la pronunciación nativa, o conservó sus idiomas originarios, con progresiva infiltración de hispanismos.

Daí a grande variedade linguística existente na fala dos hispanoamericanos até os dias atuais.

Segundo Quilis et al. (1987), os primeiros povoadores da América foram os andaluzes e canários que ali deixaram seu modo de falar, como também levaram consigo algumas variedades, sendo que ainda há muitas dessas variedades da época da colonização no espanhol andaluz, canário ou leonês.

Pela dificuldade da difusão do espanhol pelos europeus aos indígenas, esse idioma coexiste na América do Sul até hoje com línguas nativas, seja em caráter cooficial, como o quechua no Peru e Bolívia, aymara na Bolívia, ou oficial, como o guarani no Paraguai. São regiões bilíngues que sofrem influências linguísticas pelo contato que mantém com diversos grupos sociolinguísticos, além do contato fronteiriço no caso dos países da América Latina, que na sua maioria faz fronteira com o Brasil. Portanto, a fonética e o léxico no espanhol da América são bem diversificados. 


\section{Contexto histórico-linguístico Boliviano}

No século XV a Bolívia tornou-se parte do império Inca, posteriormente com a chegada dos espanhóis no século XVI foi incorporada ao vice-reino do Peru, e mais tarde ao de La Plata. Em 1809 o país começou a lutar pela sua independência, mas ainda ficou no poder da Espanha até 1825 quando foi libertada por Simón Bolívar, a quem o país deve o seu nome.

A Bolívia é um país da América do Sul que se limita ao norte e ao leste com o Brasil, ao sul com o Paraguai e a Argentina e a oeste com o Chile e o Peru. Politicamente está dividida em nove Departamentos: Pando, Beni, La Paz, Cochabamba, Oruro, Chuquisaca, Potosí, Tarija e Santa Cruz de la Sierra, que se subdividem em provincias responsáveis por alguns assuntos locais. Sucre é a capital da nação boliviana, sede do poder judicial, e La Paz a capital administrativa, onde se encontra a sede do governo geral.

O Beni é um departamento boliviano, que tem como capital Trinidad, e está situado no centro-norte da Bolívia, limitando-se ao sul com os Departamentos de Santa Cruz e Cochabamba, ao oeste com La Paz, ao nordeste com o Brasil e ao noroeste com o Departamento de Pando.

Segundo Vila (2000, p.169) a própria nação boliviana delimita o castelhano boliviano "[...] como variante dialectal del español", que se divide em três tipos de zonas dialetais "[...] determinados, en gran medida, por la influencia del sustrato, por el bilingüismo y por las consecuencias emergentes de las lenguas en contacto". Estas zonas se classificam em "A", "B" e "C". A que aqui nos interessa é a zona "B" formada pelos Estados do Pando, Beni e Santa Cruz, que leva o tipo: "castelhano camba" (nome do povoador nativo e da zona), é uma zona que se caracteriza pela influência das línguas da família tupi-guarani. Esta zona se subdivide em subzonas 1,2 e 3. Trataremos aqui da subzona 2 formada pela variedade camba do oriente. Esta subzona compreende o Departamento Beni, onde está localizada a cidade de Guayaramerín.

$\mathrm{Na}$ Bolívia se desenvolveram grandes civilizações indígenas, e como consequência enfrenta problemas culturais e raciais. Por outro lado, é um país 
de grande diversidade cultural e linguística, possui muitas influências incas e de outros povos indígenas na religião, na música, no vestuário e na língua, visto que além do idioma oficial, que é o espanhol, convive com outras línguas como o aymará, falado nos altiplanos, o quechua, falado nos vales e o tupi guarani, falado nas partes baixas, entre outros dialetos. Como afirma Vila (2000, p.169), "Esse abigarrado conjunto de hablas y tipos humanos -'collas', 'cambas' y 'chapacos' - más las etnias originarias, son, en síntesis, la nación boliviana." Porém, é um país com grande pobreza e baixos índices sociais, considerado um dos países mais pobres e menos desenvolvidos da América Latina.

\subsection{Guayaramerín}

Guayaramerín é uma cidade boliviana que pertence ao Departamento do Beni e está localizada à margem esquerda do rio Mamoré, limitando-se com o Brasil, fronteira com Guajará-Mirim, a $332 \mathrm{~km}$ de Porto Velho, capital do Estado de Rondônia. E a uma distância de $93 \mathrm{~km}$ de Riberalta e de $1.115 \mathrm{~km}$ de Trinidad e conta com uma população de 41.814 habitantes para o município de Guayaramerín, de acordo com o censo boliviano de 2012 (INE, 2012). Sua história começa com a exploração da borracha em Cachuela Esperanza. O primeiro nome que recebeu essa cidade foi "Puerto Palmira", depois mudado para Guayaramerín ${ }^{7}$ com a chegada de outros exploradores nos anos de 1893-1894. Guayaramerín/Bolívia e Guajará-Mirim/Brasil têm em comum o Rio Mamoré, que separa as duas cidades, meio pelo qual se cruza de um lado ao outro, além de empregar muita gente.

Para Guayaramerín, no início de sua formação, vieram pessoas dos mais variados lugares sob a promessa de enriquecimento rápido e retorno a seu lugar de origem. Ao chegarem no vilarejo se enfrentaram com difíceis situações, como ataque de nativos e dificuldades em navegar os rios, devido ao grande número de cachoeiras perigosas. Os que sobreviveram ali passaram a viver em conjunto com os demais moradores, formando assim uma nova cultura.

7 Que significa "cachuela chica", ou seja, "cachoeira pequena" em tupi-guarani. 


\subsubsection{Aspectos Sociolinguísticos de Guayaramerín}

Guayaramerín está habitada, principalmente, por dois grupos sociais conhecidos como colla e camba. Os collas são pessoas originárias da região andina, do ocidente boliviano, que mantêm suas tradições de vestimenta e penteado, enquanto os cambas são considerados mestiços descendentes de índios e europeus, esse termo também é utilizado como adjetivo pátrio para designar as pessoas do oriente boliviano.

O termo colla é derivado do nome que recebeu o território ocupado pelos Reinos Aymaras, que se chamava Collao, no Altiplano peruano-boliviano. Depois da conquista dos incas o território passou a ser chamado Collasuyu (a Província dos Collas).

Os collas, entre eles, falam quechua e aymara, porém com os demais falam espanhol, são bilíngues/trilíngues, sendo o espanhol sua segunda língua. Já os cambas falam um espanhol foneticamente diferente do espanhol dos collas, mais corrido, com aspiração ou perda do /s/ final de sílaba. No entanto, esses falantes dividem em Guayaramerín o mesmo ambiente geográfico e linguístico, ou seja, dois dialetos em contato, além do contato diário com o português do Brasil, através do comércio de mercadorias, por meio da fronteira, que acaba interferindo inconscientemente no falar dos habitantes dali.

Segundo Morales apud López (1997, p. 14-15):

Decimos que dos o más lenguas están en contacto cuando son usadas por los mismos individuos, es decir, cuando existe una situación de bilingüismo (o multilingüismo) en la que los hablantes bilingües constituyen el locus del contacto.

Além do preconceito linguístico que enfrentam os dois grupos devido às diferenças que há entre um falar e outro, também existe o preconceito social, fato que pudemos observar durante as entrevistas, inclusive com registro nas gravações.

Guayaramerín possui uma cultura diversificada, já que as pessoas que vivem ali são de diversos lugares do país, inclusive do Brasil. Portanto, não há 
uma cultura específica do lugar. A gastronomia, por exemplo, está composta por uma diversidade de pratos indígenas, europeus e outros.

\section{Questões Fonéticas e Fonológicas}

Ao comunicarem-se, os falantes utilizam uns elementos sonoros indispensáveis à comunicação na hora de distinguir uns significados de outros ${ }^{8}$. Tais elementos constituem a parte fônica do signo linguistico que se compõe de significante e significado ${ }^{9}$. O significante funciona em dois planos, no plano da língua como sistema de regras na organização do aspecto fônico (fonologia) e no plano da fala quando entra em ação o aparelho fonador por meio da articulação de alguns órgãos fisiológicos, produzindo uma corrente sonora que é perceptível ao ouvido (fonética).

De acordo com Quilis (2002), o homem quando fala emite sons que nem sempre são realizados igualmente por todos de um mesmo ambiente linguístico, e que nem sempre esses sons são os mesmos, nem apresentam o mesmo lugar de articulação, isto se justifica pelo contexto fônico em que se encontram, ou, ainda, por fatores extralinguísticos.

\subsection{O sistema vocálico do Espanhol}

Para a compreensão do estudo que segue, é importante entender as diferenças entre fonema, alofone e grafia ${ }^{10}$.

O fonema é a unidade mínima indivisível, distintiva, do signo linguístico, que não tem significado por si mesmo e é transcrito entre barras oblíquas $/ \mathrm{b} /{ }^{11}$. Já o alofone ou variante é a corrente sonora concreta que se produz na cavidade bucal pela transformação da voz, destinada à comunicação humana,

8 Os sons da fala nos três momentos da comunicação: emissão (fonética articulatória), transmissão (fonética acústica) e recepção (fonética perceptiva).

9 O significante é a expressão (palavra) e o significado o conceito, sentido, ideia (valor semântico), i.e, Signo Lingüístico=Significante + significado (Ferdinand de Saussure).

${ }^{10}$ É importante que não se confunda esses conceitos.

${ }^{11} \mathrm{O}$ fonema pode ser comutado, por exemplo, o fonema /b/ em /'bato/ e em /'beso/ pelo fonema /p/ em /'pato/ e em /'peso/ com mudança de significado. 
ou seja, é a realização de um fonema na cadeia falada. Transcreve-se entre colchetes $[\mathrm{b}]^{12}$. Enquanto que a grafia, ou letra, é a representação gráfica de um fonema na escrita, realiza-se por meio de signos ortográficos ${ }^{13}$.

Para o estudo e descrição de qualquer língua é necessário a coleta e transcrição dos dados que se precisa analisar, para isso se recorre a um alfabeto fonético/fonológico com o objetivo de representar de maneira clara e precisa as unidades fônicas da língua objeto de análise.

A seguir dispomos o repertório tradicional dos fonemas vocálicos do espanhol utilizados por Quilis (1999).

O sistema vocálico do espanhol consta de cinco fonemas, todos orais, porque segundo Quilis $(1997,1999,2002)$ e outros autores tradicionais da fonética e fonologia espanhola, não há fonemas nasais e sim alofones nasais dos fonemas vocálicos em distribuição complementar que se realizam de acordo com a ação do véu palatino.

\begin{tabular}{|c|c|c|c|c|c|}
\cline { 2 - 6 } \multicolumn{1}{c|}{} & \multicolumn{5}{c|}{ Sons Vocálicos do Espanhol } \\
\cline { 2 - 6 } \multicolumn{1}{c|}{} & \multicolumn{2}{|c|}{ Anterior } & Central & \multicolumn{2}{c|}{ Posterior } \\
\hline Alta & $\mathrm{i}$ & & & & $\mathrm{u}$ \\
\hline Media & & $\mathrm{e}$ & & $\mathrm{o}$ & \\
\hline Baixa & & & $\mathrm{a}$ & & \\
\hline
\end{tabular}

Quadro No1 - Fonemas vocálicos do espanhol Fonte: Dissertação de Mestrado, (Costa, 2007).

No espanhol há cinco fonemas vocálicos, que se dão tanto em posição átona como tônica, no início, no meio e no final de palavra, realizando-se com

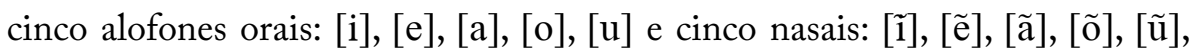
funcionando em distribuição complementar.

12 Enquanto o alofone mesmo que se pronuncie diferente não ocorre mudança de significado: [b] oclusiva em ['um 'beso] un beso e [ $\beta$ ] fricativa em [mi 'ßeso] mi beso, a diferença que existe entre estes sons é que o primeiro se dá depois de pausa ou consoante nasal, e o outro nos demais contextos. Ambos são alofones de /b/, ou seja, variantes de um mesmo fonema.

${ }^{13}$ Por exemplo, o fonema /b/ ortograficamente se escreve como "b" em beso. 
No espanhol, a nasalização de um fonema vocálico ocorre quando se encontra: a) entre duas consoantes nasais, b) depois de pausa e antes de consoante nasal, enquanto nos demais contextos em que aparece nasal o fonema vocálico realiza-se como oral, ou seja, não ocorre nasalização.

Quanto aos ditongos e tritongos, segundo Quilis:

Cuando los fonemas vocálicos /i, u/ no funcionan como núcleo silábico en un diptongo o en un triptongo, lo hacen como margen silábico, prenuclear o postnuclear. Para indicarlo, sólo desde el punto de vista fonético, se transcriben como $[\mathrm{j}, \mathrm{i}, \mathrm{w}, \mathrm{u}]$ y reciben tradicionalmente la denominación de semiconsonante ([j, w], margen prenuclear) o de semivocal ([i, u $]$, margen postnuclear). (Quilis, 1997, p.43).

As semiconsoantes $[\mathrm{j}, \mathrm{w}]$ ocorrem quando há um ditongo crescente, e as semivogais $[i \mathfrak{i}, \mathbf{u}]$ quando há ditongo decrescente.

De acordo com Tomás Navarro Tomás $(T N T)^{14}$ (1996), a língua espanhola apresenta diferenças importantes de pronúncia, não apenas entre os países que falam essa língua, mas também entre as regiões de um mesmo país, e inclusive em lugares de uma mesma região, pois ocorrem tanto no espanhol europeu quanto no americano, cada um com seu grau de variação.

\section{Metodologia}

Esta pesquisa, apesar de ser um estudo dos processos fonético-fonológicos de dois grupos linguísticos, dialetos camba e colla, que habitam um mesmo espaço geográfico e linguístico, porém diferentes no que diz respeito às características regionais, sociais, linguísticas e culturais, é impossível não abordar, mesmo que de forma indireta, aspectos da Dialetologia e da Sociolinguística, por estarem relacionadas entre si, já que os fenômenos fonéticos observados requerem uma análise mais substancial, considerando o que afirma Zamora Munné e Guitart:

Si la dialectología es horizontal y exige la consideración de diferencias regionales, la sociolingüística es esencialmente vertical, y las diferencias que

${ }^{14}$ A partir daqui apenas TNT como é usado pelos autores espanhóis. 
considera existen dentro de una región. Son ciencias que estudian fenómenos de naturaleza disímil, pero están lo suficientemente relacionadas como para que estudiar una, exija por lo menos aludir a la otra. (Zamora Munné e Guitart, 1982, p.24)

Além do contato entre esses dois dialetos há também o contato com falantes do português brasileiro, porque essa área territorial faz fronteira com o Brasil, podendo, portanto, esses dialetos sofrerem interferência deste idioma. Conforme aponta López:

Se suele hablar de interferencia/ transferencia o convergencia cuando una Lengua A comienza a mostrar signos (fonéticos, léxicos, gramaticales o sintácticos) que la alejan de las estructuras propias de su norma para tomar o asimilar estructuras propias de la lengua de contacto, es decir, de la Lengua B $[\rightarrow]$. (López,1997, p.14)

Os informantes que contribuíram para este trabalho são falantes dos dialetos camba e colla do espanhol boliviano falado em Guayaramerín, os quais foram selecionados por idade, sexo e grau de instrução. Informantes do sexo masculino e feminino, entre 17 e 41 anos, com nível de escolaridade primária, secundária e superior, por tratar-se de variáveis que intervêm no desenvolvimento da linguagem. Oito deles nascidos em Guayaramerín (cambas), dois destes filhos de colla ${ }^{15}$, enquanto os outros dois informantes nasceram em La Paz (collas).

Para facilitar o contato com os informantes para posterior entrevista, foi utilizado o método da observação direta, na qual o investigador se aproximou da comunidade inserindo-se no cotidiano da realidade investigada. Os contatos foram realizados no idioma espanhol com a intenção de obter confiança e de evitar interferências da língua portuguesa.

Os dados constam de um corpus coletado em 2004 e 2005, respectivamente, por meio de entrevistas diretas e espontâneas, gravado em gravadores do tipo digital (algumas entrevistas) e analógico, para comprovação e análise posterior dos sons realizados pelos informantes, o que possibilitou escutar a conversa várias vezes.

15 Também considerados camba por terem nascidos em ambiente camba. 


\section{Resultados da análise dos dados}

Os falantes dos dialetos camba e colla examinados neste trabalho têm em comum o idioma espanhol, o primeiro o tem como primeira língua e o outro como segunda língua, ambos adquiridos no próprio ambiente linguístico com as peculiaridades próprias inerentes à região de origem.

Da análise realizada destacamos abaixo alguns processos fonético-fonológicos observados na fala camba e colha na produção dos sons vocálicos. Para descrição desses processos utilizamos a seguinte regra, como regra geral, para informar os contextos em que se encontram a realização de determinado fonema: $\mathrm{A} \rightarrow \mathrm{B} / \mathrm{C}-\mathrm{D}$, que expressa que $\mathrm{A}$ é um fonema que se realiza como $\mathrm{B}$, que é um alofone, se ocorre no contexto em que esteja precedido de $\mathrm{C}$ (contexto precedente) e seguido de $\mathrm{D}$ (contexto subsequente). Porque segundo Cagliari:

A fala realiza-se através de uma cadeia de sons, produzindo um contínuo sonoro de qualidades variáveis ao longo do tempo. Um ambiente fonológico ou contexto é constituído por tudo o que precede ou segue um determinado segmento da fala. (Cagliari,1997, p.15)

Para a transcrição dos dados utilizamos a transcrição ampla, isto é, sem levar em conta detalhes de pronunciação que não dizem respeito à análise, uma vez que a atenção seria dada apenas aos sons mais perceptíveis aos processos em estudo.

Para a análise dos processos fonético-fonológicos na fala dos informantes, foram selecionadas palavras e expressões em diversos contextos fônicos, após a audição de um mínimo de três vezes, extraídas de conversações sobre temas diversos, principalmente sobre a história e a cultura do lugar e do país.

\subsection{Alguns processos fonético-fonológicos do sistema vocálico}

1- Monotongação

a) monotongação de hiato:

\section{Camba}

$$
\begin{aligned}
& \text { /koreogra'fia/ } \rightarrow \text { [korogra'fia }] \text { “coreografia” } \\
& 1 \text { o /e/ } \rightarrow[\varnothing] / \text { s }- \text { o } \quad \text { e } \quad 2^{\circ / e o / \rightarrow[0]}
\end{aligned}
$$


Observa-se aqui um caso de monotongação decorrente da queda da vogal /e/ do grupo /eo/ que formava hiato, que ao ser articulado por um informante camba perde-se essa vogal devido a uma tendência "anti-hiática" nesse grupo de falantes.

b) monotongação de ditongos:

\section{Camba}

$$
\begin{aligned}
& \text { /es'kuela/ } \rightarrow \text { [es'kwela] } \rightarrow \text { [e'kwela] } \rightarrow \text { [ekola }] \\
& / \text { treinta i 'tres/ } \rightarrow \text { ['treintai'tres }] \rightarrow \text { ['trintai trre] "trinta e três" } \\
& 1^{\mathrm{o}} / \mathrm{e} / \rightarrow[\varnothing] / \mathrm{u}-\$ 1 ; \mathrm{c}-\mathrm{i} \quad \text { e } \quad 2^{\circ} / \mathrm{ue}, \mathrm{ei} / \rightarrow[0, \mathrm{i}]
\end{aligned}
$$

No segundo caso, também realizado por informante camba, ocorreu na redução de alguns ditongos, principalmente naqueles relacionados à vintena ou trintena, em linguagem coloquial, que apagou a vogal /e/ transferindo suas características à semivogal $[\mathrm{i}, \mathrm{w}]$ que passam a vogais $[\mathrm{i}, \mathrm{o}]$, simplificando a estrutura silábica. Observamos que nesse processo a semiconsoante $[\mathrm{w}]$ transforma-se em /o/ no lugar de /u/ ao ser pronunciada a palavra "escuela", possivelmente por uma influência do português brasileiro, por se tratar de palavra comum às duas línguas.

Tais processos deram-se antes ou depois de consoantes líquidas tanto em hiatos com em ditongos, desfazendo-se, portanto, estes.

\section{2- Ditongação}

Contrário ao fenômeno da monotongação, ocorrem nos exemplos abaixo a ditongação, que acrescenta à estrutura silábica um fonema por meio do contato de vogais seja na queda de consoantes, na juntura de vocábulos terminados e iniciados em vogais, ou ainda por inserção vocálica (epêntese), fortalecendo os segmentos fônicos da sílaba.

a) Ditongação causada pela queda da C onset: 


\section{Camba}

/'medio/ $\rightarrow$ ['meðjo $\rightarrow$ ['me $\left.{ }^{\gamma \text { jo }}\right] \rightarrow$ ['meio $]$ "meio"

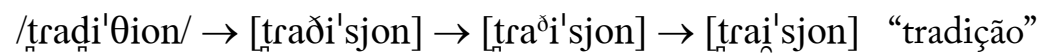

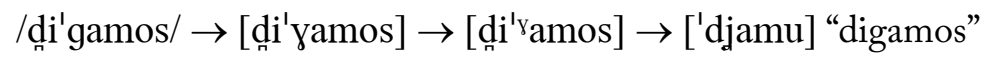

\section{Filha de colla}

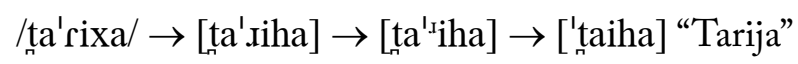

$/$ mis'tura/ $\rightarrow$ [mis'tura $] \rightarrow\left[\right.$ mis'tura $\left._{n}^{\prime}\right] \rightarrow$ [mih'twa ${ }_{\sim}^{\prime}$ "mistura”

$1^{\mathrm{o}} / \mathrm{d}, \mathrm{g}, \mathrm{f} / \rightarrow[\mathrm{\delta}, \mathrm{\gamma}, \mathrm{r}] \rightarrow\left[{ }^{\mathrm{\gamma}, \mathrm{\gamma}, \mathrm{r}}\right] \rightarrow[\varnothing] / \mathrm{V}-\mathrm{V} \quad$ e $\quad 2^{\circ} / \mathrm{i}, \mathrm{u} / \rightarrow[\mathrm{i}$, $\mathrm{j}, \mathrm{w}] / \mathrm{e}, \mathrm{a}-;-\mathrm{a}$

b) Ditongação causada pela queda da C coda em juntura intervocabular:

\section{Camba}

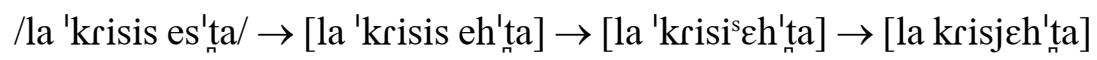
"a crise está"

$/$ per'dimos a'i $/ \rightarrow$ [per'ðimosa'i] $\rightarrow$ [perðimw $\left.{ }^{\mathrm{s}} \mathrm{l}^{\prime} \mathrm{i}\right] \rightarrow$ [perðimwa'i] "perdemos aî"

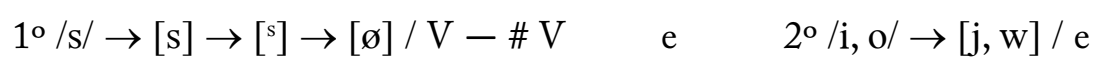

$-;-\mathrm{a}$

c) Ditongação causada pela queda da C coda e onset em juntura intervocabular:

\section{Camba}

/ga'nar di'nero/ $\rightarrow$ [ga'na. di'nero $] \rightarrow\left[\right.$ ga'na $^{ \pm}{ }^{\prime}{ }^{\prime}$ 'nero $] \rightarrow$ [ganaĩ'ner $]$ "ganhar dinheiro"

$1^{\mathrm{o}} / \mathrm{r}, \mathrm{d} / \mathrm{d} /[\mathrm{I}, \mathrm{\partial}] \rightarrow\left[{ }^{\mathrm{I}, \mathrm{\gamma}}\right] \rightarrow[\varnothing] / \mathrm{a}-\# ; \#-\mathrm{i} \quad$ e $\quad 2^{\mathrm{o} / \mathrm{i} /} \rightarrow[\mathrm{i}] / \mathrm{a}-$

Os processos de ditongação observados acima na fala camba e colla deram-se por meio a) do enfraquecimento e apagamento das fricativas [ð, $\mathrm{\gamma}]$, da 
nasal [n] e da vibrante simples [r], intervocálicas e de final de sílaba, onset e coda silábico, antes de palavra iniciada por vogal, por meio de juntura intervocabular

d) Ditongação causada por juntura vocálica intervocabular:

Colla

/'unos i 'otros/ $\rightarrow$ [un'sjotro]"uns e outros"

$/$ 'beinte 'anos/ $\rightarrow$ ['beĩn'tjãnu] "vinte anos"

\section{Camba}

/ttreinta i 'tres/ $\rightarrow$ ['trintai 'tre] "trinta e três" $/ \mathrm{i} / \rightarrow[\mathrm{j}, \mathrm{i}] / / \mathrm{o} ; \mathrm{a}-$

A ditongação, aqui, se deu pelo agrupamento do fonema/i/, correspondente à conjunção "y” entre vocábulos, que se realizou foneticamente como a semiconsoante [j] e como a semivogal [i] por estar entre uma consoante e uma vogal e uma vogal e uma consoante, respectivamente, agrupando-se silabicamente à vogal que o segue o precede, assim como ocorre com /e/ final de sílaba que se transforma em [j] ao juntar-se à vogal /a/ da palavra seguinte.

e) Ditongação causada por inserção vocálica:

\section{Camba}

/magda'lena/ $\rightarrow$ [mayða'lena] $\rightarrow$ [mair ðða'lena] “Madalena” ${ }^{16}$

Camba e Colla

/beinti'tres 'anos/ $\rightarrow$ [beintitre'hanjo] "vinte três anos"

/'tres 'anos a'tras/ $\rightarrow$ [trre'hanjua'trras] "três anos atrás"

\section{Colla}

/'muţas/ ['mũita ${ }^{\mathrm{h}}$ “'muita”
$1^{\mathrm{o}} / \varnothing / \rightarrow[\mathrm{i}, \mathrm{j}] / \mathrm{a}-\mathrm{g} \$ ; \mathrm{n}-\mathrm{o} ; \mathrm{u}-\mathrm{t}$

${ }_{16}$ Nome de rua e cidade boliviana. 
Nestas pronúncias a ditongação ocorre por inserção da vogal/i/ depois da palatal nasal/n/ e antes da fricativa / $/$ por conta do apagamento da oclusiva $/ \mathrm{t} /$ que formava o fonema $/ \mathrm{t} \mathrm{f}$, mudando, portanto, a estrutura silábica dessas palavras. Durante o processo de ditongação por juntura, as vogais /i, e, u/ perdem suas características e adquirem traços de semivogal e semiconsoante: /i/n, /j, w/, ao juntar-se com a vogal que assume o papel de tônica.

\section{3- Hiatização}

a) Hiatização por queda da C onset:

$$
\begin{aligned}
& / \mathrm{mer}^{\prime} \mathrm{kado} / \rightarrow \text { [mer'kao] "mercado" } \\
& / \text { ma'xado/ } \rightarrow \text { [ma'hao] "majado" } \\
& 1^{\mathrm{o}} / \mathrm{d} / / \rightarrow[\mathrm{\delta}] \rightarrow\left[^{\delta}\right] \rightarrow[\varnothing] / \mathrm{V}-\mathrm{V} \quad \text { e } \quad 2^{\circ} / \mathrm{a}, \mathrm{o} / \rightarrow[\mathrm{ao}] / \mathrm{k}, \mathrm{x}-;
\end{aligned}
$$

$/$ ke 'a afek'tadro/ $\rightarrow$ [kea:fe'taðo] "que afetou” /e, a/ $\rightarrow$ [ea]

Observamos que nos dialetos examinados às vezes ocorre a formação de hiato por queda da consoante onset de algumas palavras ou por juntura intervocabular, porém, não com a mesma frequência em que os ditongos acontecem, porque como já foi explicitado no espanhol em geral há uma tendência "anti-hiática".

\section{4- Mudança de timbre vocálico}

a) mudança de timbre vocálico causada pela glotalização e apagamento do /s/ coda silábico:

\section{Camba}

/'es 'um 'poko desorde'nado/ ${ }^{17} \rightarrow$ ['Ehũm'poko ðchorðe'naðo] “é um pouco desordenado"

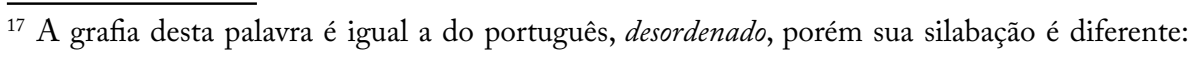


$/ \mathrm{e} / \rightarrow[\varepsilon]-\mathrm{h} ;-\#$

/'kosta 'markes/ $\rightarrow$ ['kohta 'ma:rke] "Costa Marques"

$/ \mathrm{o} / \rightarrow[\mathrm{o}] / \mathrm{h}-$

/te'niamos/ $\rightarrow$ [te'niamuh] "tínhamos”

/po'demos Ka'mar/ $\rightarrow$ [po'ðemu Ka'mar] "podemos chamar”

/no'sotros Ka'mamos/ $\rightarrow$ [no'sotro za'mãmu] "nós chamamos"

$/ \mathrm{o} / \rightarrow[\mathrm{u}] / \mathrm{N}-\mathrm{h}, \# \mathrm{C}, \#$

/tradii'siones/ $\rightarrow$ [traðisjo'ni] “tradições”

$/$ los 'xobenes/ $\rightarrow$ [lo 'hoßeni] "os jovens"

$/ \mathrm{e} / \rightarrow[\mathrm{i}] / \mathrm{N}-\#$

Os informantes cambas, ao pronunciarem a variante fricativa glotal [h], no interior e no final de palavra, no lugar da fricativa alveolar /s/ em coda silábica, tendem a produzir uma mudança de timbre nos fonemas vocálicos: /e/ e /o/, passando a realizá-los como variante aberta, [ع], [o], quando seguidos da fricativa glotal [h]. Este fenômeno também tem sido registrado por pesquisadores em outros dialetos, conforme literatura que trata do assunto.

Além da abertura vocálica, observamos também antes de glotal e precedida de nasal a ocorrência de vogal breve (fraca) no final de sílaba dos verbos da primeira pessoa do plural no paradigma da conjugação. Neste contexto faz-se referência à vogal /o/ que se comporta como [u] em: /te'niamos/ $\rightarrow$ [te'niamuh] "tínhamos". Porém, entende-se aqui que a mudança do timbre da vogal nesse contexto, ou seja, precedido de nasal $/ \mathrm{n} /$ ou $/ \mathrm{m} /$ está condicionada não pela realização glotal, mas sim pela nasal que precede essa vogal, porque esse fenômeno também ocorre em final absoluto de outras palavras, tanto com esse fonema como também com /e/ transformando-se em [i]: [1o 'xoßeni] "os jovens”, que se dá em ambos os dialetos. Para esse fenômeno levanta-se, portanto, as hipóteses de possível influência do português brasileiro ou dos dialetos quechua e aymara por terem em seu sistema fonológico apenas um fonema vocálico anterior e um posterior, ambos de articulação fechada, que são /i/ e foneticamente, em fala rápida, têm a mesma pronúncia. 
/u/, pois conforme Gordon (1968, p. 350), se alguns falantes de espanhol têm como língua materna um desses dialetos, mas não aprendeu bem o espanhol, podem confundir os sons dessas vogais.

b) mudança de timbre vocálico em ditongo seguido de aspiração e em juntura intervocabular:

Camba e filhos de colla

/'fiesta/ $\rightarrow$ ['fjehtra] "festa"

$/$ la 'krisis es'tta/ $\rightarrow$ [la krisjeh'ța] "a crise está”

$/$ per'dimos a'i/ $\rightarrow$ [perdimwa'i] "perdemos aî"

/majo'sia/ $\rightarrow$ [mo'ria] "maioria”

/e, o/ $\rightarrow[\varepsilon, \mathrm{w}] / \mathrm{i}-\mathrm{h} ; \mathrm{m}-$

A mudança de timbre vocálico pode também ocorrer nos ditongos crescentes com abertura da vogal, e nos decrescentes, como ocorre nos exemplos acima, em que o fonema /o/ enfraquece e realiza-se como uma semiconsoante [w], evitando hiato.

c) mudança de timbre vocálico antes e depois de líquida:

\section{Camba}

les'kuela/ $\rightarrow$ [es'kwela] $\rightarrow$ [e'kwela] "escola"

/el espa'nol/ $\rightarrow$ [Elehpa'nol] "o espanhol”

$/$ trans'porte/ $\rightarrow$ [tram'porte] "transporte"

/koreogra'fia/ $\rightarrow$ [kºrogra'fia] "coreografia”

/per'sona/ $\rightarrow$ [per'sona] "pessoa"

Colla e filha de colla

/inter'medio/ $\rightarrow$ [intrer'medjo] “intermediário"

$/$ kual'ker 'ora/ $\rightarrow$ [kwake'rora] "qualquer hora"

/e, o/ $\rightarrow[\varepsilon, 0] /-1 ;-$; $\mathrm{r}-$

d) mudança de timbre vocálico causada pela queda do // /:

Colla e filha de colla 
/'kinder/ $\rightarrow$ ['kind $\left.{ }_{n} \varepsilon\right]$ "pré-escola"

$/$ para kom'prar/ $\rightarrow$ [pa kom'pra] "para comprar”

le, $\mathrm{v} / \rightarrow[\varepsilon, \mathrm{a}] /-\#$;

O fenômeno da mudança de timbre vocálico não se trata de uma regra geral, mas uma tendência que já está bem estendida nos informantes desta pesquisa.

Além da mudança de timbre pelas realizações descritas anteriormente, as vogais /e/ e /o/ passam por um processo de abertura: [ $\varepsilon$ ], [०] quando seguidas de líquidas. Este mesmo processo ocorre com as vogais /a/ e /e/ que se abrem em final de sílaba pelo o apagamento da vibrante simples.

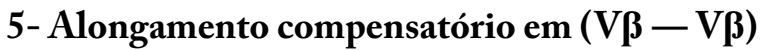

- alogamento por apagamento da $\mathrm{C}$ onset no interior de palavra e da $\mathrm{C}$ coda em sândi:

Camba e Filhos de colla

/alrede'dor/ $\rightarrow$ [are:'dor] "arredor"

len'tonses 'eKos/ $\rightarrow$ [eñ thonse:Koh] “então eles"

$/ \mathrm{ke}$ 'es 'el/ $\rightarrow$ [ke:'sel] "que é ele"

/'todo lo ke/ $\rightarrow$ ['to:lo ke] "tudo o que"

/seis i siete/ $\rightarrow$ [sei:sjete] "seis e sete"

/guajarame'sin/ $\rightarrow$ [guaja:me'sin] "Guayaramerín”

$/$ para a'riba/ $\rightarrow$ [pa:'rißa] "para cima”

/e, o, i, a/ $\rightarrow$ [e:, o:,i:, a: ] V $\beta-V \beta$

Nos exemplos acima ocorre alongamento [:] compensatório das vogais /o/, /e/, /i/ e /a/ pela queda das fricativas, [ð, j, s], e da vibrante simples, [r], em contexto intervocálico, no dialeto camba. Essas realizações deram-se pela fusão de vogais idênticas $(V \beta-V \beta)$ em contato, no meio de palavra e em juntura intervocabular, que fez com que uma delas se alongasse para compensar o espaço deixado pela consoante. Isto se dá porque na cadeia da fala quando uma palavra termina e outra inicia com o mesmo som, em espanhol geralmente, ocorre uma juntura, transformando estes sons em um único som. 


\section{6- Apagamento de vogais}

a) apagamento de vogais causado pela queda de consoantes intervocálicas:

Camba e filho de colla

$/$ majo'ria/ $\rightarrow$ [mº'ria $] \rightarrow$ [mo'ria $]$ "maioria"

$/$ todas esas 'kosas/ $\rightarrow$ ['toð ${ }_{n}^{\text {a' }}$ esah 'kosa $] \rightarrow$ ['toðesah 'kosa] "todas essas coisas"

$$
\begin{aligned}
& 1^{\mathrm{o} / \mathrm{j}, \mathrm{s} /} \rightarrow[\varnothing] / \mathrm{V}-\$ \mathrm{~V} \\
& 2^{\circ} / \mathrm{a} / \rightarrow\left[{ }^{\mathrm{a}}\right] \rightarrow[\varnothing] /-\mathrm{e}, \mathrm{o}
\end{aligned}
$$

Com a queda das fricativas /j, s/ intervocálica, no início e final de sílaba, respectivamente, a vogal /a/ que as precede é enfraquecida [a], apagando-se [ø] em seguida para evitar a realização de hiato. No segundo exemplo: /'todas esas 'kosas/ $\rightarrow$ ['toð ${ }_{n}^{\text {a' }}$ esah 'kosa] $\rightarrow$ ['toðesah 'kosa] “todas essas coisas”, observa-se que a coda silábica da primeira palavra se junta à palavra seguinte simplificando a estrutura silábica, o que também ocorre no outro exemplo com as vogais, porém no meio da palavra.

b) apagamento de vogais por síncope:

\section{Colla}

/'unos i 'otros/ $\rightarrow$ [un'sjotro] "uns e outros"

$$
/ \mathrm{o} / \rightarrow[\varnothing] / \mathrm{n}-\mathrm{s}
$$

No enunciado /'unos i 'otros/ $\rightarrow$ [un'sjotro] “uns e outros", em fala descontraída de uma informante colla de nível fundamental, observou-se o apagamento [ø] da vogal/o/ que precede o fonema /s/. A perda deste fonema se dá por meio do fenômeno de redução, no interior de palavra, chamado síncope, um processo não assimilatório, em decorrência da "lei de menor esforço" ou da hipótese de influência da língua portuguesa.

\section{7- Nasalização}

/eksatra'mente/ $\rightarrow$ [eksata'mẽnte] "exatamente" 


$$
\begin{aligned}
& / \text { 'mano/ } \rightarrow \text { ['mano] "mão" } \\
& / \mathrm{e} / \rightarrow[\tilde{\mathrm{e}}] / / \mid \$-\mathrm{N} ; \mathrm{N}-\mathrm{N} \\
& / \mathrm{a} / \rightarrow[\tilde{\mathrm{a}}] / \mathrm{N}-\mathrm{N}
\end{aligned}
$$

Nos dialetos camba e colla aqui analisados, observamos que além da realização normativa, nasalização por distribuição complementar quando a vogal se encontra precedida de pausa e de consoante nasal ou quando está entre duas consoantes nasais, os fonemas vocálicos /i/, /e/, /a/, /o/, /u/ também são nasalizados por assimilação regressiva ou progressiva.

a) nasalização por assimilação regressiva:

\section{Camba}

/ga'nar di'nero/ $\rightarrow$ [ganaĩiner] "ganhar dinheiro"

$/$ tam'bien/ $\rightarrow$ [tam'bjẽn] “também”

/a'blamos $/ \rightarrow$ [a'ßlamos] $\rightarrow$ [a'ßlamos $](\rightarrow$ [a'lãmu “falamos"

$/$ pan/ $\rightarrow$ ['pãy] "pão"

/'es 'un 'pan blan'kito/ $\rightarrow$ ['Ehũm'pãmblan'kito] “é um pão branquinho”

\section{Colla}

/'beinte 'anos/ $\rightarrow$ 'beĩn'țjãju] "vinte anos"

/en'tonses/ $\rightarrow$ [ẽn'ttõn: “então"

$/ \mathrm{i}, \mathrm{u}, \mathrm{a}, \mathrm{e} / \rightarrow[\tilde{1}, \tilde{\mathrm{u}}, \tilde{\mathrm{a}}, \tilde{\mathrm{e}}] /-\mathrm{N}$

$\mathrm{Na}$ expressão /ga'nar di'nero/ $\rightarrow$ [ganai'ner] "ganhar dinheiro" ao apagar-se a consoante $/ \mathrm{f} /$ coda e a $/ \mathrm{d} /$ onset da palavra que a segue, ocorreu a realização de um ditongo decrescente, por meio da juntura das vogais, com enfraquecimento da vogal /i/ da sílaba seguinte que passa à semivogal [i] nasalizada [ĩ] por assimilação regressiva à consoante nasal /n/. Ocorre também o mesmo processo de nasalização em outros exemplos acima na fala de informantes colla e camba.

b) nasalização por assimilação progressiva:

\section{Camba}

/'mismo/ $\rightarrow$ ['mĩhmo] “mesmo" 


\section{Colla}

$$
\begin{aligned}
& \text { /'mut Sas/ } \rightarrow \text { ['mũitah ] "muita” } \\
& \text { /'mano/ } \rightarrow \text { ['mãu] “mão" } \\
& / \text { te'nemos/ } \rightarrow \text { ['tẽemuh] "temos" } \\
& / \mathrm{i}, \mathrm{u}, \mathrm{a}, \mathrm{e} / \rightarrow[\tilde{\mathrm{i}}, \tilde{\mathrm{u}}, \tilde{\mathrm{a}}, \tilde{\mathrm{e}}] / \mathrm{N}-
\end{aligned}
$$

Nos demais exemplos a realização de nasalização progressiva das vogais /i/, /e/, /a/, /u/ ocorre por assimilação à consoante nasal /m/. Entretanto, na palavra /'mismo/ $\rightarrow$ ['mĩhmo] "mesmo" a nasalização não se dá em todos os informantes, ocorreu apenas em dois informantes camba como variante livre, pois às vezes nasaliza o / $\mathbf{i} /$ e outras vezes não. Enquanto em /'mut fas/ $\rightarrow$ ['mũita $\left.{ }^{\text {h}}\right]$ "muita" a nasalização do /u/ deu-se por conta da inserção do /i/ quando da queda do / $/$. E em /'mano/ $\rightarrow$ ['mãu] "mão" é mantida a realização nasal que já ocorria antes, ['mãno], mesmo com a queda da nasal seguinte /n/. As duas últimas realizações foram observadas na fala de um informante colla.

A nasalização progressiva e regressiva ocorre apenas em alguns informantes, em fala relaxada, não é uma constante.

Segundo Vegini (2006 p.5):

[...] a produtividade sempre renovada, ou seja, o dinamismo, a recursividade dos diversos processos fonológicos, os enfraquecedores e os fortalecedores [...] observada à luz dos processos fonoestilísticos (transformações fonéticas, a curto e médio prazos, e fonológicas a longo ou longuíssimo prazo) forma o pêndulo sobre o qual oscila a mudança histórica das línguas naturais e as mantém vivas.

Em resumo, após a análise dos dados, verificamos algumas realizações dos fonemas vocálicos do espanhol em Guyaramerín, conforme segue: /i/ $\rightarrow[\mathrm{i}, \mathrm{i}, \tilde{\mathrm{i}}, \mathrm{j}$,

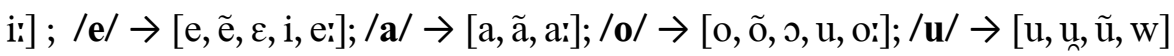

Considera-se, aqui, portanto, apenas as variações encontradas nos processos fonético-fonológicos perceptíveis, quando da análise das consoantes, por isto não fechamos aqui um quadro fonético-fonológico dos sons vocálicos 
realizados em Guayaramerín, por entendermos a necessidade de estudo e análise mais aprofundada de todas as vogais.

Segundo Cagliari (1997, p.36), "os diferentes usos - na fala - não é um aspecto estritamente fonológico (ou fonético), mas pragmático ou sociolinguístico". Já que existem outros fatores, ou seja, fatores além dos fonológicos, que dependem das circunstâncias em que se encontre o falante e como produz a fala em determinados contextos, levando ainda em consideração a idade, o sexo, o nível social e intelectual.

\section{Considerações finais}

A análise dos processos fonético-fonológicos nos dialetos camba e colla do espanhol boliviano falado em Guayaramerín, além de oferecer direcionamento para novas pesquisas nessa área, trouxe resultados significativos. Como se trata de importantes ocorrências fonéticas, na análise, procuramos estudá-las não somente observando os contextos em que ocorrem, mas também levando em conta a faixa etária e o grau de instrução dos informantes.

Além desses processos observamos interferência de um dialeto no outro, e levantamos algumas hipóteses de interferência do português brasileiro e dos dialetos "quechua" e "aymara" na fala analisada.

Como afirma López:

En muchas ocasiones, los hablantes no son conscientes - a veces ni remotamente - de que tal o cual palabra ha entrado en una de las dos lenguas mediante interferencia y, mucho menos, de que se trata de un término extranjero. Cuanto más parecidas sean las lenguas, menor probabilidad de identificación por parte de los hablantes. (López, 1997, p.14-15)

Registrou-se para as vogais um total de vinte realizações, entre orais e nasais, das quais cinco são fonemas orais e quinze são variantes desses fonemas, destas não se encontram na variedade culta do espanhol: as realizações alongadas, as vogais nasalizadas por assimilação, a realização dos fonemas /e/ como 
$[\mathrm{i}, \varepsilon]$ e /o/ como [u, o], como se realiza no português, além do apagamento de alguns sons que ocorre no sistema fonético vocálico do espanhol boliviano.

Acreditamos que os objetivos propostos para este trabalho foram desenvolvidos satisfatoriamente, e que as hipóteses apresentadas, em sua maioria, foram confirmadas, nos surpreendemos com o fato de as descobertas terem sido maiores do que supúnhamos.

Como se pode perceber na sucessão de variedades registradas no corpus analisado, que corresponde de maneira peculiar ao estilo próprio de seus falantes e à dinâmica própria da língua, possibilitando a mudança sem afetar o percurso da comunicação.

Portanto, por esta pesquisa possibilitar a abertura de caminhos para novos trabalhos, já que não se tem conhecimento de outro estudo a respeito do tema nessa localidade, merece então um estudo mais sistematizado das realizações fonéticas, assim como o estudo das hipóteses levantadas de interferência do português brasileiro nos dialetos camba e colla, do espanhol boliviano, falado em Guayaramerín.

\section{Referências}

ALVAR, M. (direc.) Manual de Dialectología Hispánica. Español de América. In: VILA, Carlos Coello. Bolivia. Barcelona: Ariel, 2000.

CAGLIARI, Luiz Carlos. Análise Fonológica: Introdução à teoria e à prática com especial destaque para o modelo fonêmico. Campinas: edição do autor, 1997. v.1.

GORDON, Alan M. Notas sobre la Fonética del Castellano en Bolivia. <http://cvc.cervantes.es/obref/aih/pdf/06/aih_06_1_090.pdf> Acesso em janeiro de 2007..

GRUPO DE CIENCLAS HUMANAS Y DEL LENGUAJE. Diccionario de Lenguas y Dialectos del Mundo. Madrid: <http://www.diccionariosdigitales. $\mathrm{com} />$ Acesso em fevereiro de 2007. 
LAPESA, Rafael. Historia de la Lengua Española. 9.ed. Madrid: Biblioteca Románica Hispánica. Gredos, 1997.

LÓPEZ, Javier Medina. Lenguas en Contacto. Cuadernos de lengua española. Madrid: Arco/libros, S.L., 1997.

MOUTON, Pilar García. Lenguas y Dialectos de España. Cuadernos de Lengua española. 2.ed. Madrid: Arco/libros, S.L., 1996.

NETO, Serafim da Silva. Introdução ao Estudo da Filologia Portuguesa. 2.ed. revista e ampliada por BECHARA, Evanildo e LIMA, Joran Pinto de. Rio de Janeiro: Grifo, 1996.

QUILIS, Antonio et al. Lengua Española: Filologia. 2.ed. Madrid: Universidad Nacional de educación a distancia. ELVA, S.A 1987.

QUILIS, Antonio. Tratado de Fonología y Fonética Españolas. 2.ed. Madrid: Biblioteca Románica Hispánica. Gredos, 1999.

.Principios de Fonología y Fonética Españolas. Cuadernos de lengua española. 4.ed. Madrid: Arco/libros, S.L., 2002.

.El Comentario Fonológico y Fonético de Textos. Teoría y práctica. 3.ed. Madrid: Madrid: Arco/libros, S.L., 1997.

TOMÁS, Navarro Tomás. Manual de Pronunciación Española: Textos universitarios. Madrid: CSIC, 1996.

VEGINI, V. Processos Fonológicos num Idioleto do Português Urbano de Joinville. < <ttp://64.233.169.104/search?q=cache:0dfQ2X2D8MgJ:www. letraseletras.ileel.ufu.br/include/getdoc.php\%3Fid\%3D361\%26article\%3D93\%26mode\%3Dpdf+Valdir+Vegini+fonoestil\%C3\%ADstica\&hl=pt-BR\&ct=clnk\&cd=1\&gl=br $>$ Acesso em junho de 2007.

ZAMORA MUNNÉ, Juan Clemente; GUITART, Jorge M. Dialectología Hispanoamericana: teoría - descripción - historia. Salamanca: Almar, S.A. 1982. 


\section{SOBRE OS AUTORES (AS)}

ADEMIR JUNIOR DE SOUZA PIRES: Mestrando em Estudos Literários no Programa de Pós-Graduação em Estudos Literários da Universidade Federal de Rondônia. Especialista em História e Cultura Afro Brasileira pelo Instituto Educacional Maris. Graduado em História pela Universidade Federal de Rondônia. Professor de História em Escolas Públicas de Porto Velho, Rondônia. Contato: ademir_jsp@hotmail.com

AROLDO JOSÉ ABREU PINTO: Doutor em Letras pela UNESP/Assis-SP. Docente do Programa de Pós-Graduação em Estudos Literários da Universidade do Estado do Mato Grosso/UNEMAT, Campus de Tangará da Serra-MT. Professor do Departamento de Letras, Campus da UNEMAT de Tangará da Serra-MT. e-mail: aroldoabreu@unemat.br. Este trabalho está inserido em um projeto mais amplo realizado junto ao acervo do escritor $\mathrm{Ri}$ cardo Ramos e denominado "Acervo de Ricardo Ramos: disponibilização e organização de 1975 - 1980”, financiado pela UNEMAT/PRPPG e Conselho Nacional de Desenvolvimento Científico e Tecnológico - CNPq - Brasil.

DJENANE ALVES DOS SANTOS: É graduada em Letras Espanhol e bacharel em Letras pela Universidade Federal de Rondônia-UNIR, possui Especialização em Filologia Espanhola e Mestrado em Letras pela mesma universidade e está cursando Doutorado em Linguística pela Universidade Estadual de Mato Grosso. É pesquisadora do Grupo de Estudos Linguísticos, Literários e Socioculturais - GELLSO.

ELTON EMANUEL BRITO CAVALCANTE: Graduado em Letras pela Universidade Federal de Rondônia; graduado em Direito pela UNIR; especialista em Metodologia e Didática do Ensino Superior - UNIRON e em Filologia Espanhola - UNIR; especialista em Direito pela Escola da Magistratura de Rondônia; e Mestre em Estudos Literários pela Universidade Federal de Rondônia. 
ERLÂNDIA RIBEIRO DA SILVA: Possui graduação em Letras Espanhol pela Universidade Federal de Rondônia (2018), mestrado em Estudos Literários pela Universidade Federal de Rondônia (2020) e é doutoranda do Programa de Pós Graduação em Letras da Universidade Federal do Espírito Santo (UFES). Pesquisa na área de Literaturas de língua portuguesa e hispânicas, atuando principalmente nos seguintes temas: literatura feminina, poesia e diários de escritoras. http://lattes.cnpq.br/5588375107631166

GRACIELLE MARQUES: Doutora (2016) em Literatura e Vida Social pela Universidade Estadual Paulista (UNESP/FCL/Assis). É Professora Adjunta na Universidade Federal de Rondônia (UNIR), atuando na graduação de Letras Espanhol e no Programa de Mestrado Acadêmico em Estudos Literários (PPGMEL/UNIR). Tem experiência na área de Letras, com ênfase em 259 Literatura Comparada (Brasileira e Hispânica). É membro do Grupo de Pesquisa Literatura, Cultura e Alteridade (LECCA/UNIR). http://lattes. cnpq. Br/0915904616017403.

HELIO RODRIGUES DA ROCHA: Doutor em Teoria e História Literária (UNICAMP) e pós-doutorado em História Social (UFRJ). Professor e pesquisador na Universidade Federal de Rondônia (UNIR). Contato: heliorocha@unir.br

JOÃO CARLOS PEREIRA COQUEIRO: Doutor em Ciência da Educação pela Universidade de Trás-os-Montes e Alto Douro (UTAD), Portugal; graduado em Direito pela Faculdade de Ciências Humanas e Letras de Rondônia (1995); tem experiência na área de Direito, com ênfase em Sociologia Jurídica. Contato: jccoqueiro@yahoo.com.br

JUAN HERNÁNDEZ-ORTEGA: Es profesor e investigador en lingüística. Posee Máster en Investigación en Lengua Española por la Universidad Complutense de Madrid (UCM), institución en que obtuvo sus títulos de licenciado en Filología Hispánica y licenciado en Filología Románica. Entre sus líneas de trabajo destacan la sintaxis descriptiva, la lingüística comparada 
románica, la gramática contrastiva español-portugués — con atención al sistema verbal y a los sistemas pronominales - y la lingüística aplicada al estudio del español como lengua extranjera. Ha dado clases de Lengua española en universidades de España, Portugal y Brasil. Contacto: juan.hernandez@ucm.es

JÚLIO CÉSAR BARRETO ROCHA: Professor Doutor da Universidade Federal de Rondônia (UNIR, Porto Velho), do Departamento de Letras Vernáculas, trabalhou neste ano de 2020-2021 sob os auspícios do Programa PROCAD Amazônia (CAPES). Líder do Grupo de Pesquisa Filologia e Modernidades. CV: http://lattes.cnpq.br/4396120026626861.

LILIANE LENZ DOS SANTOS: Doutoranda em Estudos Literários pela Universidade do Estado do Mato Grosso - UNEMAT, Campus Tangará da Serra-MT, PPGEL, Tangará da Serra, Mato Grosso, Brasil. Contato: lililenz10@hotmail.com

LUCIANA PITWAK MACHADO SILVA PRATES: Professora Efetiva do Curso de Letras Espanhol da UNIR; Líder do Grupo de Pesquisa TraLinC - Tradução, Línguas e Cultura e Pesquisadora no GELLSO - Grupo de Estudos Linguísticos, Literários e Socioculturais; Mestre em Ciências da Linguagem; Especialista em Filologia Espanhola; Especialista em Metodologia do Ensino Superior; Graduação em Letras Espanhol pela UNIR

MARIELA MAGALI ROMÁN GUTIÉRREZ: Profesora de Idiomas (español e inglés) en la Escuela de Español Wiracocha del Cusco, ha trabajado 14 años en la enseñanza de español para extranjeros a nivel básico, intermedio y avanzado, así como en la preparación para Exámenes DELE de diferentes niveles, español médico y científico, español financiero, historia peruana y latinoamericana, literatura peruana y latinoamericana entre otros; clases presenciales y clases online; también ha colaborado en la elaboración del libro de la escuela de español Wiracocha. 
MIRELLA NUNES GIRACCA: Doutora e Mestre em Estudos da Tradução pela Universidade Federal de Santa Catarina (UFSC). Graduada em Letras Língua Espanhola pela UFSC. Professora Adjunta na Universidade Federal de Rondônia (UNIR). Porto Velho. Líder do TraLinC, CNPq - UNIR

NÁDIA NELZIZA LOVERA DE FLORENTINO: Doutora em Letras pela Universidade Estadual Paulista "Júlio de Mesquita Filho" (UNESP). Professora adjunta da Universidade Federal de Rondônia, lotada no Departamento de Línguas Estrangeiras. Docente do Mestrado Acadêmico em Letras - UNIR. Membro do Grupo de Estudos Linguísticos, Literários e Socioculturais (GELLSO). Atua nas áreas de Ensino de língua estrangeira e Literatura. Atualmente cursa Pós-Doutorado em Estudos Literários na Universidade do Estado do Mato Grosso através do Programa PROCAD Amazônia (CAPES).Contato: nadianelziza@unir.br

ODETE BURGEILE: Possui graduação em Letras (Inglês e Português) pela Universidade Estadual de Maringá, Mestrado em Letras pela Universidade Federal do Paraná e Doutorado Europeu (modalidade "Doctorado Europeo”) em Filologia Inglesa. É líder do Grupo de Estudos Linguísticos, Literários e Socioculturais - GELLSO. ORCID: https://orcid.org/00000001-7170-8872. <patriciacarneiro@unir.br> ORCID: https://orcid. org/0000-0002-8651-5739.juliorocha@unir.br

PATRÍCIA HELENA DOS SANTOS CARNEIRO: Professora Doutora da Universidade Federal de Rondônia (UNIR, Porto Velho), do Departamento de Línguas Estrangeiras. Vice-líder do Grupo de Pesquisa Filologia e Modernidades. CV: http://lattes.cnpq.br/6716464779286243.

RENATAAPARECIDA IANESKO: Doutora em Letras/Estudos Linguísticos pela Universidade Federal do Mato Grosso do Sul. Mestre em Letras pela Universidade Federal de Rondônia. Especialista em Língua Inglesa pela 
Unipan/Uniban. Possui Licenciatura plena em Letras (Português/Inglês) pela Universidade Paranaense. É integrante do Grupo de Estudos Linguísticos, Literários e Socioculturais - GELLSO.

RENY GOMES MALDONADO: É professora do Departamento Acadêmico de Línguas Estrangeiras DALE/UNIR. Tem experiência na área de Letras, trabalha com ensino de língua espanhola, gramática contrastiva, didática de línguas, literaturas hispânicas. Fez doutorado em Estudos da Linguagem pela Universidade Federal do Rio Grande do Norte (UFRN). É tradutora juramentada e pesquisadora dos Grupos de Pesquisas Ponte Literária Hispano-brasileira (UFRN), e Estudos Linguísticos, Literários e Socioculturais - GELLSO (UNIR). Contato: renymaldonado@unir.br. http://lattes. cnpq.br/4085048832593221

ROSINETE VASCONCELOS COSTA: Professora efetiva da Fundação Universidade Federal de Rondônia-UNIR no Departamento de Línguas Estrangeiras. É Licenciada e Bacharel em Letras Espanhol - UNIR. Possui Especialização em Metodologia e Didática do Ensino Superior pela Faculdade de Educação de Porto Velho-UNIPEC e Especialização em Filologia Espanhola - UNIR. Possui Mestrado em Linguística - UNIR. É membro do grupo de pesquisa GELLSO, na área de ensino/aprendizagem de língua estrangeira. Contato: rosinete@unir.br

SAMUEL ANDERSON DE OLIVEIRA LIMA: Doutor (2013) em Estudos da Linguagem pela Universidade Federal do Rio Grande do Norte. Realizou estágio de pós-doutoramento na Universidade do Ceará (2019) com pesquisa na Universidade de Buenos Aires. Atualmente, é Professor Associado da UFRN e membro permanente do Programa de Pós-graduação em Estudos da Linguagem. Tem experiência na área de Educação, com ênfase no ensino de línguas e literaturas brasileira e espanhola. Coordena o Grupo de Pesquisa Ponte literária Hispano-brasileira. É autor de Gregório 
de Matos: do Barroco à antropofagia (2016) e Edifício de palavras: Gregório de Matos e seu corpus espanhol 258 (2017). É um dos organizadores de Colóquio Barroco IV (2017), Literatura hispânica em pauta (2018), Tradição e contemporaneidade no barroco hispano-americano (2020), além de autor de vários artigos sobre os temas de suas pesquisas.

TIAGO CARVALHO DA SILVA: Professor de Língua Espanhola, formado pela UNIR em 2017; Pós-graduando em Ensino de Língua Portuguesa e Literatura pelo IFRO. Atualmente é Professor de Língua Portuguesa e Espanhola em instituições de ensino particulares de Porto Velho, Rondônia. 


\section{放UNIR}

A Fundação Universidade Federal de Rondônia (UNIR) é uma instituição pública de ensino superior criada em 1982. Ao longo de aproximados 40 anos, as ações de ensino, pesquisa e extensão formaram profissionais qualificados para atuação em todas as esferas da sociedade e do mercado de trabalho. A partir do ano 2000, com o início da oferta de cursos de Pós-Graduação, essa ação foi sendo ampliada, sendo ofertados, atualmente, 24 mestrados e 04 doutorados, abrangendo diversas áreas do conhecimento e priorizando pesquisas atinentes às questões ambientais, sociais, educacionais, culturais, econômicas e geográficas da Amazônia e especialmente de Rondônia. Como política de apoio e fortalecimento à Pós-Graduação e à pesquisa na Universidade, a Pró-Reitoria de Pós-Graduação e Pesquisa (PROPESQ) instituiu a publicação de livros elaborados pelos programas de Pós-Graduação, como atividade de divulgação e compartilhamento dos resultados das pesquisas produzidas por pesquisadores desta Instituição, tendo a Editora da Universidade Federa de Rondônia (EDUFRO), como unidade sistematizadora de todas as produções. Dessa forma, esta coleção, composta por 13 livros elaborados cada um por um PPG da UNIR, apresenta temas e abordagens disciplinares e transdisciplinares, divulga os resultados das pesquisas elaboradas nessa Instituição e aproxima a UNIR das Instituições Estaduais, Municipais e de toda a Sociedade.

Maria Madalena de Aguiar Cavalcante - Diretora de Pós-Graduação Artur de Souza Moret - Pró-Reitor de Pós-Graduação e Pesquisa

O desafio da Fundação Universidade Federal de Rondônia no ensino de graduação e de Pós-Graduação nunca foi tão grande, principalmente a partir dos recursos cada vez menores. Nesta pandemia por covid-19, o desafio foi não parar e a Pós-Graduação da UNIR não parou: defesas de dissertações e teses tornaram-se on-line e as produções acadêmicas-científicas não cessaram. Estes 13 livros da Coleção Pós-Gradução são a demonstração de que o esforço para o crescimento e a consolidação se mantém firme e constante. O futuro da Pós-Graduação na UNIR é o resultado das ações articuladas entre todos os atores, com maior abertura para a sociedade e para os setores públicos e com um grande objetivo que nos motiva, o de contribuir na formação em excelência de professores e pesquisadores nos países limítrofes. Os resultados nos colocam em papel de destaque na Amazônia e é isso o que desejamos: ser uma Instituição pública e gratuita, com forte apoio da sociedade para a oferta de cursos e formações que promovam o Desenvolvimento Regional e Sustentável do Estado de Rondônia

Marcele Regina Nogueira Pereira - Reitora
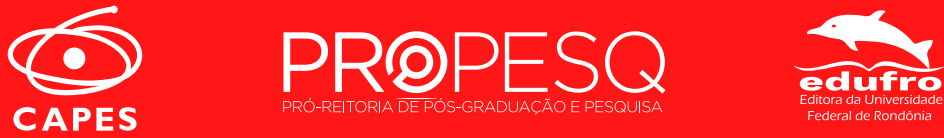